UNIVERSIDADE DE SÃO PAULO

ESCOLA DE COMUNICAÇÕES E ARTES

DAMYLER FERREIRA CUNHA

\title{
O som e as suas dimensões concretas e subjetivas nos filmes de Lucrecia Martel
}


DAMYLER FERREIRA CUNHA

\section{O som e as suas dimensões concretas e subjetivas nos filmes de Lucrecia Martel}

Dissertação apresentada à Escola de Comunicações e Artes da Universidade de São Paulo, para obtenção do Título de Mestre em Meios e Processos Audiovisuais.

Área de Concentração: Meios e Processos Audiovisuais

Orientador: Prof. Dr. Eduardo Simões dos Santos Mendes

São Paulo, 2013 
Autorizo a reprodução e divulgação total ou parcial deste trabalho, por qualquer meio convencional ou eletrônico, para fins de estudo e pesquisa, desde que citada a fonte.

Catalogação na Publicação

Serviço de Biblioteca e Documentação

Escola de Comunicações e Artes da Universidade de São Paulo

Dados fornecidos pelo(a) autor(a)

Cunha, Damyler Ferreira

O som e as suas dimensões concretas e subjetivas nos

filmes de Lucrecia Martel / Damyler Ferreira Cunha. -- São

Paulo : D. F. Cunha, 2013.

168 p.:il.

Dissertação (Mestrado) - Programa de Pós-Graduação em Meios

e Processos Audiovisuais - Escola de Comunicações e Artes /

Universidade de São Paulo.

Orientador: Dr. Eduardo Simões dos Santos Mendes.

Bibliografia

1. Poéticas e técnicas cinematográfica 2. Representação do som no cinema 3. Experiência da escuta acusmática 4. Lucrecia Martel I. Mendes, Eduardo Simões dos Santos II.

Título.

CDD 21. Ed. -791.43 


\title{
FOLHA DE APROVAÇÃO
}

Damyler Ferreira Cunha

O som e as suas dimensões concretas e subjetivas nos filmes de Lucrecia Martel

\author{
Dissertação apresentada à Escola de Comunicação \\ e Artes da Universidade de São Paulo para \\ obtenção do Título de Mestre. \\ Área de Concentração: Meios e Processos \\ Audiovisuais. \\ Linha de Pesquisa: Poéticas e Técnicas. \\ Orientador: Prof. Dr. Eduardo Simões dos Santos Mendes.
}

Aprovado em:

Banca examinadora:

Prof. Dr.

Instituição:

Assinatura:

Prof. Dr.

Instituição:

Assinatura:

Prof. Dr.

Instituição: Assinatura: 
À Patrícia, Miriam, Maria e Vanessa 


\section{AGRADECIMENTOS:}

Ao Prof. Dr. Eduardo Simões dos Santos Mendes, pela orientação atenciosa, lúcida, pela generosidade em partilhar sua sabedoria.

À Fundação de Amparo à Pesquisa do Estado de São Paulo, pela bolsa de mestrado concedida e pelo apoio financeiro para a realização desta pesquisa.

À Coordenação de Aperfeiçoamento de Pessoal de Nível Superior - CAPES, pela bolsa de mestrado concedida e pelo apoio financeiro para a realização desta pesquisa.

Às Professoras Dra. Suzana Reck Miranda e à Dra. Rosana Soares, pela bela leitura que fizeram da parte I da dissertação e pelas sábias observações e sugestões durante a qualificação, que ajudaram a aperfeiçoar este trabalho.

Pelo incentivo e material Lucreciano: Natalia Christofoletti Barrenha, Verônica Veloso, Beatriz Cruz, Gabriela Cordaro, Taty Kanter, Paulina Caon, Joaquim Lino, Kátia Lazarini, Miriam Rinaldi, Sandra Ximenez, Coletivo Dodecafônico e ao PH2 Estado de Teatro.

Pelo material eletroacústico e inspirações auditivas: ao grande mestre Murray Schafer, Giuliano Obici, Felipe Julián, Daniel Bolda, Bernardo Marquez, Dino Vicente, Fernando Iazzetta, Alê Fenerich, Louis Robin, Tiago Bittencourt, Missionário José, Leonardo Corrêa e Alexandre Marino.

Pelas aulas inesquecíveis, aos professores Dr. Eduardo Seincman, profa Dra. Heloísa de Araújo Duarte Valente, profa Dra. Patrícia Mourão, prof Dr. José Miguel Wisnik, prof Dr. Ismail Xavier e ao prof. Dr. Jorge Ramos do Ó.

Aos amigos e colegas de estudo: Luana Brant, Diogo Velasco, Layo Barros, Raoni Carvalho Gondim, Fernanda Rios, Evelyn Beschizza, Dante Nery, Júlia Landgraf Pupo, Kelly Sabino, Isabela Valente, Monica Iozzi, Mariana Rolón, Florence Rodrigues, Carolina Otsuka, Jussara Dias, Pedro Plaza, Reinaldo Cardenuto, Marcelo Prioste, Fábio Uchôa, Margarida Adamatti, Isabela Goulart, Tainah Rouche, Marina Takami, Kira Pereira, Tide Borges, Lali Kritiszysnki e Laura Carvalho. Ao apoio de sempre: Adriana, Sejana e Maria Eduarda Cecílio.

Gracias à Lucrecia Martel, Guido Berenblum e Maria Alché. 


\title{
RESUMO
}

\section{CUNHA, D. F. O som e as suas dimensões concretas e subjetivas nos filmes de Lucrecia} Martel. 2013. 168p. Dissertação

(Mestrado) - Escola de Comunicações e Artes, Universidade de São Paulo, São Paulo, 2013.

\begin{abstract}
A dissertação é dividida em duas partes. A primeira consiste em um estudo sobre a noção de escuta acusmática no cinema, levando em conta suas origens eletroacústicas e algumas de suas aplicações na ecologia acústica e na teoria cinematográfica. O enfoque privilegia as definições formuladas pelos teóricos, Pierre Schaeffer nos anos 50, Murray Schafer nos anos 70 e Michel Chion entre os anos 80 a 2000. A segunda parte da dissertação, mais fincada na análise fílmica, aborda alguns elementos da poética de Lucrecia Martel, dentre eles apontamos o uso do som para representação do tempo e de figurações do corpo. Designamos um conjunto de estados sensoriais e do pensamento como a fadiga, o cansaço, o esgotamento, o esquecimento e a inércia que ocupam um ponto importante em relação às análises dos filmes de Lucrecia Martel, apontadas por alguns críticos do cinema argentino.
\end{abstract}

Palavras-chave: escuta acusmática. Esquecimento. Poética de Lucrecia Martel.

\begin{abstract}
CUNHA, D. F. Sound and its concrete and subjective dimensions in Lucrecia Martel's films. 2013. 168 p. Dissertation
\end{abstract}

(Masters) - Escola de Comunicações e Artes, Universidade de São Paulo, São Paulo, 2013. The thesis is divided in two parts. The first one investigates the concept of acousmatic listening as applied to film practice, taking into account its eletroacoustic origins and some of its extensions to film theory and acoustic ecology. The approach privileges the definitions presented by theorists Pierre Schaeffer in the 1950s, Murray Schafer in the 70s and Michel Chion from the 80's to 2000. The second part, concentrated on film analysis, discusses some elements of Lucrecia Martel poetics, among which the use of sound is pointed out for representations of time and body figurations. A set of sensorial and thought states is designated, including fatigue, tiredness, exhaustion, forgetfulness and inertia, that play an important role regarding the analysis of Lucrecia Martel's films, as pointed out by some critics of the new Argentinean cinema.

Key words: Acousmatic listening. Forgetfulness. Lucrecia Martel's poetics. 


\section{LISTA DE ILUSTRAÇÕES}

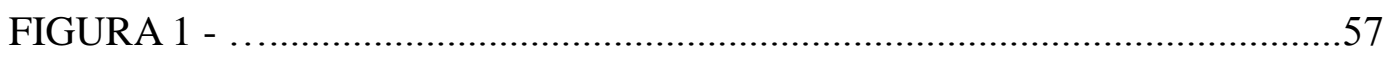

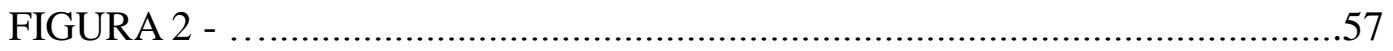

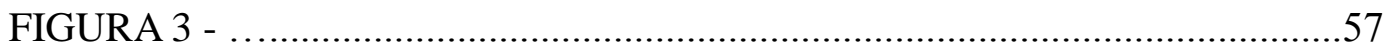

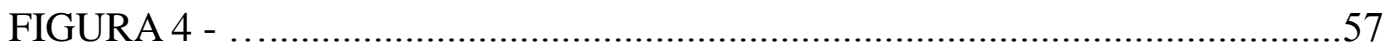

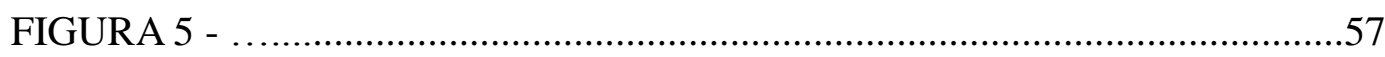

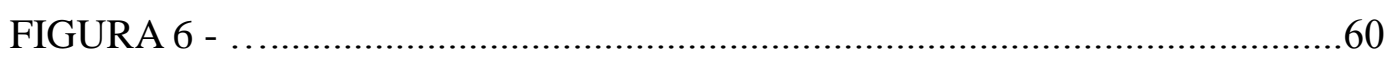

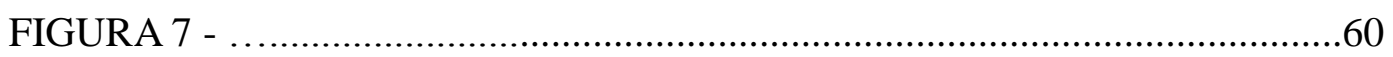

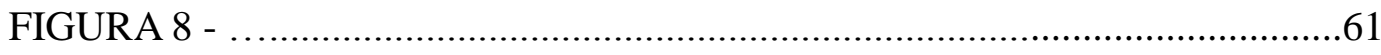

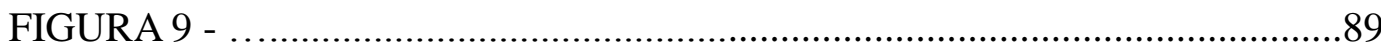

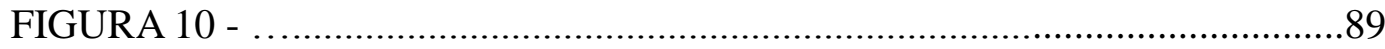

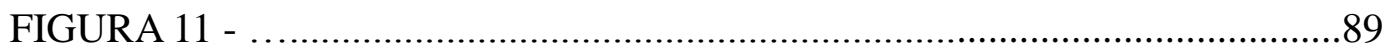

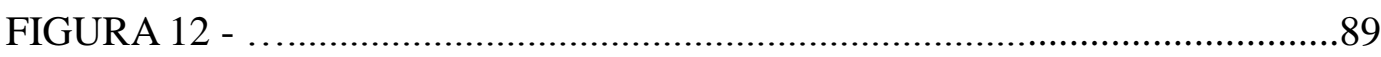

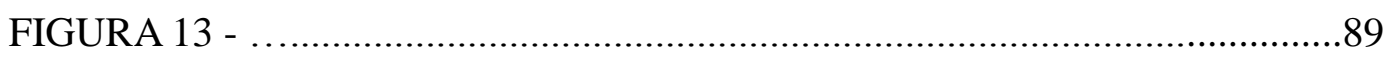

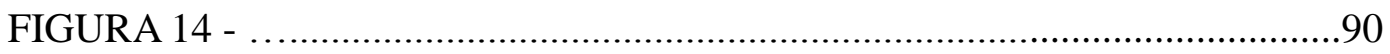

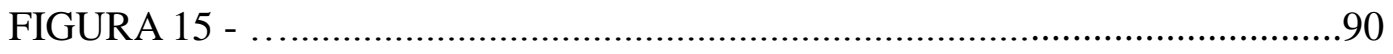

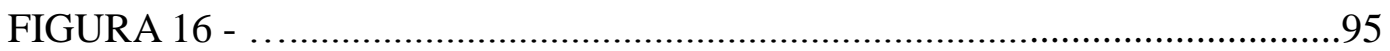

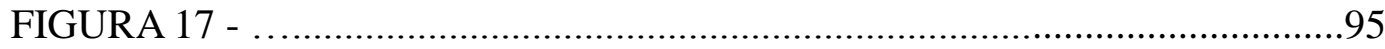

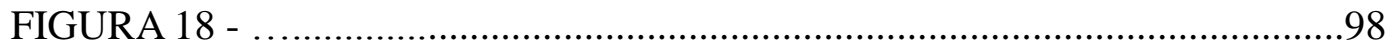

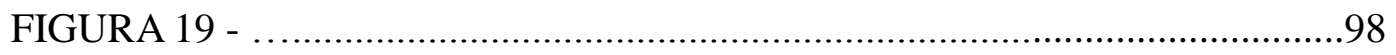

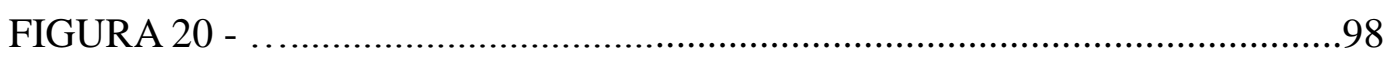

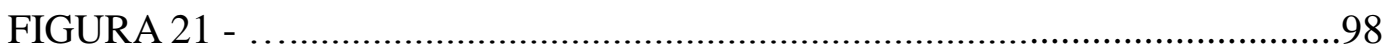

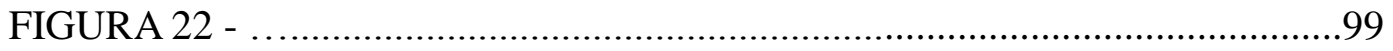

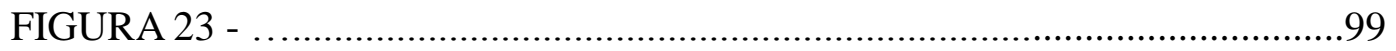

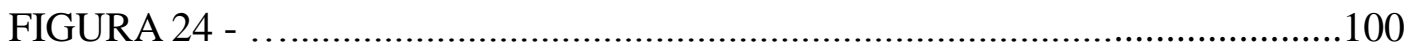

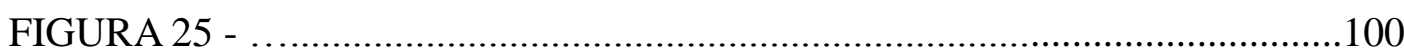

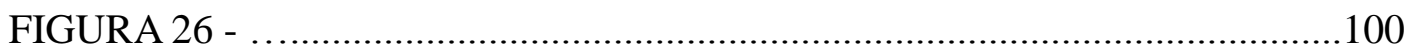

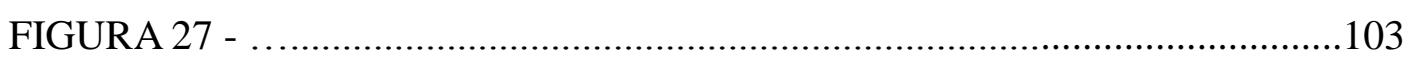

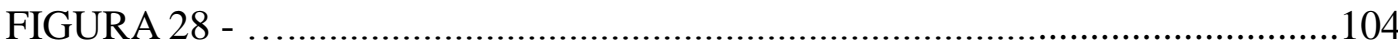




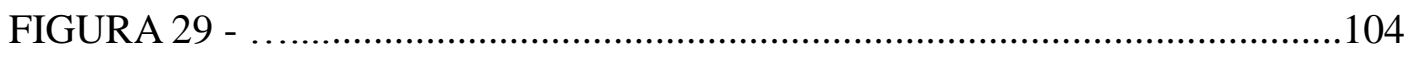

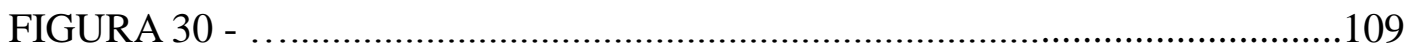

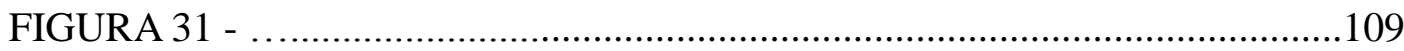

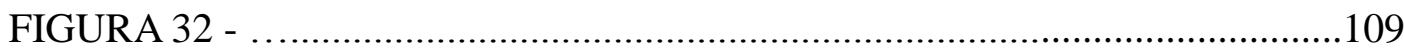

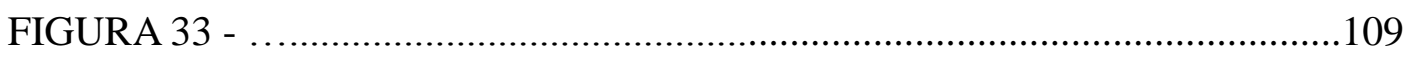

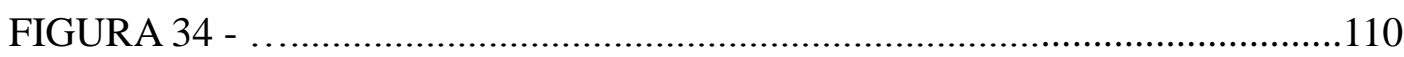

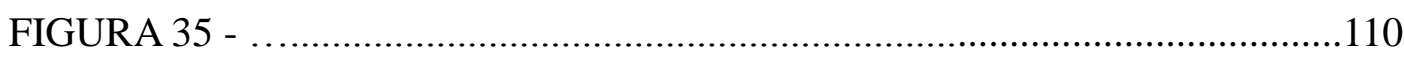

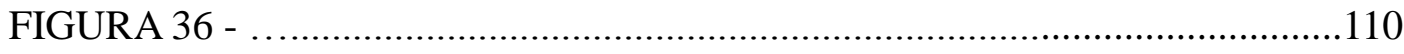

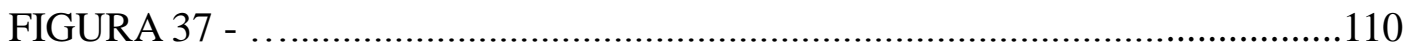

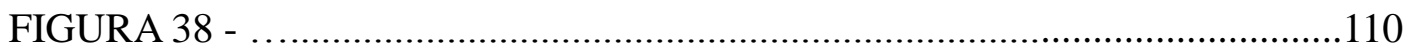

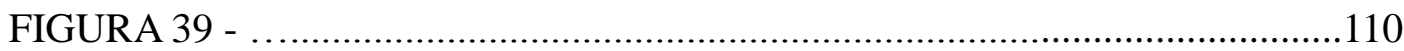

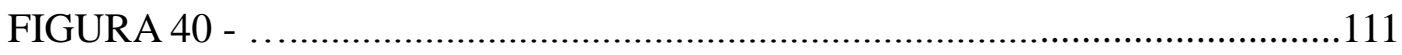

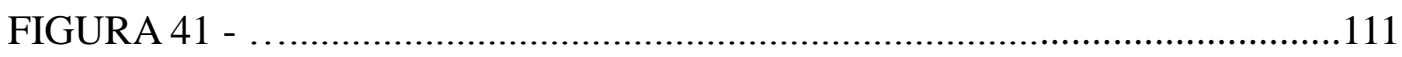

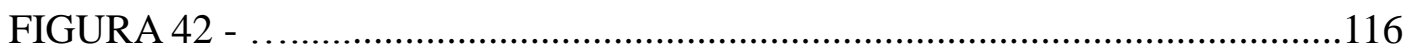

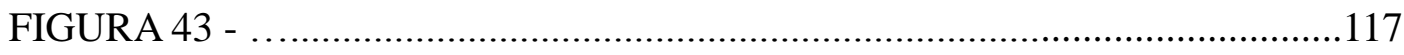

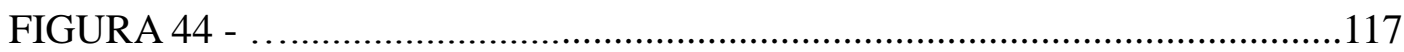

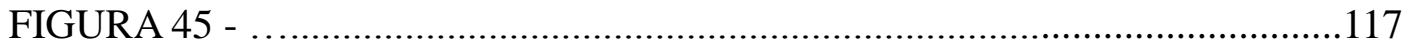

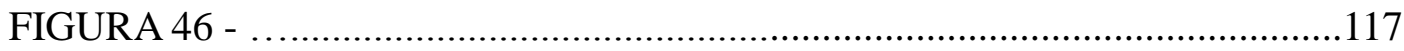

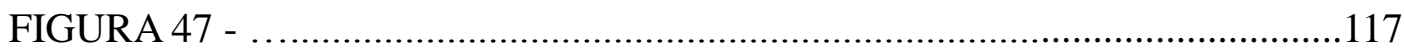

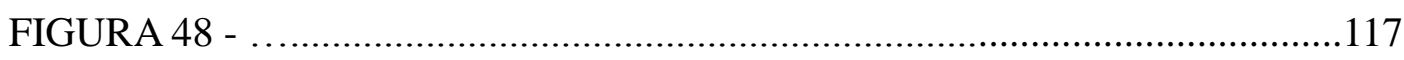

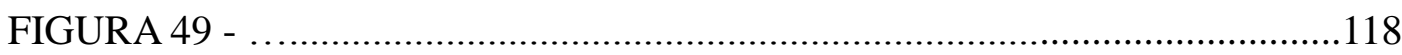

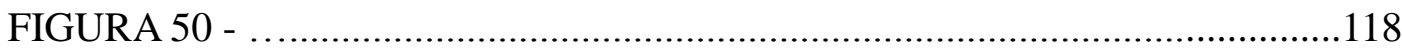

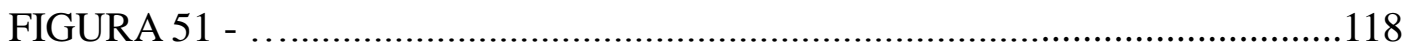

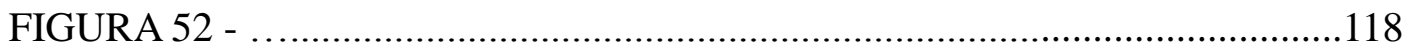

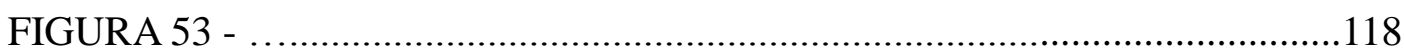

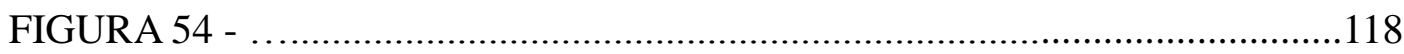

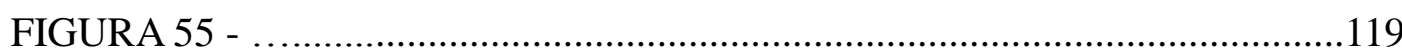




\section{SUMÁRIO:}

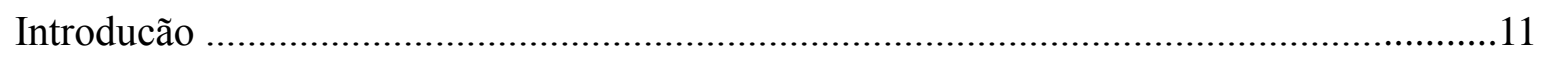

Parte 1 - As Dimensões Concretas e Subjetivas do Som

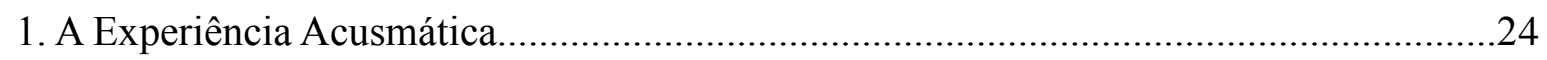

1.1. Uma apresentação de Lucrecia Martel ....................................................................24

1.2. Breve contexto histórico sobre a paisagem sonora: a experiência acusmática

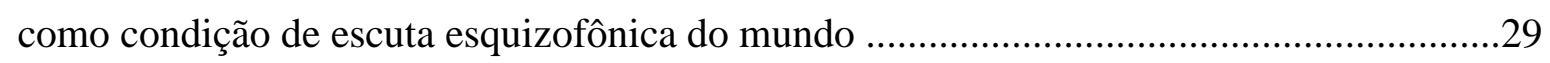

1.3. A experiência acusmática como subjetivação do som...................................................32

1.4. Deslocamentos, posições e trajetórias: a experiência acusmática no cinema.................38

1.4.1. A “escotomização" do ouvido-microfone no cinema.................................................43

1.4.2. Percepção bi-sensorial sonora: Co-Vibração e Janela Auditiva..................................45

2. O ouvido como instrumento de subjetivação do som nos filmes de Lucrecia Martel.......49

2.1.As práticas e as maneiras de incorporação dos sons.....................................................51

2.2. A representação de um modo de escuta contemporâneo.................................................54

2.3.A partilha da escuta entre espectador e personagens: um modo de aproximação............61

Parte 2 - A Casa de Lucrecia

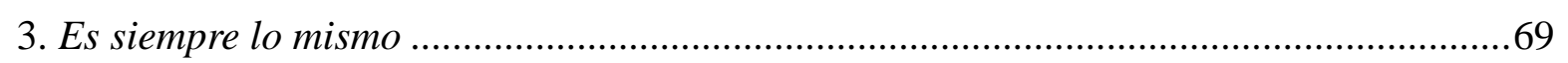

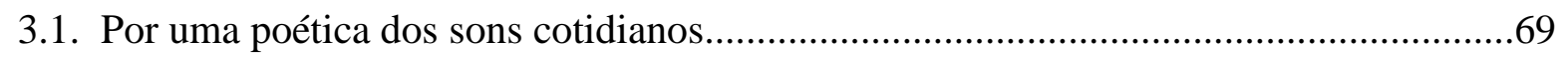

3. 2. O Nuevo cine argentino e suas figuras ficcionais contemporâneas................................76

3. 3. Sons fora-de-campo: elementos de perturbação na mise-en-scène.................................83

3.4. As pequenas subversões acidentais na casa, na piscina, no cerro e na estrada: os espaços rarefeitos e as cadências evitadas nos filmes de Lucrecia Martel.............................88

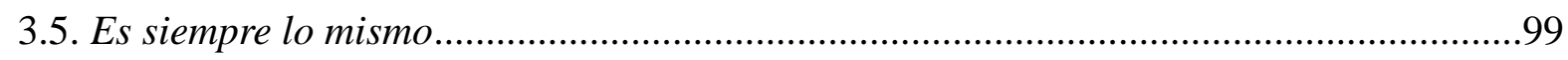

3.6. A interiorização da escuta: ponto de escuta subjetivos e atmosferas deliquescentes em

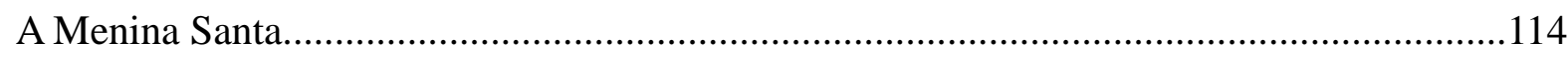

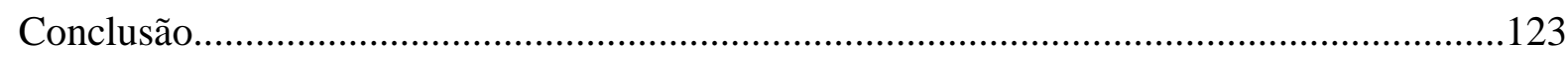

Anexos :

a) Entrevista com o diretor de som Guido Berenblum..................................................133

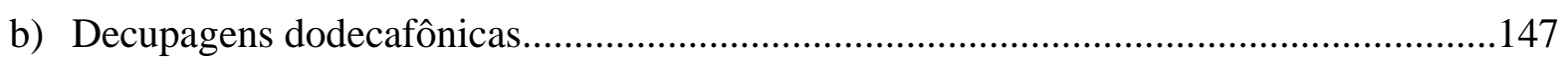




\section{INTRODUÇÃO}

O meu interesse em estudar os filmes da cineasta Lucrecia Martel surgiu, antes de tudo, de um impacto auditivo e sensorial ao assistir a alguns anos atrás o filme O Pântano ( $L a$ Ciénaga, 2001). Numa primeira impressão, estava ali, em forma sonora, atingindo os meus ouvidos, todo um pensamento sonoro contemporâneo sendo traduzido na representação de um modo de escuta dos personagens. Neste filme, vários eventos sonoros - acidentes dados somente pela escuta do seu som - aconteciam com o uso de ruídos que exercem a função de representar as emoções dos personagens e acontecimentos assombrosos. Assistindo ao filme novamente, a repetição de vários desses sons me soava estranhamente familiar. A insistência do uso de sons do cotidiano dos personagens como os telefones tocando, os latidos de cachorros, os estrondos provocados pelos trovões e o som de taças gerava um incômodo desconcertante; como se a presença contínua daqueles ruídos anunciasse uma destruição maior do que se via nas imagens.

Em $O$ Pântano, parece existir uma vontade de partilha da escuta na qual, espectadores e personagens, experimentam uma situação de escuta semelhante - ouvem-se sons que surgem como uma aparição inquietante e pelo susto que provocam, mudam a compreensão do sentido das imagens. Logo de início, os ouvintes deste filme compartilham uma atenção auditiva fortemente conduzida para percebermos os sons que se mantêm ocultos nas imagens, prestes a aparecer. Sons surgem do espaço fora de campo conferindo mais presença aos ambientes mostrados nas cenas que, porventura, adquirem sentidos simbólicos.

Estes dados se repetem nos três longas-metragens de Lucrecia Martel de distintas maneiras, formalizando uma poética da cineasta. Outras opções estéticas como a repetição 
ritualizada de sons e gestos cotidianos e o uso abundante de ruídos da instância diegética para composição da banda sonora demarcam uma questão pontuada desde seu primeiro longametragem: a espera. Ao conhecer os seus dois outros longas-metragens, A Menina Santa ( $\mathrm{La}$ Niña Santa, 2004) e A Mulher Sem Cabeça (La Mujer Sin Cabeza, 2008), a impressão inicial completou-se sob uma nova forma: na compreensão de que a questão da permanência das sensações através da intensificação e da representação da escuta seria a tônica de sua obra.

Conforme a análise que Hugo Ríos-Cordero (2008) aponta no artigo "La poética de los sentidos en los filmes de Lucrecia Martel”, a poética da cineasta consiste em determinadas práticas que privilegiam uma integração entre os diferentes sentidos na representação cinematográfica. Para Ríos-Cordero (2008), com uma maneira de aproximação ${ }^{1}$ única que ressalta a textura, o odor e o sabor das imagens, a cineasta estabelece uma relação audiovisual onde os domínios da visualidade são questionados pelos outros sentidos. Um modo de vision cercano - que se aproxima do detalhe dos corpos e dos objetos através da concentração de pessoas em espaços pequenos e do uso do desfoque da imagem - ressalta uma desorientação temporal no espectador e uma familiarização com a textura dos objetos (idem, ibidem, p.2). Preocupando-se mais em como promover os outros sentidos do corpo cinematográfico, a cineasta emprega certo olhar minimalista através das imagens e dos sons que se detém sobre as texturas e os volumes de objetos e personagens. Cria tempos de pausas ao voltar-se para os detalhes dos corpos fixando-se na frente dos reflexos de espelhos, janelas e portas. Também coloca em evidência as zonas sombrias dos planos por onde passam finos feixes de luz com o intuito de criar diferentes planos espaciais dentro dos enquadramentos.

Ao assistir os filmes de Martel, as imagens dos detalhes destes corpos demasiadamente próximos e assombrados pela escuridão dos cômodos das casas, assim como

\footnotetext{
${ }^{1} \mathrm{O}$ autor utiliza o termo em espanhol manera de acercase que, no decorrer desta dissertação, será retomado pelo diretor de som dos filmes de Lucrecia Martel, Guido Berenblum, como um modo único da cineasta de utilizar o som na sua mise-en-scène.
} 
os sons escutados, também provocavam uma estranheza em mim. Personagens ensimesmados compartilhavam suas intimidades um pouco incomodados. Seus beijos, os sustos, as crises, as quedas, as mortes e outras experiências vividas apareciam na tela dotadas de certa ambiguidade, mesclando uma sensação de familiaridade amistosa com algo ameaçador que precisa ser mantido longe do nosso olhar.

Alguns anos depois, ouvindo as composições concretas e lendo sobre os parâmetros eletroacústicos me ocorreu um pensamento: os sons que me tocaram ao assistir este filme só me impactaram desse modo, porque carregavam consigo um poder ambíguo. Escondidos da visão dos personagens e dos espectadores, os ruídos banais, de uso cotidiano, incitavam um jogo entre a busca pelo reconhecimento da sua causa e o afastamento do seu significado. Sons diegéticos que, aparentemente, só eram usados para conferir presença às cenas, sofriam metamorfoses quando se distanciavam da nossa visão para retornar à tela adquirindo sentidos mais trágicos na vida daqueles personagens. $\mathrm{O}$ som das taças quebrando representava os mesmos valores da sua imagem (CHION, 1999; 2011), mas também apresentava uma suspensão no tempo deste filme - breve momento no qual o som adquire a função de representar os pensamentos, as emoções ou as sensações experimentadas pelos personagens. Os sons das taças de vinho, a sua estridência incômoda, também representava o enclausuramento de Mecha naquela situação familiar. A partir de uma representação mental deste som, o corpo e o pensamento daquela personagem estavam aprisionados dentro daquela taça de vinho para mim, impedindo-a de reagir aos acontecimentos sugeridos nas imagens. A todo o momento que escutava novamente aquele som numa outra cena, me ocorria a lembrança do acidente vivido por Mecha como a concretização de seu destino imutável.

A partir desta constatação e de outras lembranças sonoras deste filme, as comparações com o modo de escuta e composição da música eletroacústica e concreta de Pierre Schaeffer foram inevitáveis, apesar de pouco diretas, através da evidência de similaridades entre as 
práticas de produção e organização dos sons. No período da Segunda Guerra Mundial, novas técnicas modificaram os suportes de reprodução sonora e os formatos fonográficos difundidos pelas mídias. Dentre estas novas técnicas, destacamos o uso de gravadores magnéticos e microfones que possibilitaram a experiência de gravação de sons domésticos, causando grande impacto na cultura fonográfica. Além da possibilidade de gravações não-profissionais, o surgimento de gravadores de fita magnética chegam às rádios e substituem os toca-discos nos procedimentos de realização das obras musicais. A música eletroacústica surge neste contexto, com a experimentação de sons por meio da variação de velocidade ou de sentido de leituras realizados pelo músico e radialista Pierre Schaeffer na RTF (RadiodiffusionTélévision Française) em 1948. Neste período, as suas experiências musicais ganham força e Pierre Schaeffer passa a nomeá-la como música concreta, em oposição a uma concepção tradicional da música que partia de abstrações sonoras pré-concebidas (para Schaeffer, o sistema de notação em partitura). Após a criação de um Grupo de Pesquisa sobre a Música Concreta (GRMC - Groupe de Recherche de Musique Concrète) em 1951, Pierre Schaeffer vê-se diante à necessidade de reafirmar e sistematizar as suas ideias dentro de um panorama de experimentações estéticas que aconteciam naquele contexto. Em 1966, publica o "Traité des objets musicaux" e estabelece 33 critérios de classificação da música concreta divididos em três dimensões fundamentais do fenômeno sonoro: o plano harmônico, o plano dinâmico e o plano melódico ${ }^{2}$.

Contudo, o título desta pesquisa "O Som e as suas dimensões concretas e subjetivas

\footnotetext{
2 Neste livro, continuando a formalização dos seus estudos apontados no ensaio "Esquisse d'un solfège concret" (1952), Schaeffer apresenta como proposta a substituição dos parâmetros tradicionais de altura, intensidade e duração. Para Schaeffer, os meios eletroacústicos possibilitaram a manipulação de notas que ultrapassavam as características das notas "instrumentais". Com a possibilidade da gravação dos ruídos e da sua incorporação em composições musicais, os componentes harmônicos não se mantinham proporcionalmente constantes - como é o caso do som tradicionalmente musical - e variavam ao acaso, não mantendo uma altura definida. Denominando o ruído como uma "nota complexa", Schaeffer propõe a substituição destes parâmetros tradicionais pela análise perceptiva do som enquanto três planos referenciais ou três dimensões sonoras: o plano das formas ou plano dinâmico, que é o plano de evolução dos níveis em decibéis em função do tempo; o plano harmônico, que é o plano dos níveis em função da altura; e o plano melódico, o plano das variações de altura em função do tempo (SCHAEFFER, 1952, p. 212).
} 
nos filmes de Lucrecia Martel” surgiu de outras características em relação ao som apontadas pelo músico concreto que são encontradas nos filmes desta cineasta. Em "Traité des Objtes Musicaux"”, Schaeffer (1966) trabalha com a dimensão estética do som na composição musical que parte de um som representado o tempo todo, já que os sons são transformados pela técnica e mediados através de dispositivos sonoros. Além de uma dimensão estética, o som também é compreendido a partir de uma dualidade paradoxal na poética concreta: faz-se externo atravessando o espaço objetivo (é físico, concreto), e, é ouvido através da subjetivação do som, passando pelo corpo daquele que escuta.

É a partir desta ambiguidade sonora que nos aproximamos dos parâmetros estéticos da música concreta para discutir o som no universo do cinema. O que se escuta? Os personagens ouvem conscientes ou inconscientemente os sons? Os sons fora de campo constituem sons ambientes, cujas fontes sonoras não fazem parte diretamente das narrações ou são usados pontualmente para representar acontecimentos e emoções? Nos filmes de Lucrecia Martel, a representação do som funde-se entre um fenômeno concreto, onde o som surge como a "causa" de sensações sonoras; e um fenômeno subjetivo, porque o som é revelado como não existente fora do corpo dos personagens, e por isso, dependente da sua subjetividade.

Através da transposição de uma tipo-morfologia da música concreta adaptada para a teoria cinematográfica por Michel Chion (Audiovisão, 2011), utilizamos alguns conceitos e parâmetros estéticos schaefferianos com o intuito de promover uma reflexão sobre as dimensões concretas e subjetivas do som nos filmes de Lucrecia Martel. O som fora-decampo para Chion (2011) é descrito como um som no qual sua fonte sonora não é visível na tela, mas que faz parte do espaço-tempo da ficção. Estes sons fora-de-campo podem ser usados para marcar um lugar com a sua presença contínua, exercendo um ponto de vista

\footnotetext{
${ }^{3}$ Ao longo desta dissertação vamos nos referir as pesquisas de Pierre Schaeffer apontadas neste livro. Contudo, nas citações usamos como referência a versão em espanhol "Tratado de los Objetos Musicales". Alianza Editorial, 1988.
} 
geográfico, topológico e espacial nas narrativas ficcionais; ou podem corresponder ao interior físico ou mental de um personagem (sons internos subjetivos e objetivos); ou mesmo incitar questões que procuram a sua resposta nas imagens, alimentando a expectativa dos espectadores (som acusmáticos, fora-de-campo ativo).

As diversas tipologias do som usadas pelo autor em "Audiovisão" (2011) são adotadas nesta dissertação a partir das exceções às regras estabelecidas para classificação do som no cinema. Considerando as categorias a partir de zonas e regiões entre as quais o som torna-se ambíguo, Chion abarca uma multiplicidade de sentidos e temporalidades representadas nos filmes a partir de suas próprias lógicas internas. Ao longo desta dissertação, vamos constatar nos filmes de Lucrecia Martel, a presença de três sons fora-de-campo que são usados para impulsionar as suas narrativas: latidos de um cachorro ( $O$ Pântano), a melodia de um theremin (A Menina Santa) e discretos e ritmados silvos (A Mulher Sem Cabeça). Assim como estes sons, muitos outros se tornam acusmatizados (saem do campo de visão do espectador) ou são desacusmatizados (entram no campo de visão) ao longo dos filmes. Contendo uma dupla-pertença, os sons acusmatizados perdem a referencialidade em um momento da narrativa para criar expectativas em relação à imagem da sua fonte sonora causal, conferindo uma marca misteriosa aos ambientes visualizados nas cenas.

No primeiro capítulo desta dissertação, nos deparamos com o pensamento sonoro da cineasta e as suas primeiras iniciativas realizadas para concretizá-lo em obras fílmicas. A partir da observação de uma puesta en escena ${ }^{4}$ sonora presente nas conversações familiares escutadas por Lucrecia Martel e nos contos orais contados pela sua avó nas horas de siesta, nos detemos sobre os pensamentos da cineasta acerca do som. Numa rápida abordagem biográfica, apresentamos algumas premissas do trabalho da cineasta e a evolução da produção

\footnotetext{
${ }^{4}$ Puesta. (de latim vulg. posta, y este del lat. posita, part. pas. de ponere, poner). 1. Acción y efecto de poner o ponerse. Puesta en escena. 1. f. Montaje y realización escénica de un texto teatral o de un guion cinematográfico. Diccionario de La Lengua Española - Real Academia Espanñola. Vigésima segunda edición, 2001.
} 
de suas obras cinematográficas. Partindo do seu pensamento sobre uma dupla-pertença dos sons, nos aproximamos da obra do pesquisador canadense Murray Schafer em "Breve contexto histórico sobre a paisagem sonora: a experiência acusmática como condição de escuta esquizofônica do mundo".

A partir de uma experiência de escuta acusmática, a incorporação dos sons transformados pelas máquinas e mediados pelos dispositivos sonoros é apresentada pelo autor como sintoma de uma paisagem esquizofônica do mundo. Lugar onde se perde a conexão com os sons em detrimento de uma presença ruidosa, sem perspectiva e sem profundidade. $\mathrm{Na}$ abordagem proposta por Murray Schafer, migramos de uma discussão que nos apresentava uma dimensão estética do som para nos aproximarmos da expressão do som a partir do seu poder cultural, social e político.

Segundo Murray Schafer (2001), a produção de ruídos incessantes no mundo teria paralisado as conexões significantes da audição do sujeito. Esta breve reflexão sobre o contexto da paisagem sonora como escuta esquizofônica do mundo abre questões em relação à subjetividade que o som imprime na percepção humana nos aproximando das obras fílmicas de Lucrecia Martel. Em O Pântano (2001), A Menina Santa (2004) e A Mulher Sem Cabeça (2008), a cineasta se utiliza do som para demonstrar como através da sua percepção pode-se transportar os espectadores para mergulharem na subjetividade dos personagens. Assim, a cineasta usa a experiência de escuta dos sons acusmáticos como uma relação natural do sujeito com o mundo contemporâneo para criar uma representação sonora única nos seus filmes.

Continuando as explorações sobre os ruídos e as suas manifestações como fenômenos sonoros, atravessamos os pensamentos de Murray Schafer para nos aproximarmos dos processos composicionais e estéticos do compositor Pierre Schaeffer. Em "A experiência acusmática como subjetivação do som”, os sons acusmáticos são abordados através da sua 
relação com a escuta reduzida e com os processos de repetição e variação dos ruídos na música concreta. A escuta reduzida foi definida pelo músico concreto Pierre Schaeffer como uma condição de escuta que retira as conotações causais, semânticas e figurativas do som para revelar suas qualidades sonoras específicas. A experiência de escuta de um som acusmático, que se ouve sem reconhecer a imagem da sua fonte causal, foi considerada pelo músico como uma situação que poderia encorajar por si mesma uma escuta reduzida, modificando a percepção dos sons. Pierre Schaeffer acreditava que o processo de repetição de um mesmo fragmento de som, gradualmente, permitia ao ouvinte parar com a indagação de suas causas e promover o "esquecimento da sua significação". Paradoxalmente, podemos constatar que o som acusmático pode promover a atenção do ouvinte para as características sonoras em função da localização das texturas, massas e velocidades do som, mas também possuem o poder de aproximar os ouvintes das causas do som, aumentando sua expectativa em relação aos valores de imagem da fonte sonora.

É no seio desta contradição da poética concreta que destacamos, no segundo capítulo, uma reflexão sobre as práticas de concretização do pensamento sonoro da cineasta que afirmou, em diversas entrevistas (CAHIERS, 2004; SONIDOANDA, 2008), ser guiada durante os momentos de criação e definição dos elementos da sua mise-en-scène por certo tipo de pré-escuta, uma tonalidade pressentida acerca dos seus filmes. A partir de uma entrevista de Lucrecia Martel conferida ao crítico de cinema francês Jean-Michel Frodon (CAHIERS, 2004), pretende-se apontar quais as práticas realizadas pela cineasta e a sua equipe de som para concretização do seu pensamento sonoro, além de promover uma reflexão sobre o uso dos sons e a sua representação nos filmes.

Nas películas de Lucrecia Martel pode-se constatar a incorporação do som em referência aos seus meios eletroacústicos de transmissão (os dispositivos sonoros como rádios, tv's, telefones, celulares e microfones constantemente aparecem nas cenas) e que, num 
contexto particular, estão presentes nos processos de pré-produção, de filmagem e de pósprodução através da representação de uma escuta contemporânea. Nestas três etapas da concretização de um pensamento sonoro no cinema, o ouvido aparece como o instrumento de escuta atrelado a produção sonora dos filmes. Assim, destacamos algumas práticas e maneiras de concretização do pensamento sonoro da cineasta como as suas reuniões com o diretor de som Guido Berenblum, ainda na etapa de pré-filmagem, a fim de definir as qualidades expressivas dos sons de objetos do universo de representação das suas narrativas ficcionais. Na primeira etapa do processo de produção sonora destes filmes, o som é discutido a partir da ideia do afastamento das suas causas e efeitos para promover uma escuta mais consciente das texturas, das massas e da intensidade do som. A definição das qualidades sonoras dos objetos que produziram sons nas cenas d'O Pântano foi determinante para a cineasta estabelecer uma unidade plástica sonora ligada à lógica interna dos filmes e concretizar uma maneira de aproximação do seu universo ficcional. Contudo, ainda movimentando-se dentro de uma ambiguidade sonora, o “esquecimento da significação" (MENEZES, 2009) dos ruídos retorna no final do segundo capítulo como um motivo recorrente na representação das experiências auditivas dos personagens. Em A Mulher Sem Cabeça, os sons de um acidente são subjetivados pela protagonista para permanecerem na sua escuta como a lembrança de uma dúvida mortal. A personagem, molestada por este ruído incômodo, prefere "esquecer a significação" (idem, ibidem, 2009) deste som na tentativa de combater uma "tensão na memória" (BARTHES, 2007).

Como outra possibilidade de estudos de cinema, na segunda parte desta dissertação vislumbramos as experiências cotidianas mostradas nos filmes de Lucrecia Martel. Uma opção de encenação que se distancia dos grandes fatos históricos para promover a aproximação de uma história que está presente no corpo, nos gestos e em pequenos acontecimentos. Nestes três filmes, a busca por uma "encenação do comum" (LOPES, 2012) 
aparece marcada por uma temporalidade do cotidiano. Narrativas onde a espera se apresenta através dos personagens imersos no seu dia-a-dia. Nos três filmes da cineasta Lucrecia Martel, todos os personagens habitam uma pequena e mesma localidade, lugar isolado no norte da Argentina, Salta. As situações cotidianas deste lugar são representadas nos filmes e nós, espectadores, temos a sensação de ter vivido ou ouvido algo parecido em algum outro lugar. Familiarmente estranho ou estranhamente familiar, meu caminho, inicialmente, foi rastrear por onde este estranhamento se manifestava no corpo dos personagens. Fascinados por orelhas, priorizamos na primeira parte da dissertação uma análise dos filmes que parte da experiência de escuta dos personagens; momentos nas quais, por diversas vezes, os personagens foram mostrados experimentando situações auditivas incômodas.

Contudo, pretendemos nesta segunda parte promover uma discussão sobre como os ruídos podem flutuar entre estas duas dimensões, concreta e subjetiva, para revelar momentos de contingência nos filmes. Pequenos momentos de "aparente plenitude do cotidiano" que brotam nos nossos objetos de análise serão mencionados no início desta segunda parte através dos estudos sobre a contingência no cinema realizados por Mary Ann Doane (2002; 2012). A autora nos lembra que a possibilidade da abolição do fugaz e de uma degradação do sentido na linguagem cinematográfica pode acontecer sob a forma de singelos acontecimentos que prendem a atenção ao promover uma evacuação de sentido.

Assim, apresentamos a necessidade de nos voltarmos para uma discussão sobre os espaços e as narrativas no Nuevo Cine Argentino, a partir de uma pluralidade temática e estética que recusou, de certa maneira, uma demanda política e identitária de um movimento. Em virtude de uma conexão com o presente, as produções das últimas duas décadas na Argentina se detiveram em narrações abertas que transformaram as relações entre produção e estética, segmentando a elaboração dos filmes para o seu financiamento por instituições e fundos estrangeiros (AGUILAR apud ROSARIO-NUNEZ, 2009, p.29). Neste sentido, em 
relação ao Nuevo Cine Argentino e a experiência apresentada nos filmes de Lucrecia Martel, distanciamo-nos de classificações estéticas para aceder a transformações de diferentes zonas de produção audiovisual da qual a estética é parte integrante. Nestas duas últimas décadas da cinematografia argentina, outro novo dado também foi incorporado nas produções com a presença de atitudes corporais femininas que aparecem nos filmes como "signos de uma desordem interior, reveladoras de uma subjetividade em crise" (AMADO apud AGUILAR, 2009, p.32).

Em O Pântano, A Menina Santa e A Mulher Sem Cabeça, a presença de uma corporalidade feminina delineia os traços de uma familiaridade confusa. As atitudes corporais dos personagens se manifestam nos espaços da intimidade doméstica; aparecem como ruídos de um mundo onde a relação entre os personagens femininos e masculinos já não é a mesma de anos atrás. Mais de uma vez, a cineasta propõe uma reflexão que gira em torno de atitudes corporais femininas a partir de um terreno movediço, onde as múltiplas possibilidades de representação estão centradas na conversação de vozes: vozes que gritam aos nossos ouvidos e outras que habitam lugares mais profundos, íntimos através de sussurros, rumores de falas do passado e respirações ofegantes.

Prosseguindo, destacamos alguns exemplos sobre como os sons podem ser usados para construção de "uma massa sonora indiscernível”, com ruminações, sussurros e sons audíveis e invisíveis. A partir de uma análise de Gonzalo Aguilar sobre o uso da banda sonora no Nuevo Cine Argentino destacam-se sons e vozes que ocultos (desprovidos de sua imagem) adquirem sentidos que ultrapassam seu sentido semântico: sons promovidos para instaurar uma perturbação nas narrativas (AGUILAR, 2010). Um espaço indiscernível e rarefeito é também mencionado a partir das críticas de David Oubiña (1997) sobre os filmes de Lucrecia Martel. Atenta às diversas possibilidades de se representar o tempo e o espaço no cinema, as obras da cineasta são analisadas pelo crítico por revelarem uma subversão através da acumulação de 
pequenas coisas. O acúmulo de histórias que não se resolvem criam desarranjos espaçostemporais, revelando ações interrompidas. Uma fissura no tempo é criada a partir da sucessão de cortes que sugerem desfechos que nunca serão revelados na imagem, apenas pressentidos através de um resto de som que sobra. Perdido o sentido, um escrínio sonoro será revelado em outro acontecimento na narrativa, provocando uma fissura entre a sensação de tempo passado e tempo futuro.

Assim, na segunda parte desta dissertação, destacamos uma análise sobre a indiscernibilidade do espaço e algumas figurações do tempo e do corpo apresentadas sob a ótica de Ana Amado (2009), David Oubiña (1997) e Gonzalo Aguillar (1997). A partir da interiorização da escuta de Amália (A Menina Santa) e Verô (A Mulher Sem Cabeça), ou com acontecimentos acidentais, externos, concretos e, por isso, irreversíveis mostrados no começo das narrativas de $O$ Pântano e A Mulher Sem Cabeça, foram decisivos para adentramos nos espaços subjetivos e tempos rarefeitos da poética dos sentidos de Lucrecia Martel. 
I -

AS DIMENSÕES CONCRETAS E SUBJETIVAS DO SOM 


\section{Capítulo 1. A Experiência Acusmática}

\subsection{Uma Apresentação de Lucrecia Martel}

Lucrecia Martel nasceu em 14 de dezembro de 1966, na província de Salta, Argentina. Diretora, roteirista e produtora de cinema, a cineasta estudou animação na Escuela Nacional de Experimentación y Realización Cinematográfica (ENERC) em Buenos Aires por alguns anos, além de Ciências da Comunicação. Lucrecia Martel se interessou pelos ritmos e sentidos narrativos do som desde a infância, quando ouvia os contos narrados pela avó durante a hora da siesta. Segundo a cineasta ${ }^{5}$, já naquela época percebia uma dupla qualidade

$5 \quad$ Em “Charla con Lucrecia Martel y el director de sonido Guido Berenblum”, página 2. Entrevista gravada em 12 de novembro de 2008, e acessado em 22/09/2012, no site http://www.sonidoanda.com.ar/descargas.htm vinculado ao departamento de Diseño de Imagen y Sonido de la Universidad de Buenos Aires - CÁTEDRA SEBA/UBA. 
sonora no uso das palavras com os diversos sentidos, significados e também os ritmos, tons, texturas e intensidades presentes nas conversações e contos. Usado como estratégia de imobilização das crianças no meio da tarde, os contos de terror provocavam momentos de fascinação na cineasta através de uma puesta en sonora ${ }^{6}$ praticada pela sua avó. Nas suas primeiras experiências cinematográficas, esse modo de percepção em relação aos relatos e narrativas se transformou de distintas maneiras até se concretizar numa forma de observar as coisas do mundo, uma percepção de algo em relação às cenas que precedia o pensamento sobre a trama. Em 1983, Martel ganhou a primeira câmera de vídeo do seu pai. Câmera fixa, pessoas transitando pelos espaços da intimidade - a cozinha, o corredor que liga a sala com os quartos, o banheiro. Cinco horas de movimentação! Filmando muito tempo do cotidiano da sua família, a cineasta foi criando um arquivo memorial com o registro dos momentos de intimidade da sua casa.

Florescia, antes de tudo, um modo de criação e de aproximação do universo da representação fílmica dado pela experiência da observação de imagens e sons do cotidiano da cineasta. O universo de conversações familiar que proporcionou durante sua infância uma percepção de ambientes sonoros e situações de ritmo, alterando a compreensão do sentido das palavras, fez com que a cineasta estabelecesse uma premissa sonora diante da criação de suas obras - a de que "o som exerce uma dupla qualidade, quando emitido através de palavras

\footnotetext{
6 "Yo siento que la deuda mas grande que tengo yo en el trabajo de cine es con las narraciones orales familiares: los cuentos... muchas cosa que en mi casa esta relacionada con las mujeres, con el mundo de las mujeres, las fotos de mi abuela, las conversaciones, las visitas a casa de amigas de mi abuela, el mundo de las conversaciones es creo yo el espacio sonoro que primero me cautivo. [...] Cuando yo era chica, la hora de la siesta, era una hora donde nos trataban de dejar quietos en un cuarto para que puedan descansar las personas, es un horario bastante sagrado en el interior, en las provincias, y si los chicos están gritando en la calle o en la casa, es un horario imposible para los adultos que trabajan, y en esse horario mi abuela con los cuentos de terror, la mayoría terribles y espantosos, trataban de inmovilizarmos y efectivisimamente a tal punto que es el día de hoy que todos mis hermanos y yo para subir a la cama saltamos como si fuera una isla a la que hay que llegar evitando las zonas adyacentes porque puede salir algo de abajo de la cama y agarrarte. El sonido mas allá del sentido horroroso de los cuentos, el sonido y el ritmo de esos cuentos, tenia como objetivo inmovilizar, atrapar, dejar quieto a criaturas, y me parece a mi y por supuesto que esto no es algo de lo que me daba cuenta a los seis o siete años, pero con el tiempo la fascinación que gerebaban esas horas, no eran solamente el contenido de los cuentos, sino que era toda esa puesta em escena sonora de mi abuela para inmovilizar, asíque creo yo que la primera relación que tengo con lo narrativo y el mundo del relato es sonora". (idem, ibidem, p. 2)
} 
pode conter muitíssimos sentidos além do que significam os seus ritmos e seus tons ${ }^{7}$ ". Nos seus filmes, os sons deveriam ser usados em relação à importância dada ao sentido das palavras e aos outros sentidos conferidos pelas qualidades sonoras. Distante de uma formação a partir das regras de manuais de roteiro, a cineasta preferiu voltar-se para o seu universo familiar e cotidiano em busca de uma atitude perceptiva específica que pudesse concretizar suas ideias sonoras nos filmes. No caminho da formação de sua puesta en escena sonora, Lucrecia Martel dirigiu alguns curtas entre 1988 e 1995, dentre eles, El 56 (1988), Piso 24 (1989), Besos Rojos (1991) e Rey Muerto (1995), este último integrou a coletânea de curtasmetragens argentinos "Historias Breves" e foi vencedor do prêmio Coral do Festival de Cinema de Havana, na categoria "melhor curta-metragem". Para a televisão também criou obras como D.N.I. (1995), Magazine For Fai (1996) e o documentário Las Dependencias (1999). Nestes filmes, os temas retratados pela cineasta são diversos e vão desde um faroeste ficcional baseado numa experiência pessoal $\left(\right.$ Rey Muerto $\left.^{8}\right)$ até a biografia da escritora Silvina Ocampo (Las Dependencias) ou simplesmente um estado sensorial destacado por beijos provocantes (Besos Rojos). Para a cineasta, suas observações de experiências cotidianas, relatadas sempre sob um tom não realista, aparecem assim talvez porque chegam atravessadas pela ótica do que permaneceu daquele seu arquivo memorial; como uma áudio-visão das reminiscências do seu passado.

Em 2001, seu primeiro longa-metragem apresentou uma família da classe média salteña vista de um lugar um pouco estranho. Em O Pântano (La Ciénaga), vencedor do Urso

\footnotetext{
7 "el sonido tiene la doble cualidad de cuando son palabras tener muchísimos sentidos y además todo lo que significa los ritmos, los tonos" (MARTEL, 2008). A entrevista da cineasta Lucrecia Martel e do diretor de som Guido Berenblum foi concedida à Alejandro Seba, por ocasião de uma palestra conferida para Cátedra Seba, na FADU/Universidad de Buenos Aires, em 12 de novembro de 2008. "Charla com Lucrecia Martel y Guido Berenblum", disponível e consultado em 08/08/2012, no site http://www.sonidoanda.com.ar/

${ }^{8}$ A cineasta relata em entrevista a revista El Amante (2001, n.100 - Es de Salta y hace falta!) que na sua infância observou uma briga entre o verdureiro e a sua mulher, na cidade de Salta. A mulher enfurecida atacava o marido com uma faca enorme e o homem se protegia com uma caixa de madeira. O curta-metragem Rey Muerto, que posteriormente foi incluído na coletânea de curtas argentino Histórias Breves, nasceu desta pequena história. O filme de 12 minutos tem como trama principal a história de uma mulher que junto aos seus filhos foge da cidade depois de uma brusca separação do marido.
} 
de Ouro de Berlim e de vários outros prêmios, não vemos as transições espaciais, nem uma paisagem ampla e bonita, não se escutam músicas extra-diegéticas na trilha sonora - suas músicas surgem de dispositivos sonoros em cena - e os personagens são apresentados a partir do acontecimento de acidentes. Com um modo de visão e de escuta muito particular, esta diretora foi apurando sua sensibilidade em relação ao mundo e definindo uma maneira de filmar seus objetos e temas de interesse. Estratégias estabelecidas nem tanto por sua formação intelectual, mas principalmente por um modo de percepção do sensorium que ressalta as potencialidades narrativas e expressivas do som no cinema. Posteriormente, em 2004, escreveu e dirigiu o longa-metragem A Menina Santa (La Niña Santa), com o qual concorreu à Palma de Ouro do Festival de Cinema de Cannes e recebeu menção honrosa dos críticos no Festival Internacional de Cinema de São Paulo, no mesmo ano. Nestes dois primeiros longasmetragens, a cineasta incorpora a sonoridade de objetos diegéticos como elementos de expressão e como meio de sugestão e simbolização.

Fugindo de um condicionamento do espaço e tempo lineares, a dissociação entre som e imagem dada nos seus filmes com o uso do espaço fora-de-campo ressalta as tensões, a não coincidência, as lacunas e as rupturas fomentando uma discussão sobre o cinema como lugar da efetuação de fenômenos sensoriais. Com a observação de situações emocionais da intimidade familiar, o espectador tem que lidar com uma perturbação criada sobre aquilo que nem sempre tem uma explicação causal e não é visto na tela. Retirada a possibilidade da demarcação de um espaço e de um tempo linear e estável, o espectador encontra-se submergido numa permanência de sensações e estados afetivos dos personagens representados através de suas experiências auditivas. Impedidos de enxergar as fontes dos sons que surgem nas cenas, os personagens são molestados por sinais acústicos de Deus ou por ruídos inaudíveis causados pela Síndrome de Manière.

Assim como A Menina Santa, seu terceiro longa-metragem A Mulher Sem Cabeça ( $L a$ 
Mujer Sin Cabeza, 2008) foi coproduzido pelos irmãos Almodóvar e indicado à Palma de Ouro no Festival de Cannes. Neste filme, um aparente estado de afasia e apatia demarca uma instabilidade na narrativa posterior a audição de um som forte dado no espaço fora-de-campo. A personagem Verônica (Maria Onetto) mantém-se perturbada e duvidosa em relação a causa desse estrondo - neste caso, o som de um atropelamento que pode ter sido produzido pelo impacto de um cachorro ou de uma criança no carro. A trama deste filme é conduzida, desde seu início, pelo elemento fantasmático desta presença-ausência: o rastro estrondosamente sonoro que remete ao atropelamento. Uma atmosfera de suspensão espaço-temporal se instala no filme através de elementos que não foram vistos, mas ouvidos e partilhados entre a protagonista e os espectadores.

Imagem que nunca se vê, a morte se precipita nas suas narrativas ficcionais através do uso do som fora-de-campo, evidenciando assim, um lugar potencialmente virtual, podendo ser simplesmente a continuação do que o campo delimita ou ainda podendo enfraquecê-lo. Nestes filmes, a perda da referencialidade das fontes sonoras, a permanência das sensações e estados afetivos aparecem como demarcação de uma instabilidade; uma presença-ausência que habita o espaço da representação (a dúvida da morte).

Com efeito, através do uso do som, da representação de um modo de escuta e da sua articulação específica com a imagem - a experiência de escuta acusmática (SCHAEFFER, 1988)-, são relativizadas as articulações entre o campo e o fora-de-campo - como elementos constitutivos do imaginário e da ficcionalização - e entre o quadro e o fora-de-quadro como elementos para a construção da diegese, o espaço da representação (AUMONT, 2012).

$$
* * * * * * *
$$

Recentemente, a cineasta produziu e dirigiu os curtas-metragens Nueva Argirópolis (2010), Pescados (2010) e Muta (2011). 


\subsection{Breve contexto histórico sobre a paisagem sonora: a experiência acusmática como condição de escuta esquizofônica do mundo}

Desde o século XIX, são intensas as transformações ocorridas no ambiente acústico mundial. A industrialização e a urbanização nas grandes cidades modificaram significativamente os sons do nosso cotidiano. Sirenes, buzinas, motores e, recentemente, os sons digitalizados intensificaram a proximidade existente entre os homens e as máquinas. As formas de geração, difusão e amplificação dos sons mudaram, radicalmente, com as invenções de novos dispositivos sonoros como o telégrafo, o telefone e o fonógrafo. No livro $A$ Condição da Escuta: mídias e territórios sonoros (2008), o músico Giuliano Obici aproxima os conceitos de acusmática, proposto por Pierre Schaeffer (1988) e esquizofonia, de Murray Schafer (2001) com o intuito de demonstrar como esses dispositivos sonoros inauguraram novas formas de escuta através da "presentificação" de fontes sonoras invisíveis (OBICI, 2008, p.22). A partir de uma investigação sobre os novos dispositivos sonoros e modos de escuta reproduzidos ao longo do século XX, Obici (2008) nos apresenta uma reflexão sobre como o excesso e a fragmentação dos ruídos das máquinas afetou a experiência auditiva do ser humano.

Conforme Obici (2008), para o músico e pesquisador Murray Schafer (2001), no início do século passado três novos dispositivos sonoros provocaram uma revolução nos modos de percepção e no comportamento humano e "com o telefone e o rádio, o som já não estava mais ligado ao seu ponto de origem no espaço" (SCHAFER, 2001, p.132). Por sua vez, "com o fonógrafo ele [o som] foi liberado de seu ponto original no tempo" (idem, ibidem p.132). Obici (2008) destaca ainda, que novas técnicas reproduzidas nas mídias sonoras como a 
introdução da dinâmica, dos efeitos de eco, da separação de recursos, a incorporação de dispositivos com qualidades referenciais específicas e o uso do gravador para fazer incisões em um material gravado significaram uma quebra no tempo entre o passado e o futuro. Para o autor, com a incorporação dessas novas técnicas o homem se via diante de um novo poder através da possibilidade de viver num mundo fragmentado, repleto de espaços acústicos "interrompidos" (OBICI, 2008, p. 22).

Na perspectiva do pensamento sonoro de Murray Schafer, "o rompimento entre um som original e a sua transmissão eletroacústica estaria diretamente relacionado ao uso da palavra esquizofrenia; conferindo, assim, um sentido de aberração e drama para o afastamento dos sons do seu contexto original" (SCHAFER, 2001, p.135). O conceito de "esquizofonia" é usado na pesquisa de Murray Schafer para se referir aos efeitos causados no comportamento dos seres humanos ao lidarem com uma paisagem sonora esquizofônica, cujo ambiente acústico $l o-f i^{9}$ está marcado profundamente pela presença de sonoridades constantes e pouco definidas. Com uma grande densidade de sons ruidosos, o sinal de ruído é mascarado e “perde-se a perspectiva. Na esquina de uma rua, no centro de uma cidade moderna, não há distância, há somente presença" (idem, ibidem, p.72). A "presentificação" de sons invisíveis no mundo urbano e industrializado estaria caracterizada pelo poder dos ruídos das máquinas, sendo percebidos como um fundo sonoro indiscernível.

$\mathrm{Na}$ contemporaneidade, o excesso de produção de ruídos nos proporcionaria uma experiência auditiva no mundo marcado por uma condição de "escuta anestesiada" (OBICI, 2008, p.48), "próximo à agonia de sentir o ego desfragmentado" (idem, ibidem, p.47). Conforme Obici:

\footnotetext{
${ }^{9}$ SCHAFER, Murray. “Abreviação de baixa fidelidade (low fidelity), que é uma razão sinal/ruído desfavorável. Aplicado aos estudos da paisagem sonora, o ambiente lo-fi é aquele em que os sinais se amontoam, tendo como resultado o mascaramento ou a falta de clareza". Em A Afinação do Mundo, 2001, p.365.
} 
M. Schafer diagnostica na paisagem sonora a atrofia do sensível como um estado de falência. Assim como o esquizofrênico artificial dos hospícios é aquele que esgotou, ou ainda, que levou ao máximo a potência de produzir conexões, atingindo um estado de paralisia, a esquizofonia descrita por M. Schafer tende à paralisia dos ouvidos (OBICI, 2008, p.48).

A partir do conceito de esquizofonia, Murray Schafer (2001) apresenta a experiência auditiva contemporânea como sintoma de um modo de produção capitalista esgotado, onde o ser humano encontra-se paralisado diante da produção incessante de conexões de sentidos e informações. Como antídoto para combater esse "estado de paralisia auditiva", Schafer propõe uma "limpeza dos ouvidos", onde a primeira tarefa dos ouvintes seria reaprender a ouvir nos espaços acústicos (SCHAFER, 2001, p. 291). Schafer (2001) refere-se ao espaço acústico como um volume de espaço no qual o som pode ser ouvido, definindo por suas linhas acústicas uma comunidade ideal (idem, ibidem, p.299). Espaço acústico onde os sons dos detalhes do cotidiano ainda podem ser percebidos sensivelmente. Nesta comunidade acústica lugar onde o homem deve habitar uma área da qual se pode ouvir a sua voz - a experiência de escuta é dada pelo silêncio. Na experiência proposta por Murray Schafer, os ouvintes "projetistas acústicos" $" 10$ (idem, ibidem, p. 288) devem aprender a respeitar os momentos de silêncio para preservação das marcas sonoras, do ritmo e do tempo do espaço acústico. Os sons, mesmo ouvidos em volume mínimo, devem ser percebidos audíveis e significantes, mantendo a referencialidade das coisas em relação ao mundo.

Obici (2008) aponta uma contraposição entre as diferentes abordagens do músico

\footnotetext{
10 Com este termo, o autor estabelece uma relação entre arquitetura e engenharia acústica a partir da figura do projetista acústico, um tipo de ouvinte especializado em paisagem sonora que desenvolve a tarefa de planejar os efeitos destinados a provocar respostas específicas nos ouvintes. O projeto acústico do compositor tenta resgatar a importância do amplo tema da reconstrução ambiental em espaços públicos, demonstrando uma estreita relação entre o espaço arquitetural e os seres humanos. Segundo Schafer (2001), o projetista acústico ou o compositor, antes de tudo, devem conhecer o seu material, o ambiente com o qual está lidando a partir de uma compreensão de distintas áreas como a acústica, psicologia, sociologia, música, fisiologia, biologia, artes; “trata-se na verdade de promover o resgate de uma cultura auditiva significativa, o que é uma tarefa de todos” (2001, p.288).
} 
concreto Pierre Schaeffer e do pesquisador e músico canadense Murray Schafer, acerca da influência dos novos dispositivos sonoros e modos de escuta no comportamento humano. Impondo certa distância da abordagem negativa ${ }^{11}$ dos ruídos afirmada pela ecologia acústica de Murray Schafer, propõe-se uma aproximação da experiência da percepção auditiva na música concreta. Com a aproximação do conceito de experiência acusmática proposto por Pierre Schaeffer, pretende-se refletir sobre a possibilidade de uma experiência auditiva cinematográfica que emprega práticas de descondicionamento dos sons de suas conotações simbólicas tradicionais. Pierre Schaeffer (1988) nos apresenta uma abordagem da escuta acusmática como um instrumento capaz de tornar audíveis e nos afetar sensivelmente através da revelação de forças sonoras inaudíveis e invisíveis.

\section{3. A experiência acusmática como subjetivação do som}

Na música concreta, o termo acusmático se fixa aderindo ao aspecto da escuta presente em nosso cotidiano a partir do surgimento de dispositivos sonoros com alto-falantes. Em "Tratado de los objetos musicales"12 Pierre Schaeffer refere-se ao rompimento entre um som

\footnotetext{
${ }^{11}$ Ver OBICI, Giulianno. "A Condição da Escuta: mídias e territórios sonoros”, 2008. Conforme Obici, “A esquizofrenia é o universo das máquinas desejantes produtoras e reprodutoras, a universal produção primária como 'realidade essencial do homem e da natureza". (Deleuze, Guattari apud OBICI, 2008). Segundo o autor, no livro AntiÉdipo: esquizofrenia e capitalismo, de 1972, Deleuze aponta que a máquina não se restringe somente ao aparato físico, mas a todo tipo de situação que gera algum funcionamento de algo humano ou não-humano. Neste livro, a esquizofrenia é trabalhada como um modo de produção, e o esquizofrênico um produtor universal. "O esquizo seria uma fonte desejante de fluxo contínuo, que está em constante atividade, operando sempre por cortes e ligações numa produção incessante de sentidos. Essa concepção do termo subverte as visões psicanalíticas e psiquiátricas da doença e a lógica do capital." Obici propõe a concepção deleuziana do termo como contraposição ao pensamento schaferiano de "aberração" e "drama". A partir dessa mudança no sentido, a esquizofonia, como funcionamento da escuta a partir de situações geradas pela produção constante de sons, disponibiliza um estado de ligação e corte constantes nos fluxos sônicos. Produz ininterruptamente escutas e relações com o mundo que não necessariamente tem um sentido negativo, como na obra de Murray Schafer.

${ }^{12}$ Ver SCHAEFFER, Pierre. "Acusmatico, se dice de un ruído que se oye sin ver las causas de donde proviene". Tratado de los objetos musicales. Madrid: Alianza Editorial, 1988. Versão espanhola da obra completa "Traité
} 
original e a sua cadeia de transmissão eletroacústica como "acusmático, é um ruído que se ouve sem ver a sua fonte sonora causal" (SCHAEFFER, 1988, p.57). O autor nos propõe uma abordagem do termo na esfera da linguagem musical, relacionando o som acusmático para promover uma escuta reduzida através da cisão entre o som e a imagem. A situação acusmática contribui para a experiência de um novo modo de percepção para apreensão do “objeto sonoro em si”. Experiência marcada pela "destituição da relação causal da escuta, retirando [o som] de um contexto que se impõe pelo olhar, pela posição dos corpos, seus movimentos e gestos" (OBICI, 2008, p.31-32).

No pensamento sonoro schaefferiano, com os adventos tecnológicos sonoros transformaram-se as relações de fazer e de escutar os sons. Na década de 50, a partir das técnicas de captação e registro para isolamento do acontecimento sonoro faz-se da escuta um instrumento de análise e experimentação do som. Schaeffer nos apresenta o ouvido como um instrumento de análise para promover uma discussão em torno da dimensão subjetiva e objetiva da escuta que, em sua obra nunca será dissociada da produção. Conforme Obici (2008), a experimentação sonora na música concreta de Pierre Schaeffer "propunha o contato direto com o objeto sonoro, no qual o aprendizado da própria sonoridade [do mundo] se impunha a qualquer estruturação musical” (OBICI, 2008, p.12). Assim, a concepção de música afirmada pela poética concreta inaugurava "o formato sonoro de uma arte midiática" (GARCIA apud CAMPESATO, 2007, p.12) delimitada pelos efeitos técnicos ${ }^{13}$ do microfone e do alto-falante.

Com o advento da fonofixação, a transformação dos modos de produção e recepção sonora se fixou na formulação da ideia "de uma pan-música, de uma música na qual cada

des Objets Musicaux”, Paris: Editions du Seuil, publicado originalmente em 1966, p. 57.

${ }^{13}$ No âmbito da música eletroacústica, a obra que passa por um processo de fonofixação oferece uma maneira particular de escritura e de decodificação. Conforme o musicólogo Michel Chion (1994), optamos pela adoção da classificação dos efeitos técnicos de base em seis níveis: captação, telefonia (retransmissão), fonofixação (gravação), amplificação, geração e remodelagem (manipulação). (CHION, 1994, p. 13-23) 
evento sonoro possa ter seu lugar - na medida em que a intenção assim o deseje" (MENEZES, 2009, p.18). A incorporação do ruído a partir das suas qualidades sonoras e a separação entre o som e a imagem da sua fonte sonora possibilitava para o músico concreto a perda da referencialidade na linguagem musical. A obra fonofixada criou um novo modelo de performance musical, "composta por aquilo que foi fonocaptado, fonofixado, amplificado, transmitido por telefonia" (VALENTE, 2012, p.4), e posteriormente, por sinal digital.

No final dos anos 40, após as contribuições de compositores modernos como Stravinsky e Edgar Varèse que inseriram sons ruidosos em suas peças musicais clássicas, uma das primeiras experiências musicais de Pierre Schaeffer foi veiculada em outubro de 1948 com a difusão do Concert de Bruits pela RTF - Radiodiffusion-Télévision Française. O Concert de Bruits foi apresentado pelo músico e radialista como uma série de pequenos estudos musicais. O material apresentado era, prioritariamente, produzido com os sons de passos, de portas, das vozes e de máquinas que foram captados, fixados no suporte da fita magnética e remontados no Studio D'Essai, desde 1942. Em 1952, Pierre Schaeffer publicou “À La Recherche de Une Musique Concrète: Esquisse d'une solfège concret" no qual formalizou algumas das suas primeiras ideias sobre a música concreta, termo cunhado pelo autor desde 1948. A composição da música concreta era produzida diretamente no suporte material, não passava por notações gramaticais e não se importava sobre a origem do som - se instrumental, sintético, objetual ou ambiental. Neste período, a discussão realizada pela proposta da música concreta enfatizava uma nova experiência contemporânea em suas diversas modalidades de criação e de escuta. Como principais mudanças apresentadas, destacamos a importância dada à compreensão das potencialidades da percepção sonora e sobre o descondicionamento de conotações culturais relacionadas à escuta. Com o grande avanço das mudanças técnicas e tecnológicas, as formas de contemplação naturais da música foram transformadas e desritualizadas quando saídas das salas de concerto para tocarem repetidas vezes nos 
dispositivos sonoros domésticos.

Neste contexto, Menezes (2009) aponta que a repetição na poética concreta era empregada para que se pudesse “esquecer a significação" (MENEZES, 2009, p.18), questionando assim "o dado mais fundamental do percurso histórico da música ocidental: o fato de que a evolução das formas constitua em si mesma o próprio objeto da música escrita" (idem, ibidem, p. 19). Neste processo composicional, a dissociação entre significação e forma era realizada por meio da variação da matéria, destituída da sua significação pela separação do som do seu ataque característico. O processo composicional típico da música concreta, ao incorporar ruídos extraídos do cotidiano, afirmava-se radicalmente em oposição à "abstração" da escrita musical, promovendo a desnaturalização da fonte sonora.

Separar o som do ataque constituía o ato gerador. Toda a música concreta estava contida em germe nesta ação propriamente criadora da matéria sonora. [...] A música clássica abstrai, parece-nos, formas de toda matéria. A música concreta, ao contrário, dá as costas a tais formas puras, e, se ela renova a matéria, apresenta-se também como uma espécie de enorme degradação. (SCHAEFFER apud MENEZES, 2009, p. 19)

Como aponta o compositor Flo Menezes, a proposta de música eletroacústica de Pierre Schaeffer caracteriza-se contraditória na linguagem musical a partir dessa concepção da dialética apresentada entre matéria e forma. Menezes (2009), no livro "Música Eletroacústica: histórias e estéticas", discorre que a compreensão da poética concreta schaefferiana emergiu destes dois aspectos paradoxais: por um lado, a associação direta da significação à forma; de outro, o fenômeno musical poderá emergir, apenas por meio de uma variação da matéria destituída de significação (MENEZES, 2009, p.19).

Em “A experiência da música e as escutas contemporâneas”, o pesquisador Rodrigo Fonseca e Rodrigues ressalta que a música concreta surgiu a partir de um contexto no qual a inflação de signos sonoros e a exposição excessiva foram decisivas para repensar na música o 
que "contribuiu para dissolver o culto e a demanda ritualizada de concentração da experiência tradicional” (RODRIGUES, 2002, p. 116). A experiência dada através de sons cotidianos foi enfatizada por diversos músicos que surgiram neste contexto. Como exemplo, Rodrigues destaca as obras de John Cage, que desde suas primeiras composições (como em Imaginary Landscapes, 1939) nos chama atenção para apreciação dos ruídos diários. Trata-se de "descobrir e deixar-se levar pela diversidade material que é gerada pela reiteração de padrões sonoros, não abarcável pela representação" (FERRAZ apud RODRIGUES, 2002, p. 117). Segundo Rodrigues (2002) a música criada por John Cage realiza uma subversão da sintaxe musical para além das propostas de uma escuta schaefferiana que se atenha a sua sonoridade mesma. Na escuta material do som empregado pelo minimalismo, o ouvinte é exposto a jogos reiterativos com durações mais longas que o habitual para redefinir a escuta do ouvinte na intensidade perceptiva de cada momento. Evidentemente, trata-se não apenas do surgimento de novos modelos performáticos na linguagem musical, mas também de um grande debate promovido em torno da inserção do ruído como um elemento contestador do sistema tonal.

A partir dessas novas premissas nos processos de criação da música concreta e do minimalismo propunha-se uma crítica à forma pura e abstrata de uma escritura musical apoiada em elementos notados e redigidos da música clássica. O âmago desta contradição caracteriza-se no fato de o próprio compositor Pierre Schaeffer admitir, em um segundo momento do seu trabalho, o caráter eminentemente linguístico e perigoso dos ruídos. Desse ponto de vista, com a admissão de uma abordagem linguística nas operações que mantém esforço de articulação entre ruídos cria-se um ponto de fissura no processo composicional da música concreta.

$\mathrm{Na}$ linguagem cinematográfica, similarmente, é no esforço empreendido no processo de organização dos sons em relação à imagem e a narrativa que a matéria sonora repetida passa a 
comportar um potencial significante. Mesmo quando excluída do campo de visão do espectador, a matéria sonora ainda relaciona-se com o domínio dos fragmentos sonoros extraídos do cotidiano dos personagens, plenos de um poder associativo, significante e referencial. É neste sentido, no qual se delineia uma contradição evidente e com o qual podemos estabelecer conexões entre as formas de significação na linguagem audiovisual e as experiências de escutas da música concreta e minimalista.

Neste momento, nos aproximamos novamente dos objetos de análise desta dissertação para destacar as possibilidades de experiências de escutas destacadas nos filmes de Lucrecia Martel. Interessada na representação cinematográfica de experiências de estiramento do tempo, da fragmentação do movimento e da contingência, a cineasta aposta numa nova forma de organização entre a imagem e a banda sonora para concretização do seu pensamento sonoro na linguagem audiovisual. No seu processo de criação, podemos apontar que uma dupla-pertença expressiva do som - incorporando as qualidades materiais do som e os seus sentidos diversos (semânticos, causais e figurativos) - ressurge primeiramente na proposta de uma experiência de pré-escuta da cineasta para num segundo momento aparecer na representação da experiência auditiva dos personagens dos seus filmes. Contudo, antes de adentrarmos no universo de representação dos filmes de Lucrecia Martel, faz-se necessário contar um pouco a história sobre como o termo acusmático se insere na linguagem audiovisual. Com os estudos sobre o som no cinema promovido por Michel Chion, um dos discípulos do músico concreto Pierre Schaeffer, o termo se insere na linguagem audiovisual através da possibilidade de criar sobre a imagem diversas temporalidades e da manutenção de um suspense em relação ao segredo da causa e do aspecto físico da fonte sonora emissora do som. 


\subsection{Deslocamentos, posições e trajetórias: a experiência acusmática no cinema}

Chion (2011) adota o termo acusmático de Pierre Schaeffer para contrapor-se a escuta visualizada na linguagem cinematográfica. Conforme o autor (2011), em "sentido estrito, o som fora de campo no cinema é o som acusmático relativamente àquilo que é mostrado no plano, ou seja, cuja fonte é invisível num dado momento, temporária ou definitivamente" (CHION, 2011, p.62). O autor detém-se em apontar dois tipos de trajetórias que os sons estabelecem ao serem organizados no processo de montagem audiovisual: sons que podem ser imediatamente visualizados e depois acusmatizados (saem para o espaço fora-de-campo), e sons que podem ser inicialmente acusmáticos para serem visualizados posteriormente (entram no campo de visão).

Conforme Chion (2011), um som que é inicialmente acusmático, é “próprio dos filmes de mistério e de ambiente, preserva durante muito tempo o segredo da sua causa e do seu aspecto, antes de revelá-la. Mantém um suspense, uma expectativa, e constitui em si um processo dramatúrgico puro, análogo a uma entrada em cena anunciada" (idem, ibidem, p.61). Para Chion, um som ou uma voz mantida acusmática tem a possibilidade de representar diversas temporalidades ou mesmo momentos de suspensão na narrativa. Ainda assim, na linguagem cinematográfica, com a imagem e o contexto narrativo, quase sempre nos relacionamos com o som através da sua causalidade. Segundo Chion (1999), as formas distintas de causalidade foram adotadas pela reprodução sonora na linguagem cinematográfica para manter um acordo com as concessões naturalistas. O "causalismo sonoro" - explicado pelo autor como uma das formas que adota a ideologia do naturalismo (p. 163) - acontece em diferentes meios de reprodução sonora quando: 
hay una reducción implícita del sonido a algo fundamentalmente distinto de él, su causa o sus causas - ya sean reales, supuestas o imaginadas -, o bien el lugar, las circunstancias, el marco de su emisión, etc., y cuando esta redución es una doctrina que se hace pasar por un "hecho natural" que no se puede poner em duda; o también cuando es uma elección estratégica y comercial que permite vender un producto artístico, terapêutico u otro".(CHION, 1999, p.163)

Paradoxalmente, a adoção de concessões naturalistas na linguagem cinematográfica permitiu que se empregassem investigações estéticas sobre a sua matéria, a forma e a textura em função da cena. Porém, o estabelecimento de regras ou de uma doutrina causal teria contribuído para ocultar da audição dos espectadores diferentes sons e diferentes modos de articulação sonora ${ }^{14}$. Um som não necessariamente precisa ser semelhante à imagem e, muito menos a sua especificidade figurativa está atrelada a uma discursividade, ao contrário, é "quando surge a semelhança - ou seja, quando ela aparece por aparição, por inevidência, por inquietude, por abertura e por estranhamento" (DIDI-HUBERMAN, 2011, p.26) ${ }^{15}$ que os ouvidos se abrem aos diferentes sons. Para Chion, é necessário correr o risco de romper essa unidade "natural" entre o som e a imagem cientificista (2011, p.165), ou se pensarmos nos termos do filósofo Didi-Huberman (2011) “entrar num tempo e num lugar do fascínio da ameaça para romper o arranjo do próprio pensamento" (DIDI-HUBERMAN, 2011, p. 50). No combate das consequências de uma posição naturalista, Michel Chion elege os sons acusmáticos - invisíveis pela sua dissociação da imagem da fonte sonora e não ilustrativos à imagem - como elementos expressivos poderosos, capazes de despertar os sentidos

\footnotetext{
${ }^{14}$ Ver Chion, M. 1999, p. 164. "Los efectos negatives de este causalismo en el plano del conocimiento, de la investigación y de la creación son, em cambio, numerosos: el oyente, el investigador y el compositor "dejan escapar" la riqueza y la diversidad de los sonidos que les oculta la unicidad de la causa reconocida. [..] e inversamente, se vuelven sordos em la relación con la identidad de otros sonidos que se encuentran más allá de la disparidad de sus orígenes.[...] Una acción circular no produce un sonido circular; una fuente voluminosa no desencadena forcozamente un sonido voluminoso; un choque violento no tiene necessariamente como consecuencia un ruído intenso, y assi sucessivamente".

${ }^{15}$ Ver Didi-Huberman, Georges. "De semelhança à semelhança: a semelhança interminável como vasta noite", Revista Alea, n. 13, volume 1, 2011.
} 
perceptivos dos espectadores em busca de um fascínio, de uma ameaça, do inacessível e do irreversível.

Em “Audiovisão" (2011), o autor elege ainda um grupo de cineastas do passado que não aceitaram manter as concessões naturalistas, a qual também se refere como uma ilusão de "amálgama" natural entre o som e a imagem. Estes cineastas clamavam em "um grande grito ecológico: dêem-nos um som completo e sem aditivos" (CHION, 2011). Jean-Marie Straub e Danièlle Huillet, Jacques Rivette, Hitchcock, Fritz Lang, Jacques Tati e Marguerite Duras teriam sido cineastas que, de alguma maneira, clamaram pelos efeitos perceptivos de estranheza com o som, subvertendo técnicas e procedimentos para fugir do "trompe-l'oreille" (idem, ibidem, p.80). A imagem, o som, o cenário e todos os outros elementos expressivos dos seus filmes eram estruturados respeitando uma forte lógica interna, em função de uma encenação ou mesmo da sua contestação (CHION, 2011, p.76). Hitchcock (Psicose, Blackmail e Janela Indiscreta), Jacques Tati (As Férias do Sr. Hulot) e Fritz Lang (M.- O Vampiro de Dusseldorf) manipulavam as gravações de som direto, dublavam seus filmes, escumavam os sons. Mesmo assim, são mencionados ao longo do livro pela exploração de procedimentos da linguagem cinematográfica que enfatizaram o uso da dissociação entre o som e imagem (sons fora-de-campo), da profundidade (sentimento de afastamento da fonte sonora) e das variações de extensão do campo (contenção do espaço com os rumores da cidade). Jacques Rivette, em A Religiosa (La religieuse, 1966) e Marguerite Duras, em India Song (1975) deixavam os sons demoradamente no fora-de-campo para depois serem ligados à imagem, onde reencontravam o vazio provocado por um silêncio.

Chion cita cenas de trajetórias orais singulares, lugares percorridos pelas vozes e pelos sons (rumores, ruídos fisiológicos, ruminações) que são tão singulares como os corpos dos personagens que aparecem em tela. Opacos aos sentidos, os sons surgem de lugares ocultos onde os discursos não eram permitidos a esses personagens. Segundo o autor (2011), os mais 
radicais desses cineastas pagaram o preço da perda da inteligibilidade dos elementos sonoros nos seus filmes e provocaram um efeito de estranheza total no espectador (idem, ibidem, p.5759). Em 1970, os cineastas Jean-Marie Straub e Danièlle Huillet escreveram o manifesto "Othon contra a dublagem"16. O manifesto partiu de uma recusa dos cineastas em "sacrificar" seus filmes com um processo de dublagem, que "(sur) prende a vida" (STRAUB-HUILLET, 2012, p. 29) ${ }^{17}$. Em defesa do filme Othon... ou [Os olhos não querem sempre se fechar ou talvez um dia Roma se permita fazer a sua escolha], de 1969, os cineastas afirmavam que trata-se de um filme que se fundamenta nas coisas que não podem ser reproduzíveis. Para os cineastas Straub e Danièle Huillet (2012), o uso da dublagem seria uma substituição terrível, processo enganador da consciência mental do espectador. Citando Pierre Schaeffer e Lênin, Jean Marie Straub afirmava que "a indústria culturalou a cultura de massas são um mito totalitário, ao qual recuso me sacrificar dublando Othon. Não creio na massa, creio nos indivíduos, nas classes sociais e nas minorias (STRAUB-HUILLET, 2012, p. 28). Para o casal de cineastas, a condenação da dublagem e de procedimentos que escumam os sons não se reduzia a uma questão naturalista e sim perceptiva, já que diziam os sons fornecem ondas que são contidas pelos espectadores. No cinema de Straub-Huillet, "as ondas que um som transmite não são apenas ondas materialmente sonoras. [São] as ondas das ideias, dos movimentos, dos sentimentos que também passam pelo som” (STRAUB-HUILLET, 2012,

\footnotetext{
16 STRAUB-HUILLET; Ernesto Gougain (org.)... [etc e tal]. Ver “Othon contra a dublagem"- São Paulo. Catálogo da Mostra Straub-Huillet, Centro Cultural Banco do Brasil. Publicação original: "Il doppiagio é un assassinio. Othon contro il doppaggio". In Filmcritica, número 203, janeiro de 1970. O manifesto lido foi uma versão da tradução espanhola de 1976, "Othon contra el doblaje", publicada em Manuel Asín (ed.). Jean-Marie Straub y Danièle Huillet - Escritos. Intermedio, fevereiro de 2011. Tradução de Calac Nogueira.

${ }^{17}$ E, “(Sur) prender a vida é também (sur) prender o ruído, (sur) prender no instante da voz”. Straub faz um jogo de palavras com sorprender e prender - surpreender e prender, para se referir ao enclausuramento perceptivo que somos submetidos com a exclusão de determinados sons da paisagem. Muito próximos do significado de escotomização de Chion, Straub-Huillet também consideravam os sons objetos significantes fundamentais para o homem e, que teriam sido excluídos do nosso universo simbólico pelos meios de comunicação de massa. Para os cineastas é necessário resgatar uma experiência sonora com os rumores e os ruídos que estão contidos no mundo.
} 
p.93 $)^{18}$.

$\mathrm{Na}$ proposta de cinema materialista de Straub-Huillet a paisagem sonora tem uma importância fundamental por possuir as marcas específicas e um ritmo intrínseco dos lugares. É a paisagem quem dita qual o plano que deve ser feito para capturá-la; a invenção deve ser reduzida ao mínimo e abrir-se ao acaso ${ }^{19}$. Em um de seus filmes (Da nuvem à resistência, de 1979), vemos e ouvimos de costas dois personagens conversando, em um longuíssimo plano, onde a filmagem está sempre "em risco de confronto com a natureza" (Adriano Aprà, 1992, p.194). A imagem e o som estão trepidantes, dentro do bloco de espaço-tempo que se encontravam os carros de bois e os deuses do Olympo. A experiência cinematográfica seria como uma abertura ao estranhamento, preenchida por uma espera física que percorre os caminhos do desvio, da errância, que nos afasta da procura falsa pela aparência. A paisagem passa, escutamos os sons que encarnam a vida, o ranger das rodas de madeira, a presença das nuvens. Em um determinado momento (numa longa seqüência em que os personagens falam de costas, assim como os cineastas parecem falar para o mundo) Tirésias olha para paisagem e fala para Édipo que "as coisas do mundo são rochas, estavam aqui muito antes dos homens e dos deuses, quando o mundo era só o mundo" ${ }^{20}$. Os sons, os sussurros, um suspiro de um personagem, a tremulação das vozes, as intrusões sonoras na rodagem, as mudanças de luz e as surpresas da vida fazem parte desse mundo, o modificam a cada instante. Em um mundo

\footnotetext{
${ }^{18}$ STRAUB-HUILLET; Ver p. 92-104. "Entrevista com J.M. Straub e D. Huillet - Sobre o Som”. Cátalogo da Mostra STRAUB-HUILLET, 2012, CCBB. Tradução do francês de Bruno Carmelo, de trechos da entrevista publicada na revista de música italiana GONG e posteriormente na Cahiers du cinéma, "Entretien avec J. M. Straub et D. Huillet - Sur le son", números 260, 261, outubro e novembro de 1975. Para Straub filmar som direto significa montar de uma maneira específica, "não se pode brincar com as imagens: existem blocos com certa duração e nos quais não se pode meter a tesoura assim, por prazer, para fazer efeitos". Para Huillet, "É justamente a impossibilidade de se enganar na montagem que é encorajadora. Não se pode montar o som direto como se montam filmes em que vai existir dublagem: cada imagem tem um som e nós temos que respeitá-lo. Mesmo quando o enquadramento é vazio, quando o personagem sai de quadro, não dá pra cortar, porque nós ainda escutamos, fora-de-quadro, o ruído dos seus passos se afastando".
}

19 APRÀ, Adriano; Ver p-193 a 196, catálogo STRAUB-HUILLET, 2012. "Prefácio a um volume de Textos Cinematográficos de Straub e Huillet", publicação original 1992.

20 Da Nuvem à Resistência (Dalla nube alla resistenza, 1979) foi projetado na mostra Straub-Huillet, em 2012, no cinema do $\mathrm{CCBB} / \mathrm{SP}$. 
onde se acreditava numa concepção materialista dialética, as relações de produção determinavam todas as outras produções que existem entre os homens na sua vida social, portanto, os filmes deveriam respeitar a paisagem que ali já existia, mesmo que este lugar esteja em ruínas.

\subsubsection{A "escotomização" do ouvido-microfone no cinema}

No cinema comercial contemporâneo, os sons são retirados (captados e fixados em um suporte) do ambiente acústico real para serem remodelados e organizados nos processos de edição e de mixagem; transformados em sons que, por vezes, podem alterar ou reforçar a significação dada às imagens cinematográficas. Para realização dos processos de gravação, edição e mixagem, os profissionais de cinema, geralmente, dividem os sons em diferentes tipos. As vozes (diálogos), os sons ambientes (background sounds), os sound effects (sons específicos e pontuais e, neles também se incluem os foleys - sons gravados em estúdio) e a música são articulados e tratados de maneiras distintas. Tradicionalmente, as vozes do diálogo são verificadas e, se não estão inteligíveis, são regravadas no processo de dublagem para que se tenha certeza da sua audibilidade. Ainda assim, no processo de pós-produção a voz é destacada pelo aumento da sua intensidade, como uma garantia de que o texto dito pelos atores seja bem compreendido nas salas de cinema. As intrusões sonoras espontâneas e os efeitos de ressonância do ambiente da filmagem que revelam o uso do microfone, por sua vez, também são controlados na tentativa de resguardar a inteligibilidade dos elementos sonoros, principalmente do diálogo (texto).

Nestes filmes, a maneira como se estrutura os sons mantêm vivo um acordo com as 
convenções de reprodução sonora pelas práticas técnicas de "escotomização" do microfoneouvido do espectador. A "escotomização" é um termo de origem complexa na teoria psicanalítica e que o crítico francês Michel Chion toma de empréstimo do psicólogo de Édouard Pichon ${ }^{21}$. Segundo Chion (1999, p.116), durante a maior parte do tempo, escotomizamos nossas próprias percepções sonoras privilegiando os sons diretos (em detrimento dos sons reflexionados), com o intuito de extrair o "sentido" de um sinal acústico. Inabarcáveis e foracluídos da simbolização dos espectadores, os ruídos tornaram-se na linguagem cinematográfica sinônimos de sons que podem representar momentos do acaso (BURCH, 1992) ou enfatizar um momento de tensão através da permanência de sensações causadas em ambiente sonoros e situações de ritmo, com velocidades diversas construídas dentro das cenas. No seio desta perspectiva, nos filmes de Lucrecia Martel, por muitas vezes, sentimos que os ruídos são usados para destacar acontecimentos bruscos e acidentais, mas também se destacam através da representação da interiorização da escuta. Personagens escutam sons inaudíveis e invisíveis que estão relacionados com os seus pensamentos, afetos e emoções.

${ }^{21}$ C.f. ROUDINESCO, Elisabeth; PLON, Michel. Dicionário de Psicanálise; Tradução Vera Ribeiro, Lucy Magalhães; Supervisão da Edição Brasileira Marco Antônio Coutinho Jorge. Rio de Janeiro: Zahar, 1998, p. 245. Ver termo Foraclusão (Verwerfung). Na obra "Des Mots à la pensée. Essai de Grammaire de la Langue Française", Edouard Pichon introduzia na França, o termo "escotomização" para designar o mecanismo de enceguecimento inconsciente pelo qual o sujeito faz desaparecerem de sua memória ou sua consciência fatos desagradáveis. Em 1925, uma polêmica opôs Freud a René Laforgue a propósito dessa palavra. Laforgue propunha traduzir por escotomização tanto a renegação (Verleugnung) quanto um outro mecanismo, próprio da psicose e, em especial, da esquizofrenia. Freud recusou-se a acompanhá-lo e distinguiu, de um lado, a Verleugnung, e de outro, a Verdrangung (recalque). A situação descrita por Laforgue despertava a idéia de uma anulação da percepção, ao passo que a exposta por Freud mantinha a percepção, no contexto de uma negatividade: atualização de uma percepção que consiste numa renegação. Posteriormente, em 3 de fevereiro de 1954, Lacan começou a atualizar a questão do foraclusivo e da escotomização, por ocasião de um debate com o filósofo hegeliano Jean Hyppolite (1907-1968), ele próprio confrontado com essa questão por intermédio da Verneinung, a qual propunha traduzir por denegação, em vez de negação. Lacan inspirou-se no trabalho de Maurice Merleau-Ponty (1908-1961), Phénoménologie de la perception, e, sobretudo nas páginas desse livro dedicadas à alucinação como "fenômeno de desintegração do real", componente da intencionalidade do sujeito. 


\subsubsection{Percepção bi-sensorial sonora: Co-Vibração e Janela Auditiva}

Com uma retro-alimentação auditiva particular - a ergo-audição ${ }^{22}$, os seres humanos são emissores e receptores auditivos dos mesmos sons que refletem em todas as direções no espaço. Ouvimos desde o nosso interior (por co-vibração dos sons) ao nosso exterior (através da janela auditiva de nossa orelha e da co-vibração dos sons internos), porém com a passagem da infância para a fase adulta percebemos menos as reflexões dos sons e tornamo-nos menos conscientes dos ruídos que emitimos. Segundo Chion (2011, p.77), a escotomização do papel do microfone acontece com a exclusão dos seus efeitos significantes (os ruídos e as distorções decorrentes da amplificação) do campo consciente do ouvinte. No cinema, lugar onde ouvimos a voz e os sons internos do outro, o microfone deve permanecer excluído não só do campo visual e sonoro como também da representação mental do espectador. Para o autor, uma concessão naturalista teria permanecido apegada ao som, mesmo após as discussões da teoria cinematográfica dos anos 60 e 70 terem contestado a idéia de "transparência" da imagem e de uma ilusão unitária entre o som e a imagem.

assim, esta conceção muito corrente, evocada no capítulo anterior ${ }^{23}$ e a que podemos chamar de naturalista, postula à partida uma harmonia natural entre os sons e as imagens, e admira-se por não a encontrar no cinema, atribuindo

\footnotetext{
22 Tradução própria. "Hay, por tanto, ergoaudición cuando el oyente es al mismo tiempo, total o parcialmente, el responsable, consciente o no, del sonido que oye. [...] En esta situacion se produce un feed-back particular queen ausencia de descondicionamiento aprendido - es susceptible de influir sobre el emissor al respecto da natureza del sonido que emite o controla" [...] "Independientemente de su descubrimiento, no parece plantearse ninguna cuestión sobre la complejidad del "oírse hablar", que no solamente articula uma voluntad y un efecto, sino tambiém unas percepciones externas y una percepción interna que, aun cuando se vinculen, no se fusionan”. CHION, M. “El Sonido: música, cine y literatura...”. Barcelona: Páidos, 1999, p. 114,117.

${ }^{23}$ O capítulo anterior do livro "Audiovisão", o qual Chion se refere trata da delimitação espacial do som pela imagem. Segundo o autor, em “A Cena audiovisual” (2011, Capítulo 4, p.57-77) a localização espacial do som é delimitada no cinema pela localização da imagem da sua fonte e as relações entre campo e fora-de-campo são construídas por um fora-de-campo mais mental do que físico, a partir das conexões que o espectador estabelece entre som, imagem e a narrativa. Como exceção à essa regra, o autor aponta o exemplo da música de fosso "àquela que acompanha a imagem a partir de uma posição off, fora do local e do tempo da ação" (CHION, 2011, p. 67). Neste sentido, o autor levanta a ideia de que a referencialidade do som à imagem seria responsável pela concretização de um ideal de "transparência" do som, ideal que em relação à imagem é questionado pela teoria de cinema desde a década de 60.
} 
isso a uma falsificação técnica na realização. Se nos contentássemos em captar tal e qual os sons da rodagem sem os alterar em nada, talvez encontrássemos essa unidade. (Chion, 2011, p.79)

Na maioria dos casos, nos processos de captação e pós-produção os sons são escumados de certos ruídos e enriquecidos com outros. Nas filmagens, a direcionalidade do microfone também é determinada a fim de evitar as fissuras e os efeitos disruptivos na percepção do espectador. Chion aponta que tais concessões da linguagem cinematográfica são reforçadas pelas práticas de técnicas de reprodução sonora de isolar e dominar o som (idem, ibidem, p.81-85). Nas salas de cinema e nas produtoras de edição e mixagem procura-se tornar $o$ som o mais limpo possível, purificando-o e tornando-o potente e definido. Os equipamentos de alta-fidelidade sonora ( $h i-f i$ ) desenvolvem, cada vez mais, mecanismos adaptados para que os ouvidos fiquem protegidos dos ruídos e das intrusões sonoras no cinema. O ouvido do espectador deve habitar um lugar estável, seguro, plano e contínuo, que o deixe percorrer facilmente os caminhos da narrativa.

Neste sentido, falar que a cadeia de alta-fidelidade sonora (amplificadores, transistores e etc.) e a materialidade física do som no cinema produzem efeitos sonoros que podem controlar o universo simbólico do espectador, seria reduzir o som a uma reificação ${ }^{24}$. Ao contrário, Michel Chion demonstra no livro "El sonido" (1999), a partir de dez motivos por que a reificação de um som não pode ser possível. O músico concreto recusa considerar o som como um objeto da percepção que pressupõe uma causa e consequência (efeito) natural. O primeiro motivo elegido por Chion acontece com a revelação da ambiguidade do termo som.

\footnotetext{
24 "Réifier. Verb transitif. (du latin res, rei, chose).Reificación (nom féminin réifier). En philosofie, processus par lequel on transforme quelque chose de mouvant, de dynamique en être fixe, statique. Transformation effective d'un rapport social, d'une relation humaine en "chose", c'est-à-dire en système apparemment indépendant de ceux pour lesquels ce processus s'est effectué". (Le concept de réification est dû à Marx; mais el a été surtout développé par Lukács.) Larousse Dictionarie Online. "Reificação em português é descrito como o processo em que uma realidade humana ou social perde ou parece perder seu dinamismo e passa a apresentar a fixidez de um ser inorgânico, com perda de autonomia e, no caso do homem, de autoconsciência; Coisificação [ O conceito foi desenvolvido pelo filósofo George Lukács (1885-1971), tendo em mira uma crítica aos mecanismos do sistema capitalista]". [plural: - ções], [F.: reificar + -ção. Cf.: alienação.]. Dicionário Online de Português Caldas Aulete.
} 
Com a definição da "Encyclopédie de la Musique et Dicionnaire du Conservatoire de Lavignac", Chion (idem, ibidem, p. 61) descreve que o som funde-se entre um fenômeno objetivo, onde propagação e a reflexão do som são consideradas como a "causa" de sensações sonoras e um fenômeno subjetivo - não existente fora do corpo do sujeito, e por isso, dependente da sua subjetividade.

No primeiro longa-metragem de Lucrecia Martel (O Pântano, 2001) os ruídos de taças, latidos de cachorros, sons de trovões, ruídos de panelas são usados para conferir ritmos sonoros diferentes às cenas, mas também são abarcados através de uma ambiguidade de sentidos para dentro do campo simbólico dos personagens. Como exemplo, destaco os latidos de cachorro ouvidos através do muro do vizinho da personagem Tali, e que ao longo do filme, sofre uma alteração de sentido. A história popular contada por uma das adolescentes às voltas da piscina e ouvida pela criança Luchi (filho mais novo de Tali) nos fala sobre como uma rata-africana selvagem é confundida com um animal doméstico. No final do filme, a anedota pode ser compreendida como um anúncio, um sinal. A precipitação de uma tragédia é anunciada através daquilo que é exposto como muito familiar e que pode adquirir um sentido mais assombroso e selvagem. Os sons internos de Luchi, ou seja, aquilo que o amedrontava intimamente no seu pensamento ganha força, torna-se externo após a escuta desta lenda oral. Na cena final desta película, o mesmo latido de cachorro percebido em cenas anteriores como um ruído banal, concretiza-se a partir da sua variação como um ruído ameaçador e mortal.

No segundo longa-metragem da cineasta, ouvem-se gritos e conversas contínuas que reverberam nos corredores de um hotel, além da presença constante dos sons de água. Em $A$ Menina Santa, os sons surgem do espaço fora de campo para revelar a paisagem sonora de um mundo em constante movimento e transformação através dos ouvidos da adolescente Amália (Maria Alché) e, especialmente, “os murmúrios e os diálogos à meia voz criam uma dimensão 
significante que não tem nada a ver com o sentido das palavras" ${ }^{25}$ (AGUILAR, 2010, p.95). Estes sons, distantes de uma compreensão semântica, acentuam uma sensação deliquescente e conferem uma atmosfera perturbadora ao filme. Uma perturbação que aparece somente quando os sons são ocultados. Amália (Maria Alché) escuta um chamado divino, voz interior e inaudível de Deus que oferece a ela uma missão. Sua mãe (Helena, interpretada por Mercedes Morán) é afetada pela Síndrome de Menière e perturba-se com a variação de intensidade e tons de um zumbido sibilante provocado por ruídos inaudíveis. A doença, especialidade do médico otorrino Dr. Jano (Carlos Belloso), é definida como um complexo de sintomas com causa desconhecida e pode afetar a audição e o equilíbrio. Desse modo, repleto de eventos sonoros que comentam a narrativa, a representação de uma experiência da escuta de sons acusmáticos pelos personagens concretiza-se numa tensão auditiva; uma desordem perceptiva provocada em ouvir sons invisíveis e inaudíveis.

\footnotetext{
25 Tradução minha. "los murmullos y los diálogos a media voz crean uma dimension significante que no tiene nada que ver con el sentido das palabras". (idem, ibidem, p. 95)
} 


\section{Capítulo 2 - O ouvido como instrumento de subjetivação do som nos filmes}

\section{de Lucrecia Martel}

Para a cineasta Lucrecia Martel, o pensamento sonoro acerca das suas películas acontece previamente às filmagens, guiando-a nas escolhas para captação e organização do material: "Primeiramente, escolho certa tonalidade sonora que dará identidade ao filme e que me guia nas escolhas cotidianas da encenação"26. Em entrevista a Jean Michel Frodon, por ocasião da participação do filme A Menina Santa (2004) no festival de Cannes, Martel completa a frase comentando sobre o seu processo de criação: "e de resto, eu decido diariamente, já tendo feito algumas escolhas prévias"27.

Em "Dangereuse jeunes filles", crítica publicada junto à entrevista na Cahiers $d u$ Cinèma (setembro de 2004, n.593), Mia Hansen-Love destaca algumas marcas estilísticas presente no filme $O$ Pântano, 2001, que ressurgem no filme A Menina Santa. Segundo Hansen-Love, no segundo filme da cineasta a presença de uma lúgubre dança das gerações entre mães e filhas; certo deslizamento entre a languidez juvenil e um estado de morbidade causado por acúfenos e acidentes; além da insistência no uso da piscina como um elemento central, promovem uma sensação de constante proximidade e foram as mesmas marcas estilísticas que conferiram um tom estridente (le ton grinçant) $)^{28}$ ao filme $O$ Pântano

\footnotetext{
${ }^{26}$ Tradução minha. "J'ai d'emblée en tête une certaine tonalité sonore, qui donnera son identité au film, et me guide dans le choix quotidiens de mise-en-scène". Trecho de uma entrevista da cineasta Lucrecia Martel concedida à Jean Michel Frodon, por ocasião da cobertura do Festival de Cannes no ano de 2004. "Le cinema comme espace collectif", Cahiers du Cinema, n. 593, p.31, setembro de 2004.

${ }^{27}$ Idem, ibidem, p. 31. "pour le reste, je décide chaque jour, mais en ayant fait quelques choix à l'avance". Na entrevista, entre as escolhas feitas previamente às filmagens de A Menina Santa, foram destacadas pela cineasta: a preferência em trabalhar com planos mais curtos, a opção de estabilizar o quadro com o uso da câmera fixa e o uso de lentes objetivas de $50 \mathrm{~mm}$ e $70 \mathrm{~mm}$ para trabalhar a profundidade de campo.

${ }^{28}$ C.f. HANSEN-LOVE, Mia. "Dangereuses jeunes filles", CAHIERS DU CINÉMA, Septembre 2004, n. 593, p.30. "L'orientation est restée la même: mais em approfondissant l'univers de La Cienaga, La Nina Santa peu à
} 
(CAHIERS, 2004, p.30).

Com efeito, gostaria de destacar como as palavras tonalidade (tonalité) $e$ tom (ton) aparecem nestes dois discursos, da cineasta e da crítica, associando-se a uma tensão estridente. No discurso da cineasta a palavra tonalidade aparece relacionada à experiência de uma pré-escuta, como se fosse uma sonoridade específica imaginada pela cineasta e, segundo a qual, definirá suas escolhas de encenação. Enquanto no discurso da crítica, a palavra tom aparece associada à qualidade sonora da estridência, adquirindo o sentido de uma fricção entre os vários elementos estilísticos presentes nas obras de Lucrecia Martel.

No seu processo de criação, podemos apontar que o uso do som dá-se sob a premissa de uma dupla-pertença expressiva através da incorporação de suas qualidades sonoras (ritmos, intensidade, textura e timbre) e de sentidos diversos (semânticos, causais ou figurativos) em relação aos valores da imagem da fonte sonora. Essa dupla-pertença do som ressurge neste capítulo com a proposta de uma experiência de pré-escuta da cineasta para, num segundo momento, apontarmos através da análise fílmica como os sons são usados para representação da experiência auditiva dos personagens do seu último longa-metragem, A Mulher Sem Cabeça (2008).

A preferência em iniciar a análise pelo seu último longa-metragem produzido, deu-se a partir da escolha de um tema e não de uma ordem cronológica da sua produção. Em A Mulher Sem Cabeça, o tema do "esquecimento de um acontecimento" (BARTHES, 1997) dado na narrativa e revelado somente por sons nos conecta diretamente ao tema tratado no primeiro capítulo.

O esquecimento da significação dos sons referido através do termo acusmático

peu déparé d'une certaine outrance stylistique qui pesait sur l'autonomie des choses montrées. On assiste de nouveau, en un seul lieu ou presque, à une danse des genérations, danse frisant le macabre et que Martel orchestre virtuosement. Cependant, le frottement du vierge au dégradé, le glissement de la langueur juvénile à la morbidité et vice versa, qui donnaient le ton grinçant de La Cienaga, cèdent peu a peu la place à un intérêt plus posé pour la mécanique sexuelle d'une jeune héroine. Amalia conduit l'histoire en canalisant l'énergie dispersée de Martel”. 
(SCHAEFFER, 1988; SCHAFER, 2001; CHION, 2011) aparece como motivo central desta análise que destaca o ouvido dos personagens para depois adentrar no universo de representação das várias casas retratadas nos filmes de Lucrecia Martel.

\subsection{As práticas e as maneiras de incorporação dos sons}

Ainda na etapa de pré-filmagem, como uma das práticas de incorporação dos sons nos filmes, a cineasta e o diretor de som Guido Berenblum reúnem-se para definir as qualidades sonoras dos objetos que serão usados em determinadas cenas ${ }^{29}$. Os objetos de cena são escolhidos pela sua textura plástica sonora, priorizando qualidades perceptivas dos sons produzidos com a água, com o vidro e com alguns metais. Provenientes de objetos do cotidiano dos personagens, alguns sons foram escolhidos neste primeiro momento através da incorporação de texturas semelhantes com o intuito de definir certa variação da sonoridade, ligada a uma lógica interna do filme. Para Berenblum (2008), presente na gravação dos três longas-metragens da cineasta, com a utilização de objetos sonoros do cotidiano dos personagens produz-se, além de uma definição da sonoridade geral, uma manera de $\operatorname{acercarse}^{30}$ do universo de representação dos filmes de Martel. Um personagem ou uma situação podem estar identificados com um som específico e a partir da variação desse som (com o mesmo som ou outro som que tenha qualidades sonoras semelhantes) podem-se alterar os valores das imagens ao longo do filme.

\footnotetext{
${ }^{29}$ Para maiores informações sobre as conversações entre o diretor de som e a cineasta, ler a entrevista com Guido Berenblum incorporada em anexo a esta dissertação.

${ }^{30}$ Termo cunhado pelo diretor de som Guido Berenblum, na entrevista "Charla com Lucrecia Martel y Guido Berenblum”, 2008, Cátedra SEBA/FADU. Guido explica em entrevista que trata-se de comentar sobre como o som foi usado para construir uma maneira de aproximação do universo ficcional dos filmes, com determinados personagens identificados por determinados objetos que produzem som na cena.
} 
Pode-se apontar como uma das consequências desta prática de experimentação dos sons diegéticos, a identificação de personagens e cômodos da casa com algumas situações de escuta dos sons específicas. No primeiro trabalho desenvolvido entre Martel e Berenblum, $O$ Pântano (2001), o roteiro estava recheado de descrições sonoras e o trabalho do técnico de som direto consistiu em concretizar a percepção auditiva desse ambiente narrado. $\mathrm{Na}$ busca da construção de um estilo sonoro, estabeleceu-se um "modo de aproximação" dos objetos em cena com a criação de uma lógica de ambiguidades em relação à causa da fonte sonora.

A partir da plasticidade sonora dos objetos criou-se um jogo entre os objetos da casa de Mecha que tinham texturas sonoras semelhantes - o trovão no ambiente externo da casa produz uma sonoridade mais grave, pesada, e que pode ser confundida com o som grave de uma porta enferrujada, de um dos cômodos da casa. Também alguns personagens da trama aparecem em cena sempre delineados pelas qualidades sonoras dos objetos: Mecha sempre aparece acompanhada de um copo de vinho com gelo e seu som específico anuncia sua chegada nos ambientes. Na cozinha de Tali, todos os personagens sempre aparecem sob os efeitos auditivos da algazarra das crianças, à exceção de uma das cenas finais na qual o silêncio aparece instaurado por um acidente mortal.

Muitos dos sons usados em $O$ Pântano aparecem como elementos expressivos de brusca irrupção, ruídos que pela sua intensidade e plasticidade criam uma percepção estridente, penetrante; enquanto outros sons emergem a partir do silêncio dos personagens para que se possa ouvi-los numa escala de percepção global sutil, ressaltando a sonoridade dos mínimos detalhes do cotidiano, os murmúrios e as respirações dos personagens.

Na etapa de filmagem, o conhecimento das texturas dos sons e a definição das suas funções na narrativa - se para provocar um forte estrondo, uma interrupção na fala ou mesmo para revelar mais da intimidade dos corpos com ruídos fisiológicos - foram determinantes para a realização de uma captação do som que empregava diferentes enquadramentos e 
distâncias entre o microfone e a fonte sonora. Objetos e personagens tinham seus ruídos e vozes captados com diferentes distâncias e angulações do microfone o que proporcionou uma possibilidade maior de combinação e variação destes sons no processo de pós-produção.

Dada a possibilidade do uso de materiais com texturas semelhantes, da organização dos sons em função da narrativa e em relação às imagens, no decorrer dos filmes a repetição e a variação dos sons podem exercer ainda uma função na ativação da memória auditiva dos espectadores, conferindo um valor significante ao som nestas películas. Por sua vez, nas filmagens de A Menina Santa, a captação do som direto concentrou-se na cobertura de vozes e ruídos do entorno do espaço da filmagem, no interior dos grandes corredores do hotel Termas de Rosário de la Frontera. Essa cobertura de som, posteriormente mixada nos canais surround (laterais e fundos da sala), serviu para construção de um espaço fantasmagórico, ambiente de vozes e sons nunca visualizados pelo espectador que confere certa variação de ritmos e tons para determinadas cenas.

Priorizando ruídos mínimos - como as pontuais gotas da chuva, a respiração de um personagem - ou os sons estrondosos e espessos de um trovão que interrompe uma fala em cena, a cineasta também se utiliza da reiteração de padrões sonoros para criar uma atmosfera de estranheza familiar aos espectadores e personagens. Contudo, procuramos destacar a criação de uma banda sonora experimental que se utiliza de ruídos diegéticos para destacar as emoções, afetos e outras figuras ficcionais através de motivos sonoros que se repetem e confundem a percepção sonora dos ouvintes. Optando por um jogo paradoxal entre significantes ruidosos e a perda da referencialidade dos sons, a cineasta apresenta nos seus filmes sons cotidianos que ao serem reiterados modificam os sentidos da imagem apresentada. Intrigados com sons que aparecem no dia-a-dia, os personagens parecem ser molestados por ruídos e deixam escapar seus significados. Um latido de cachorro ou os ruídos provocados por um theremin podem ser metáforas para algo monstruoso que se esconde no cotidiano e repete- 
se longe da vista dos personagens como se quisesse ser trazido para o universo simbólico. Os personagens incapazes de lerem estes sinais sonoros, somente podem sentir através dos seus corpos um incômodo transmitido para os espectadores através de uma gestualidade lânguida e angustiada. Sem se haver com o significado real dos sons apresentados nas narrativas, os personagens experimentam uma escuta que abarca alterações rítmicas e melódicas não representáveis, momento de puro deleite temporal de um espaço subjetivo, inacessível aos olhos e ao pensamento.

\subsection{A representação de um modo de escuta contemporâneo do som}

No longa-metragem A Mulher Sem Cabeça (2008), uma mulher após sofrer um acidente vê-se diante da necessidade de esquecer para depois lembrar. Neste filme, a partir da representação de uma situação acusmática experimentada pela protagonista percebem-se pequenos eventos sonoros, ruídos invisíveis e, por vezes, inaudíveis que molestam o cotidiano da personagem e podem revelar outro mistério da narrativa: a experiência e o estranhamento em ouvir-se internamente, a ergo-audição. Em conjunção as escolhas de mise-en-scène presente nos dois primeiros filmes dirigidos pela cineasta, O Pântano (2001) e A Menina Santa (2004), pretendo apontar no texto como os sons provenientes do espaço fora-de-campo (acusmatizados) são usados para apresentar a idéia de um "acontecimento de esquecimento" (BLANCHOT, 2007).

No pensamento schaefferiano (1988), a situação acusmática é apresentada como uma experiência de "suspensão", que promove por si mesma uma escuta reduzida. Com o isolamento do "objeto sonoro em si" pode-se experimentar um modo de escuta para 
contemplação dos sons do mundo, uma experiência que não se produz no "jogo dos números e nos segundos do metrônomo, mas com pedaços de tempo arrancados do cosmos" (SCHAEFFER apud MENEZES, 2009, p.20). Enquanto modelo temporal, Schaeffer apontou a periodicidade dos sons como um procedimento de repetição do ruído para produção e variação de formas sonoras e musicais. Com um pensamento relacionado à fenomenologia, Pierre Schaeffer lança dúvida sobre os limites que definem o sujeito e o objeto na experiência auditiva, baseando-se na negação da existência de uma percepção fora da consciência. Conforme Obici (2008), Schaeffer propôs um modo de escuta que considera o som como existente dentro e fora da nossa consciência, a partir do momento em que o percebemos (OBICI, 2008, p.28).

Na música concreta, o ouvido como modelo temporal estaria sempre marcado por uma dupla pertença do som, não apenas compreendido como instrumento receptor de um som "externo" (fora da nossa consciência), mas um som que se faz "interno" ao existir na nossa consciência. Como vimos, na experiência cinematográfica os sons nos fornecem uma escala de percepção global e, de certo modo, pode nos paralisar impedindo de ouvir outros sons,e, também pode nos colocar em estado de alerta.

Nas análises de Gonzalo Aguilar e Mia Hansen-Love sobre os filmes da cineasta Lucrecia Martel, os sons foram destacados por diversos sentidos e significados. Para Aguilar (2010), sons audíveis, inaudíveis e invisíveis criam uma atmosfera significante distante do sentido das palavras. Mia Hansen-Love (2004) prefere se distanciar das palavras e vozes para lembrar a presença da água da piscina e outros elementos do ambiente que conferem uma sensação aquosa de proximidade. Contudo, na experiência de escuta destes filmes, os ruídos que escutamos seriam os mesmos percebidos pelos personagens? Eles escutariam esses sons conscientes ou inconscientemente? A partir destas questões, destaco a presença de uma situação de escuta acusmática apresentada no início do filme A Mulher Sem Cabeça. Nesta 
película, uma ameaça sonora prolonga um acontecimento acidental e confere uma sensação de dúvida até o final da narrativa.

Logo, numa das primeiras cenas do filme, de dentro do carro vemos uma estrada cheia de curvas e montanhas distantes. Sem diálogo, o silêncio dá aos ouvidos o som do atrito dos pneus em contato com o chão terroso. Ouve-se também uma música de Nana Mouskouri que toca na rádio do carro Soleil, Soleil, uma melodia alegre e popular dos anos 70 . O plano, que antes mostrava um ângulo de visão frontal, é substituído por um plano lateral mais fechado, mostrando o perfil de Verônica (Maria Onetto) dirigindo. Verô é a única pessoa presente na imagem e, nós, espectadores, a olhamos de muito perto, ao seu lado, do ponto de vista do passageiro. Vê-se através do espelho do carro, o seu rosto, a passagem rápida de galhos secos e uma vegetação rasteira encoberta pela poeira da estrada. Um ruído virtual surge, parece com o toque de um celular. Verônica abaixa-se para buscá-lo (o celular) na bolsa e não vemos mais o seu rosto. Ouve-se um estrondo, um solavanco no automóvel como o produzido por um atropelamento. O carro é parado, o atrito do pneu do carro desaparece e a mulher resta imóvel por um tempo que é o necessário para percebermos duas pequenas manchas no vidro do carro, o rastro de uma delicada mão infantil. Ainda ouvimos o telefone e a música que tocam por mais alguns segundos até o momento em que Verônica pega um óculos, liga o carro e resolve seguir adiante. O silêncio se estabelece e pela imagem refletida no retrovisor do carro vemos, em frações de segundos, o que parece ser o reflexo de um cão estirado e encoberto pela poeira da estrada (figuras 1, 2, 3, 4 e 5). 


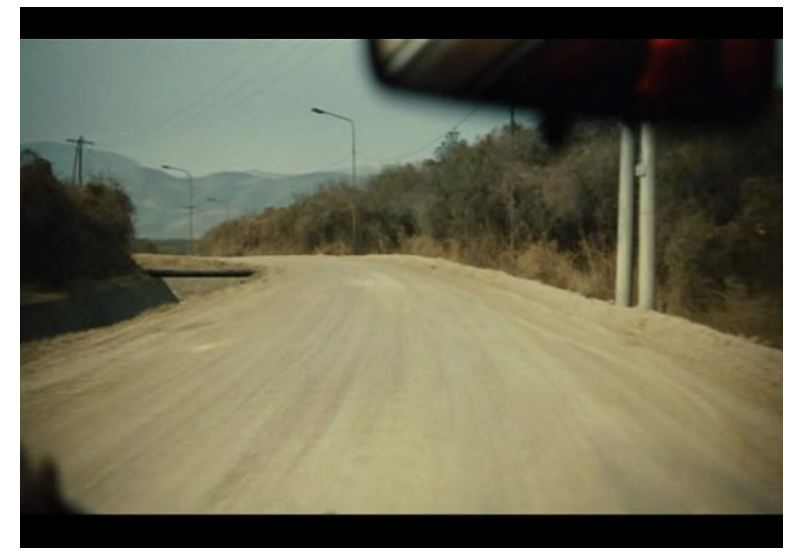

Figura 1.

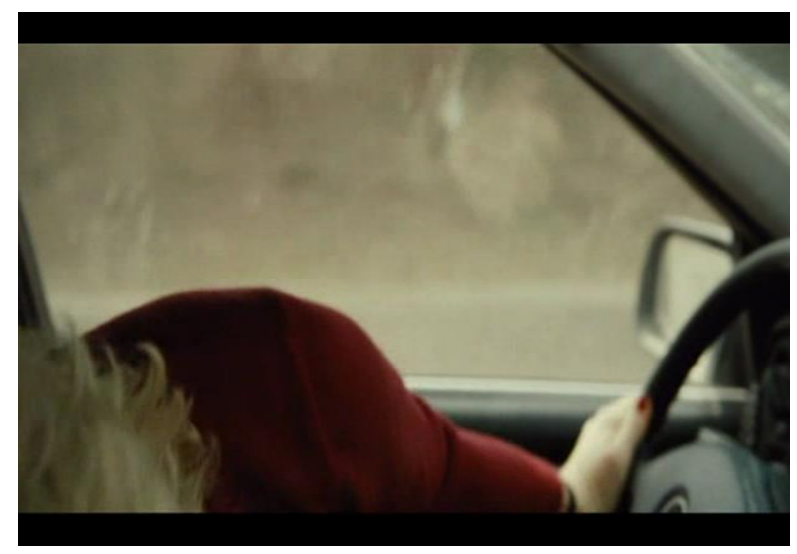

Figura 3.

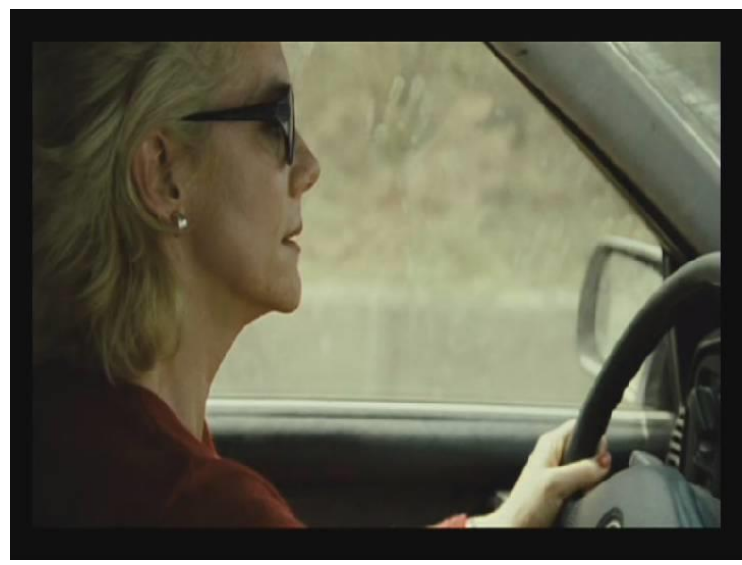

Figura 2.

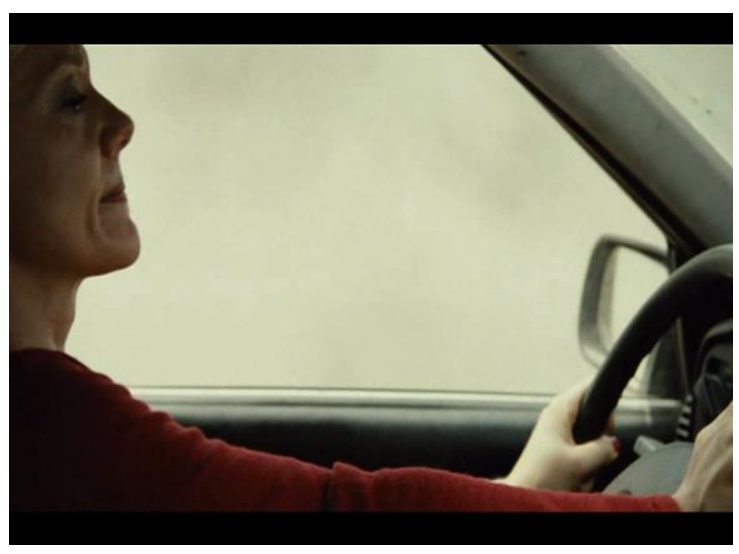

Figura 4.

Figura 5.

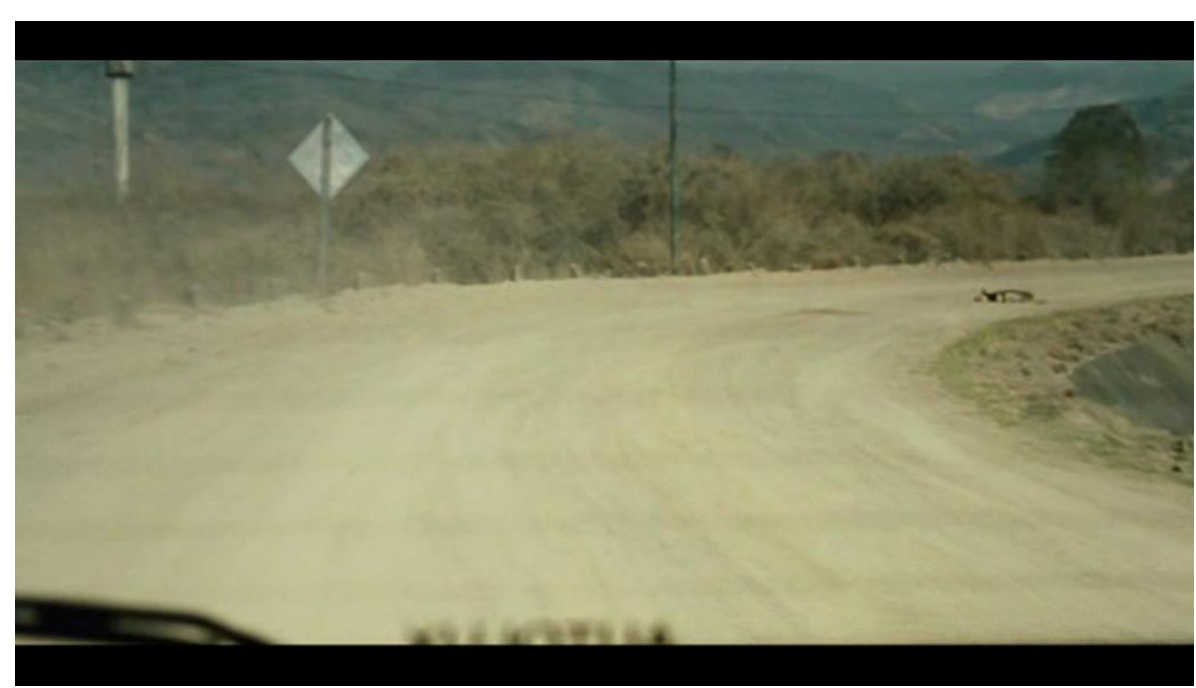


A mulher matou um cão ou uma criança? O rastro das mãos seria da criança atropelada ou da criança que aparece presa dentro do seu carro, ainda nos primeiros minutos do filme? Não saberemos nunca, pois a ação desta cena acontece no espaço fora de campo e só a imaginamos pelo impacto de um som acidentado e trêmulo. Nas imagens e ações da personagem posteriores só reforça-se uma sensação de dúvida. Nesta cena, temos um som de sustentação acidentado e trêmulo que cria uma atenção tensa e imediata sobre a imagem, colocando o espectador em estado de alerta pelo seu caráter de impacto descontínuo. O som do impacto do acidente e a imagem da não reação de Verônica surgem como um contraponto à música alegre de Nana Mouskouri. Tal contraposição dada pela articulação entre a imagem do acidente e a música parece tentar nos adiantar outra ironia: de que por detrás da imagem apaziguadora do cão atropelado poderá ressurgir a qualquer momento uma tensão contrária, uma fissura na imagem que indique a morte de uma criança. A personagem Verônica (Maria Onetto), após sofrer o choque acidental se encontra diante de um problema: um som externo que atingiu seus ouvidos se faz "interno" ao permanecer na sua consciência como lembrança de uma dúvida.

Ao longo do filme, a protagonista refaz os seus caminhos e descobrimos juntos, espectador e personagem, que certas evidências das suas ações foram apagadas, restando-lhe a opção do esquecimento. A ideia sobre o esquecimento permeia todo espaço da narrativa nos gestos lentos da personagem, na sua não reação verbal as conversas ou ainda, na insistência da cineasta em realizar enquadramentos que decepam a sua cabeça. Novamente, através da articulação entre posição corporal, movimentos e velocidades diferentes entre a imagem e a banda sonora, percebe-se a sensação de um tempo letárgico, do cansaço, da fadiga. Neste sentido, nesta terceira película da cineasta, podemos acrescentar que as interrupções dos ruídos representam sonoramente uma tênue e delicada tensão entre o esquecimento e a fadiga, 
como uma "tensão da memória" (BARTHES, 2007).

Resgatando uma lembrança barthesiana, outra ideia sobre o esquecimento é apresentada em "Fragmentos de um Discurso Amoroso" (2007), onde Roland Barthes pontua que todo episódio de linguagem que encena a ausência de um objeto para o ser humano coteja o seu esquecimento. Conforme o autor, "a ausência bem suportada nada mais é do que o esquecimento. Sou intermitentemente infiel. Esta é a condição de minha sobrevivência, pois se não esquecesse morreria. $\mathrm{O}$ amante que não esquece algumas vezes morre por excesso, cansaço e tensão da memória" (BARTHES, 2007, p.35). Neste sentido, relembro ainda outro evento sonoro desta película, onde o paradoxo entre esquecer para viver e o da memória como condição de morte se anuncia. Antes da cena do atropelamento, ainda sobre a imagem de crianças correndo dentro de um canal ouve-se um ruído metalizado. $\mathrm{O}$ pequeno estalido agudo e ritmado, aparentemente sem uma justificativa, retorna sobreposto ao som da chuva no final da sequencia do atropelamento (figura 6). Como um sinal da morte, esse som aparecerá diversas vezes, mas sempre nos momentos onde Verônica mostra-se isolada e parece rememorar o evento sonoro do acidente. Em outra cena, primeiro momento no qual a protagonista passa novamente pela estrada do acidente (figura 7), ouve-se novamente o ruído metalizado. A personagem sai do carro para buscar o tênis de um dos adolescentes que está dentro do carro, mas detém-se de costas para o quadro no momento em que se ouve o som. Verônica teria escutado esses sons conscientemente? Este som, o qual não visualizamos a sua fonte sonora pertence ao universo da narrativa ou é um ruído extra-diegético?

Assim como o espectador em relação à dúvida mortal do filme, não temos como responder exatamente essa pergunta. A dúvida será mantida, mesmo que o espectador assista novamente ao filme. Este som faz-se ambíguo pela sua repetição e variação da matéria sonora que produz diferentes sentidos e significados em relação a cada imagem e a cada momento que retorna na narrativa. Primeiramente, o som que surge do espaço fora de campo, é 
apresentado próximo a estrada onde se encontram apenas as crianças (figura 8) para, num segundo momento, surgir em outros momentos na mesma estrada onde houve o acidente. Molestada por ruídos que rememoram o acidente, a escuta da personagem seria colocada em “estado de espera". A figura da precipitação parece ser substituída pela figura do esquecimento ou ainda de um "acontecimento de esquecimento" (BLANCHOT, 2007, p.171) onde é necessário promover uma dilatação tempo da imagem para destacar cada acontecimento que se esquece. Sem afirmar ou negar, a personagem prefere esquecer a presença da morte, evitando a fadiga e o cansaço.

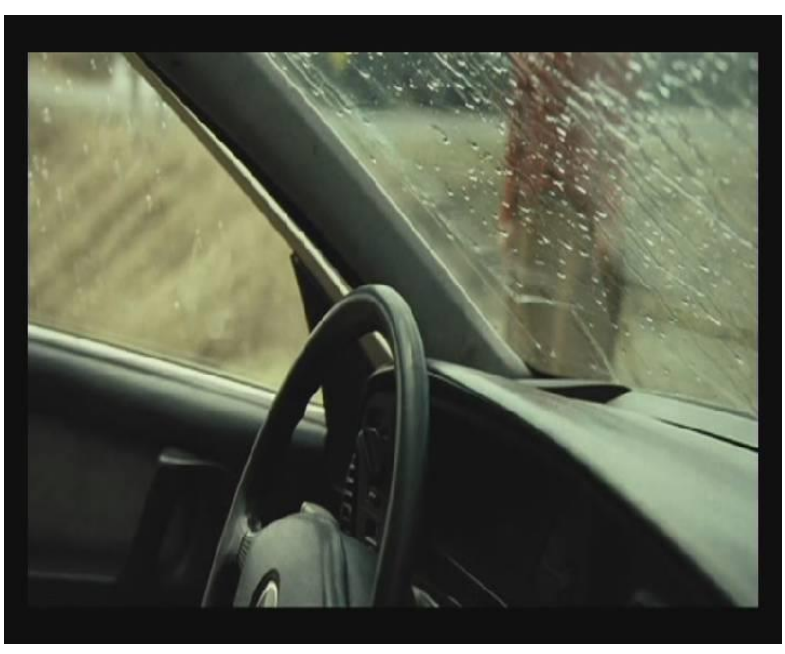

Figura 6.

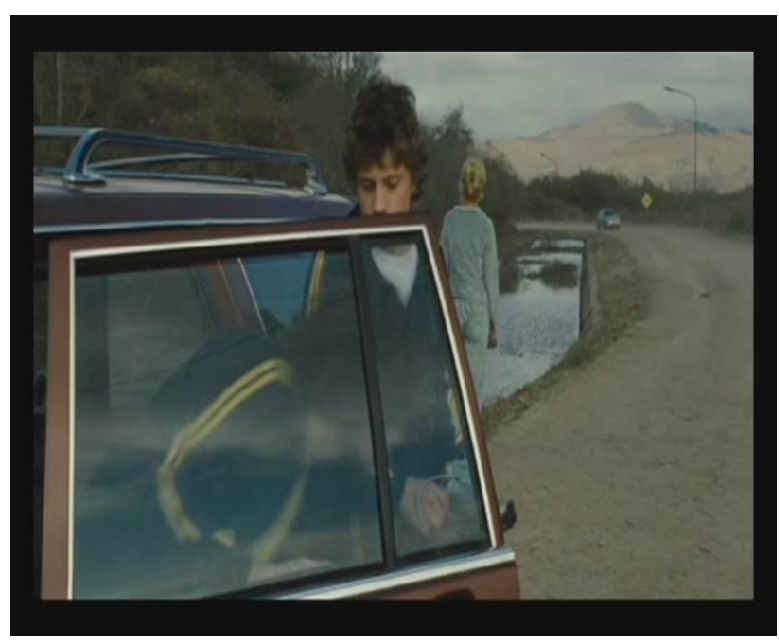

Figura 7. 


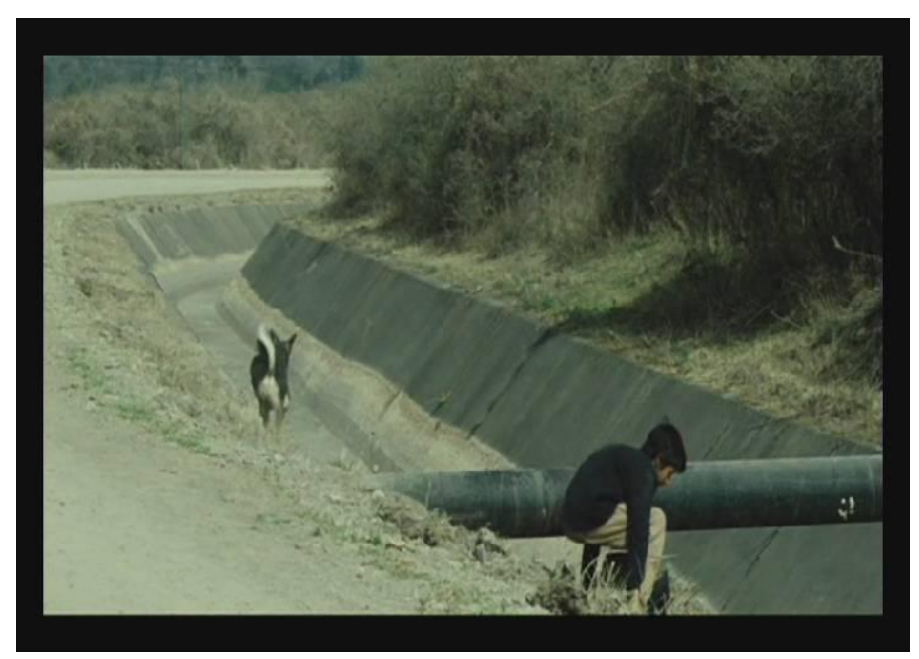

Figura 8.

\subsection{A partilha da escuta entre espectador e personagens: um modo de aproximação}

Até este momento, a ideia da fadiga e do esquecimento apareceu de forma significativa neste capítulo evocando diferentes acepções, mas sempre relacionadas à uma tonalidade estridente, impactante. No pensamento sonoro de Murray Schafer, a fadiga estaria presa dentro da evocação de um estereótipo sonoro da paralisia dos ouvidos. Na primeira parte desta dissertação, a experiência auditiva contemporânea da esquizofonia foi destacada da obra de Murray Schaefer por estar ligada a uma ideia de atrofia do pensamento. A presentificação dos ruídos na metrópole, a crise da sensibilidade humana são marcas de um mundo urbano e capitalista, ao passo que, a experiência de escuta de uma paisagem provinciana, do campo, seria a da audição dos sons mínimos, suaves, que não agridem e nem paralisam as conexões significantes com o mundo através de excessos de intensidade e fragmentação.

Mais adiante, em "A experiência acusmática como subjetivação do som", migrando da acepção de fadiga como um estado genérico de letargia, o esquecimento foi evocado na poética concreta schaefferiana pela sua condição de instrumento da escuta. Ao contrário de 
uma incapacidade, o esquecimento surge na acepção de uma degradação da linguagem musical, como uma experiência auditiva com sons acusmáticos que arrancam "pedaços de cosmos" e colocam os nossos ouvidos em estado de "suspensão". Na tipo-morfologia schaefferiana, o mascaramento dos sons provocado pelo excesso de ruídos no mundo urbano e industrializado se converte numa experiência positiva. O funcionamento da escuta a partir de situações geradas pela produção constante de sons disponibilizaria um estado de ligação e corte constantes nos fluxos sonoros, capazes de penetrar na percepção e descondicionar os comportamentos habituais de escuta (OBICI, 2008).

Mas, dentre todos os aspectos referidos e que se fazem diversos nas películas de Lucrecia Martel, é o tratamento dado à banda sonora o qual destaco com maior relevância em relação à construção da mise-en-scène. O tratamento dado ao som nos filmes da cineasta adquire mais autonomia e, não é, necessariamente, empregado para reafirmar o movimento das imagens. A partir da representação da experiência auditiva dos personagens, suas histórias adquirem novos sentidos e revelam uma marca estilística no uso da banda sonora. Com uma prática de experimentação de sons e a determinação de materiais sonoros destaca-se a importância do som para representação de diferentes formas discursivas sobre o tempo e sobre o esquecimento.

Em A Mulher Sem Cabeça, a ideia sobre o esquecimento ressurge como um processo auditivo invisível e interno quando a protagonista esquece uma significação externa para ouvir-se internamente. Constatamos que sons ambientes e fora do campo visual do espectador também podem representar uma experiência auditiva internalizada, subjetiva dos personagens, conferindo um clima misterioso à narrativa. Nos filmes analisados, ouvir a consciência também pode ser perceber a partir dos diferentes sentidos, ritmos e significados dos sons e das palavras. Neste sentido, o esquecimento de uma significação exterior disponibilizaria um estado de consciência para a escuta no qual os seres humanos podem penetrar mais na 
percepção tátil, textural do som. Ouvindo os sons dos mínimos detalhes do cotidiano dos personagens ou mesmo fortes estrondos acidentais, os ruídos exercem uma "função topológica, espacial e temporal", marcando os lugares e a época nos quais os personagens se encontram (CHION, 2011, p. 63).

Com o trecho analisado, pode-se constatar que alguns ruídos também exercem a função de criar uma emoção específica em relação ao acontecimento revelado pela imagem. A música de Nana Mouskouri e os ruídos ocos e secos do atrito do carro na estrada cheia de pedregulhos são usados para ressaltar um "efeito anempático", como referido por Michel Chion (2011). Descrevendo a influência do som sobre as percepções das imagens na linguagem audiovisual, Chion destaca que as músicas são constantemente usadas para exprimirem diretamente a sua participação nas cenas. As músicas conferem um ritmo, um tom e um fraseado às imagens, os quais foram adaptados a linguagem audiovisual em função dos códigos culturais, das emoções e dos movimentos representados pelos corpos dos personagens nos filmes. A música empática, nome que surge do termo empatia segundo o autor, se refere a uma música que representa a faculdade de partilhar o sentimento dos outros (CHION, 2011, p.14), ou seja, que reforça a imagem revelada pelos corpos dos personagens ou situações mostradas na tela através de um momento de suspensão da emoção, da contemplação. $\mathrm{Na}$ outra esfera, situa-se o efeito anempático:

o efeito anempático, na maioria dos casos, diz respeito à música, mas também pode ser usado com ruídos: por exemplo quando numa cena muito violenta ou após a morte de um personagem, um processo qualquer (ruído de máquina, barulho de um ventilador, jato de um duche, etc.) continua a desenrolar-se como se nada tivesse passado (CHION, 2011, p. 15).

Anempático trata-se do uso do som para reforçar a imagem através de uma indiferença 
ostensiva em relação à situação mostrada pela imagem, inserindo-a numa ordem estranhamente banal e frívola. Chion pontua que este tipo de relação de indiferença estabelecida entre a música e as imagens foram reconhecidas em certas óperas e usadas para representar um emoção mais forte que o habitual. Nestas óperas, certos tipos de regressão psicótica ou a paralisação das reações dos personagens eram representados. Em A Mulher Sem Cabeça, podemos constatar que o efeito anempático é utilizado com essa mesma função, reforçando uma sensação de paralisia através da não reação da personagem Verô à situação do acidente. Ironicamente após o acidente, continuamos a ouvir o som do motor do carro e a música alegre de Nana Mouskouri.

Ao suscitar diferentes possibilidades de sensações neste filme, o som seria o elemento capaz de delimitar o espaço mesmo sem sabermos exatamente o que há nele. Então, prestar atenção não seria somente iluminar os dados preexistentes na imagem, seria realizar o contraponto entre o som e a imagem a fim de delimitar uma presença acusmática no cinema, “em outros termos, não existe no cinema um campo sonoro autônomo, ele está em colaboração com a imagem ao criar suas dimensões reais e imaginárias, que ao mesmo tempo não deixam de ser transbordadas e transgredidas pelo som"31 (CHION, 2003, p. 222).

A classificação de um som é dada a partir da sua relação com a imagem, assim a definição de espaços e tempos na linguagem audiovisual habitam zonas entre as quais existem diversas gradações e lugares ambíguos. Ao conceber a escuta como entendimento, podemos constatar que o teórico Michel Chion toma o som como objeto de observação e o examina como elemento da representação cinematográfica vinculado à construção do espaço cênico. Ao aproximarmos fenomenologicamente das pesquisas de Michel Chion, destacamos o conceito de acusmática como base para a reflexão sobre a possibilidade de exemplificar

\footnotetext{
31 Tradução minha. CHION, Michel. Les trois frontières. In: Un art sonore, le cinèma: histoire, esthétique, poétique. Paris: Essais - Cahiers du Cinema, 2003, 221-225 p.
} 
diversas experiências de escuta presentes nos filmes de Lucrecia Martel.

Em $O$ Pântano e A Mulher Sem Cabeça, as histórias retratadas iniciam com duas mulheres, Mecha (O Pântano) e Verônica (A Mulher Sem Cabeça) vivendo a fatalidade de um acontecimento, acidente que detona uma crise cheia de lapsos, ausências e angústias sobre o esquecimento do seu passado. Há um paralelismo entre a situação dessas personagens: a decisão de esquecer o acontecido ao apagá-lo da memória, ocultando os fatos do seu entorno. Mecha deseja esquecer a vida caótica e decadente ao lado de um marido morimbundo e em uma fazenda onde nada acontece. Por sua vez, Verônica desiste de descer do carro após o acidente e ao tentar ser convencida pelo marido e amante de que nada grave se sucedeu, retoma os seus passos desde o acidente para descobrir que não há mais sinais desse acontecimento. Nesta contraposição, entre revelar e ocultar os sons, entre lembrar e esquecer as imagens, a polifonia audiovisual caminha, pouco a pouco, no sentido de gerar algum tipo de impacto no espectador. Neste caso, é o estranhamento que desperta a nossa atenção. A utilização do silêncio, as conversas em tons baixos e os sussurros entre os personagens revelam um ambiente externo repleto de informações sonoras subentendidas, ambíguas.

Acerca da ambigüidade, segundo Eduardo Seincman (2008), na cadeia comunicativa a experiência estética, qualquer que seja, envolve uma seqüência de lapidações de seu autor e intérprete-ouvinte que funcionam da seguinte maneira:

A cadeia comunicativa requer técnicas que consubstanciem, por um lado, os meios de expressar-se (sair de si, atuar de dentro pra fora, do interior para o exterior), os quais por sua vez, irão garantir as possibilidades de impressionar-se (voltar a si, sofrer a ação de fora pra dentro, do exterior ao interior). Expressar-se e impressionar-se retroalimentam-se continuamente: se o primeiro associa-se a memória de si, o segundo relaciona-se com o esquecimento de si (SEINCMAN, 2008, p. 36). 
É desse desdobramento do espectador cinematográfico, entre ouvintes e intérpretes da obra, que na comunicação audiovisual cria-se uma compreensão. Neste caso, ouvir e interpretar também poderia ser completar as lacunas com as informações sugeridas ou subentendidas pelo próprio filme. Esteticamente, não há impressões sonoras que não sejam acompanhadas das impressões visuais ou táteis, já que sentimos com todos os sentidos. Essas impressões são variáveis conforme as nossas condições culturais e sociais de ouvir. O recorte sonoro e o seu direcionamento no espaço não pode ser concebido como o olhar, se considerarmos a natureza omnidirecional do som e da escuta que se propaga em direção a todos os lados. Com efeito, são os gestos, as reações e as não reações dos personagens ou o direcionamento dos olhares que nos indicam a localização de um som. Aliados, nos filmes de Lucrecia Martel, os sons e a gestualidade dos corpos dos personagens conferem uma variação de ritmos e sentidos às imagens. E, mesmo que nenhum personagem reaja ao ouvir um som ruidoso ou ao escutar uma música para localizarmos a fonte do ruído, a forma como este som é apresentado também pode influenciar a percepção do espectador.

Nos dias atuais, diversas são as propostas de união dos sons e das imagens no cinema que foge de um padrão que repete antigos códigos naturalistas, segundo os quais temos a narrativa centralizada nos diálogos e no uso de músicas e ruídos como elementos redundantes em relação ao que a imagem já nos informa. Entretanto, cada vez mais, o espaço dado aos sons e aos ruídos cresce no cinema, sejam elas forças expressivas na construção de narrativas que provocam rupturas, a preservação ou a renovação de estilos. Os modos de construção da narrativa dos filmes escolhidos para realização desta pesquisa estão relacionados à quebra de uma ordem espaço-temporal linear, a criação de diversas temporalidades através do uso do som e que podem representar tanto espaços subjetivos (consciência e estados emocionais dos personagens), quanto espaços concretos (ambientes externos aos personagens). Estes sons transitam por um espaço de flutuação do discurso e entre os limites do campo e do fora de 
campo para produzir um impacto constante no espectador por não localizar na imagem os acontecimentos no momento mesmo em que eles se desenrolam. Os sons, as músicas e as vozes não afirmam o gesto do personagem, provocando uma perturbação no espectador que é impedido de embarcar na história pela trama ou por uma ordem espaço-temporal linear, reconduzindo-o ao tempo da experiência das sensações fílmicas. 
II -

A CASA DE LUCRECIA 


\section{Capítulo 3. "Es Siempre lo Mismo"}

O que pode ser mais insensato do que desejar fazer da linguagem a sede do imediato e o lugar de uma mediação, a captura da origem e o movimento da alienação ou da estranheza, a certeza daquilo que está apenas começando e a incerteza daquilo que sempre recomeça, a verdade absoluta daquilo que, no entanto, ainda não é verdadeiro? (BLANCHOT, O livro por vir, 2005, p. 67-68)

\subsection{Por uma poética dos sons cotidianos}

A segunda parte desta dissertação tem a finalidade de realçar figurações do corpo e modalidades do tempo nos filmes de Lucrecia Martel. No final da primeira parte desta dissertação, ressaltamos a presença de ruídos nas narrativas ficcionais de Lucrecia Martel que exercem as funções topológico-espaciais e outros que são usados para criar uma emoção específica em relação a acontecimentos revelados pela imagem. Sons que foram acusmatizados e repetidos se inserem na narrativa transitando entre as funções topológicas e 
espaciais (que conferem presença à imagem), para depois revelarem uma emoção, um pensamento ou uma sensação específica experimentada pelos personagens no seu cotidiano.

A partir de certas derivas de sentido, constatamos que o som surge nos longasmetragens de Lucrecia Martel como se introduzissem um elemento de vida, concreto, mínimo, o detalhe de uma contingência ou mesmo o excesso dela. Nos seus momentos de excesso, o som apareceu pela sua inabarcável e incontrolável presença, provocando certa perturbação nos espaços habitados pelos personagens através da perda da sua referencialidade causal, figurativa ou semântica. Estes sons, escutados na abertura de $O$ Pântano e de $A$ Mulher Sem Cabeça, imprimiram sua marca contínua nos acontecimentos acidentais. Com imagens dos momentos antes e depois, as imagens ausentes destes acidentes foram inscritas num tempo real através do uso de sons de trovões estrondosos, de taças estridentes ou de suaves silvos metálicos. Vimos que os mesmos sons que inseriram os acontecimentos numa irreversibilidade constituíram a representação de uma contingência marcada pelas ideias de esquecimento e de fadiga.

Conforme Mary Ann Doane (2012), a representação do tempo na linguagem cinematográfica também se dá a partir de acontecimentos que se implicam com aquilo que é fortuito, acidental, transitório e imprevisível. Em "La Emergencia del Tiempo Cinematico" (2012), o termo acontecimento aparece como um indicador dêitico do tempo, de algo que está se transformando (que está sucedendo) como a indicação de um lugar que ainda está desprovido de $\operatorname{sentido}^{32}$ (p. 210). Doane enfatiza que a representação de acontecimentos para

\footnotetext{
32 "Aunque el término acontecimiento implica lo fortuito, lo accidental, lo transitorio y lo imprevisible (como en la expresión los acontecimentos nos sobrepasan), también puede emplearse para denotar un alto grado de construcción, como en los conceptos de un suceso mediático o un evento social. El Oxford English Dicionary extrae la raíz etimológica del término event [ acontecimiento, evento, suceso] del latín eventus [acontecimiento, suceso] y del francés évenir [suceder, producirse]. El acontecimiento es un indicador deíctico del tiempo, un esto está sucediendo, esto está teniendo lugar. Como tal, es una mera indicación desprovista de significado. En el psicoanálisis freudiano, el trauma es consecuencia de la falta de asimilación de un acontecimento que tiene repercusiones psíquicas años después." Ver: DOANE, Mary Ann. "El tiempo muerto o el concepto de acontecimiento". In: La Emergencia del tiempo cinematico: la modernidad, la contingencia y el archivo. Murcia: Cendeac, 2012, p. 209.
} 
a psicanálise, mesmo aparentemente desprovidos de sentido, produzem sintomas que atravessam os anos e deixam marcas psíquicas e corporais no sujeito.

Desse modo, apontamos nossas reflexões para dentro do contexto de encenações mínimas e da representação de diversas temporalidades e espaços subjetivos nos filmes de Lucrecia Martel discutidas através dos estudos de Denílson Lopes (2012), Mary Ann Doane (2012) e Ana Amado (2007). Através dessa aproximação, destacamos uma reflexão sobre as relações entre o uso dos ruídos do cotidiano dos personagens e a produção de uma banda sonora que nos faz repensar um espaço estético da contemplação do som no cinema. Nos filmes de Lucrecia Martel, a representação da experiência de escuta dos personagens revela um estranhamento de ouvir a si mesmo ou provoca sustos ao ouvir os sinais do mundo. Enceguecidos, uma interiorização da escuta dos personagens acontece no decorrer da narrativa através de alterações de sentidos do mesmo som que transitará entre a concretude do espaço físico e geográfico para representar alguma angústia, medo ou crise imaginada pelos personagens. O medo de ouvir os sons do mundo ou os próprios sons internos, seus pensamentos e desejos, interditam a visão dos personagens.

Nestes filmes, o acesso ao olhar e ao desejo será sempre impedido por algum som que perpassa a narrativa, interrompendo falas e provocando acidentes mortais. Estes sons tem sua entrada anunciada nas cenas para provocarem uma perturbação, pois possuem o poder de destruir aquilo que se deseja ver ou possuir. A relação estabelecida entre som e imagem nos filmes de Martel nos impede de termos certeza sobre a veracidade dos acontecimentos insinuados.

Outro elemento que contribui para construção deste espaço de incertezas e insinuações, a imagem revelada pelo enquadramento axial (que corta a cabeça e as pernas) mostra apenas o tronco dos personagens. Este tipo de enquadramento aparece em $O$ Pântano e em A Menina Santa, pouquíssimas vezes, porém surgem nos momentos decisivos, aumentando o enigma em 
relação aos eventos anunciados. Enfatizando o jogo entre olhar e escutar, a cineasta escolhe os momentos antes ou depois dos acontecimentos acidentais para usar esse enquadramento. Logo no início d'O Pântano, as imagens dos troncos de corpos feios, sudorosos e bêbados se mantêm como um eco na lembrança dos personagens e espectadores para ser reavivada no último plano do filme. Em A Menina Santa, o enquadramento axial nos é apresentado nos primeiros instantes do filme através do olhar de Dr. Jano para o corpo de Helena, que está com a cabeça atrás de uma janela. Juntos ao médico, espiamos apenas as costas de Helena recortada pelo decote sensual do seu vestido. No último filme da cineasta, A Mulher Sem Cabeça, o enquadramento axial permanece e ganha força aparecendo em quase todas as cenas onde Verô é mostrada. O mesmo enquadramento aparece, diversas vezes, em todos os filmes da cineasta também para ocultar a boca dos personagens que falam ou para ocultar um acontecimento dado somente pela escuta do seu som e que manterá o suspense sobre a sua forma física até os últimos momentos dos filmes.

Sob a ótica desta perspectiva, os filmes de Lucrecia Martel reafirmariam uma linhagem na qual pensar sobre os movimentos, deslocamentos e trajetórias dos personagens é pensar também sobre "um cotidiano global" (LOPES, 2007, p. 15). Não somente a partir dos estudos de fluxos migratórios e diásporas, mas através de um "espaço da ação que se dissolve de tal maneira em favor de um acontecimento de metamorfoses contínuas, o espaço da ação é como uma paisagem continuamente modificada por variações de luz, por objetos e formas que surgem e desaparecem” (LEHMANN apud LOPES, 2012, p. 122).

Trata-se de uma perspectiva que Denílson Lopes aponta nos seus últimos livros, "No coração do mundo" (2012), "Cinema, Globalização e Interculturalidade" (2010) e "A Delicadeza: estética, experiências e paisagens" (2007), livros nos quais o local, o comum e o mínimo aparecem pensados como possibilidades na busca de uma encenação minimalista em pequenas localidades. Nos filmes analisados por Denílson Lopes, destacam-se elementos de 
uma encenação onde "há uma perseverança no concreto, nas estórias mínimas sem melodrama, dissolvidas em várias cenas e subenredos que não se resolvem de todo, de personagens que se friccionam e se esbarram" (idem, ibidem, p.157). Segundo o autor (2012), O Pântano apresentaria alguns elementos dessa encenação em busca do comum: sua narração segue os personagens a partir de atos banais destinados a não se realizarem, como a viagem à Bolívia, uma queda à beira da piscina ou a morte de um boi. Acontecimentos interrompidos que se encontram atravessados por uma encenação onde a natureza é apresentada como uma ruína hostil (AGUILAR apud LOPES, 2012, p.157), acidental. Nestes filmes, uma dramaturgia desdramatizada encarnaria corpos marcados por feridas e impedimentos, construindo uma narrativa ficcional onde os atos banais e acidentais são incorporados pelas “lógicas do azar" (AGUILAR, 2010) e parecem mover os personagens em direção à morte.

A incorporação de uma lógica do azar pode ser apontada também em relação ao uso dos sons, que inseridos nas narrativas através de lendas sobre ratas-africanas ( $O$ Pântano) e fantasmas de mulheres mortas (A Menina Santa, A Mulher Sem Cabeça) criam leves sustos e estremecimentos nos personagens e espectadores. Em $O$ Pântano, um som de um latido do cachorro adquire sentidos assustadores para a criança Luchi, criando uma confusão em relação ao sentido de um som que é habitualmente familiar e torna-se excessivamente estranho, selvagem e ameaçador.

Em A Menina Santa, temos o som estranho e inabitual da presença de um theremin. O instrumento no qual se toca sem encostar as mãos nas cordas, torna-se objeto de fascinação dos personagens e adquire o sentido de uma dúvida espiritual com a descoberta do desejo pela personagem Amália. Durante a audição deste instrumento, a adolescente é levemente molestada e não reage ao fato. O mesmo evento repete-se por mais uma vez e a personagem começa a perseguir o médico molestador (Dr. Jano) sofrendo a confusão entre os sinais de uma vocação para salvar um homem e as tentações do demônio. Ao longo do filme, vários 
outros ruídos diegéticos surgem inseridos do cotidiano dos personagens para serem apresentados, posteriormente, adquirindo contornos assombrosos.

A perseguição do homem pela adolescente, que se esconde atrás das frestas de portas e alambrados às voltas de uma piscina, acontece recheada por estes sinais sonoros que revelam uma presença espiritual, fantasmagórica. Estrondos ouvidos causam sustos nas adolescentes para depois serem reveladas as imagens bizarras e banais da sua fonte sonora causal - um homem nu cai de um apartamento vizinho; o som de tiros que parecem significar uma perseguição diabólica para a adolescente José, mas são apenas fruto de uma caçada de animais; o som de um ônibus atravessando uma ponte que adquire contornos assombrosos depois que ouvimos a história de uma mulher morta sobre aquela ponte.

A história popular, contada por uma das adolescentes amigas de Amália, nos fala sobre um acontecimento, um acidente de carro. Uma mulher aparece para um caminhoneiro na beira da estrada e pede ajuda para salvar um bebê. A mulher disse que viu o acidente, um carro caiu numa vala perto da ponte e um casal estava morto, mas que ainda havia um bebê vivo. Misteriosamente a mulher some. $\mathrm{O}$ homem desce na vala onde teria acontecido o acidente e descobre que havia mesmo um bebê vivo, mas que a mulher que estava morta era a mesma que pediu ajuda na estrada. A história, contada dentro de um ônibus em movimento, termina com a garota apontando para a ponte onde aconteceu o acidente. O som do atrito do pneu numa massa de asfalto mais grossa, faz com que o espaço interno do ônibus seja invadido pelo som grave e denso do atrito conferindo materialidade à cena.

Uma concretude física altera as sensações auditivas das personagens, chamando atenção para a ponte e a história narrada, que acaba adquirindo contornos assombrosos quando sobreposta à lenda que fala da morte. Também nos detemos, no final capítulo anterior, sobre um som mínimo, silvo metálico e agudo, que parece marcar a temporalidade das cenas através da sensação de uma dúvida sobre a morte em A Mulher Sem Cabeça. 
No conjunto das obras analisadas, podemos encontrar uma enunciação que abre espaço nos seus momentos mais sublimes para se separar dos seus enunciados. Uma separação próxima e semelhante às comentadas por Michel de Certeau (1998), quando destaca que ocorre nas vozes operísticas uma perturbação como pequenos estremecimentos nas sintaxes das palavras que revelam lugares do corpo que antes estavam ocultos, por não terem mais capacidade de falar. Certeau cita também os "filmes de vozes" de Marguerite Duras que, assim como as óperas, são consideradas obras reveladoras dos "ruídos dos corpos dos personagens" (CERTEAU, 1998, p. 256), gritos que escapam. Usando o exemplo dos filmes desta cineasta e escritora francesa, Certeau (1998) nos fala sobre figuras ficcionais modernas que traspassam o discurso para ouvir vozes que estão ligadas pelo desejo, "Vozes de mulheres... vêm do espaço noturno, como que elevado de um balcão acima do vácuo, do todo. Rasgam-se. Ignoram-nos. Não podem ser ouvidas" (CERTEAU, 1998, p.256).

Para o autor (2008), a partir do retorno dessas vozes é que um corpo social fala em citações, em pequenos fragmentos de relatos e através de tonalidades das palavras que estão ligados como resíduos de enunciados. Dentre as diversas maneiras de aparição dos ruídos de corpos apontadas pelo autor, destacam-se a incorporação de algumas formas de oralidades nas narrativas ficcionais como as cantigas de rodas, as rimas e os escrínios sonoros de sentidos perdidos, que revisitam as lendas e os fantasmas que continuam povoando a vida cotidiana" (idem, ibidem, p. 259).

Uma discussão sobre a incorporação de formas de oralidade nas narrativas ficcionais fomenta outro debate que se estende a outras formas da linguagem que não a literatura. Neste sentido, pretendemos apontar uma relação entre o processo de incorporação de uma duplapertença do som nas narrativas e a identificação de algumas citações, lendas ou escrínios sonoros que surgem na linguagem inquietas; perturbações que são capazes de alterar a organização espaço-temporal nestes filmes. Operando sob este domínio, tais escrínios sonoros 
e lendas apareceriam como um comentário ou análise para produção de histórias a partir de vestígios e rastros sonoros retirados de uma tradição oral (idem, ibidem, p. 250). Neste sentido, a identificação de formas de oralidade nos interessa para apontar nas películas de Martel como através do uso de lendas sobre ratas-africanas e fantasmas de mulheres mortas se estabelece um ponto de mudança na narração, certo tipo de impressão sonora que aparece na narrativa ficcional para "demarcação de uma instabilidade" (CERTEAU, 2008, p.247). A inserção destes escrínios sonoros a partir de uma lógica ambígua constrói uma experiência espacial no ponto de uma passagem, espaço de eminência e desaparição “onde há um risco de se perder a qualquer instante" (LOPES, 2012, p.185).

\subsection{O Nuevo cine argentino e suas figuras ficcionais contemporâneas}

Para o crítico de cinema argentino Gonzalo Aguilar, assim como uma nova geração de jovens cineastas, Lucrecia Martel se concentrou em produzir narrativas ficcionais que mostrassem olhares enviesados sobre as ruínas da sociedade argentina, "ao contrário de ressaltar elementos alegóricos, constituem histórias que se desenvolvem em torno de desencontros e perdas" ${ }^{, 33}$ (AGUILAR, 2010, p.48). A precariedade das relações sociais e o desfacelamento dos núcleos familiares tradicionais se encontrariam presentes nos filmes através de eventos acidentais e ruínas que antecedem as histórias. Em "Otros Mundos: un ensayo sobre el nuevo cine argentino" (2010), Gonzalo Aguilar reconhece duas tendências nos

\footnotetext{
33 Tradução minha. "Las ruinas aparecen en el film mostradas al sesgo y, antes que elementos de una alegoría, constituyen el ámbito en el que desarolla una historia de pérdidas y desencuentros. No son ruinas de una antiguedad prestigiosa ni del lejano siglo XIX, son - como las estaciones del servicio - ruinas de la moderninad. [...] Mediante el accidente y la ruina, estas historias se abren al presente y al reconocimiento de que ya no hay narración previa que señale los caminos a seguir. El accident o las ruinas están antes de que la historia comience y eso hace que todas las conexiones sean débiles". Ver: AGUILLAR, Gonzalo. Otros Mundos: un ensayo sobre el nuevo cine argentino. Buenos Aires: Santiago Arcos Editor, 2 edição atualizada, 2010, p. 48.
} 
modos de produção no Nuevo Cine Argentino. Aguilar (2010), baseado nos mecanismos da dispersão e da permanência, do nomadismo e do sedentarismo, nos apresenta uma análise sobre os filmes do nuevo cine argentino. Neste recorte, o autor procura analisar os filmes nos quais os impactos surgem de um fora mais absoluto, através de acidentes que se anunciam a todo o momento, mas nunca se sucedem nas narrativas ou dão-se no espaço fora-de-campo. Para Aguilar (2010), no cinema argentino as recentes figuras da ficção não mais produzem um sentido de pertencimento a partir da permanência de uma ordem capitalista ou da eficácia dos laços de associação tradicionais e modernos da família. Com uma análise centrada em cineastas específicos como Lisandro Alonso, Pablo Trapero, Martin Adjemián, Adrián Caetano e Lucrecia Martel, Aguilar estabelece uma divisão em relação ao tipo de movimentos dos personagens e temas retratados na filmografia argentina nas duas últimas décadas.

Conforme Aguilar (2010), na linha de um mundo do desejo nômade predomina as narrativas ficcionais orientadas pelo constante deslocamento dos personagens de classe média que já não tem um lugar fixo de moradia ou sentem o vazio de transitar por vários espaços onde nenhum se converte em ponto de retorno. Como exemplo, pode-se constatar nos filmes Pizza, birra, faso, de Adrián Caetano, Mundo Grúa, de Pablo Trapero e La Liberdad, de Lisandro Alonso a revelação de "um estado contemporâneo de permanentes movimentos, translações, situações de não pertencimento e a dissolução de qualquer instância da

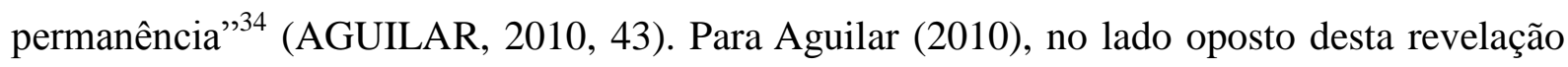
localizado na linha da decomposição de instituições sedentárias, encontram-se os filmes da cineasta Lucrecia Martel que estariam marcados por uma experiência precária centrada nas situações claustrofóbicas de decomposição do núcleo familiar. Nas películas de Lucrecia Martel, a presença de uma paisagem em ruínas pode ser detectada através da eclosão de

\footnotetext{
${ }^{34}$ Tradução minha. "Es decir, no entendemos el nomadismo como una evasión romántica hacia el precapitalismo o una línea de fuga según lo propone Gilles Deleuze, sino más bien como un estado contemporáneo de permanentes movimientos, translaciones, situaciones de no pertenencia y dissolución de qualquer instancia de permanencia". (AGUlLAR, 2010, p.43).
} 
acidentes e corpos descompassados que surgem sem nenhuma explicação prévia.

Aguilar (2010) nos conduz para enfrentar o embate ético e estético de refletir sobre os espaços e as narrativas da intimidade ao destacar uma poética do cotidiano como instrumento de análise de um cinema contemporâneo marcado pela globalização. Um cinema que se afasta do conceito de cultura nacional para destruir as fronteiras com a produção de filmes nos quais habitam personagens comuns e desprovidos de referenciais temporais, espaciais ou reflexivos. Filmes que se concentram em representar os afetos e as emoções dos personagens errantes ou demasiadamente fincados num lugar que já se desfez em ruínas há muito tempo. Nestes filmes, pode-se dizer que a contenção dos afetos e a rarefação dos espaços são exploradas através da materialidade dos elementos cinematográficos - a luz, o som, a cor, os enquadramentos e ângulos de imagem destacam-se enfatizando certo formalismo através da redução dos signos por meio da sua repetição e da sua duração (AGUILAR, 2010; LOPES, 2007; LEHMANN, 2007).

Conforme Aguilar (2010), o uso do som nas películas de alguns cineastas, que surgiram no contexto do Nuevo Cine Argentino, não se encontra tão estratificados e, em muitos casos, pode-se constatar que a textura sonora teve tanta importância quanto à compreensão do significado das palavras (p. 45). Para o autor (2010), em Los Muertos (Lisandro Alonso, 2004), Los Guantes Mágicos (Martín Rejtman, 2003), Sábado (Juan Villegas, 2001), Pizza, Bira e Faso (Adrián Caetano e Bruno Stagnaro, 1997), Nadar Solo (Ezequiel Acuña, 2004) e nos filmes de Lucrecia Martel existe "uma massa sonora na qual o indiscernível está em constante tensão com a diferenciação. Assim, muitas vezes, os diálogos são tratados como bandas sonoras"35(idem, ibidem. p. 95).

\footnotetext{
35 Tradução minha. "El sonido em las películas del nuevo cine argentino no están tan estratificado (música, diálogo, sonidos ambientales) sino que se genera uma verdadera red, una masa sonora en la que lo indiscernible está en tension con la diferenciación. Así, por ejemplo, los diálogos son tratados como bandas de sonidos y muchas vezes su textura sonora tiene tanta o más importancia que la comprensión del significado das palabras." (idem, ibidem, p. 95)
} 
Um dos primeiros filmes dessa nova geração de cineastas, $O$ Pântano se concentra no tema da degradação do espaço de convivência familiar. Nas duas casas retratadas neste filme, temos exposta a indefinição dos vínculos de parentesco entre duas famílias do noroeste argentino. A incorporação do acidental se apresenta no uso de sons diegéticos advindos do espaço fora de campo que aparecem na cena como brusca irrupção sonora. Trata-se para o autor de ressaltar a ênfase dada pelo uso do som como um elemento de textura expressiva que impulsiona o espectador à percepção das sensações corporais e afetivas dos personagens e que, em sua maioria das vezes, não cabem ser nomeadas através da fala e nem descritas previamente nos roteiros.

Neste sentido, pode-se constatar que nos três longas-metragens de Lucrecia Martel, o som aparece filtrado pela subjetividade dos ouvidos dos personagens em cena e as divisões espaciais - se in, off ou fora de campo - utilizadas entre som direto, diálogos, ruídos e música não se apresentam tão discerníveis. Nestes filmes, a assimilação de sons do cotidiano dos personagens gera sustos, suspensões, saltos, interrupções e leves estremecimentos na ordem espaço-temporal, ressaltando as diversas potencialidades expressivas e narrativas do som. Tradicionalmente no cinema, os diálogos provocam uma atitude de escuta semântica no espectador que para interpretar a trama dos personagens selecionam aquilo que é importante ouvir em detrimento de um sentido. Caminhando paralelamente, outras atitudes de escutas são ativadas para que possamos compreender as narrativas ficcionais.

No cinema, segundo Chion (2011), ao ouvir sons que surgem da instância diegética dos personagens, os espectadores acionam uma escuta causal quando identificam a fonte sonora em relação ao seu objeto causal ou mesmo quando seguem um som a partir de uma mudança de pressão, de velocidade e de amplitude podem seguir a sua história causal (idem, ibidem, p. 28). Outra atitude de escuta específica que podemos encontrar na fruição cinematográfica, a escuta reduzida implica na fixação dos sons em um suporte que possa ser 
analisado. Acessada pelos técnicos, cineastas e críticos, a repetição da escuta de um mesmo som afastaria num primeiro momento as relações figurativas, causais e semânticas para promover uma escuta que esteja atenta às qualidades específicas de timbre e de textura (idem, ibidem, 29-31). Neste sentido, quando se identifica os intervalos entre dois sons ou percebemse as qualidades perceptivas entre o agudo estridente de uma taça e a densidade grave de um estrondo estamos utilizando uma escuta reduzida para isolar as qualidades sonoras. Pretendemos apontar a seguir, como nos filmes de Martel uma massa indiscernível sonora é criada através do deslizamento das funções do som nas narrativas, o que provoca uma constante tensão entre uma escuta atenta as qualidades sonoras - a qual poderia nomear como “escuta textural"- e uma escuta semântica.

A "escuta textural" é usada como termo pelo músico e pesquisador Silvio Ferraz no livro "Música e Repetição: a diferença na composição contemporânea". Para o autor, este tipo de escuta está relacionado a um modo de síntese do tempo. Neste livro, Silvio Ferraz estabelece uma relação entre a saturação de um determinado espaço sonoro que tornam uma densidade alta e guia o ouvinte para uma escuta textural.

\begin{abstract}
A escuta textural se dá no terreno da mônada indivisível, suas dobras são infindáveis e sua totalidade inabarcável, de certo modo estamos entre a constatação e a não constatação do som. Estamos entre os "espaços surdos" - o do som do carro que não era percebido - e as dobras irrepetíveis do som, sendo que a cada nova escuta se destacam diferentes dobras. (FERRAZ, 1998, p.165).
\end{abstract}

Trata-se de apontarmos aqui um tipo de escuta que foi priorizada nas obras de músicos minimalistas onde a diferenciação dos sons não se dá através do excesso dos sons, como apontado por Ferraz, mas, ao contrário, quando a saturação dá-se pela ausência. Nas obras musicais minimalistas, a escuta textural desenrola-se percorrendo um só espaço através de uma repetição extensiva - com a sucessão de eventos iguais - e de uma repetição intensiva 
- na qual a repetição do mesmo evento sonoro revela-se totalmente diferente a cada instante.

Anteriormente, apontamos uma aproximação da estética minimalista através da priorização de encenações que usam a repetição, a duração e o silêncio como elementos que revelam os momentos de uma plenitude sensível do cotidiano, lugar onde a enunciação separa-se dos seus enunciados. Para estabelecer melhor esta relação estrutural entre o silêncio e a repetição na estética minimalista, saímos do território da linguagem cinematográfica e musical para recorrermos a um conceito da teoria da comunicação social.

Para a teoria da comunicação, a redundância é a reiteração daquilo que foi expresso em qualquer linguagem, seja ela visual, gestual ou sonora, a fim de garantir a transmissão de uma mensagem ${ }^{36}$. No livro, "Os Cantos da Voz: entre o ruído e o silêncio" (1999, p.86), a musicóloga Heloísa Valente relaciona essa acepção do conceito de redundância com o uso do silêncio pela música de estética minimalista. Segundo Valente (1999), um aumento da redundância significa, para a comunicação visual, um aumento da previsibilidade, porém o uso abusivo desta prática resultaria numa não transmissão das informações, "pois a mensagem não conterá nenhum elemento novo a ser percebido pelo receptor" (p.87). Na música contemporânea de vanguarda, a repetição redundante dos elementos estruturais é utilizada como um recurso expressivo pela música minimalista. Os compositores minimalistas se servem de "variações rítmicas discretas", mas fundadas numa "pulsação pregnante" (idem, ibidem, p. 87) e de imersão nos ritmos sonoros que marca o tempo e fixa um acompanhamento sensorial/corporal. Neste tipo de espaço minimalista, os processos sonoros são revelados pelos compositores para privilegiar o microcosmo, o detalhamento e "parecem se realimentar não da intervenção do artista, mas da sua própria lógica autônoma até atingirem a entropia"37, ou um estado aparente de desordem.

\footnotetext{
${ }^{36}$ C.f. KOELlREUTTER, J.J. 1990, p. 119. "Terminologia de uma nova estética da música", Porto Alegre: Movimento.

${ }^{37}$ Cf. Wisnik, José Miguel, ver p. 88. “Os Cantos da Voz: entre o ruído e o silêncio”. A entropia é um conceito da
} 
A acepção do silêncio, neste caso, pode agir como um ruído de código, um elemento expressivo de delineamento, de simplicidade ou ainda enfatizar uma sensação de monotonia. Para a história da música contemporânea, a obra 4`33” de John Cage foi um grande marco da utilização do silêncio como elemento expressivo e que "tinha o intuito de despertar os nossos ouvidos para os sons ambientes"38. Nos longas-metragens de Lucrecia Martel, um alto índice de reverberação e o silêncio são usados para ressaltar uma sensação de uma escuta íntima, corporal e táctil.

Sob esta dualidade, procuramos nos filmes desta cineasta eventos sonoros que possam revelar, através da sua repetição, diferentes sons a cada instante, intensificando o debate em torno do esvaziamento de sentidos e do aumento das experimentações sensoriais. Assim, num primeiro momento nos atemos a apontamentos sobre o uso e a repetição dos sons nos filmes, para num segundo momento apontarmos uma repetição gestual e corporal dos personagens que reforçam a ideia de uma fadiga, cansaço, esquecimento ou saturação aparente do espaço fílmico.

física, referente aos estudos de Einstein sobre a perda de uma energia, ou ainda o equivalente a uma desordem. Segundo Wisnik, Heloísa Valente e outros teóricos como Murray Schafer, a música contemporânea de vanguarda teria sido fortemente influenciada pelas leis de entropia, sendo um dos conceitos difundidos com o uso dos sons ruidosos na música. Para a teoria da comunicação a entropia "mede aquela parte da mensagem perdida, no processo de passagem do emissor para o receptor. A mensagem transmitida deveria produzir um certo comportamento que, no entanto, não se verifica" (VALENTE Apud TEIXEIRA COELHO, 1980: 132) A entropia e a simetria foram ainda conceitos importantes para o estruturalismo de Lévi-Strauss. Segundo o antropólogo Mário de Almeida, "no estilo lévi-straussiano os tropos matemáticos e físicos tem um peso forte. Expressam idéias básicas sobre a sociedade humana, e para Lévi-Strauss é mesmo essencial que essas metáforas venham da física e da matemática, já que entre essas idéias está a de que a ordem humana se prolonga na ordem da natureza. Há duas metáforas básicas: uma, baseada na idéia de grupo de transformações, e cuja essência é a existência de simetria; outra, baseada na idéia de máquina, e cuja essência é a noção de irreversibilidade. A primeira relacionase com o olhar distante: no limite, um olhar que não se situa em nenhum lugar. A segunda relaciona-se com os tristes trópicos: com a passagem do tempo e com a irrupção inevitável da desordem" . Ver "Simetria e Entropia: sobre a noção de estrutura de Lévi-Strauss", Revista de Antropologia, v.42, n.1-2, São Paulo,1999.Não pretendemos aqui utilizar estes dois termos apontados dentro da obra de Lévi-Strauss, mas apontar como as derivações que esse tipo de pensamento estrutural levi-straussiano foi importante para a teoria musical do século XX. Ver também, "A cidade polifônica: ensaio sobre a antropologia da comunicação urbana", de Massimo Canevacci, 1993

${ }^{38}$ C.f. Schafer, Murray. “A Afinação do Mundo”, 2001. 


\subsection{Sons fora de campo: elementos de perturbação na mise-en-scène}

Neste ponto, faz-se necessário a retomada da análise a partir do viés de uma estruturação imagética presente nos filmes de Lucrecia Martel. A experiência da representação do som e da escuta nos abre espaço para outras imagens, afetos e pulsões que se destacam na encenação desses filmes.

Às voltas da questão “terá a encenação morrido?", Jacques Aumont constata na abertura do livro "O Cinema e a Encenação" que a encenação no cinema contemporâneo mesmo com filmes que se situam distantes de uma concepção da arte do plano (ou da planificação) - “permanece e, permanecerá, na raiz de toda arte cinematográfica imaginável, pelo menos enquanto o cinema consistir em filmar corpos humanos a exprimirem-se, a representarem, a sentirem, a viverem num quadro, num meio, num espaço e num tempo" (AUMONT, 2011, p.13). No seio desta perspectiva, Aumont (2011) destaca que as palavras encenação (mise-en-scène) e encenador (metteur-en-scène) foram retiradas "quase à força" de uma herança teatral, onde o texto e o lugar estabeleciam as regras de uma técnica, de um fazer.

Desde os seus primórdios, o verbo elegido como lugar central e a noção de espaço trouxeram para a linguagem cinematográfica uma série de questões e problemas que ainda não foram solucionados. O diálogo era base de uma organização de entradas e saídas dos atores em cena. Segundo Aumont, "a representação teatral nesta concepção do século XIX, que ainda perdura e alimenta a televisão, é feita apenas para ouvir um texto, para o ouvir dizer e para o ouvir dito" (idem, ibidem, p. 25). O autor aponta que, ao longo do século XX, a linguagem cinematográfica e seus "encenadores" empreenderam inúmeras tentativas de fuga desse fantasma verborrágico na busca de aproximar-se de uma capacidade expressiva (não verbal) do corpo. Já no cinema mudo, a busca por uma representação que estabelecesse uma 
correspondência entre gestos e estados sensoriais e afetivos se manifestava nas bases de uma gestualidade excessivamente expressiva e na mímica do ator.

Entretanto, paradoxalmente a convenção de gestos artificiais e impostados, também brotava nos filmes deste primeiro período gestos naturais e espontaneamente copiados em busca daquilo que Mary Ann Doane (2002) denominou como imagens marcadas pela captação do tempo ou momentos de "aparente plenitude" do cotidiano. Pequeninos gestos, figuras que atravessam o meio do quadro com seus corpos contorcidos: o singelo sorriso de uma atriz; um olhar que se perde em soslaio para acompanhar o movimento frenético de um garçom (Partie d'Écarte, 1896); folhas de árvores que se mexem no fundo do quadro atravessando a imagem em primeiro plano dos pais dando comida a um bebê (Repás de Bébé, 1895) (DOANE, 2002, p. 177).

Uma corporalidade descontrolada e espontânea, o tempo de um instante-qualquer que se apresentava num "cinema dos primórdios" deu passagem ao cinema sonoro que teria marcado outro momento da encenação na linguagem cinematográfica. Momento apontado por Michel Chion (2011) e Jacques Aumont (2011) como "regressão a um estado primitivo da encenação" no qual a imagem da câmera foi aprisionada numa imobilidade e a montagem perdeu sua fluidez (AUMONT, 2011, p. 28), além de o som ter sido reduzido a sincronicidade de uma fala à imagem (CHION, 2011, 13-14). Com a escuta e o olhar enclausurados era o verbo quem dominava a cena. Segundo os autores, a noção de espaço cinematográfico estaria atrelada a movimentação dos corpos dentro do quadro, naquilo que estava visível e que era verbalizado para o espectador. Essa questão empreendida por Aumont, Chion e por muitos outros críticos, cineastas e teóricos demonstrava certa crença de que na linguagem cinematográfica seria "a liberdade do ponto de vista, somada aos elementos que constituem sua especificidade técnica, [que] afastaria o cinema, em tese, do teatro" (OLIVEIRA JR., 2010, p.5). 
No contexto de um processo evolutivo da linguagem cinematográfica, relembramos um momento específico destacado na dissertação "Mise-en-scène e Cinema de Fluxo", de Oliveira Jr. (2010) que traz à tona uma discussão empreendida sobre a noção de espaço e cena a partir de um artigo escrito pelo cineasta Eric Rommer. Em "Le cinéma, art de l'espace" (1954), Rommer apontou uma definição do espaço cinematográfico que inseria os elementos de transição de um cinema clássico para um cinema moderno:

O espaço cinematográfico se definiu assim em relação ao da cena à um só tempo pelo estreitamento da superfície de visibilidade e pela extensão do lugar da ação; não é, portanto, só o interior de cada um dos planos que o realizador deve determinar em função de uma certa concepção da espacialidade, mas a totalidade do espaço filmado ${ }^{39}$. (ROMMER apud OLIVEIRA JR., 2010, p. 28)

Como bem apontado por Oliveira Jr. (2010), numa comparação entre cena e espaço cinematográfico delimitou-se uma possibilidade de compensação do espaço bidimensional da tela com o extravasamento do conteúdo visual do plano para um espaço invisível. O lugar da ação estendeu-se para as bordas do quadro, provocando um prolongamento virtual da cena “que inclui não apenas o fora-de-campo concreto (aquela porção de espaço contígua ao plano, ainda que não apreendida pelo campo da visão) como também toda ideia de espaço criada pela diegese" (OLIVEIRA JR., 2010, p.28-29). A polêmica empreendida por Rommer e ressaltada por Oliveira Jr. é a de que no cinema moderno os procedimentos espaciais "se tornam menos aparentes" (idem, ibidem, p. 29), no sentido de uma economia dos meios expressivos e da plasticidade da imagem. Distante de uma posição polêmica, gostaria de ressaltar aqui tal momento de transição, no qual a encenação passa a ser considerada a partir da potência de uma invisibilidade.

\footnotetext{
${ }^{39} \mathrm{O}$ artigo de Eric Rommer foi originalmente publicado na revista La Revue du Cinéma, n. 14, junho de 1948.
} 
Em "Práxis do Cinema”, livro publicado originalmente em 1969, Noel Burch se refere ao espaço fora-de-campo como um elemento de perturbação que seria, antes de tudo, "o habitat natural do "acaso" no cinema, lugar onde existe a ameaça inerente a tudo que é invisível e fora de controle" (BURCH, 1992, p. 136). No início do capítulo sobre "O uso estrutural do som", o teórico também aponta um princípio de economia dos meios que estaria presente nos filmes de cineastas deste período, como Robert Bresson (Mouchette, Le diable probablement, L'argent...) e Gregory Markopoulos (A Twice Man, 1963) que substituíam imagens por sons.

Das diversas relações dialéticas entre espaço visual e presença sonora, Burch destaca a possibilidade do som off $^{40}$ precisamente poder substituir a imagem a partir de um grau de legibilidade variável: "um grande plano sonoro de uma gota que cai numa banca de cozinha poderá ser tão difícil de reconhecer pelo ouvido enquanto tal, como a imagem em plano de pormenor da articulação do polegar de uma mulher (idem, ibidem, p. 112). O exemplo servenos para aproximarmos das imagens evocadas pelos sons nos filmes de Lucrecia Martel. As qualidades evocativas dos sons nas películas desta cineasta, por muitas vezes, estão ligadas aos poderes evocativos do espaço fora-de-campo e de todo o imaginário que se relaciona com ele: também os olhares dos personagens direcionados ao espaço fora-de-campo trazem uma indecifrabilidade para a imagem que é lançada além daquilo que está visível.

Nos filmes de Lucrecia Martel, a experiência de significação dos seus filmes, ou seja, de deslocar-se para um universo ficcional cinematográfico nos quais os personagens, por muitas vezes, ocupam planos opostos à experiência daqueles que veem e escutam, aborda os

\footnotetext{
${ }^{40}$ Em "Práxis do Cinema" Burch utiliza a terminologia som off para designar um som que está fora do espaço da visualidade do espectador. Ao longo desta dissertação adotamos a terminologia referencial de Michel Chion, que separa entre som off (fora da diegese e não visualizado), som in (pertencente à diegese e visualizado) e som forade-campo (não visualizado, mas pertencente à diegese). Além desta separação, Chion ainda promove a separação entre sons internos objetivos (fisiológicos - sons de batidas do coração, rumores da respiração, etc...), sons subjetivos (do pensamento, monólogo interior) e sons territoriais (sons do cenário que são usados como ambiência, sem apresentar necessariamente uso narrativo). Ver: CHION, Michel. Audiovisão, 2011.
} 
pensamentos e os corpos dos personagens que em um sentido mais amplo, são incorporados à uma estrutura simbólica para serem viabilizadas na sociedade. Distante dos domínios da visualidade, os elementos melódicos e rítmicos das vozes dos personagens - como os rumores, os sussurros, a respiração - e a gestualidade possibilita à construção fílmica o estabelecimento de estratégias discursivas e sensoriais cada vez mais presentes na arte contemporânea. A partir da utilização das potencialidades do som e do silêncio, trata-se de propor uma interrogação sobre as práticas que promovem explorações de um espaço subjetivo no nível da vida psíquica dos personagens através da repetição de fragmentos sonoros que emergem do silêncio.

Nos filmes de Martel, a corporalidade e o desejo estariam presentes em um interesse pelo feminino, onde a visualidade encontra-se às voltas de um sentir, dos afetos e sensações corporais dos personagens, considerando outros dispositivos de sentido como a escuta e a tatilidade. Por sua vez, o espectador vê-se preso dentro de um jogo onde se pode escutar, mas não vê o que se escuta. Neste jogo entre ver e ouvir, os espectadores encontram-se próximos das sensações corporais, táteis dos personagens, mas não sabem muito bem o que aquilo significa para a narrativa.

Num determinado sentido, pode-se destacar que nos longas-metragens da cineasta, os espaços do cotidiano, o trabalho, a casa e os estados emocionais dos personagens estão submersos num aparente estado de imobilidade, desconexão e clausura que adquirem um novo sentido e nova temporalidade quando articulados com a banda sonora. Contudo, nos itens a seguir pretendo demonstrar como um espaço indiscernível é apresentado nos filmes desde os momentos iniciais das narrativas ficcionais, subvertendo o espaço visual mostrado nas cenas e impulsionando o espectador para perceber aquilo que se mantém além da visualidade, presente na imaginação dos personagens retratados. Na abertura de O Pântano, os sons fora de campo ligam três diferentes espaços apresentados para reforçar uma estranheza apresentada pelas imagens. O espaço torna-se indiscernível para o espectador que se mantêm 
preso numa teia de histórias acidentais até o momento no qual todas as histórias se unem a partir da escuta de um mesmo som que nunca se vê.

\subsection{As pequenas subversões acidentais na casa, na piscina, no cerro e na estrada: os espaços rarefeitos e as cadências evitadas nos filmes de Lucrecia Martel}

Nos três filmes analisados nesta dissertação, pode-se notar um jogo posto entre a visão e a escuta, e, muitas vezes, escutamos sons e vozes que mantém dúvidas sobre a sua fonte sonora causal. Ouvem-se respirações, sons ásperos, evaporações, vozes e ruídos do ambiente acústico da filmagem que não sabemos muito bem o que significam, mas conferem uma atmosfera misteriosa às narrativas. Como uma das práticas desse jogo, pode-se apontar em $O$ Pântano, uma organização da montagem que destaca a articulação entre som e imagem dada por pontos de sincronização deslocados ou evitados, que chamam mais atenção do que aqueles realizados.

Como exemplo, apontamos duas cenas: a primeira mostra o adolescente Joaca (Diego Baenas) apontando um rifle em direção a uma vaca atolada com a criança Luchi (Sebastián Montagna) entre sua mira, porém é a detonação do disparo que apenas chega aos ouvidos do espectador, já que a imagem é retirada para fora-do-quadro (figuras 9, 10 e 11); em outro exemplo, vemos a imagem de Momi (Sofía Bertolotto) correndo para saltar na piscina suja, porém retira-se a imagem do pulo na piscina deixando restar apenas o som da garota eclodindo sobre água parada e lodosa da piscina, sem nenhum sinal de Momi. Alguns segundos depois vê-se as costas dos adolescentes à beira da piscina. O último corpo a ser revelado é o de Momi, acariciando o cabelo de José (Juan Cruz Bordeu) (figuras 12, 13, 14 e 15). Esse tipo de articulação na montagem provocaria certo tipo de "cadência evitada" 
(CHION, 2011, p.52) ou mesmo uma "dissonância audiovisual" (idem, ibidem, p.36) que gera uma expectativa no espectador em relação à resolução dos acontecimentos sugeridos na narrativa.

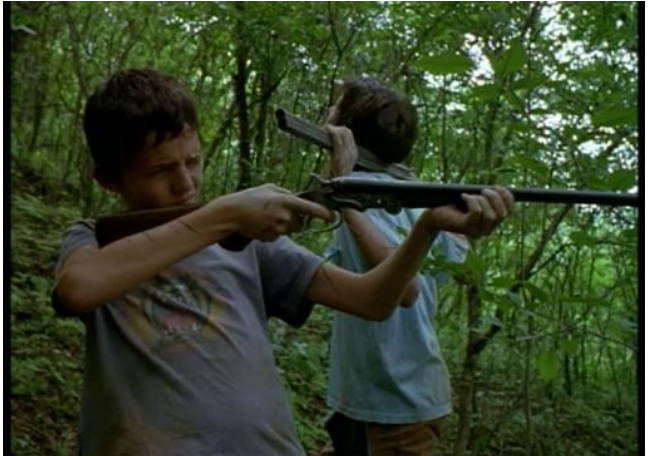

Figura 9.

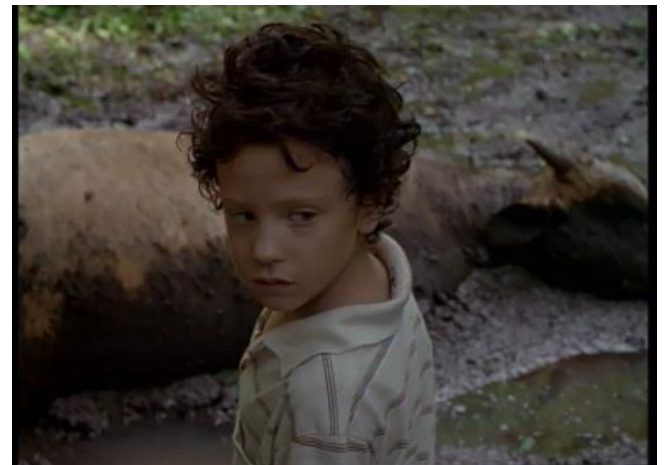

Figura 10.

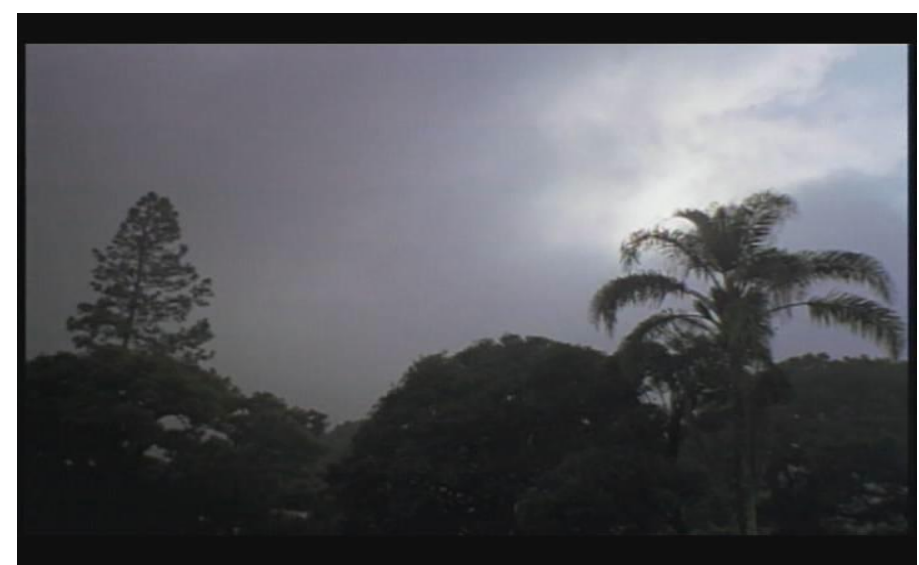

Figura 11.

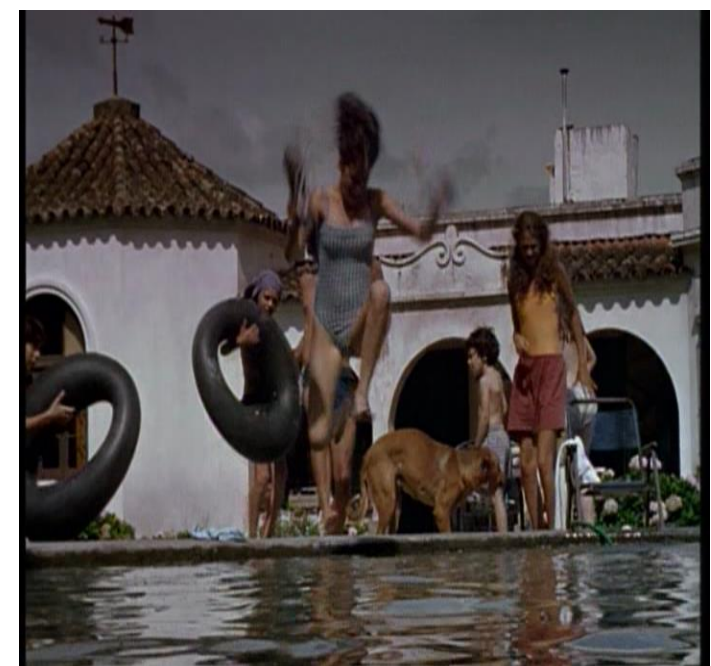

Figura 12.

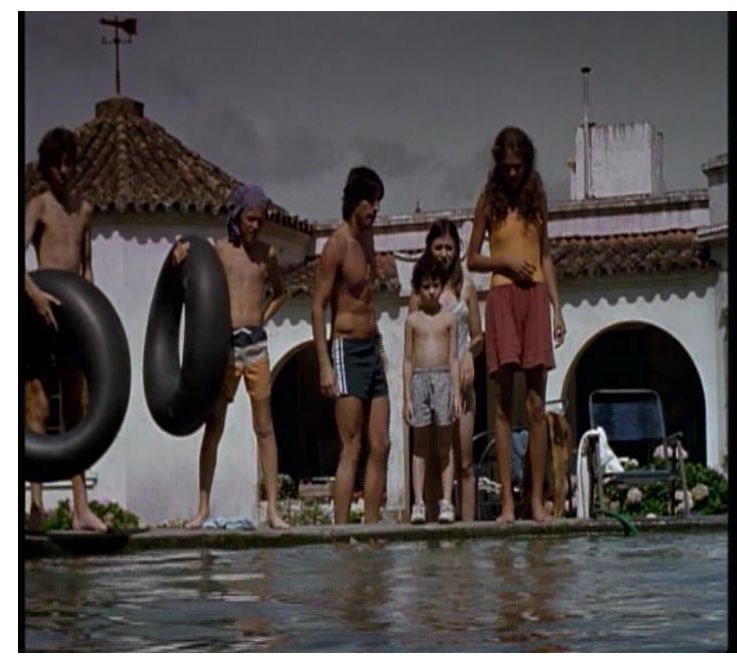

Figura 13 


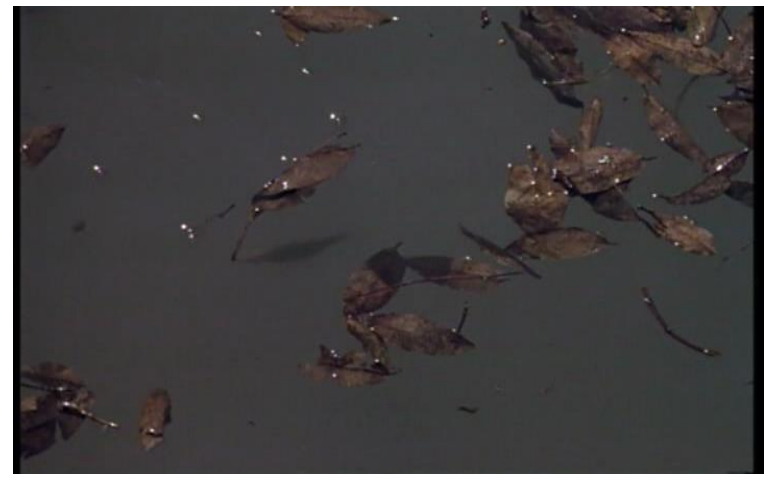

Figura 14

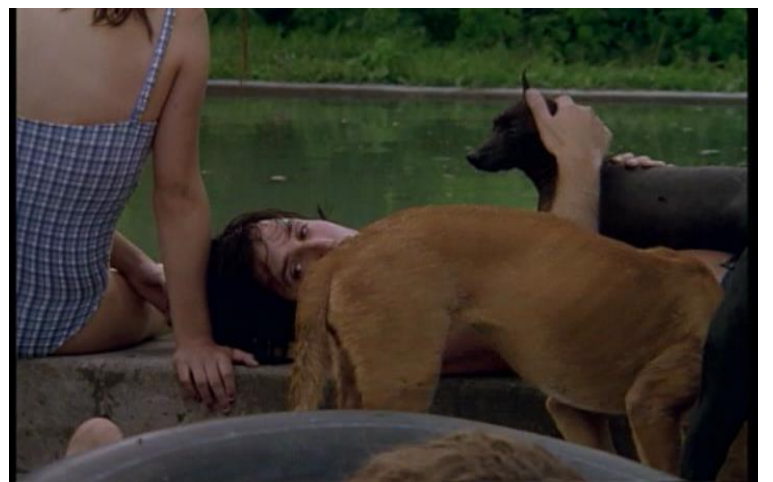

Figura 15.

Desde os primeiros planos deste filme podemos dizer que as coisas são insinuadas com “planos que registram as ações desde uma posição excêntrica e a decisão de ressaltar ou esconder determinados componentes da cena produz um tom levemente estranhado ${ }^{41 \text { ", }}$ (OUBIÑA, 2007, p.16). Com uma imagem que nos mostra os objetos e personagens a partir da fragmentação, a cineasta Lucrecia Martel constrói uma sequência de abertura onde pela articulação entre os planos não é possível alcançar nenhuma exatidão. Em "Estudio Crítico sobre La Ciénaga", o crítico argentino David Oubiña aponta que não temos na abertura deste filme, como convencionalmente no cinema narrativo, um plano geral (plano de estabelecimiento) que serve para descrever o lugar e situar os personagens nas coordenadas espaciais que orientam a percepção do espectador (idem, ibidem, p. 17). Ao contrário, em $O$ Pântano, a tormenta que ameaça cair no prólogo do filme e desata após o acidente de Mecha (Graciela Borges) seguirá com seu murmúrio trovejante instaurando a sensação da precipitação de uma ameaça que perseguirá os personagens até os últimos momentos do filme.

\footnotetext{
41 Tradução minha. "Los planos registran las acciones desde una posición excéntrica y su decisión de resaltar o asordinar determinados componentes de la escena produce un tono levemente extrañado". Ver OUBIÑA, David. Estudio Crítico sobre La Ciénaga. Buenos Aires: Picnic, 2007.
} 
Entre o acidente de Mecha e a morte de Luchi, a sensação de precipitação perdura como um instante prolongado. Instante prolongado que salta aos nossos olhos e ouvidos após os dois acidentes que marcam início e fim da narrativa. A impressão de uma suspensão do tempo como se a imagem estivesse congelada permanece logo após a queda de Mecha, quando ouvimos um ruído longo e estridente de taças quebrando. Este som que é dado no espaço fora de campo - já que não vemos a imagem da queda - atravessa a imagem fixa e em plongée do acidente para irromper reverberando pelo espaço da diegese e invadindo os próximos planos que mostram Momi, Isabel e Verô ouvindo o ruído.

No prólogo d'O Pântano, lidamos com sons de trovões, tiros, taças e latidos que conferem uma temporalidade estranhada em relação aos movimentos de inércia enfatizados pela imagem. Pode-se dizer que uma estridência ruidosa escutada por espectadores e personagens no momento da queda de Mecha inscreve o acontecimento acidental numa impressão de tempo real e irreversível. Atravessando os planos, esse som reverbera do espaço exterior para o interior da casa a fim de ligar o sentido de passado e do futuro através da sensação da precipitação de uma tragédia. A mulher que cai bêbada, mesmo após o acidente, continua ao longo do filme anunciando suas entradas em cenas através do som das taças de vinho. Em todas as cenas nas quais a personagem Mecha aparece vamos ouvir os sons vibrantes da sua taça.

Conforme Chion (2011) nos lembra em Audiovisão, "o valor figurativo e narrativo de um ruído, reduzido a si mesmo, é muito vago" (p.24), sendo que a representação de um acontecimento ou a efetuação de fenômenos sensoriais com ruídos seria dada menos por um realismo acústico do que através de critérios relacionados ao sincronismo e as convenções cinematográficas. Como influência do som sobre a percepção espaço-temporal na imagem Michel Chion destaca o efeito de "vetorização", presente no prólogo de Persona (Persona, 1966, de Ingmar Bergman), “onde imagens fixas e desprovidas de qualquer temporalidade se 
inscrevem num tempo real através de sons de água e barulho de passos" (CHION, 2011, p.1819).

Segundo Chion, este efeito dado pelo som marca no plano imagético um ponto no qual o tempo se orienta de maneira precisa através de ações causadas por forças irreversíveis, como os acontecimentos dados pelo efeito da gravidade (queda), do seu retorno à inércia ou mesmo pela explosão de algo que não pode ser revertido (idem, ibidem, p. 22-23). No exemplo apresentado no prólogo d'O Pântano, podemos constatar que o sentido de passado e futuro da ação - gotas caindo, a aproximação de passos e trovões - é marcado pela influência do som sobre a imagem ao criar uma sensação de eminência e expectativa em relação àquilo que está fora da visão dos personagens e espectadores.

Contudo, na linguagem cinematográfica a questão do tempo real também pode se referir à duração de um único plano (single shot), assumido como um plano que não é nem rápido, nem em slow motion, no qual a velocidade de projeção é igual a sua velocidade de reprodução (DOANE, 2002, p. 172) ${ }^{42}$. O tempo real dado pelo aparato em relação ao tempo da cena é destacado pela crítica Mary Ann Doane, antes de tudo, como um momento de "aparente plenitude" (idem, ibidem, p.172), que possui uma produção incessante de sentido a partir da contingência e, mesmo, da evacuação de sentido (idem, ibidem, p. 181). Para Doane, a experiência cinematográfica apresenta-se assim, profundamente, assombrada por uma lacuna no espaço; uma descontinuidade existente entre os planos que elide o tempo perdido representado pelos intervalos entre os frames (imagens fixas ou quadro). O cinema é

\footnotetext{
${ }^{42}$ Tradução minha. "In the technical language of filmmaking, the term real time refers to the duration of a single shot (assuming the shot is neither fast or slow motion). If the physical film is not cut and its projection speed equals its shooting speed [...], the movement on the screen will unfold in a time that is isomorphic with profilmic time, or what is generally thought to be our everyday live experience of time - hence the term real". Ver: DOANE, Mary Ann."Zeno's paradox: the emergency of a cinematic time". In: The Emergency of a Cinematic Time. Harvard College, 2002, p. 172. Conforme Mary Ann Doane (2002), o shooting speed está geralmente localizado entre 16 e 24 quadros por segundo. Para filmagem de O Pântano, (La Ciénaga ,2001) foi utilizada uma única câmera ARRI 535, a 24 quadros por segundo.
} 
apresentado pela autora como grande simulacro do tempo, produzindo o movimento contínuo ou mesmo uma impressão de movimento a partir de imagens descontínuas.

Contudo, Doane (2002) prefere apontar uma hipótese que parece destacar o movimento como a garantia da sua capacidade de captar ou armazenar o tempo, onde o movimento na tela pode se desdobrar em um momento que entra em isomorfia com o tempo de uma experiência vivida no tempo cotidiano. No entanto, na produção do sequenciamento de planos adotado pela linguagem cinematográfica, o intervalo foi disposto a partir de uma lógica que não coloca em causa a autenticidade e a autoridade do tempo de gravação. No capítulo "Zeno's Paradox: the emergence of cinematic time", a autora se debruça sobre uma pesquisa que busca responder como nos primeiros filmes aparecem pequenos procedimentos e lógicas de organização geral da diegese que mantinham esforço em criar uma relação coerente entre o espaço fílmico e o tempo. Para Doane (2002), já nos primeiros anos de cinema, a união dos planos continham diferentes níveis de significância. Conforme Doane (2002), três práticas de edição (a linearização, a perseguição e a montagem paralela) encontradas nestes primeiros filmes apontavam um tendência na construção da diegese cinematográfica - enfatizavam regras de continuidade clássica a favor de uma localização estável do espectador. No entanto, essa tendência pré-anunciada nos filmes do início do século XX, interessa-nos apenas pelas suas formas de desvios e mesmo, de subversão. Nas três películas de Lucrecia Martel, a construção do espaço fílmico não enfatiza regras, mas de alguma maneira, compreende-as para que se possa destituir o espectador do seu lugar estável.

Em $O$ Pântano, assim como em seus outros longas-metragens, o que é perdido pela invisibilidade não é preenchido pela dimensão da sua falta com uma repetição temporal (DOANE, 2002). Na sequência de abertura deste filme, observamos três ações diferentes intercaladas em montagem paralela que se ligam, inicialmente, apenas pelos sons acusmáticos: temos planos onde uma câmera móvel acompanha uma corrida que parece ser 
uma perseguição ou caçada com crianças e cachorros dentro de uma mata fechada; outros planos onde imagens cambaleantes mostram fragmentos de corpos em "estado de espera" à beira da piscina, com destaque para o corpo de uma mulher bêbada servindo taças de vinho ao que esperamos ser seus convidados; e imagens em plongée que mostram adolescentes deitadas em camas dentro de um quarto. A eminência de uma tormenta apresenta-se como um evento anunciado pelos sons que se sobrepõem às imagens instáveis instauradas pela caçada e que culmina no adolescente Joaca (Diego Baenas) apontando um rifle para uma vaca atolada em uma ciénaga e na queda acidental de Mecha. Em oposição, percebe-se o movimento lento dado pela languidez das adolescentes na cama e pela apatia dos adultos à beira da piscina. Os sons de taças quebrando e do tiro de um rifle sugerem o acidente de Mecha e a morte da vaca, mas não vemos nenhum destes acontecimentos. Adiante, os planos posteriores concentram-se na imagem do momento posterior à queda de Mecha, que detona a tormenta e liga os espaços da casa à beira da piscina.

De acordo com Doane (2002) esse tipo de relação entre os planos não seria dado pela adição ou acumulação de vistas diferentes de uma mesma ação (lógica da perseguição), muito menos pela relação de coerência entre o espaço e o tempo fílmico (lógica da repetição), mas pela contaminação de elementos permeados pela ansiedade, pelo desejo ou pela ameaça, próximos a uma lógica da dramatização do tempo, empreendida nos filmes de suspense (p.187, 195-196). Desde os primeiros momentos em $O$ Pântano, os sons do espaço externo à casa aparecem na narrativa como uma ameaça não identificada em relação a família de Mecha, apenas sugeridos pela eventualidade deste primeiro acidente (figura 16). Se a montagem paralela foi uma das primeiras lógicas de montagem usadas pelos filmes de suspense, sendo definida como um corte alternado entre duas cenas que são assumidas para ter, de alguma forma, uma relação com a outra que pode ser compreendida como simultânea ou quase simultânea, no caso d'O Pântano, a simultaneidade de eventos no início do filme é 
representada pela sucessão de cortes (cut-in) que interrompem a ação imagética, gerando uma duração que é intensificada pela incapacidade de ver tudo.

O filme avança com outro acidente que apresenta a casa da família de Tali, prima de Mecha. Um corte na perna da criança Luchi (figura 17) é motivo para uma ida ao hospital, onde as famílias de Mecha e Tali se encontram. Martel escolhe não nos mostrar este acidente, mas o seu momento posterior. Durante alguns dias, não se sucede nada mais. Observamos muito próximos do ponto de vista da filha mais nova de Mecha (Momi, interpretada por Sofia Bertolotto) os momentos de ócio do cotidiano de férias das famílias. As duas famílias se reencontram, as crianças transitam entre os espaços das duas casas, mas com exceção de uma única cena na estrada, nunca observamos tais transições e deslocamentos entre os espaços.

Como aponta David Oubiña (2007), não observamos um único evento ou ação que culmina na espera da sua resolução, mas observamos a "acumulação de pequenas coisas"43 (OUBIÑA, 2007, p.33), como quando Tali comenta que Mercedes (Silvia Baylé) foi amante do marido de Mecha, Gregório (Martín Adjemián); com Mecha pedindo para Gregório dormir no quarto dos fundos; com Rafael (Daniel Valenzuela) marido de Tali comentando que a casa
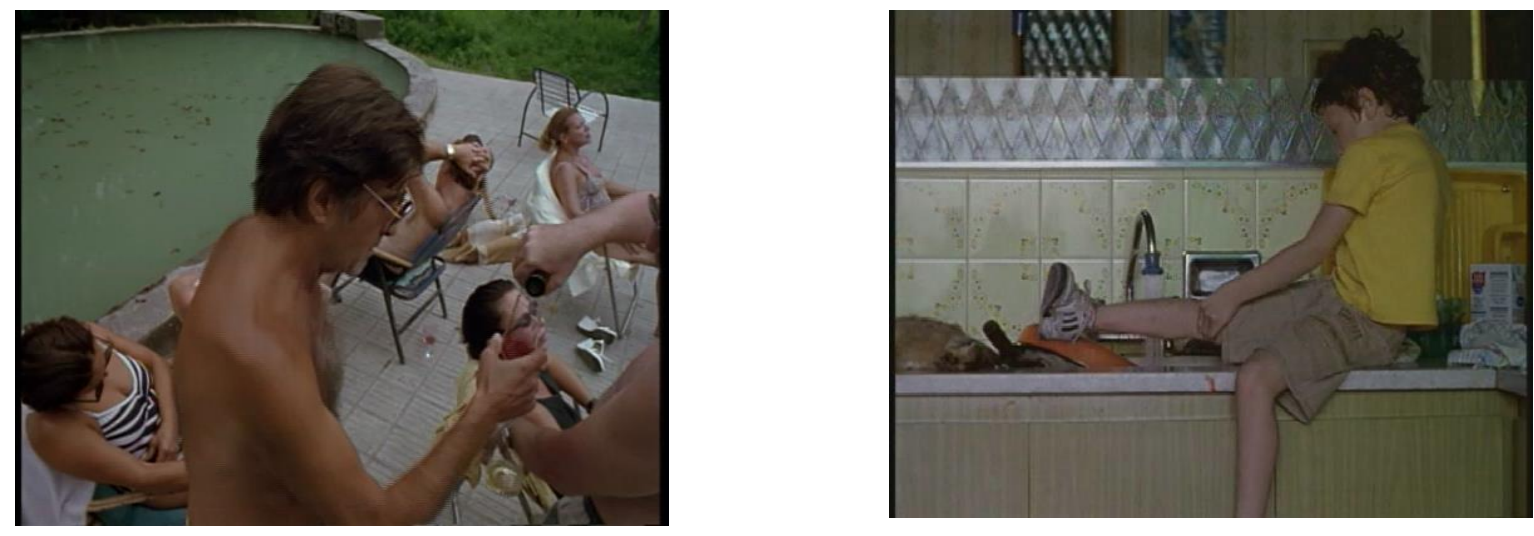

43 Tradução minha. "Esa "acumulación de pequeñas cosas" surge de las mínimas distancias entre quienes parecen semejantes o bien los puntos de contacto entre los que deberían mantenerse alejados." Na citação, o autor se refere diferença entre as personagens femininas, Mecha e Tali, apresentadas no filme através de gestos íntimos e semelhantes entre as duas, mas que vivenciam um dia-a-dia completamente direfentes. Na casa de Tali, a mulher aparece completamente submetida ao marido que impõe seu ponto de vista de maneira firme. Na fazenda de pimentões de Mecha, a casa é governada pela matriarca que mantém desprezo pelo marido que não faz nada. (OUBIÑA, 2007, p. 33) 
de Mecha "es un desastre". A decadência e desorganização familiar presente na casa de Mecha é contraposta ao lugar seguro da casa de Tali, onde de alguma maneira, a voz masculina ainda se impõe dentro de uma ordem familiar (Acima, temos as figuras 16 e 17).

Na casa de Tali (Mercedes Moran), além da voz impositiva do seu marido, ouvimos aparelhos de tv ligados, apitos da panela de pressão, a algazarra das crianças brincando e os latidos de um cachorro vizinho - som fora de campo que nunca vemos. Esse latido pontua insistentemente as cenas na casa de Tali anunciando um acidente que ainda está por vir. O latido do cão, escondido atrás de um muro vizinho, incita a curiosidade de Luchi, filho mais novo de Tali, que ao tentar ver o cão do outro lado do muro, caí da escada e mantêm-se desfalecido. Nesta cena, assim como no acidente de Mecha, não vemos o momento da queda, mas planos com momentos antes e depois do acontecimento. A ameaça externa novamente é dada por uma situação acusmática e gera um momento de suspensão num local onde por muitas vezes os personagens transitaram despretensiosamente. Este acidente, marcado por um momento de "plenitude aparente" (DOANE, 2002), ao contrário do ruído estridente das taças que irrompem na cena de Mecha, é dado pelo silêncio e pelo encadeamento de quatro planos seguintes que mostram os ambientes vazios da casa de Tali.

Para o crítico argentino Gonzalo Aguillar (2010), os quatro últimos planos após o acidente mostram uma rarefação ou diminuição de intensidade em relação a planificação do início do filme, através do efeito de diminuição dos fenômenos expressivos apresentados nos planos. Para Aguilar, com a rarefação da intensidade, "trata-se de recuperar a compostura depois que a narração se estilhaça, resolvendo a um só golpe e abruptamente uma diversidade de historias que estavam em jogo"44 (idem, ibidem, p. 49). Conforme o autor, se, em princípio

\footnotetext{
44 Tradução minha. "Tratan de recuperar la compostura después de que la narración ha estallado, resolviendo de un solo golpe y abruptamente la diversidad de historias que estaban en juego". (AGUILAR, 2010, p. 49)
} 
o acidente de Mecha e as suas relações familiares com Tali (Mercedes Morán), Momi (Sofía Bertolotto), Isabel (Andréa Lopez) e José (Juan Cruz Bordeu) aparecem misturadas e determinantes na narrativa, no final, a narração elege um acidente fatal com o personagem "mais inocente" da história, Luchi (Sebastián Montagna) (idem, ibidem, p.49). O encadeamento dos planos dos ambientes vazios (figuras 20, 21, 22 e 23) aparecerem para reorganizar aquilo que se apresentava fora de controle, como ameaça eminente à narrativa.

Neste tópico, destacamos que em $O$ Pântano, os acontecimentos que acontecem no espaço fora de campo nos foram apresentados pela precariedade de momentos acidentais. Instantes que escapam num tempo elidido através de uma narração que subverte as ordens e lógicas da linguagem audiovisual para incorporação das lógicas do azar. A lacuna criada pela perda da referencialidade da fonte sonora dada no espaço fora de campo, mesmo que por alguns segundos, e pelo uso de um ponto de sincronização evitado são determinantes para pontuação e quebras de temporalidades diversas, além da demarcação de instabilidades neste filme.

Neste sentido, apontamos que uma constante repetição dos mesmos ambientes mostrados pela imagem - os espaços físicos do cerro, da piscina e as duas casas - os quais nunca se fazem ver pela sua totalidade completa em um plano geral, faz com que tenhamos a sensação de que os personagens não transitam entre os espaços. O desarranjo ou a subversão de um tempo e espaço linear estabelecido geralmente pelo uso do plano geral que apresenta os personagens situados no espaço, como destacado pelo crítico David Oubiña, proporciona aos espectadores fragmentos de imagens que impossibilitam a definição exata do lugar e do tempo em que se encontram os personagens. Uma série de impedimentos que se dão na narrativa, o uso do enquadramento axial e de planos curtos, no início deste filme, reforçaria essa sensação de clausura dos personagens naqueles espaços, presos à espera da queda de uma tormenta. Como destacado por Aguilar (2010), a suposta morte da criança Luchi, em $O$ 
Pântano, faz com que todas as sensações precipitadas e eminentes se encaminhem para convergir em uma grande pulsão de morte (DELEUZE apud AGUILAR, 2010, p. 50), encerrando os personagens na constatação de um destino imutável, trágico. Ironicamente, podemos destacar que neste filme, os únicos planos que nos mostram uma visão geral do espaço da casa são os quatro planos vazios que se sucedem após a morte de Luchi.
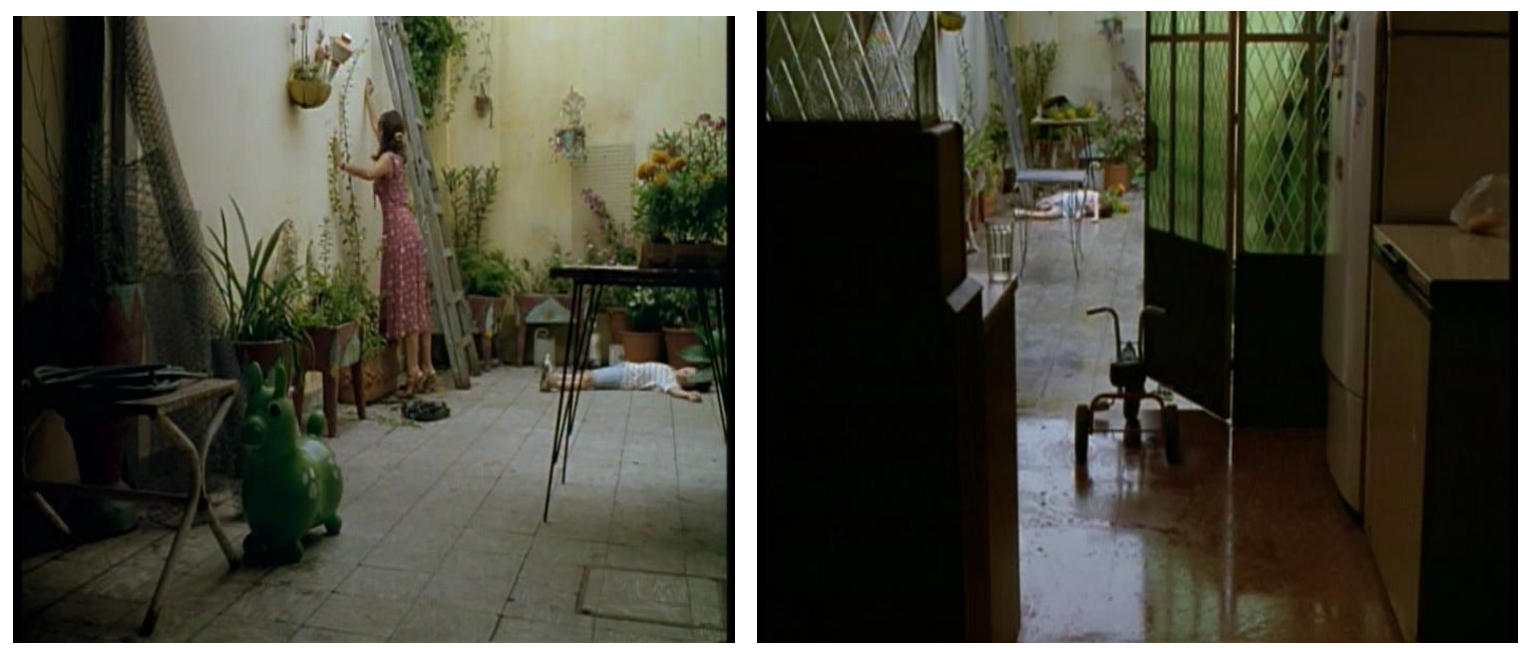

Figura 18 e 19. Ao longo deste filme, por diversas vezes, a morte de Luchi é incitada como uma brincadeira infantil. Na figura 11, podemos ver o plano onde Luchi é assassinado numa brincadeira com outras crianças. Na figura ao lado (12), Luchi aparece quase na mesma posição em um dos últimos planos, morto após uma queda da escada.
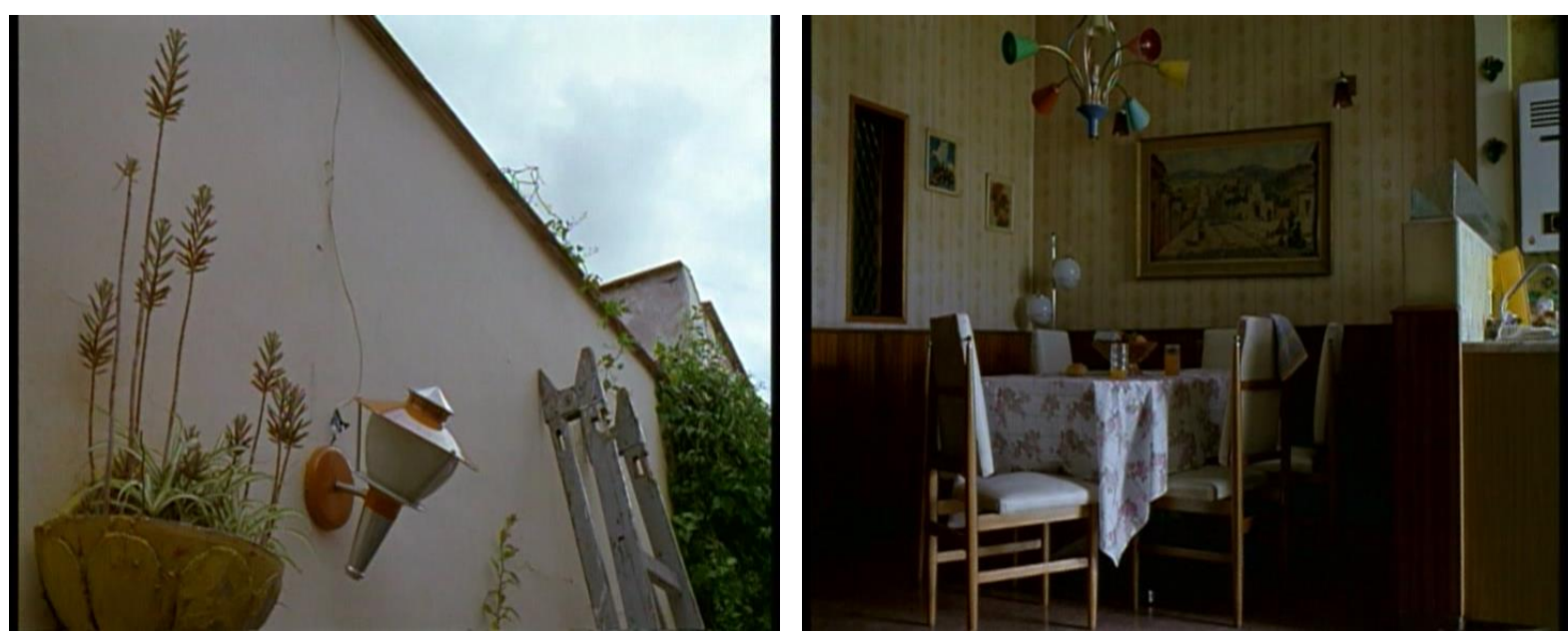

Figuras 20 e 21 (acima). Figuras 22 e 23 (abaixo). 

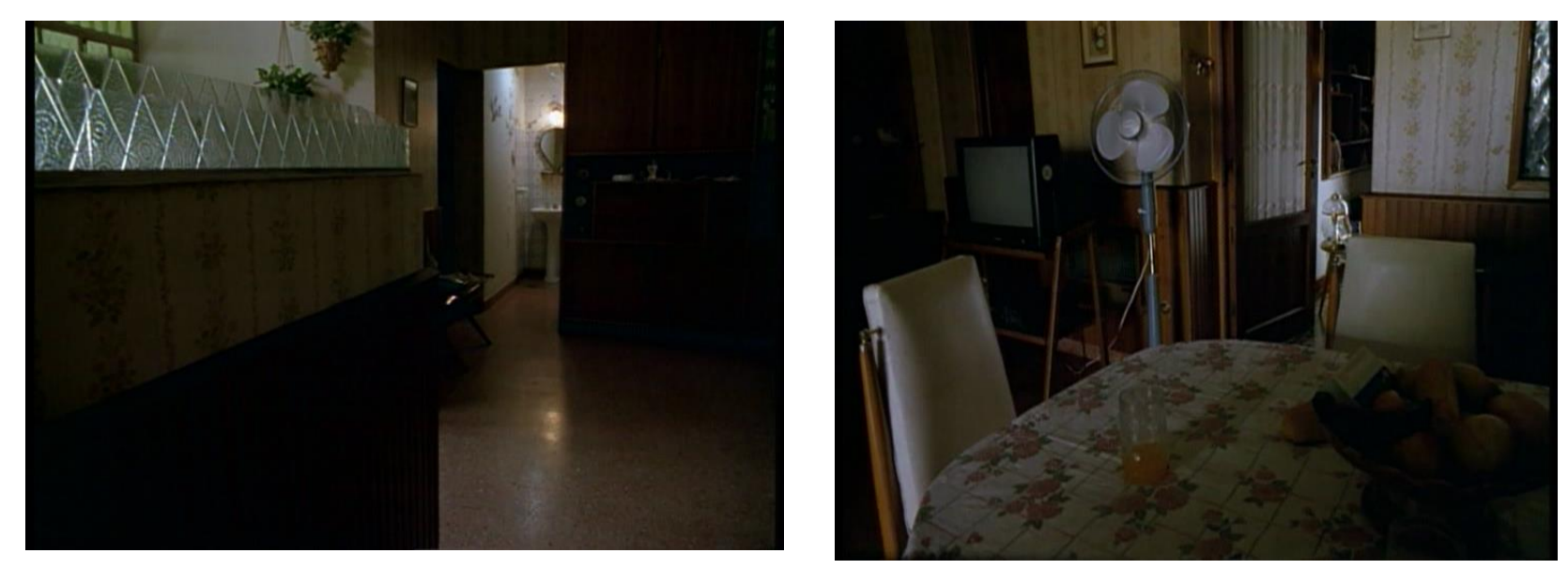

\subsection{Es siempre lo mismo}

Metaforicamente, podemos perceber o comportamento dos corpos inertes dos personagens nos filmes de Lucrecia Martel semelhantes à imagem da vaca atolada nas ciénagas formadas no verão. Nestes pequenos alagadiços formados pela água do degelo das montanhas, os corpos pesados dos animais afundam quanto mais movimento se produz para sair do lamaçal. A vaca atolada na lama, uma das primeiras imagens que aparece em $O$ Pântano permanece imóvel mesmo com a agitação provocada pela chegada das crianças e dos latidos dos cachorros. Outra imagem - que também surge nos primeiros instantes deste filme mostra corpos embriagados, bronzeados e sudorosos que se movem quase imperceptivelmente cambaleantes arrastando cadeiras à beira da piscina. Nos próximos planos, vê-se os mesmos corpos largados sobre as cadeiras (figuras 24, 25 e 26) e, mesmo quando uma senhora cai sobre taças de vidro quase ninguém se move para socorrê-la - a exceção das garotas Momi, Verónica e Isabel - como se estivessem vivendo um acontecimento que habitualmente se repete naquele lugar.

Nestas imagens do filme $O$ Pântano, os corpos dos personagens parecem estar acometidos por uma sensação semelhante à sensação vivida pela vaca atolada que cedeu ao 
cansaço e afunda no lamaçal. A partir destas imagens de abertura, tudo se sucederá como se uma força tectônica atraísse todos os personagens "para um fundo imóvel que lhes impede de agir”,45 (OUBINA, 2007, p.21 ). Uma corporalidade pesada, densa, e um tempo espesso manterá a figura do cansaço presente nas imagens seguintes d'O Pântano.

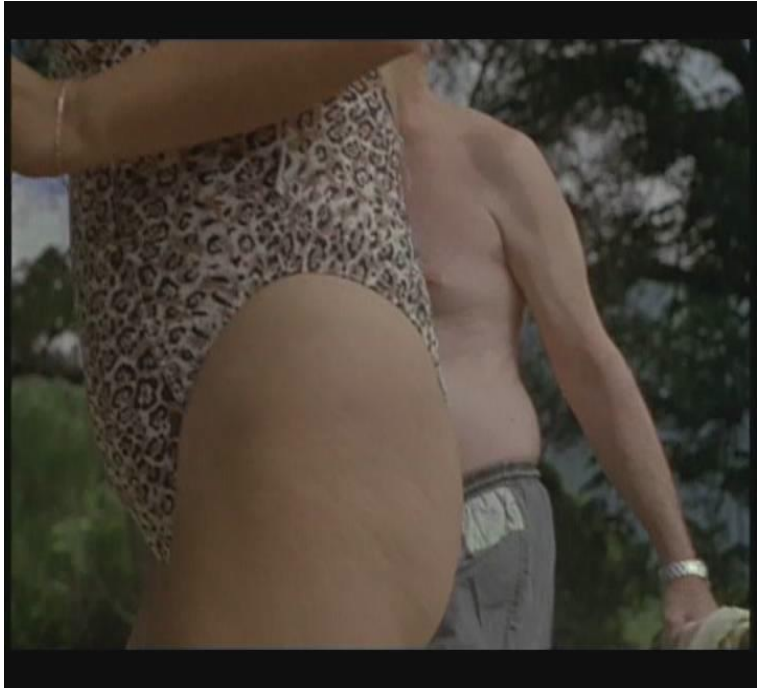

Figura 24.

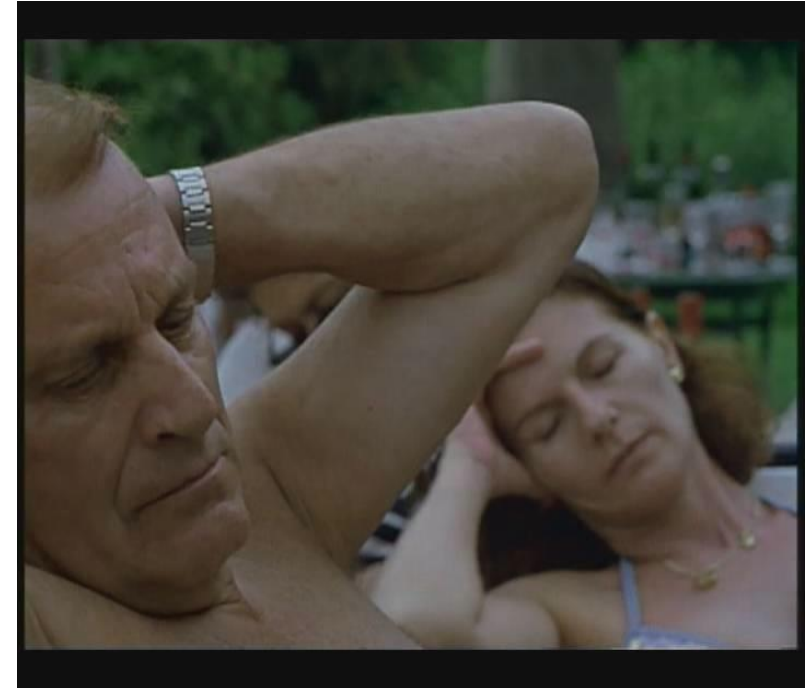

Figura 25.

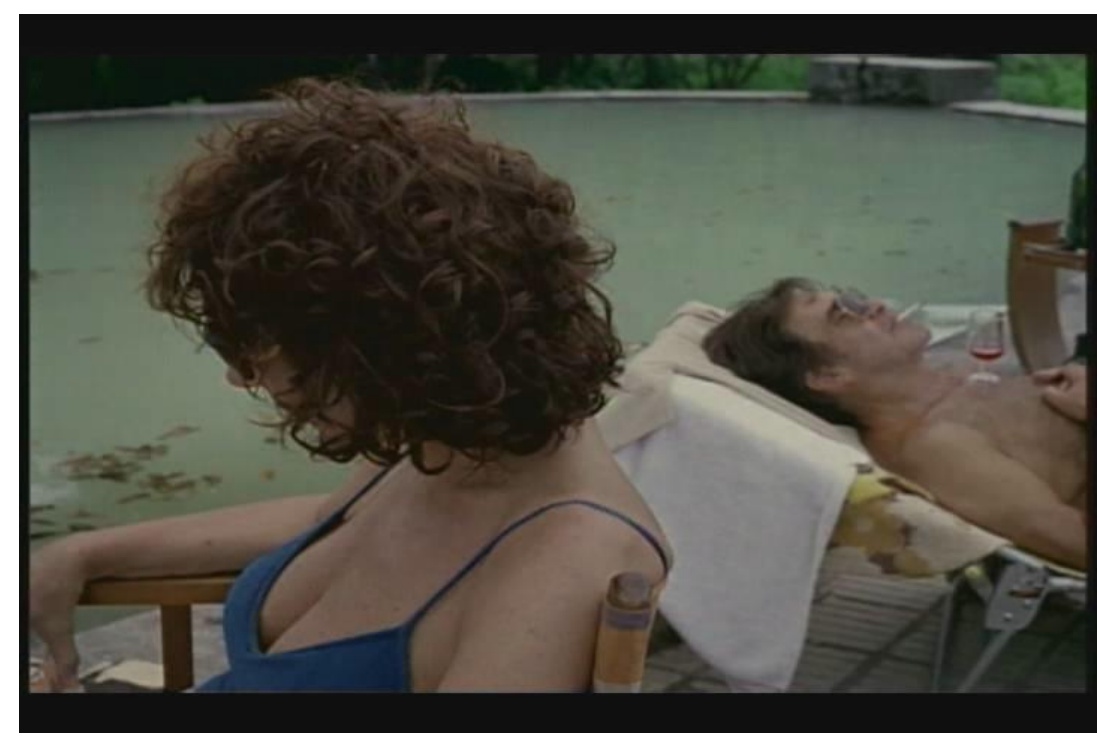

Figura 26.

45 Tradução minha. "El de La Ciénaga es un tiempo espeso que arrasta a los personajes hacia un fundo inmóvil y les impide actuar. La metáfora, aquí, es la siesta: la eternidad suspendida de esas siestas de verano, pobladas de historias legendarias y tremebundas" . Ver: OUBINA, David. Estudio Crítico Sobre La Ciénaga. Buenos Aires: Picnic, 2007. p. 21. 
Em 2001, ano do lançamento deste filme, as imagens descritas acima povoaram o imaginário de muitos ao redor do mundo. Na maioria das análises dos críticos de cinema argentino, essas imagens eram ressaltadas por darem acesso a um fuera-del-tiempo de alcance simbólico que retomavam as figuras de um derrumbe, da precipitação e das ruínas (AMADO, 2009; AGUILAR, 2010; ÕUBINA, 2007) de uma "formação sócio-econômica" liberal da Argentina. A retenção em um espaço através de uma força invisível infiltrava-se por todos os lados e foi descrita como "uma mesma pulsão de parasitismo" (DELEUZE apud AGUILAR, 2010, p. 50) que seria ressaltada nos filmes de Martel pelas modalidades de tempo que a cineasta constrói. Este tipo de organização do espaço, como vimos nas pontuações de Gonzalo Aguilar (2010), alimenta-se de cadências evitadas e espaços rarefeitos para convergir todos os elementos do filme em torno de um "imenso campo de dejetos ou em um pântano, onde o desejo dos personagens nunca será poderoso o suficiente para motivar a violência de uma transgressão" (idem, ibidem, p.50). Ao contrário, os desejos dos personagens transitam em torno da eminência de uma queda aparentemente suscitada pelos vários acontecimentos acidentais que surgem alimentando as narrativas. A sensação de clausura e de uma imobilidade dos personagens é reforçada pela reiteração dos espaços que nunca se fazem ver pela sua totalidade completa - a piscina, o cerro e os cômodos da casa - e pela repetição geracional de histórias dentro de um mesmo núcleo familiar.

Também para Oubiña (2007), na primeira película da cineasta a impressão da "imobilidade", de uma "suspensão do tempo" ou "de um instante prolongado eternamente" seria reforçada pela circularidade dos vínculos entre os personagens (OUBINA, 2007, p. 21). Na lenta decomposição de um núcleo familiar, a ideia da repetição das histórias geracionais aparece na insinuação de uma relação sexual proibida entre Mercedes (Silvia Baylé) e 
Gregório (Martin Adjemián) no passado e, retorna na relação entre Mercedes e José (Juan Cruz Bordeu) no presente, respectivamente, o marido e o filho mais velho de Mecha (Graciela Borges). Diversas vezes, em frases curtas de advertências ou sobreavisos soltos em meio às conversas dos personagens ouvem-se rumores sobre fatos do passado que ameaçam repetir-se novamente. Apontamos como exemplo, uma das poucas cenas de trajetórias que mostra o deslocamento de personagens entre diferentes espaços ${ }^{46}$ - uma estrada que liga o caminho entre a casa de Tali e a fazenda de Mecha (figura 27). Tali (Mercedes Morán) aparece dentro do carro advertindo ao seu marido (Rafael, interpretado por Daniel Valenzuela) que é necessário falar sobre alguns temas, como o caso de Gregório e Mercedes, perante as crianças "porque si no, después es peor: la historia se repite" (figura 28).

Insistindo sobre a ideia de uma repetição destacada por David Oubiña, podemos também relembrar outro trecho deste filme, uma aparição de Mecha no fundo do corredor da sua casa - depois de um plano que a mostra parada olhando para o quarto escuro aonde Gregório (Martín Adjemián) dorme no meio da tarde (figura 29). A personagem cambaleando vagarosamente atravessa o corredor, alternando entre gritos e sussurros para que alguém "atenda el teléfono" e constata que naquela casa tudo "es siempre lo mismo! As frase ditas em diferentes momentos, surgem com um sentido de advertência para a família de Tali e como um diagnóstico para a família de Mecha. A transição entre os estados corporais de sobreavisos, sustos, inquietudes e a constatação de um sintoma parecem ser a sugestão daquilo que Martel pretendeu construir numa posição concreta, elegendo procedimentos

\footnotetext{
${ }^{46}$ Oubiña destaca como tema do filme "O Pântano", a representação de um mundo asfixiante e sem saída a partir de um recorte sobre o horizonte das economias regionais tradicionalistas. Conforme o autor, a película observa o mundo decadente de Mecha em La Ciénaga desde um ponto de vista da personagem Momi - sem adotá-lo literalmente em relação à câmera. A personagem também prognostica que "Mecha va a terminar prostada en su cama, igual que la abuela" (2007, p.15). A caçula de Mecha é a única que tem o ímpeto de manifestar-se contra essa repetição decadente e geracional que culmina em acidentes trágicos, ligando as famílias de Tali (Mercedes Morán) e Mecha (Graciela Borges). Os personagens formariam uma rede de pessoas em torno desse sistema, percebendo as coisas intensamente e extremamente sensíveis como se imutáveis e transmitidas de uma geração à outra. Ver capítulo "El pantano y la siesta" em Estudio Crítico sobre La Ciénaga: entrevista a Lucrecia Martel. Buenos Aires: Pic Nic Editorial, 2007.
} 
formais para com imagens, sons e posições corporais dos personagens construir uma experiência que assumisse os prazeres da lentidão até os últimos momentos do filme.

Dentro de uma perspectiva psicanalítica, a proliferação ou repetição de um sintoma aparecem à falta de elaboração psíquica do sujeito e manifesta-se aparentemente como desordem corporal. O esvaziamento da palavra, das atividades simbólicas, dos laços sociais familiares e sociais se localizam num tempo perdido para os personagens; fuera-del-tiempo do inconsciente e num espaço subjetivo (KRISTEVA, 1999). A repetição de um sintoma atuaria na tentativa da sua inclusão dentro da ordem do simbólico. Poderíamos pensar assim, que a atitude de Tali (Mercedes Morán) ao assumir a ameaça da repetição de uma situação familiar indesejada seria uma tentativa de trazer a história desta família para dentro da ordem do simbólico.

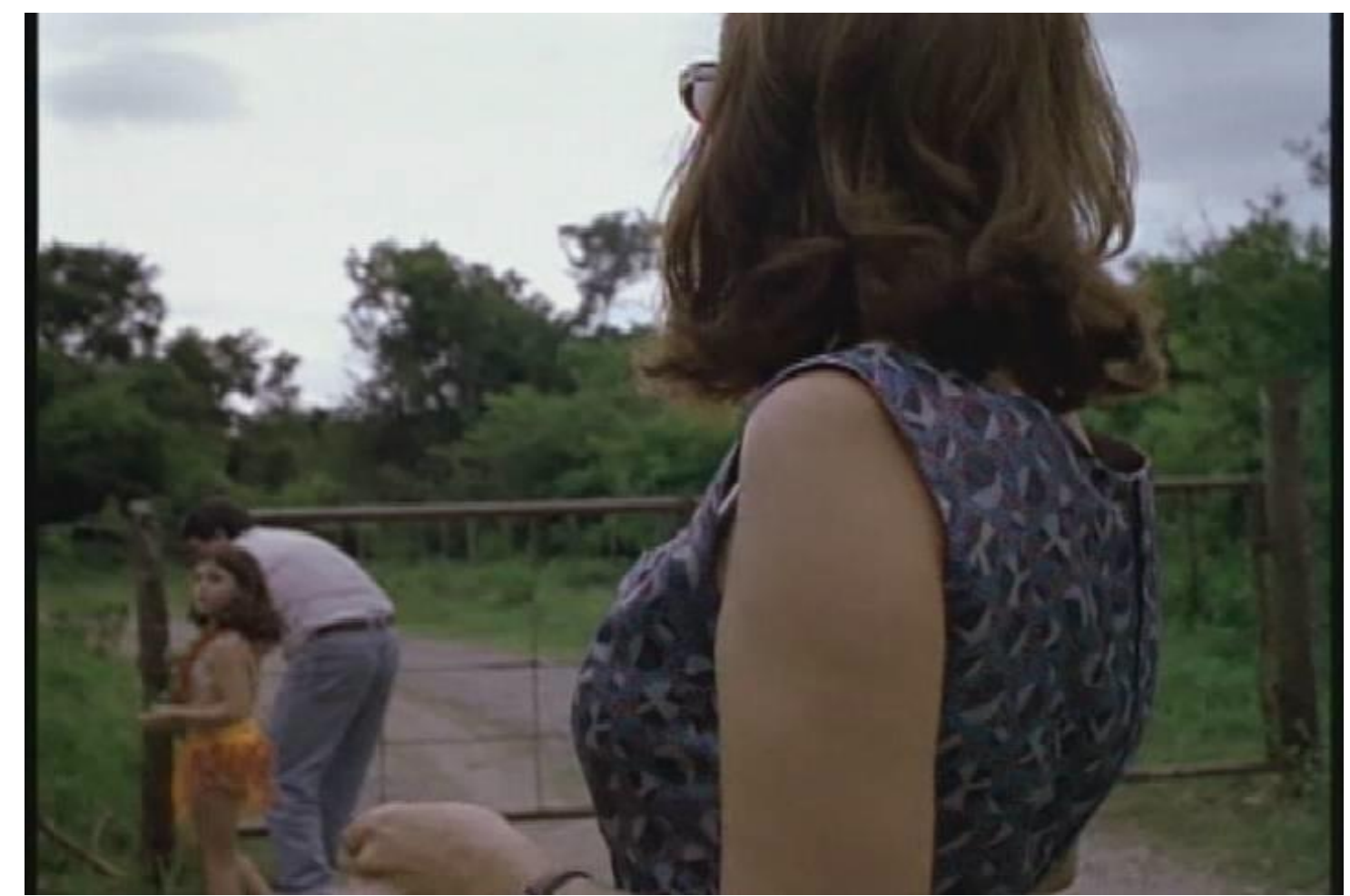

Figura 27. 

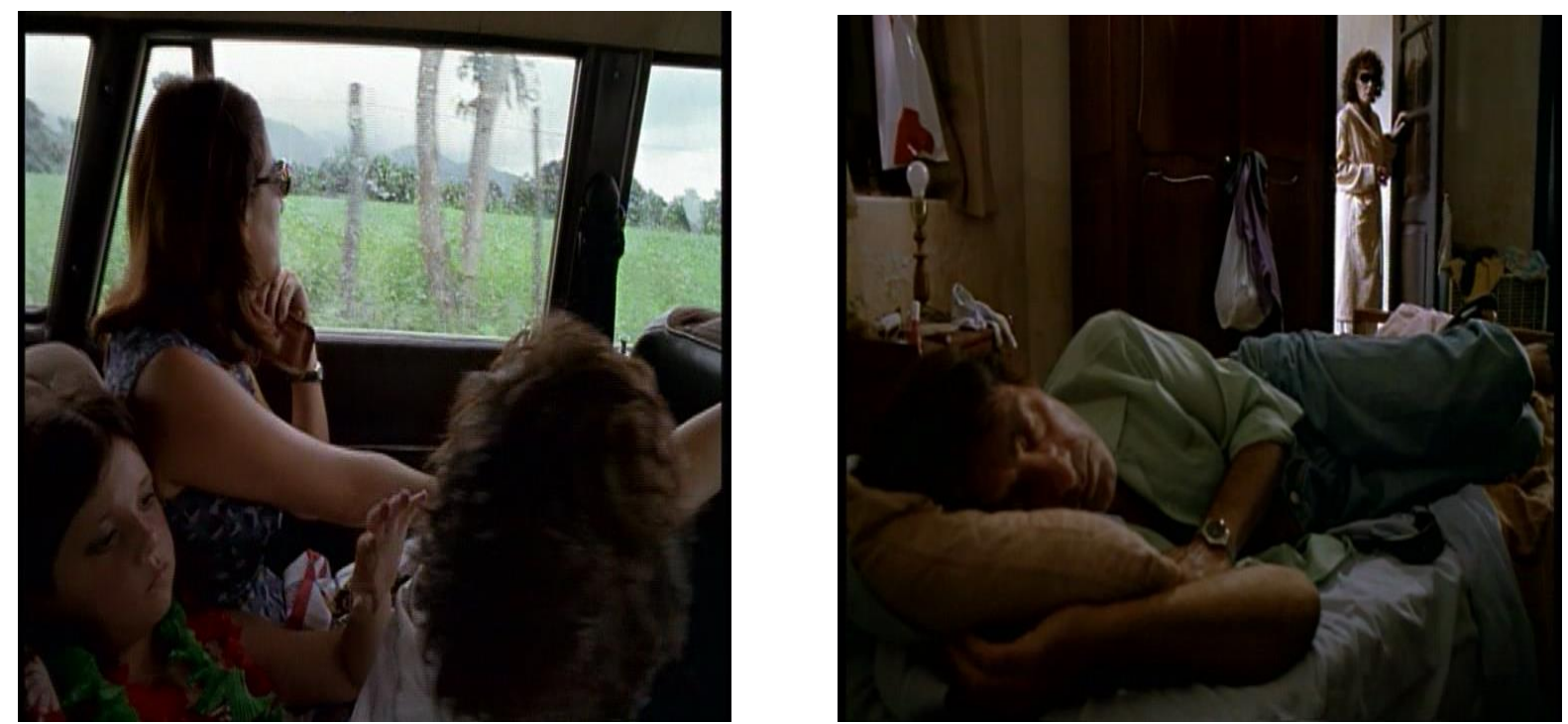

Figuras 28 e 29.

Desse modo, a experiência da repetição do mesmo não aparece como uma repetição temporal, mas é insinuada a partir dos gestos, sons e palavras que atravessam a cena atentos à subjetividade dos personagens, para criar diversas aproximações ao tempo. Enquanto Mecha sussurra um diagnóstico para si mesma, Tali adverte às crianças da ameaça de uma afasia familiar, ignorando o fato de que mesmo o sujeito falante pode ainda ser acometido por uma paralisia auditiva e não ouvir à tempo os sinais para se desviar das grandes tragédias da vida. Podemos relembrar que é a partir de uma audição paralisada pela contemplação de uma melodia - que repetida dentro da narrativa surge trazendo a lembrança de um momento de felicidade que já passou - que a personagem Tali se distrai e não percebe o distanciamento da criança Luchi que se encaminha para o quintal, sobe numa escada, se assusta com o som do latido do cachorro, cai e sofre um acidente fatal.

Como destacado por Gonzalo Aguilar (2010) nas imagens finais deste filme, a queda da criança fecha o ciclo da decomposição, de uma queda anunciada nas primeiras imagens do acidente de Mecha que contaminaria até os mais "inocentes", crianças que ainda acreditam em contos e lendas de ratas-africanas e na salvação de santos e virgens. A última fala de 
Momi - "no vi nada" - encerraria o conflito entre crença e desejo, apenas esboçado nas cenas onde os personagens assistiam as reportagens da televisão que mostravam a peregrinação de fiéis a uma caixa d'água aonde aconteceu uma aparição da Virgem Santa. Na cena final, a adolescente Momi encerra o filme com a repetição do primeiro gesto da mãe mostrado nesta película - o arrastar vagaroso da cadeira, retomando a temporalidade de uma siesta para revelar que a crença permanece "sempre fora" (AGUILAR, 2010, p.97) daquele espaço, presa na virtualidade de uma imagem televisiva. A frase em si aparece numa acepção negativa, como única condição de existência "no - vi nada", onde o prazer de ver a si mesmo e ao outro aparece vetado pelo simbólico.

Também em 2001, outros cineastas foram associados a outro grupo de imagens, todas destacadas como figurações subjetivas de uma crise Argentina. Em La Imagen Justa: cine argentino y política (1980-2007), a pluralidade de eventos históricos-políticos que compreende o período da configuração dessa crise - o acúmulo de anos de estagnação econômica entre os anos de 1983 à 2001 - foram relacionados pela crítica e professora de cinema Ana Amado (2009), com as manifestações estéticas e políticas de impacto na memória individual e coletiva da sociedade argentina. Através de experiências sensoriais da luz, do tato e dos sons de obras visuais criadas e/ou apresentadas (no caso das performances e instalações) neste contexto, Amado destaca a operação da construção de imaginários estéticos e políticos que revisitam algumas "invenciones de la Historia a través de la memoria":

Desde a metade dos anos noventa, o chamado Nuevo Cine Argentino, a cargo de uma jovem geração de cineastas, dialoga com o tempo social e político a partir de reiteradas coordenadas temáticas - memória, pobreza, exclusão, margens -, em propostas formais cuja compreensão ilumina os cenários de crise numa expressão local e/ou regional e de dilemas que estão também instalados nas sociedades globalizadas e de massa (AMADO, 2009, p. 17$)^{47}$.

47 Tradução minha. "Desde la mitad de los años noventa, el llamado Nuevo Cine Argentino, a cargo de una 
Neste livro, Amado (2009) apresenta um panorama de figuras da memória social do cinema argentino, escapando do peso que as imagens da vaca atolada ou dos corpos arrastando cadeiras de La Ciénaga carregam para relacionar outras imagens das películas de Lucrecia Martel e outros cineastas argentinos que exemplifiquem uma figurabilidade mais plástica e com elementos mais ambíguos.

Para Amado o caminho escolhido foi apontar como o movimento dos corpos e gestos organizados na forma de figuras inertes constroem um jogo visual e narrativo nos termos de “figurações íntimas de uma revolta” (KRISTEVA apud AMADO, 2009, p. 53). Na última parte do seu livro, a autora se concentra na reflexão de uma pergunta já lançada antes por Julia Kristeva ${ }^{48}$ sobre como a política se restitui através de novos universos simbólicos de representação? A resposta é dada pela autora através de um recorte sensorial da cinematografia argentina, ressaltando as maneras de acercase do político a partir dos modos de percepção do sensorium, da corporalidade e de um arcaico psíquico. A partir deste recorte, Amado busca relações entre política e o cinema argentino que foram problematizadas através de filmes e outras manifestações artísticas que não tentam explicar sociologicamente as transformações sucedidas na sociedade argentina.

Destacada no início deste tópico, a figura do cansaço (já sugerida no final do segundo capítulo numa acepção barthesiana da fadiga) apresentou-se até aqui distante dos horizontes políticos da sociedade argentina. Conforme Amado (2009), o cansaço como uma figura da

\footnotetext{
joven generación de cineastas, dialoga com el tiempo social y político a partir de reiteradas coordenadas temáticas - memória, pobreza, exclusión, márgenes -, en propuestas formales cuya comprensión ilumina los cenarios de las crisis em la expressión local y/o regional y de dilemas que están también instalados en las sociedades globalizadas y massivas" Ver: AMADO, Ana. La Imagen Justa: cine argentino y política (19802007), 2009, p. 17.

${ }^{48}$ Os livros citados por Ana Amado em referência a obra de Julia Kristeva são Sentido y sinsentido de la revuelta, (1999) e La Revuelta Íntima (2001).
} 
subjetividade presente nos filmes de Martel aparece na pesquisa da autora a partir de um pequeno desvio de sentido das análises de Deleuze sobre as obras do escritor Samuel Beckett (AMADO, 2009, p.210). Amado usa o sentido de cansaço para descrever um estado vivido pela sociedade argentina - como um clima de "enrarecimiento" social causado pelo acúmulo dos anos de crise, onde se destaca o correlato iconográfico da cama (idem, ibidem, p. 217), objeto reiterado insistentemente nas três películas dessa cineasta. Conforme Amado (2009), a figura do cansaço aparece como uma experiência íntima aludida pela circulação reiterada das camas, sendo que nos filmes de Martel o cansaço dá passo a uma variante familiar do esgotamento. No início do capítulo "Cansancio y Precipitación”, Amado diferencia o cansaço de um esgotamento:

\begin{abstract}
o cansaço, em seu sentido literal, pode ser descrito como uma condição psíquica sentida pouco a pouco como um fardo ou uma fadiga, mas também é simultaneamente um disparador da revolta; da identificação com a adesão e o reconhecimento do "outro" nas figuras de margem, enquanto suas filiações biológicas ou metafóricas. Para falar do cansaço, me refiro à idéia de Deleuze em formar um par com o esgotamento, uma vez que ambos os termos formam uma equação de proximidade e de distância aos seus significados. Ambos configuram uma imagem adequada de uma sociedade que tenta recriar seus laços comunitários sem sofrer a interferência dos poderes políticos que encurralam os cidadão através de uma via econômica: algo que podemos traduzir aproximadamente como o esgotamento do Estado, em paralelo ao cansaço generalizado dos cidadãos ${ }^{49}$ (AMADO, 2009, p. 217).
\end{abstract}

Trata-se de uma leitura sobre a diferenciação cunhada por Gilles Deleuze entre

\footnotetext{
49 Tradução minha. "Cansancio en su sentido literal, es decir como condición psíquica minada por el agobio y la fatiga, pero simultáneamente como disparador de la revuelta; de la identificación como adhesión y reconocimiento del "otro" em las figuras del margen, y a la vez sello biológico o metafórico de las filiaciones. Para hablar del "cansancio", tomo de Deleuze la idea de formar un par con agotamiento, ya que los dos términos arman una ecuación que reúne y distancia, a la vez, sus significados. Ambos configuran una imagen adecuada de una sociedad que intenta recrear lazos comunitarios sin el patronazgo de los poderes y con la política acorralada por la vía contable: algo que puede traducirse aproximadamente como agotamiento del Estado, en paralelo con el cansancio generalizado de los ciudadanos" (AMADO, 2009, p. 217).
} 
cansaço e esgotamento, no seu último texto intitulado "O Esgotado"50 (2010). Para Amado (2009), os personagens de Lucrecia Martel, mais do que cansados, estão sob as circunstâncias de uma anulação diante de todas as possibilidades, do esgotamento (p. 221). Embora possamos destacar que, talvez, as duas únicas personagens que ainda lidam com alguma possibilidade de realização seriam as adolescentes Momi (em, O Pântano) e Amália (em, A Menina Santa) e a personagem Verônica (A Mulher sem Cabeça) que passam o longo do filme em dúvida para decidir esquecer o acontecimento acidental para retomar a vida. Com uma análise sobre a reiteração das posições corporais horizontais mostradas nas camas (figuras 30 à 41), a autora questiona sobre a possibilidade da cineasta ter revelado uma intimidade atravessada pelo social "como lugar da psicologia, das obsessões, do erotismo, da visita do fantasmal e por isso mesmo, do terror"51 (idem, ibidem, p. 220).

Nos filmes de Martel, os corpos femininos de Mecha, Tali, Isabel, Vero, Momi $(O$ Pântano), Helena, Amália, José (A Menina Santa) e Veronica (A Mulher Sem Cabeça) estariam em evidência, pois são elas que se deixam restar sobre camas que se assemelham a

\footnotetext{
${ }^{50}$ Neste livro, Deleuze diferencia o "cansado como aquele que apenas esgotou a realização, enquanto o esgotado esgota todo o possível", ou seja, o cansado não pode mais realizar a mínima possibilidade (objetiva), não dispõe de mais nenhuma possibilidade (subjetiva), porém a realização do possível procede sempre por exclusão supondo preferências e objetivos que variam. Neste sentido, são essas variações, preferências e disjunções exclusivas que provocam o cansaço. Já o esgotamento acontece sob a conjunção das variáveis de uma situação com a condição de renunciar a qualquer ordem de preferência e objetivos, anulando a significação. $\mathrm{O}$ esgotado não está dentro da ordem da passividade - como é o caso do cansaço - "está em atividade, mas para nada". Deleuze utiliza essa diferenciação para analisar as obras de Samuel Beckett relacionando o "sentar" como ação do esgotado que não quer retomar a energia do corpo, mas permanece - $\mathrm{o}$ autor utiliza a figura daquele que senta e encosta a cabeça na mesa -, e o "deitar" como ação do cansado que ainda conta com a possibilidade de restabelecer a energia do corpo. "Os personagens de Beckett brincam com o possível, sem realizá-lo", ou seja, segundo a análise de Deleuze, nas obras de Beckett os personagens vão percorrer séries exaustivas e esgotantes de circunstâncias que nunca são realizadas. Ver DELEUZE, Gilles. "O esgotado" (L'épuisé). Tradução para o português de Lilith C. Woolf e Virginia Lobo. Zahar, 2010.
}

51 Tradução minha. "Remitem a un suplemento de historia personal, ya sea por vía de los cuerpos representados o implícitos en las composiciones - o como lugar mismo de la psicologia, das obsessiones, del erotismo, de la visita de lo fantasmal y por eso mismo, del terror. Situadas entre lo visible y lo invisible con la mediación de los cuerpos, las camas se transforman en una sinécdoque de lo social, o de la intimidade atravessada por lo social. El agotamiento - ya no el cansancio - encontró, por su parte, una variante familiar en el cine La Ciénaga (Lucrecia Martel, 2001), un filme en que las camas atraviesan la puesta em escena como contraparte de personajes cuya extenuación no parece reconecer diferencias generacionales." (AMADO, 2007, p. 220) 
$\operatorname{tumbas}^{52}$, de tão escuras e misteriosas. Amado resgata algumas modalidades do tempo do livro de Julia Kristeva "Sentido y sinsentido de la rebelión” (1999) para abordar a corporalidade feminina em relação as acepções de revolta e mistério. Nas imagens abaixo, podemos constatar uma variação entre as posições horizontais reiteradas nos três filmes da cineasta onde os personagens revelam uma intimidade subversiva através de uma corporalidade inerte.
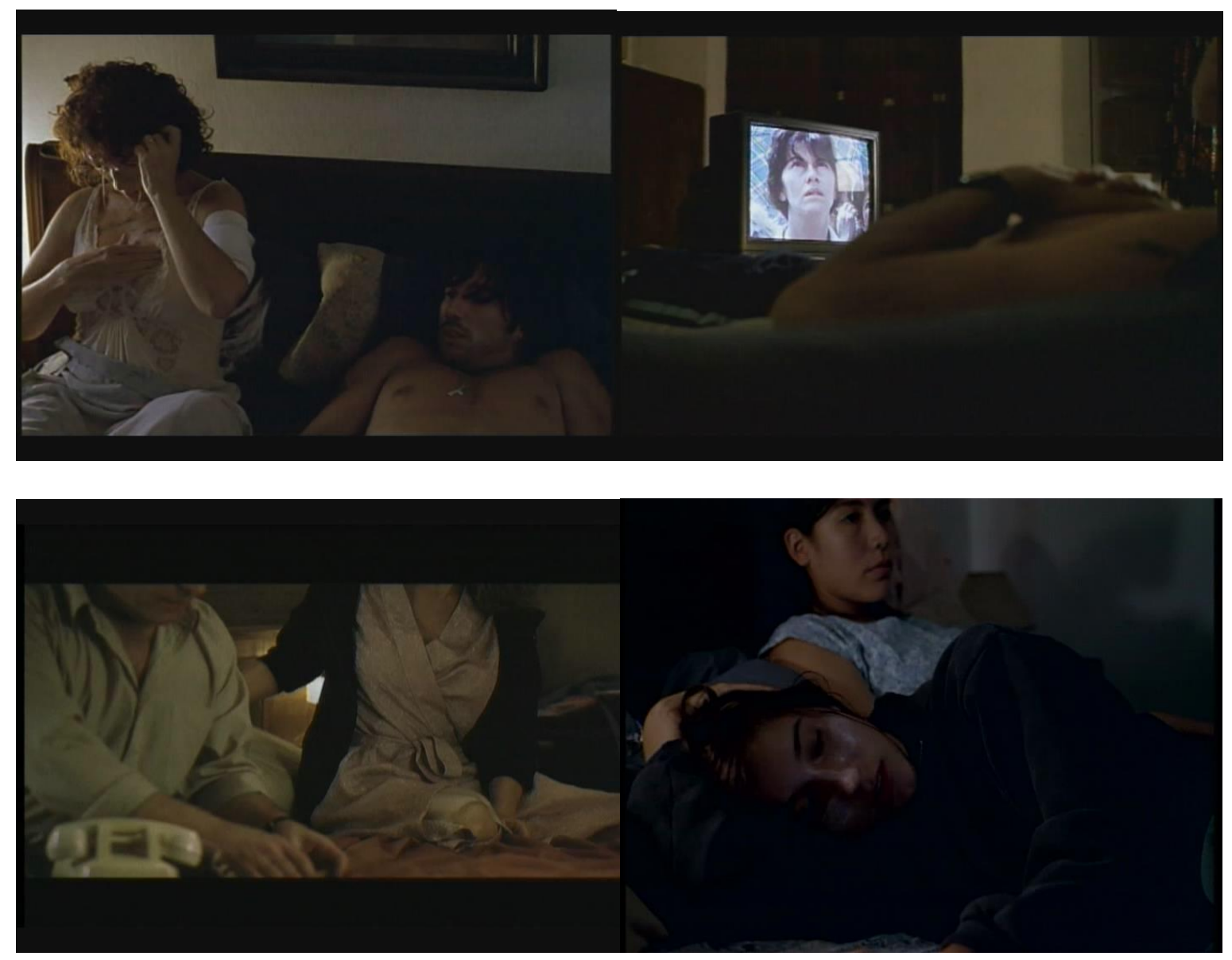

Figuras 30, 31, 32, 33 .

52 As "camas tumbas" é uma referência ao capítulo "Cansacio y Precipitacion", no qual Amado desenvolve a relação entre as imagens horizontais da cama e a chegada da morte com a queda - elemento vertical presente no acidente de Mecha e de Luchi. Outra relação é também desenvolvida pela autora a partir da presença da crença à virgem, no alto da caixa d'água. Porém, podem-se apontar outros exemplos em relação à mesma ideia presentes também no filme A Menina Santa, no qual a personagem Amália (Maria Alché) aparece em uma cena dentro do quarto do hotel onde sua mãe, Helena (Mercedez Morán), está dormindo na cama e comenta - Esta habitación parece una tumba. Em outra cena, é a vez de Helena mencionar ao sair da piscina para Amália - No estas morta?. Neste último exemplo, a palavra morta aparece com sinônimo de cansaço, no sentido de um esgotamento físico após experimentarem o banho quente da piscina. 


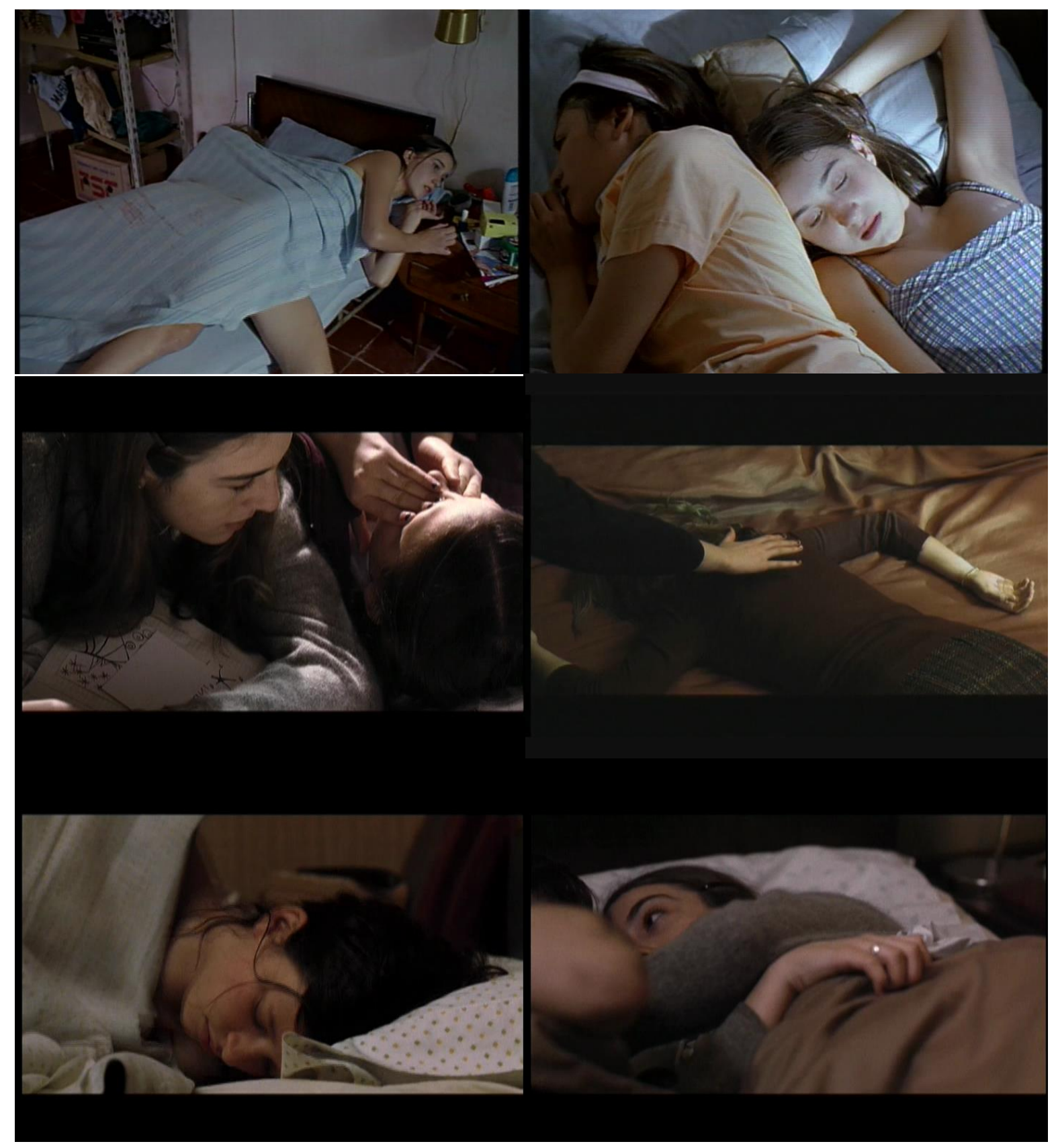

Figuras 34, 35, 36, 37, 38, 39. 


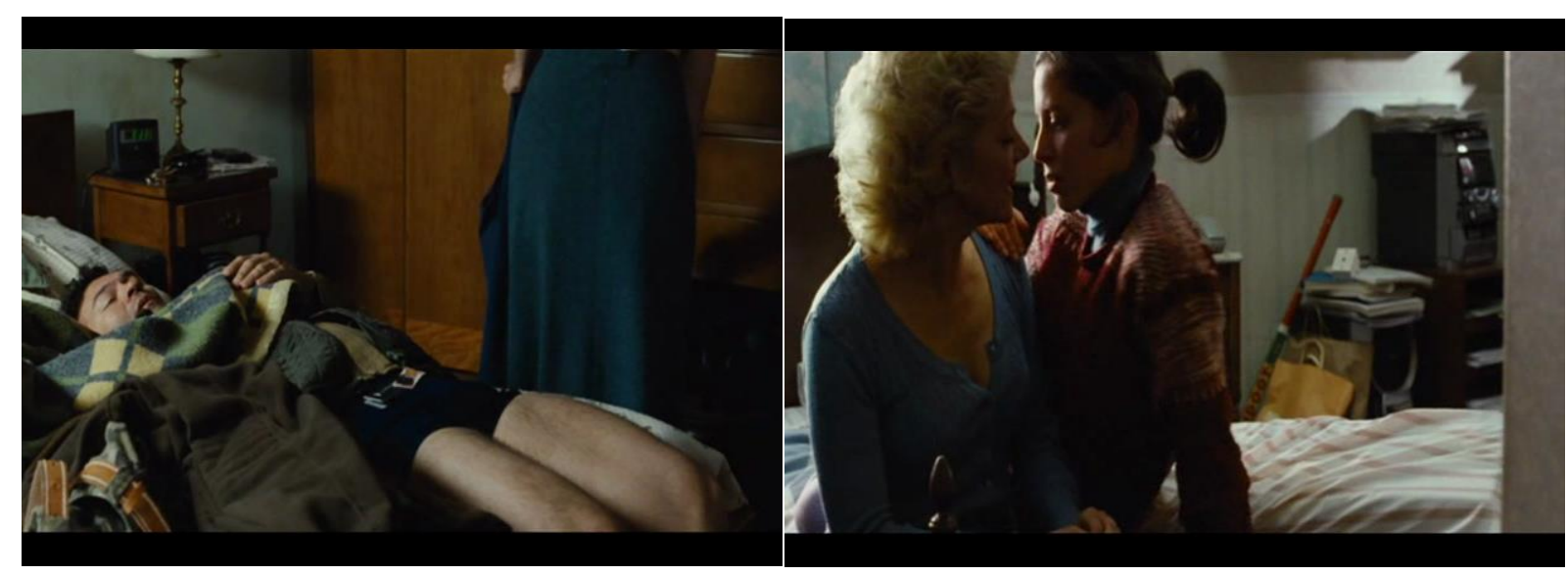

Figura 40.

Figura 41.

Interessamo-nos aqui pela estranheza da representação de uma temporalidade e um espaço subjetivo dos personagens. Nos filmes de Lucrecia Martel, é em meio ao diálogo impossível das falas sobrepostas que acontecem entre um personagem que não se destina ao diálogo com o outro exterior a si mesmo, ou aquele que dá uma resposta rápida apenas para livrar-se da situação, que podemos ver manifesto a busca por um tempo perdido do inconsciente. As experiências retratadas estão concentradas na exploração de espaços subjetivos reveladores de diferentes aproximações com o tempo interno e externo dos personagens: os diálogos ensimesmados, a algazarra do ambiente que destaca a figura corporal daquele que permanece quieto, os silêncios dos personagens frente à câmera ou mesmo a estranheza quando ouvimos vozes, mas não vemos a boca se mover escondida atrás de algum obstáculo. Nos filmes de Lucrecia Martel e de outros cineastas do Nuevo cine argentino, temos a representação de experiências íntimas, voltadas a diferentes dramas da subjetividade e a diferentes aproximações com o tempo.

Através do resgate das obras de Julia Kristeva, Amado nos propõe uma análise das figuras da subjetividade no cinema argentino como matrizes de sentido que nos permitem analisar, tanto no nível da cultura como no nível do sujeito, um vínculo entre a desordem de uma crise e a sua representação nas artes. Para Kristeva (1999), estas figuras da subjetividade 
presentes na cultura se apresentam, particularmente, como "formas artísticas insólitas, feias

[...] Elas também se manifestam em um minimalismo rudimentario ou, pelo contrário, muito refinado",53 (KRISTEVA, 1999, p. 23). Trata-se de obras presentes nas artes visuais, na literatura e em outras manifestações artísticas que se encontram disseminadas no mundo através da ênfase de um formalismo minimalista. Nestas obras através do uso do silêncio, da rarefação e da repetição, as formas insólitas e feias são ressaltadas a partir de fenômenos sensoriais ou da estranheza de representação dos espaços e de temporalidades subjetivas. Segundo Kristeva (1999), os espaços e tempos subjetivos foram exaustivamente discutidos nas obras literárias e estudos de Freud, Roland Barthes e Sartre. Ao longo do livro "Sentido y Sinsentido de la rebeldia", Kristeva detém-se sobre a obra destes autores, porém inicia sua pesquisa retomando uma experiência mais atual, relembrando a ocasião na qual assistiu na Bienal de Veneza em 1993 as formas minimalistas das instalações de Robert Wilson e Hans Hecke $^{54}$.

\footnotetext{
${ }^{53}$ Tradução minha. "formas artísticas insólitas, "feas" [...] Pero también sucede que ellos se complazcan em un minimalismo rudimentario o, por el contrario, refinado" (KRISTEVA, 1999, p. 23)

54 "Las obras expuestas en esta Bienal no se situaban en la misma historia de lo Bello. Podíamos advertir, por cierto, la perfección y la maestría técnica de la norteamericana Louise Bourgeois, que transforma el trauma en fetiche, o los cráneos del escultor francés Reynaud que aligera con mucha gracia o de manera cartesiana la obsesión de la muerte; pero también se encontraba allí algo que me pareció como el emblema de esta Bienal e incluso, tal vez, del arte contemporáneo: efectivamente, dos objetos me impactaron de manera particular, pues me parece que, a pesar de los artista que los produjeton, se encontran cargados de un sentido simbólico. Se tratan de dos instalaciones o, si se quiere, de dos esculturas, una del alemán Hans Hacke, la otra del norteamericano Robert Wilson, que figuran de manera diferente el desmoronamiento de los fundamentos. La insólita instalación de Hans Hacke nos hace avanzar sobre un suelo que se sustrae, que se destruye; los fundamentos se derriban. Em cuanto al suelo de Bob Wilson, éste no se desgasta sino que se hunde, va siendo engullido. Un campo de ruinas por un lado, por otro un suelo que se empanatana, que se desploma. El público queda fascinado, conmovido por estos volúmenes, como si em aquellos dos espacios uma interrogación muy estremecedora se hubiera apoderado del cuerpo. Pérdida de una certeza, pérdida de la memoria. Pérdida política, moral, estética? [...] La instalación de Bob Wilson llevaba por nombre Memory Lost. Em ella volví a encontrar aquel acceso a lo arcaico que Proust simboliza magistralmente con la Recherche. Uno ingressaba a un gran hall, retiraba sus zapatos y caminaba sobre uma espuma donde se hundía un poco, donde tenía la impresión de perder pie. Un proyetor iluminaba un busto de hombre con la cabeza rapada. Le entregaban a uno un texto. Era una experiencia sensorial de la luz, del tacto, así como del sonido. Uno vivenciaba una historia que le contaba que algún pueblo extraño acostumbraba rapar la cabeza de aquellos que se deseaba convertir em los esclavos, antes de exponerlos al sol. De este modo, sus cabellos crecían hacia adentro y no hacia afuera del cráneo, y perdían la memoria. Al contarnos esta fábula por medio de diversas e intensas señales Bob Wilson nos invitaba a experimentar este peligro de perder la memoria que el orden normalizador hace pesar sobre nosostros" . Ver: KRISTEVA, Julia. Sentido y Sinsentido de la rebeldía: literatura y psicoanálisis. Tradução para o espanhol por Guadalupe Santa Cruz, 1999. p. 24 e 35.
} 
Ao longo das últimas reflexões, apresentamos sobre os filmes de Lucrecia Martel um “espaço indiscernível” que se insere através de um jogo posto entre a visão e a escuta (OUBINA, 2007) e um fuera-del-tiempo de alcance simbólico que retoma as figuras de uma queda e da precipitação de ruínas através de um jogo visual e narrativo (AMADO, 2009; AGUILAR, 2010). Nestes dois jogos, podemos constatar que a indiscernibilidade da imagem e a escuta textural dos sons fora de campo foram ressaltadas pela criação de uma relação de estranheza familiar aos espectadores e personagens dos filmes analisados. Ao ouvir sons inaudíveis e invisíveis, os personagens destas histórias compartilham uma escuta interiorizada e um espaço subjetivo, onde as imagens se mantêm fora da nossa visualidade, apenas precipitadas e imaginadas. Contudo, mesmo habitando lugares indiscerníveis e plasticamente ambíguos os sons e as imagens estão dotados de um sentido simbólico nestas narrativas. A partir deste recorte, enfatizamos a representação de fenômenos sensoriais, das emoções e temporalidades diversas através da repetição dos sons, da repetição de enquadramentos e de uma gestualidade ritualizada do cotidiano dos personagens.

Através da repetição e da variação dos sentidos em relação aos sons, às imagens e as lendas orais contadas pelos personagens tecemos ideias sobre as figuras do esquecimento, da fadiga, do cansaço e outras formas inertes que dão acesso a uma temporalidade interna e externa. Contudo, nos atemos a um último exemplo de análise fílmica para demonstrar como os sons podem transitar pelas cenas transbordando dimensões entre a realidade e o espaço subjetivo dos personagens e espectadores. Sons que foram acusmatizados e repetidos se inserem na narrativa novamente flutuando entre as funções topológico e espaciais (que conferem presença à imagem) para depois revelarem um ponto de escuta subjetivo dos personagens, pontuando uma emoção sentida pela personagem Amália.

Em A Menina Santa, a interiorização da escuta acontece no decorrer da narrativa 
através de alterações de sentidos de um mesmo som que transita entre a concretude do espaço físico e geográfico para representar alguma angústia, confusão ou crise vocacional experimentada pela personagem.

\subsection{A interiorização da escuta: ponto de escuta subjetivo e atmosferas deliquescentes} em A Menina Santa

Em "Crisis and Capitalism in Contemporary Argentine Cinema", Joana Page identifica que A Menina Santa encontra-se precisamente localizada na intersecção desta questão, lugar onde o feio encontra-se indefinido - misturado - em relação ao belo e ao sagrado. Segundo Page (2009), Martel promove uma dinâmica onde as inquietantes descobertas sexuais das adolescentes revelam "uma experiência tão mística quando mundana 55" (PAGE, 2009, p. 190).

Numa das cenas do filme A Menina Santa (2004), uma das garotas, amiga de Jose (Julieta Zylberberg) e Amália (Maria Alché) do grupo de estudos católicos, aparece confusa com os sinais do chamado de Deus é repreendida por Inês (Mía Maestro), a professora de catequese do grupo, com o seguinte comentário: "no creo que alguien pueda confundirse algo feo com algo lindo, algo que te llena de felicidade com algo horripilante, ¿no?’. A existência de um paralelo entre a experiência sagrada da vocação religiosa e o despertar sexual do corpo provocaria várias sensações nas adolescentes que são representadas a partir de uma ironia cômica, da ingenuidade e da ameaça.

\footnotetext{
${ }^{55}$ Tradução minha. "Martel, however, is interested precisely in those areas of experience that are difficult to define as either "feo" (ugly) or "lindo" (beautiful): the disquieting discoveries of sexual awakening, an experience at once so mystical and so mundane". Ver: PAGE, Joana. "Crisis and Capitalism in Contemporary Argentine Cinema. Duke University Press, 2009.
} 
No capítulo "Politics of Private Space", Page aponta que a ambiguidade nestas experiências é sublinhada através das interpretações anárquicas e profanas das adolescentes que ameaçam o sentido da natureza da salvação e da vocação enfatizada por Inês. Os significados tornam-se subversivos com a confusão dos sinais da "voz de Deus" e Amália junto às outras garotas escutam, sentem, mas nunca vêem e tocam estes sinais. Dentro da confusão acerca dos ensinamentos sagrados, a personagem de Amália encontra justificativas para sua missão divina e inicia uma perseguição à Dr. Jano (Carlos Belloso).

Sob esta perspectiva, podemos apontar que os corpos representados nos filmes de Lucrecia Martel mantém-se na busca desse entrançamento entre carne e espírito. Numa recusa em narrar nos seus filmes uma totalidade espaço-temporal, a cineasta cria um espaço indiscernível nos quais os espectadores observam os personagens através de ritmos corporais em inquietação. Através do ofuscamento de imagens, no qual as retinas dos seus personagens encontram-se fascinadas pelo horror de ter tudo à vista, a cineasta insere a corporalidade e o desejo nos seus filmes. Na condição de estrangeiros de "si-mesmos", a noção de espaço parece mudar a cada instante - sempre indefinível -, e os personagens aparecem abandonados sob uma sensação de desordem orgânica.

Em A Menina Santa podemos constatar o uso dos sons do ambiente cotidiano dos personagens para enfatizar sensações epidérmicas, as quais analisadas a partir de intenções, olhares e movimentos dos personagens se apresentam atuantes na instância subjetiva do pensamento. Numa das cenas do início do filme, logo após Amália ter sido molestada por Dr. Jano, pode-se perceber a criação de uma constante tensão no ambiente deliquescente através dos sons do entorno da piscina. Estes rumores de orações e sons transformam-se em escrínios sonoros, transitando entre a função topológico-espacial (CHION, 2011) para representação de um ponto de escuta subjetivo da protagonista. Segundo Chion, a natureza omnidirecional do som e da escuta quase nunca nos permitirá definir exatamente pontos de escuta no cinema. 
Contudo, em casos particulares, a determinação de um eixo visto por um personagem e o uso de sons de fraco alcance pode nos ajudar a definir pontos de escutas subjetivos, "a partir da audição desses sons, ou de indícios sonoros de proximidade (respiração na voz), o espectador pode então situar o ponto de escuta como sendo o de um personagem que vê em cena" (CHION, 2011, p. 75)

Nesta cena, Amália está à beira da piscina deitada de bruços (de costas para a câmera, figura 43) e observa um homem nadar. Espiamos à distância e juntos da personagem o nadador que entra e sai do quadro, sem vermos a sua imagem nítida pela falta de profundidade do plano. De um ponto de vista próximo ao rosto de Amália, observamos o movimento da sua respiração. O plano longo, não mostra o espaço ao redor e nos detemos muito mais na direção do olhar da protagonista. Quase tudo aparece imóvel, a não ser pelos sons, em primeiríssimo plano sonoro, da movimentação da água e de respirações que nos indicam a existência de mais pessoas naquele lugar do que vemos na imagem. A indiscernibilidade do espaço é quebrada alguns segundos depois, quando ouvimos uma voz masculina distante e marcada pela presença de uma reverberação que grita: 34 graus! O nadador vira-se (reconhecemos Dr. Jano, interpretado pelo ator Carlos Belloso) e repentinamente movimenta-se em direção ao olhar de Amália. Simultaneamente, Amália esconde o rosto e vira-se de frente para câmera (figura 43). Ouvimos uma voz feminina, que também surge do espaço fora-de-campo e diz - O quê?

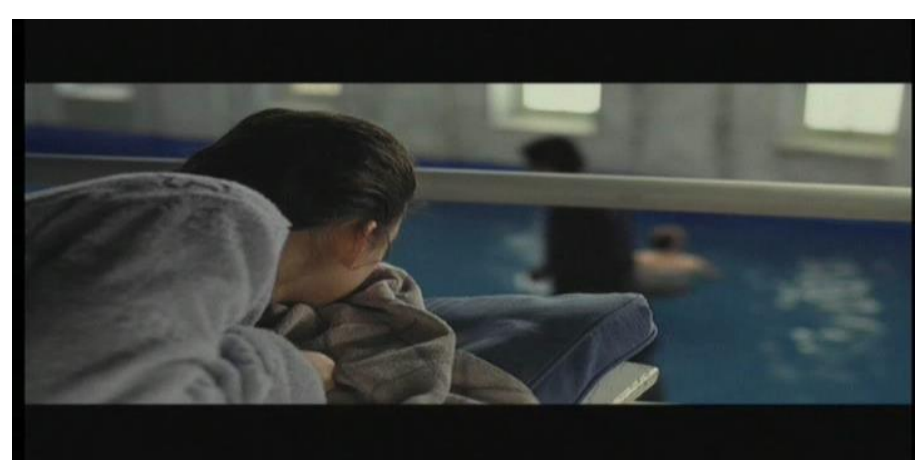

Figura 42. 


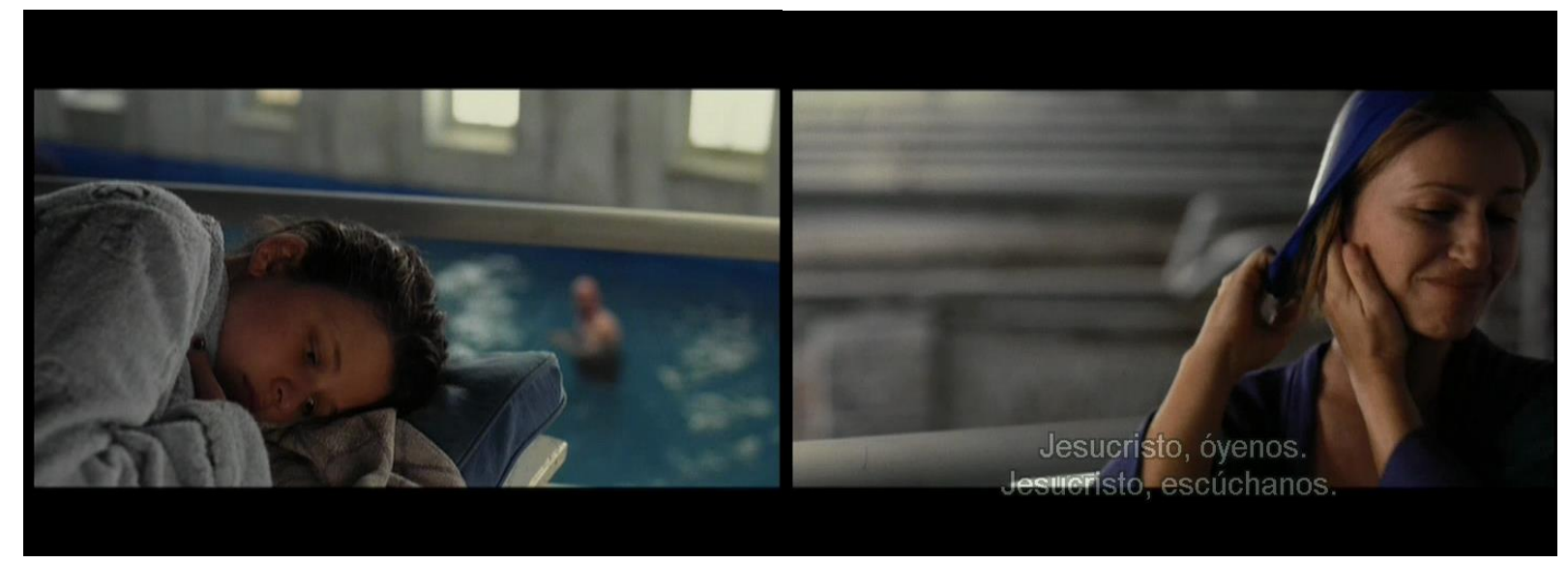

Figura 43,44, 45 e 46.
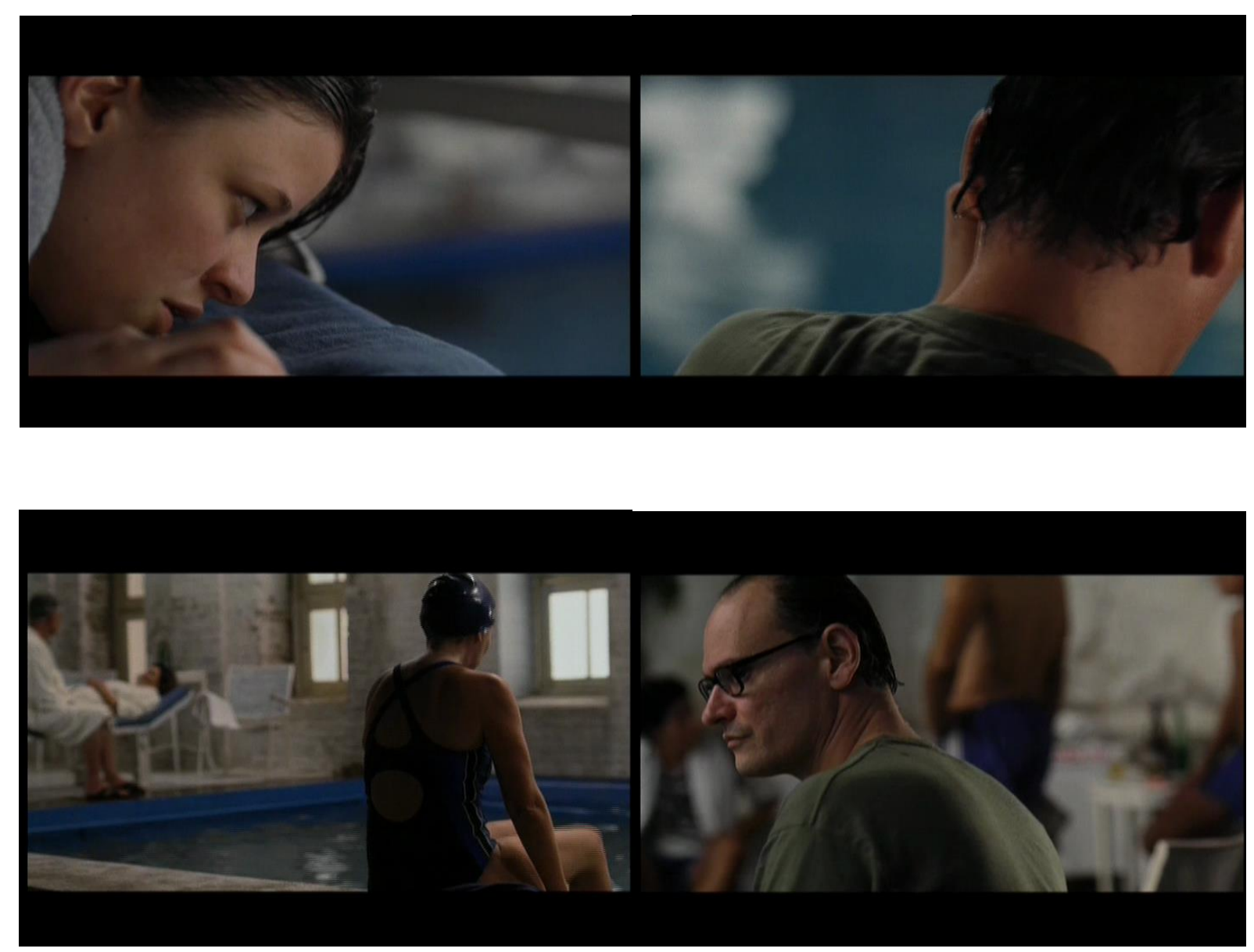

Figura 47.

Figura 48. 


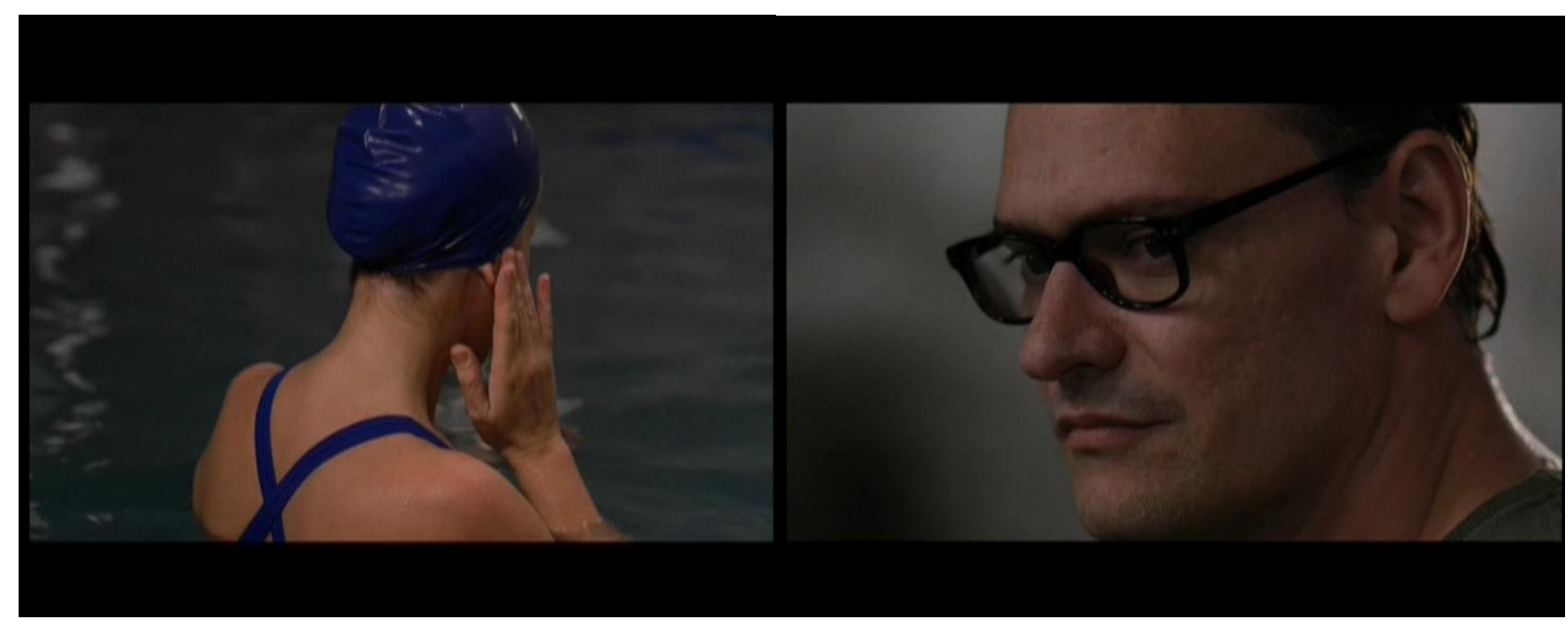

Figura 49.

Figura 50.

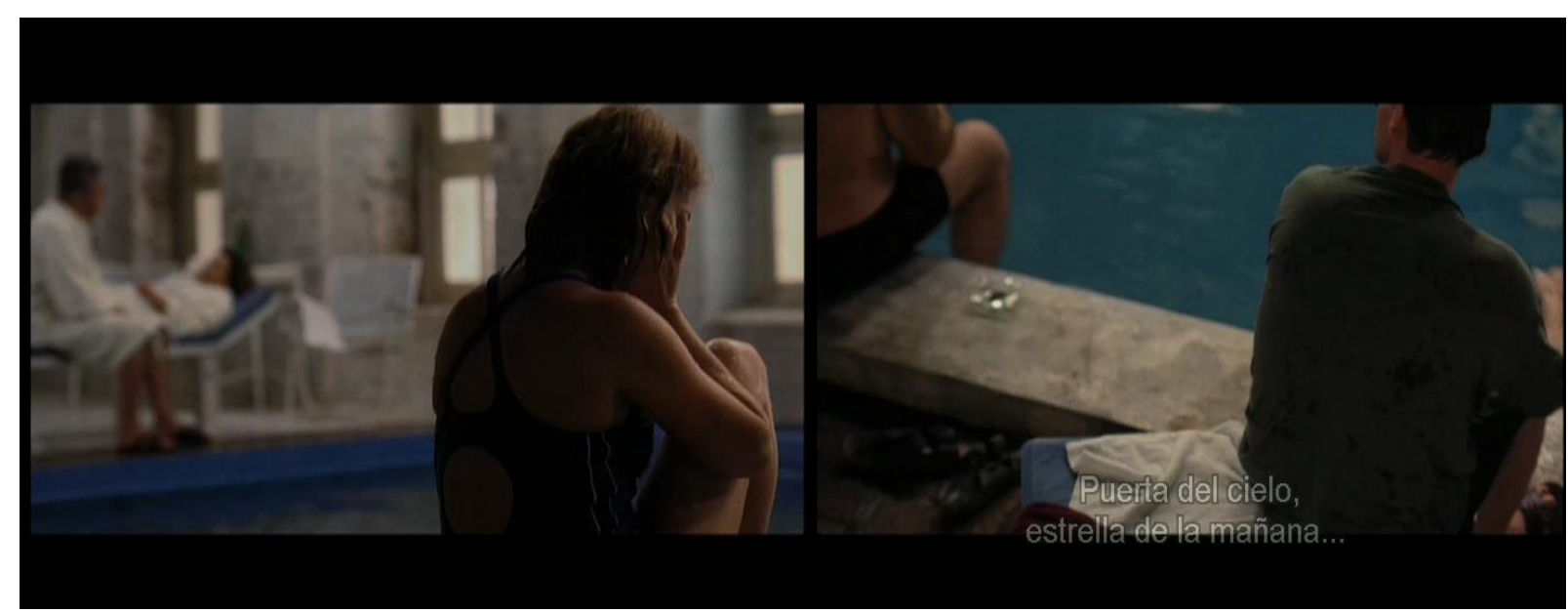

Figura 51.

Figura 52.

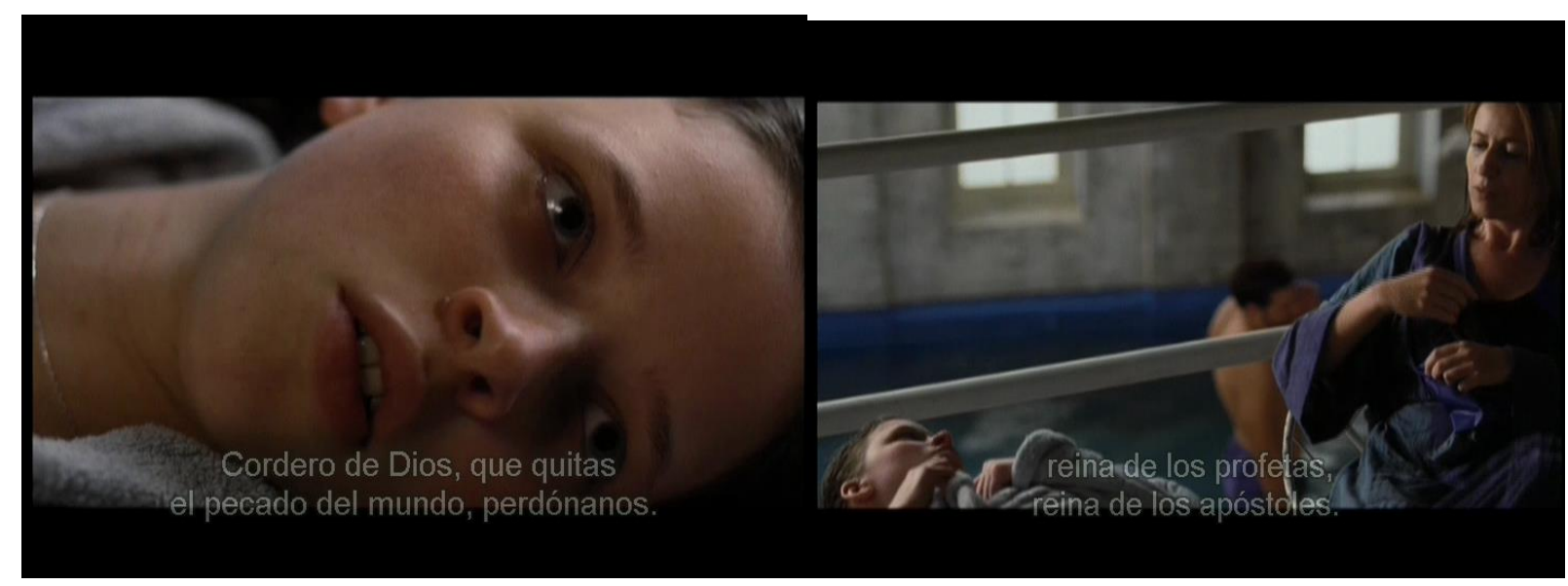

Figura 53.

Figura 54. 


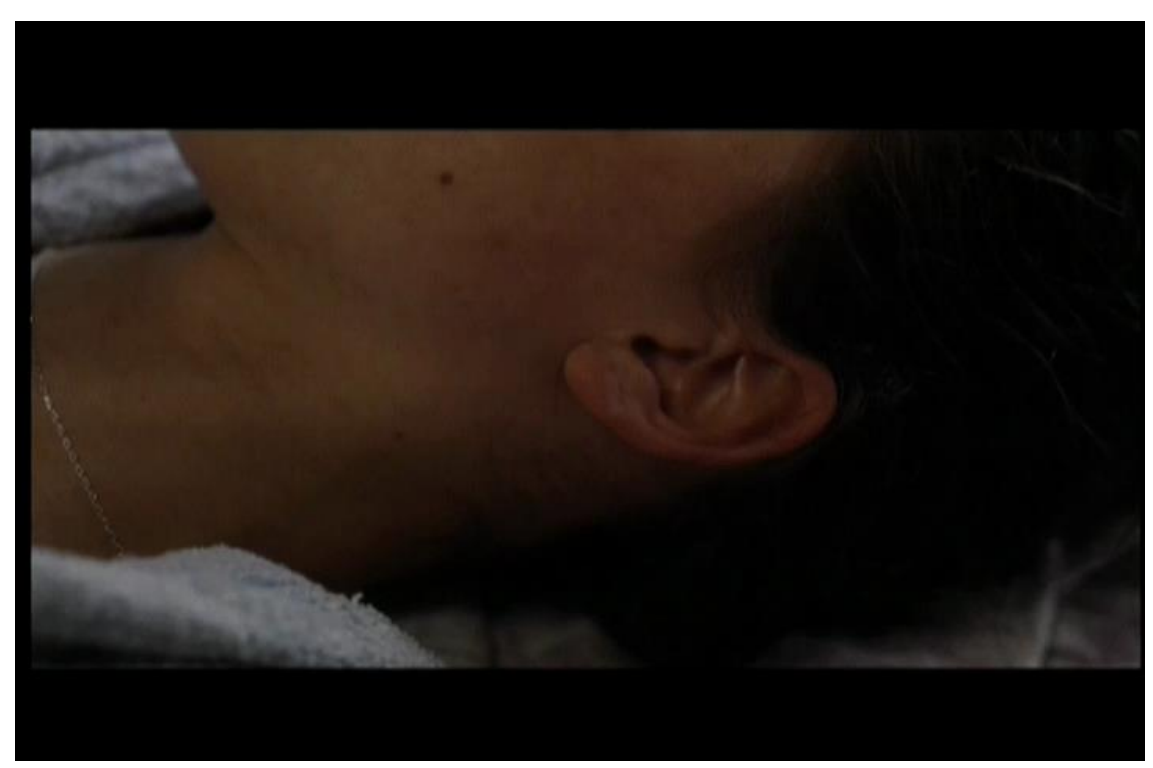

Figura 55.

No primeiro plano descrito desta cena, a falta de profundidade de campo apresenta um espaço indiscernível, onde o foco parece estar centrado numa corporalidade transitória da adolescente. A visão da cena é ocultada em detrimento de representações não-verbais, das sensações e dos afetos da personagem que acederá à linguagem das palavras apenas para interromper a palavra do outro. Neste caso, da outra, na condição de uma pulsão oral estruturada dirigida em relação à mãe - a voz feminina que diz $O$ quê? A filha, Amália, sussura que "no dice nada" e refugia-se dentro do murmúrio de uma oração, distanciando-se da realidade. Em oposição à visualização do espaço, Amália abandona o olhar para recolherse numa escuta interiorizada ${ }^{56}$ (AGUILAR, 2010, p.102). Neste momento, há uma mudança

\footnotetext{
${ }^{56}$ O crítico argentino Gonzalo Aguilar na análise sobre A Menina Santa em "Otros Mundos: un ensayo sobre el nuevo cine argentino" (2010) faz uma associação entre escuta e recolhimento em contraposição a visualidade e a sua exterioridade. Para o autor, "mientras los sonidos tienen que ver com la presencia, lo interior, el recogimiento, la imagen impone la distancia, la exterioridad, la distinción de los elementos. La visualidad impone una relación de poder y dominio diferente a la de la audición". Em referência a Roland Barthes, Aguilar trabalha a idéia de que na Idade Média "la primacía del oído, muito fuerte todavia en el siglo XVI, estaba teológicamente avalada: la Iglesia funda su autoridade em la palabra, la fe es audición: auditum verbi Dei, id est fidem; sólo el oído, dice Lutero, es el órgano cristiano". (BARTHES apud AGUILAR, 2010, p. 102). Conforme Aguilar, Lucrecia Martel teria utilizado essa primazia do ouvido no cristianismo para desenvolver uma história onde a personagem principal transita entre as pulsões corporais e a fé católica.
} 
na perspectiva dos sons ambientes pontuada pela mudança do ponto de vista da imagem, que mostra um plano um pouco mais aberto revelando o ambiente da piscina com a entrada de Helena (figura 47).

Até este momento, ouvia-se a reverberação das vozes mais distantes e um som da água hiper-amplificado, em primeiríssimo plano sonoro. Neste ambiente sonoro deliquescente temos sobreposto lentamente um som áspero, como o de um ambiente à vácuo sendo preenchido pelo ar. Gradativamente, ouvimos o chilrear das cigarras em movimento crescente para se transformarem em uma floresta sonora, também localizada muito próxima dos nossos ouvidos (sem a reverberação do espaço). Os ruídos das cigarras entram e saem concomitantes as mudanças do plano imagético como se pontuassem o ponto de escuta subjetivo da personagem, indicando uma transição de sensações corporais em Amália. Os sentidos da tatilidade e da audição são apresentados, antes de tudo, para pontuar uma perturbação no ambiente, momento de tensão onde o olhar de Amália reconhece o olhar de Dr. Jano para o corpo da sua mãe (figura 48).

A voz fora de campo que já foi reconhecida como sendo de Helena (após a abertura do plano imagético, pode-se constatar que a mãe encontra-se sentada em uma cadeira de descanso ao lado) insiste em conversar com Amália, mas a garota a ignora mantendo uma oração sussurrada (Figura 44). Helena entra na piscina, segura o ouvido com a mão como se estivesse entupido. O plano mais fechado da imagem destaca o ouvido de Helena (figura 49). Neste momento, todo o espaço sonoro da floresta de cigarras é suprimido junto às vozes dos personagens. Ouvimos somente os sons da água da piscina e uma respiração curta, sutil e pontual que acompanha o movimento de Helena dentro da piscina. Outro corte brusco e a mudança de ponto de vista mostra um close do rosto de Dr. Jano (figura 50), acompanhado de uma variação nos sons ambientes com a sobreposição do som áspero provocado pelo efeito sonoro de um espaço oco sendo preenchido de ar. No final desta cena, a variação dos sons e a 
mudança de ponto de vista (figura 52) voltam a representar o ponto de escuta de Amália.

O ponto de escuta representado nesta cena segue os personagens dentro do ambiente, com uma alternância entre os pontos de escuta de Helena, Amália e Dr. Jano, em sincronia com os cortes do plano imagético que acompanham os pontos de vista destes personagens. A cada transição de pontos de escuta, as imagens mostram o close do rosto dos personagens, enfatizando os recortes das orelhas. Nestes filmes, a gestualidade, os rumores de respirações e os sussurros de vozes são usados nas funções topológico-espaciais para conferir um efeito de autenticação sensorial do espaço, identificando os sons a partir do espaço mostrado na imagem. Porém, ao transitarem entre os diferentes pontos de escuta, os sons do ambiente são subjetivados e utilizados com o propósito de adquirir uma função mais simbólica na narrativa. O que nos interessa nesta cena, é o destaque para o uso destes elementos sonoros e a pontuação da escuta relacionada ao desejo dos personagens. Helena é a única personagem deste triângulo de orelhas que não tem um ponto de vista marcado, sua aparição ao longo do filme é pontuada como a "mulher que se subordina aos olhares e saberes do homem",57 (AGUILAR, 2010, p. 105). O crítico argentino Gonzalo Aguilar (2010), em sua análise sobre este filme pontua que a personagem de Mercedes Morán sempre aparece submetida a uma lógica visual e masculina de dominação, ao contrário de Amália que se refugia na potencialidade dos outros sentidos, como o tato e a escuta (idem, ibidem, p. 104).

Em A Menina Santa as sensações táteis e auditivas deslizam entre camadas de motivos e imagens. Numa das primeiras cenas onde percebemos uma perturbação em relação aos sons fora de campo, ouvem-se sons de um theremin que chamam atenção das adolescentes numa sala. Ao longo do filme, o som de origem misteriosa deste instrumento chama a atenção de espectadores na rua, dentre eles, Amália. Enquanto Amália olha fascinada o instrumento, o

57 Tradução minha. "mujer que se subordina a la mirada y al saber del otro, um hombre" (AGUILAR, 2010, p.105). 
médico Dr. Jano chega por trás tocando o corpo da adolescente. Mais adiante, a mesma ação é repetida entre Dr. Jano e Amália e o instrumento torna-se motivo que narra sonoramente o conflito da protagonista entre sua crença e a sedução de um amor carnal (AGUILAR, 2010; PAGE, 2009). Porém, como apontado por Aguilar (2010) Amália, ao contrário de Helena, não se entrega ao domínio visual de Dr. Jano, seguindo os sons misteriosos que podem explicar a sua verdadeira vocação. Desde os primeiros momentos do filme, os sons simbolizam o mistério do mundo, evocando uma entidade divina que promoverá sinais sonoros para salvação cristã dos personagens. Escutam-se estrondos de um homem nú que cai do alto de um prédio, microfonias, ruídos do theremin e outros sons que tentam simbolizar uma voz sobrenatural e inaudível do plano divino. A voz inaudível de algo divino e sobrenatural permeia a narrativa deste filme como um personagem acusmático cuja posição em relação à imagem se situa dentro de uma lógica da ambiguidade - nem dentro e nem fora da imagem está implicado nos acontecimentos, provocando perturbações e dúvidas nas adolescentes. Outro som que provoca perturbação, os acúfenos inaudíveis sentidos por Helena (figura 49) que sofre da Síndrome de Manière - tornam-se motivos na narrativa, convertendo-se em caso clínico para representação de um diagnóstico no final do filme. Dr. Jano, especialista na doença, aproveita o motivo ruidoso para investir mais flertes à Helena.

Em “Crisis and Capitalism in Contemporary Argentine Cinema”, Joana Page (2009) observa que a falta de fé torna-se um motivo presente de diversas maneiras nos filmes de Lucrecia Martel $^{58}$. A teórica refere-se à ênfase da cineasta em retratar nos seus filmes experiências corporais de personagens que tragicamente abandonam qualquer iniciativa que os possa livrar de seu egoísmo existencial em busca de uma transcendência. Trata-se da revelação de um espaço de intimidade através da percepção de experiências no corpo dos

\footnotetext{
$58 \quad$ "This crisis of religion as a signifying estructure that could lend a degree of protection against the banality and futility of individual lives reflects a more general collapse of distinctions in these films between the private and the public" (PAGE, 2009, p. 191).
} 
personagens marcadas pela pressão do calor, dores, febres, infecções, corpos que tocam outros corpos e corpos que submergidos em águas. Segundo Page (2009), tais experiências íntimas revelariam um corpo insular, semelhante a uma ilha isolada provocam um afastamento da convivência em sociedade ${ }^{59}$. A crise da fé não traz libertação ao corpo, ao contrário, os encerra dentro de uma representação de possibilidades frustradas: como a impossibilidade da realização do desejo carnal entre Helena e Jano, entre Jano e Amália (A Menina Santa), e mesmo em $O$ Pântano, entre os personagens de Momi e Isabel ou José e Verô.

Contudo, na representação do desejo da "Menina Santa" - Amália - as cenas de beijos reveladas entre a personagem e sua prima Josefina e, mesmo entre ela e Dr. Jano parecem não se incluir nesta lógica "cerrada" de possibilidades.

\section{CONCLUSÃO}

No início do capítulo "Falar não é ver”, Maurice Blanchot (2005) nos lembra que falar, não é ver. O texto do autor em forma de uma conversa mostra que falar se aproxima do significado de buscar, de tornear, de dar à volta, rodear. A conversação descrita pelo autor mostra os caminhos para tornear o movimento melódico, fazendo-o girar sem a ideia de uma finalidade, de um sentido. A conversa é infinita, pois implica no desejo de usar as palavras até que os sentidos se evacuem, deslizem. Blanchot nos apresenta uma espécie de fala errante, escrita ficcional que atua num espaço vertiginoso. Longe do esclarecimento das coisas, as palavras carregariam consigo a proximidade de uma interrogação. Errar seria voltar e retornar,

59 "The alienation of her characters is traced with a particular anguish: here is no straightforwardly postmodern celebration of individual liberation of the collapse of tradicional bastions of authority and morality" (idem, ibidem, 191). 
abandonar-se à magia de um desvio. E a busca nas escritas ficcionais seria, portanto, uma espécie de erro, nos levando à suspensão das palavras. Ao contrário, vê-las impõe distância, uma decisão separadora, o poder de não estar em contato e "quando o que é visto impõe-se ao olhar, como se este fosse capturado, tocado, posto em contato com as aparências? O olhar é atraído e o fascínio é a paixão da imagem" (2005, p. 22-24).

Neste trecho, Maurice Blanchot parece nos dizer que os enunciados jamais fazem ver, assim como a visibilidade não se torna algo legível. O meu estudo sobre os filmes de Lucrecia Martel parece-me dizer algo semelhante, como se a idéia dos seus enunciados não abarcassem a visibilidade das coisas. Na frase final dita pela adolescente Momi, em O Pântano - no vi nada - confirmamos uma dissociação contínua entre a figura e o discurso. Este enunciado nunca conterá o visível. Embora, esse enunciado revele um paradoxo inevitável - a figura que vemos na tela se relaciona com o seu discurso a partir da fascinação do espectador em olhá-la. O gesto repetido, já visto em outra imagem, o arrastar de uma cadeira, submerge o espectador para dentro de uma imagem posterior, reforça a constante dissociação entre o som e a imagem, e entre imagem e enunciado. A imagem que vemos nos filmes de Lucrecia Martel, nos devolve um olhar interrogativo, desafiador e indecifrável.

Ao lembrar sobre este episódio de palavras interrogativas, as próprias palavras me conduziram a outra lembrança, uma entrevista dada por Pierre Schaeffer à pesquisadora Bernadete Zagonel (1990), aonde fala que o seu trabalho como inventor da música concreta foi um grande erro:

"Pierre Schaeffer: E devo dizer, sem falsa modéstia, que após anos e anos de experimentação, tive a sabedoria de reconhecer que este caminho não levava a nada, somente a construções sonoras, senão gratuitas, ao menos desobedientes a todas as regras de uma possível estética musical. 
Bernadete Zagonel: Costuma-se dizer que o senhor é o inventor da música concreta. Como o senhor vê essa questão após todos esses anos?

Pierre Schaeffer: Percebo isso como um velho pode perceber seus erros de juventude. Ele não pode negá-los, não é?

B.Z.: Erros? Por que o senhor considera isso um erro?

P.S.: Digo erros de juventude como se diz de um rapaz que fez besteiras.

B.Z.: Então, ter inventado essa música é ter feito besteira?

P.S.: Quer dizer, eu não gosto muito do termo "inventar uma música”, apesar de que, com efeito, os contemporâneos tomaram a coisa como uma invenção. Eu sustentei, durante muitos anos de fervor e de experimentação, que havia aí uma música possível, em todo caso, um continente sonoro, musical, a ser reconhecido. Então, não posso negar este caminho que segui durante muito tempo, mas o que é mais incrível é que este caminho seguido com assiduidade, com muita energia, pois eu tenho muita energia e sou "cabeçudo", não levava a nada. Sou então um dos contemporâneos que ousa dizer: trabalhei muito, mas isto não levou a lugar nenhum" ( ZAGONEL, 2005, p.287).

O trecho desta entrevista, publicada na revista Opus em 2005, me fez lembrar ainda do erro comentado pelo músico concreto como uma espécie de círculo percorrido que se abriu à inutilidade, no qual as coisas só adquirem sentido com a volta das mesmas coisas; sentido este que não nos leva a lugar nenhum. O trabalho de anos de experimentação perdeu o sentido para músico? Se o caminho era seguido com assiduidade e afinco, como pode Pierre Schaeffer ter se encaminhado para o nada? O nada mencionado na entrevista de Pierre Schaeffer é o mesmo comentado pela personagem Momi, no filme $O$ Pântano?

Neste caso, os dois sujeitos - o ficcional e o real - deslizam para um entre-lugar. Entrelugar produzido na nossa cultura pela fissura provocada entre aquilo que é mostrado e aquilo 
que é dito. A partir desta disjunção entre as figuras e os discursos ficcionais, apontamos uma relação audiovisual nos filmes de Lucrecia Martel que promovem formas indeterminadas, incertas. Habitando um espaço indiscernível, os filmes desta cineasta se mantêm longe de revelar um segredo. Não, os segredos nunca são revelados, apenas sugeridos, traços escorregadios que se encontram entre um lugar e outro da narrativa. A partir de acontecimentos indeterminados, um universo ficcional ambíguo é revelado. Assim, abordamos ao longo desta dissertação pequenas disjunções entre o som e a imagem, que foram apresentados como sintomas de um modo de produção capitalista esgotado. O excesso de ruídos e informações surge através do rompimento das ligações contínuas, causais dos sujeitos. Os ruídos tornaram-se modos de representação da escuta no mundo contemporâneo e no cinema contemporâneo de Lucrecia Martel.

Vimos no pensamento sonoro do ecologista acústico Murray Schafer (2001), que os meios eletroacústicos dissociaram o som da imagem da sua fonte sonora, o que provocou uma "paralisia auditiva" nos sujeitos, impotentes em conferir significação aos sons diante do excesso e da intensidade dos ruídos. Se, para Murray Schafer os ruídos eletroacústicos são compreendidos sob uma ótica negativa, para Pierre Schaeffer (1988) os ruídos, mesmo perigosos, são responsáveis pela abertura temporal do ouvido. Dão acesso a um mundo onde escuta-se mais os sons concretos do cotidiano e onde escuta-se de maneiras diversas, múltiplas. Para o músico concreto, os sons acusmáticos - destituídos da imagem da sua fonte sonora - podem dar acesso a um tipo de escuta que percebe as qualidades sonoras ao se distanciar dos sentidos semânticos, figurativo e causal do som. Assim, ao assistir os filmes de Lucrecia Martel nos deparamos com vários tipos de escutas e sentidos, nutridos pelo jogo paradoxal causado entre a significação do som e a perda da sua referencialidade.

A afirmação de Pierre Schaeffer de que não há nada a se buscar, novamente, intercepta os nossos caminhos, a ideia ingênua de afirmar que é possível fazer música só com ruídos ou 
de que os ruídos no cinema também podem construir belíssimas músicas. Não, não há esta possibilidade. Interrompidos, interceptados, os ruídos nestes filmes não foram usados para construir músicas, e nem as músicas foram usadas como músicas - talvez sim, como ruídos interceptadores de sentidos, quando são apresentados a desenrolar-se como se nada tivesse passado (CHION, 2011).

O meu erro, ainda nos levou a percorrer os caminhos suspensos, onde pequenos resquícios e escrínios sonoros parecem trazer a vida de volta às imagens, mesmo que ainda sim não consigamos conferir-lhe um sentido pleno. Ao longo deste estudo, os sons foram apresentados como provocadores de irrupções bruscas nas narrativas e elementos agrupados que criam micro-ritmos. Foram destacados ainda como reveladores de experiências de esquecimento, de fadiga e do cansaço. Figuras ficcionais presentes nos filmes de Lucrecia Martel. A representação da interiorização da escuta, do silêncio que concretiza pensamentos e emoções, nos deu acesso as experiências íntimas dos personagens. Um sussuro de Amália, os rumores de crianças brincando e correndo nos corredores d'A Menina Santa; os cochichos mostrados nos cantos e fundos da casa de Mecha, ruminações para si mesmo mostradas em imagem de diversos personagens estirados nas camas trazem possibilidades diversas de acesso aos espaços íntimos e subjetivos. Com o tempo e o espaço libertos da sua causalidade, os filmes de Lucrecia Martel parecem revelar um caminho de possibilidades que pode nos conduzir ao nada, àquilo que está inacessível e inabarcável pela representação cinematográfica. 


\section{REFERÊNCIAS BIBLIOGRÁFICAS -}

AGUILAR, Gonzalo. Otros Mundos: un ensayo sobre le nuevo cine argentino, 2 edição atualizada. Buenos Aires: Santiago Arcos Editor, 2010.

AMADO, Ana. La Imagen Justa: cine argentino y política (1980-2007). Buenos Aires: Colihue, 2009.

AUMONT, Jacques. O Cinema e a encenação. Tradução Pedro Elói Duarte. Saraiva, 2012.

BARTHES, Roland. Fragmentos de Um Discurso Amoroso. São Paulo: Martins Fontes, 14 edição, 2007.

BLANCHOT, Maurice. A Conversa Infinita: a palavra plural. São Paulo: Escuta, 2010.

. A Conversa Infinita 2: a experiência limite. São Paulo: Escuta, 2007.

O Livro por Vir. São Paulo: Martins Fontes, 2005.

BURCH, Noel. Práxis do Cinema. São Paulo: Perspectiva, 1992.

CAMPESATO, Lílian. Arte Sonora: Uma metamorfose das musas. 2007. 173f. Dissertação (Mestrado em Musicologia). Escola de Comunicação e Artes da Universidade de São Paulo. São Paulo, 2007.

CERTEAU, Michel. A Invenção do Cotidiano: Artes de fazer. Nova edição estabelecida e apresentada por Luce Giard. Tradução Ephraim Ferreira Alves. Petrópolis: Editora Vozes, 3 edição, 1998.

CHION, Michel. Audiovisão. Lisboa: Texto \& Grafia, 2011.

El Sonido: Música, cine, literatura... Tradução para o espanhol de Enrique Folch González. Paidós Ibérica: Barcelona, Buenos Aires, 1999.

"Le trois frontières". In: Un art sonore, le cinema: histoire, esthétique, poétique.

Paris: Essais, Cahiers du Cinèma, 2003. 
DELEUZE, Gilles. Sobre o Teatro: um manifesto de menos/ o esgotado. (L'épuisé, 1992). Zahar, 2010, 1 edição.

Diccionario de La Lengua Española - Real Academia Española, Vigésima segunda edição.

DIDI-HUBERMAN, Georges. O que vemos, o que nos olha. Tradução de Paulo Neves. 2 Edição. São Paulo: Editora 34, 2010.

. "De semelhança à semelhança: a semelhança interminável como vasta noite". Tradução de Maria José Werner Salles. Revista Alea, n. 13, volume 1, 2011. Acessado em 16/01/2013 http://dx.doi.org/10.1590/S1517-106X2011000100003

DOANE, Mary Ann. Zeno's Paradox: the emergence of cinematic time. In: The emergence of cinematic time: modernity, contingency, the archive. Harvard University Press, 2002, p 172206.

La Emergencia del tiempo cinemático: La modernid, la contingencia y el archivo. Murcia: Cendeac, 2012. Tradução Cálamo y Cran S.L., revisada por Marta Morales.

FERRAZ, Silvio. Música e repetição: a diferença na composição contemporânea. São Paulo: EDUC, 1998.

FENERICH, Alexandre Sperandéo. Questões da Representação na Música Eletroacústica. UFRJ/Escola de Música, 2005. Dissertação de Mestrado, 140 f.

GUBERNIKOFF, Carole. Música Eletroacústica: permanência da sensação e situação de escuta. Opus - Revista da Associação Nacional de Pesquisa e Pós-Graduação em Música ANPPOM, ano.11, n. 11, 2005. Acessado em 16/01/2013 http://www.anppom.com.br/opus/data/issues/archive/11/files/OPUS_11_full.pdf

HANSEN-LOVE, Mia. "Dangereuse jeunes filles". Cahiers du Cinèma, n. 593, crítica publicada em setembro de 2004.

LOPES, Denilson. A Delicadeza: Estética, experiência e paisagens. Brasília: Editora da UNB, 2007. No Coração do Mundo: Paisagens Transculturais. Rio de Janeiro: Rocco, 2012. 
KRISTEVA, Julia. Sentido y sinsentido de la rebeldía. Literatura y Psicanálisis. Tradução Guadalupe Santa Cruz. Editorial Cuarto Próprio, 1999.

MENEZES, Flo. Música Eletroacústica: história e estética. 2 edição. São Paulo: Editora da Universidade de São Paulo, 2009.

OBICI, Giuliano Lamberti. Condição da Escuta: mídias e territórios sonoros. Rio de Janeiro: 7 Letras, 2008

OUBINA, David. Estudio Crítico Sobre La Ciénaga: Entrevista a Lucrecia Martel. Buenos Aires: PicNic Editorial, 2007.

OLIVEIRA Jr., Luís Carlos Gonçalves de. O cinema de fluxo e a mise-en-scène. São Paulo, 2010, ECA/USP. Dissertação de Mestrado, 161p.

PAGE, Joana. Crisis and Capitalism in Contemporary Argentine Cinema. Duke University Press, 2009.

QUEIROZ, André; ALVIM, Luiza; OLIVEIRA, Nilson (ORGs). Apenas Blanchot! Rio de Janeiro: FAPERJ, 1 edição, 2008.

RÍOS-CORDERO, Hugo. La Poética de los Sentidos en Lucrecia Martel. ATENEA, VOL. XXVIII, n.2, deciembre 2008, Puerto Rico. Acessado em 16/01/2013

http://www.academia.edu/908033/La_poetica_de_los_sentidos_en_los_filmes_de_Lucrecia

$\underline{\text { Martel }}$

ROUDINESCO, Elisabeth; PLON, Michel. Dicionário de Psicanálise. Tradução Vera Ribeiro, Lucy Magalhães. Supervisão da Edição Brasileira Marco Antônio Coutinho Jorge. Rio de Janeiro: Zahar, 1998, p. 245. Ver termo Foraclusão (Verwerfung).

RODRIGUES, Rodrigo Fonseca e. A Experiência da música e as escutas contemporâneas. Revista Famecos. Porto Alegre, n. 19, dezembro de 2002, quadrimestral.

RUSSEL, Dominique. Lucrecia Martel - "a decidedly poliphonic cinema". In: Jump-Cut- a review of contemporary media, n. 50, Spring -2008. Acessado em 26/09/2011

http://www.ejumpcut.org/archive/jc50.2008/LMartelAudio/index.html 
SCHAFER, R. Murray. A Afinação do Mundo: uma exploração pioneira pela história passada e pelo atual estado do mais negligenciado aspecto do nosso ambiente: a paisagem sonora. Tradução Marisa Trench Fonterrada, São Paulo: Unesp, 2001.

SCHAEFFER, Pierre. Tratado de los objetos musicales. Título original "Traité des objets musicaux (versión abrégée, 1966)”. Versão espanhola de Araceli Cabezón de Diego. Alianza Editorial: Madrid. Primeira Edição,1988.

"Esquisse d'une solfège concrète". A La Recherche d'une musique concrète. Paris: Seuil, 1952.

SEICMAN, Eduardo. Estética da Comunicação Musical. São Paulo: Via Lettera, 2008.

STAM, Robert. Introdução à teoria do cinema. Tradução de Fernando Mascarelo. Campinas: Papirus, 2003.

STRAUB-HUILLET. "Entrevista com J.M. Straub e D. Huillet - Sobre o Som”. Cátalogo da Mostra STRAUB-HUILLET, 2012, CCBB. Tradução do francês de Bruno Carmelo, de trechos da entrevista publicada na revista de música italiana GONG e posteriormente na Cahiers du cinéma, "Entretien avec J. M. Straub et D. Huillet - Sur le son", números 260, 261, outubro e novembro de 1975 .

VALENTE, Heloísa de Araújo Duarte. "Por uma escuta clariaudiente da canção das mídias". In: IASPM - Asociación Internacional para el estudio de la música popular. X Congresso de IASPM-AL. 18 à 22 de abril de 2012, Córdoba, Argentina. Anais. Acessado em 16/01/2013: http://www.iaspmal.net/wp-content/uploads/2012/01/heloisadearaujo.pdf

Os cantos da voz: entre o ruído e o silêncio. São Paulo: Annablume, 1999.

WISNIK, José Miguel. O Som e o Sentido. São Paulo: Companhia das Letras, 2007.

ZAGONEL, Bernadete. Entrevista com Pierre Schaeffer. Opus - Revista da Associação Nacional de Pesquisa e Pós-Graduação em Música - ANPPOM, ano.11, n. 11, 2005. Acessado em 16/01/2013, http://www.anppom.com.br/opus/data/issues/archive/11/files/OPUS_11_Zagonel.pdf 
ANEXOS 


\section{a. Entrevista com Guido Berenblum, diretor de som dos filmes da cineasta Lucrecia}

Martel.

\section{Introdução}

Após ter participado do seminário "O som no cinema contemporâneo: conceitos e novas tecnologias", na semana da A.B.C. 2012 (Associação Brasileira de Cinema), o diretor de som argentino Guido Berenblum nos falou sobre a importância de se pensar a sonoridade de um filme durante todo o processo da sua criação. No seminário que aconteceu na Cinemateca Brasileira, em São Paulo no dia 11 de maio, Berenblum destacou partes do roteiro do filme O Pântano (2001), escrito e dirigido pela cineasta Lucrecia Martel, nos quais apareciam indicações sonoras concretas. Segundo Berenblum, o trabalho de um diretor de som perpassa pela concretização dessas indicações sonoras do roteiro, pela definição das escolhas técnicas e de um fluxo de trabalho com o som ao longo do processo criativo do filme. Conversas prévias a gravação do som podem, antes de tudo, definir um "modo de acercarse", uma opção estética para o filme que inclua os sons.

O técnico de som direto e editor de som cinematográfico é diretor de som dos filmes $A$ Mulher Sem Cabeça (2008) e A Menina Santa (2004) da cineasta Lucrecia Martel; Café dos Maestros (2008) de Miguel Kohan; Hamaca Paraguaya (2006) de Paz Encina; Los Guantes Magicos (2003) de Martin Rejtman; Garage Olimpo (1998) de Marco Bechis, entre outros. Ministra a oficina "Edição de Som em Formato 5.1", na Escuela Internacional de Cine y Televisión de San Antonio de Los Baños (EICTV) desde 2010.

Em conjunção à conversa inicial, anexamos uma segunda parte da entrevista, realizada em Buenos Aires (julho de 2012), na qual Berenblum falou sobre temas relacionados ao uso do som nas películas em que trabalhou como diretor de som, sobre o início da sua carreira profissional e sobre sua parceria com a cineasta Lucrecia Martel.

\section{DC - Como começou a sua trajetória profissional no cinema?}

Guido Berenblum - Eu comecei quase por acidente a minha história com o cinema. Quando estava no ensino médio estudava percussão e bateria e tinha um amigo que trabalhava com um músico que se chama Leo Sujatovich, e que foi durante vários anos o tecladista do músico 
super conhecido na argentina, o Luís Alberto Spinetta ${ }^{60}$. Esse meu amigo sumiu do emprego e acabei ocupando a vaga dele, como assistente desse músico. Fiquei trabalhando para ele durante um ano e nunca tive contato com os equipamentos de som. Mas, foi lá onde conheci um técnico de som que possuía um programa de estudos de gravação de som, de uma universidade americana que tinha estudado. Começamos a estudar junto esse programa. Ao mesmo tempo, eu tinha um amigo que estudava numa escola de cinema em Buenos Aires e me chamou para ajudar a finalizar o som de um curta-metragem em super-8. Bom, trabalhei neste curta e descobri um mundo completamente novo pra mim, alucinante, que foi uma espécie de vírus que me atingiu. Depois trabalhei em distintos estúdios, muitas vezes de graça, para adquirir experiência. Também fiz muita dublagem de programa de televisão, filmes e documentários. Também fiz muitos outros curtas-metragens de cineastas que atualmente são consagrados, mas que na época estava também no início de suas carreiras. Depois fui trabalhar em um estúdio dos técnicos de som Carlos Abbate e Jose Luis Díaz. Estas duas figuras do cinema argentino foram muito importantes para mim porque foi com eles, neste estúdio, que pude completar minha formação como técnico de som ao longo de quatro anos. Depois de algum tempo, em 1997, um diretor me ofereceu a oportunidade de participar do seu filme como diretor de som acompanhei todas as etapas do processo de gravação e pós-produção do som.

D.C - Guido, gostaria que você falasse um pouco sobre as suas escolhas para o uso dos sons nos filmes da Lucrecia Martel. Em $O$ Pântano, vocês mostram os sons sem revelar a imagem da sua fonte sonora. É como se tentassem desvincular os sons das suas causas para criar uma forte sensação de expectativa, de tensão para o espectador. Tem um músico concreto, o Michel Chion (Audiovisão, 2010) que nomeia esse som como acusmático. Um som fora-de-campo que pela sua repetição, sem revelar a sua imagem física, incita a curiosidade e o olhar do espectador. Com diferentes ritmos e tons, o som cria uma experiência audiovisual que coloca o ouvido e a mente do espectador num "estado de espera" contínuo em relação a resolução dos eventos sonoros ocultos na imagem. Neste primeiro filme, tal revelação é adiada até uma das últimas cenas do filme,

$60 \quad$ Luís Alberto Spinetta foi um guitarista, poeta e compositor precursor do rock argentino. Conhecido como El Flaco, o músico que morreu em 2012, tocou em diversas bandas, dentre elas Almendra. O site do músico (http://www.spinettacual.com.ar/ ) foi acessado em 16/08/2012. 
com a constatação da personagem Momi (Sofia Bertolotto) de que "no vi nada". Gostaria de saber como foram as escolhas em relação ao tratamento e ao uso do som nesta primeira parceria de trabalho entre vocês? Vocês pensaram antes das filmagens em como concretizar esses eventos sonoros presentes no roteiro?

GB - Bom, para começar, eu tenho uma pequena parcela de responsabilidade em relação ao som desta película, já que não participei de todos os processos de pós-produção, gravei o som direto, montei os diálogos e fiz todas as dublagens. Acho que essa questão, talvez pudesse ser bem respondida pela Lucrecia Martel e pelo Hervé Guyader, o chefe da edição de som. Mas, enfim, posso te dizer que $90 \%$ dos sons das películas da Lucrecia surgem do pensamento dela. Nós podemos fazer um montão de sugestões, por um lado é a maneira como a gente traduz essa questão em algo real, por outro lado tenho a sensação de que muito do que voce aponta nessa questão analítica sobre o som não sei se nasce de um pensamento intelectual de uma forma de contar, mas de uma forma que foi se construindo sobre a prática. Dos fatos se chega a uma forma de contar, que nasce de uma ideia concreta que vem do roteiro, quando falamos do princípio da película. Também deveríamos discutir, sobre esse exemplo em relação aos sons off, acusmáticos. Há quem diga que os sons nunca estão off, porque antes de tudo, são invisíveis, mas estão aí, são reais. O que temos é o enquadre do nosso olhar; os sons do rumor da cidade e do bafo de trânsito em uma cena dentro de um quarto estão contidos numa cena, somente estão fora do campo de visão que a câmera quer nos mostrar. Então, isso é uma discussão filosófica, que não tem muita importância na prática. Agora, gostaria que vc me desse um exemplo particular dessas películas, quais são os eventos que pode me apontar.

D.C - Por exemplo, os latidos do cachorro, que no início do filme aparecem como um ruído banal, cotidiano e que depois se transformam em um som mais monstruoso, contaminados por uma fábula sobre a rata-africana contada pelos personagens adolescentes. No filme, acompanhamos a imaginação da criança Luchi (Sebastián Montagna) em relação à esse som que não se vê até o ponto desse som se transformar na causa que incita uma curiosidade mortal e culmina no final do filme. Outro exemplo seria a ambiência construída com os tiros e trovões no início do filme que demarcam uma instabilidade na narrativa - a presença da precipitação de um acidente que pode se concretizar a qualquer momento. 
GB - Para mim, o ponto mais importante de toda essa questão é que o som se torna muito mais subjetivo, sugestivo e atrativo quando se escuta, mas não se vê. Isso exige e gera inquietude, não uma inquietude por estar imóvel, mas uma inquietude no sentido de ficar procurando sempre “o que é isso? O que está acontecendo?". Inclusive, não se chega a perguntar o que é isso? A película segue correndo, passando adiante no tempo, correndo pelos olhos e ouvidos do espectador. Em um tempo que não se pode deter essa película, ela segue avançando, segue passando coisas; mas ao mesmo tempo estou em um segundo nível de atenção escutando que há algo que não segue. Isso expande muitíssimo o espaço fílmico e exige do espectador um compromisso de alguma maneira, senão um engajamento que também pode causar outro efeito, que é o de perder-se totalmente e desistir desse compromisso com a película. Não sei o quanto de tudo isso é uma questão tremendamente intelectual, me parece que é um pouco do que havíamos falado antes, de uma cultura auditiva que existe. Não como uma cultura auditiva formal, acadêmica, não é isso, mas uma cultura de reconhecer que somos capazes de ouvir no nosso cotidiano, em reconhecer situações sonoras que traz consigo mesmo um legado que trazemos de nossa infância, de coisas muito comuns. Eu por exemplo, me dei conta disso, do que se passa com as pessoas desde a infância. Todas essas impressões da vida também são impressões sonoras, simplesmente vivemos recordando coisas que estão envoltas em sons, que produziram sonoridades diferentes. Podemos então falar de cultura auditiva, mas, com certeza, a possuímos desde crianças. Então, acho que toda essa questão sobre o uso do som no espaço fora-de-campo que aparece nas películas de Lucrecia Martel estão dadas também porque ela mostra uma parte muito particular com a câmera e deixa um mundo afora. Se pensarmos, podemos dar como exemplo suas últimas películas, A Menina Santa (2004) e A Mulher Sem Cabeça (2008), aonde corta as cabeças dos personagens para fora-de-quadro com um enquadramento axial, convertendo uma situação muito simples em uma situação enrarecida.

Se você está acompanhando uma situação na imagem e, de repente, alguém levanta e tem cortada a sua cabeça isso gera uma estranheza, porque estamos acostumados a ver as pessoas falando em quadro. Ao mesmo tempo, essa situação me atrai ainda, porque sigo escutando o diálogo. Também temos uma questão em relação à distância, porque temos o quadro fixo, as pessoas seguem seus caminhos, levantam e o quadro se mantém fixo. $\mathrm{O}$ enquadramento e posição da câmera mantêm um olhar como se alguém estivesse espiando por uma fresta ou por uma fechadura. Neste lugar, por mais que a pessoa se mova não consegue variar muito o campo de visão, mas segue escutando tudo isso. Então, acho que os filmes 
mantém um pouco essa sensação.

D.C - Concordo com você Guido, quando aponta essa relação entre o som e a imagem no filme da Lucrecia. $O$ enquadramento axial, que divide o corpo entre as regiões cranial e caudal; a posição ritualizada dos corpos na horizontalidade, como se estivesse em "estado de espera" e a movimentação dentro do quadro ressaltam mais ainda essa função dos sons fora-de-campo. Mas, ainda tenho outra pergunta. Assistindo A Menina Santa e A Mulher Sem Cabeça tive a impressão de que existe outro fator decisivo nessa articulação entre som e imagem, que aparece como uma eminência constante: a presença da morte. Na Mulher Sem Cabeça, isso é bem mais evidente, com a confirmação da morte de uma criança; mas na Menina Santa essa presença para mim surge sutilmente, ainda na primeira cena da piscina, na qual Helena (Mercedes Moran) comenta para Amália (Maria Alché), que está cansada, mas usa a palavra morte - "no estás como morta?". Depois, essa ideia sobre a morte aparece em diversas situações: em comentários, quando Amália comenta que o quarto da mãe parece uma tumba; com Josefina (Julieta Zylberberg) assustada, falando sobre um homem nú que cai do telhado e surge na cena atrás de um véu de cortinas brancas - "são reflexos de um morto". Mais adiante, temos uma cena em que Helena aparece em uma posição estranha, deitada de bruços sobre uma cama, imóvel como se estivesse morta. Enfim, gostaria de pontuar esse motivo, que para mim está impregnado nos filmes conferindo esse clima de suspense, da eminência de uma catástrofe. Como se o ambiente que os personagens convivem estivesse ameaçado pela presença constante de uma assombração, a qual mencionamos, mas nunca vemos. Esta primeira cena da piscina, em A Menina Santa, foi editada por você?

G.B - Não, eu gravei o som direto e editei uma parte do dos diálogos, do som ambiente, mas não fui eu que editei essa cena, tudo isso foi feito no Chile, com David Miranda.

D.C - Bom, eu gosto muito desta cena, porque a articulação entre o som e a imagem, mais especificamente, os enquadramentos das orelhas e o movimento rítmico criado pela inclusão e a retirada de sons das cigarras, sobrepostos pelos sussuros da Amália (Maria Alché), tudo isso parece pontuar a marcação de um ponto de escuta subjetivo da protagonista. Uma experiência auditiva da personagem, particular e única, pontuada 
por sons invisíveis e inaudíveis para o espectador e que só ela escuta. Assim, como somente Amália escuta o som inaudível - um sinal de Deus da sua vocação religiosa. $O$ que representa esse sinal inaudível no filme? Ou ainda, o que representam nesta narrativa o ruído estridente do Thereminvox, o estrondo da queda do homem nú ou o bel canto entoado por Mia Maestro no início do filme? Tenho a impressão de que nunca vamos saber responder essa pergunta, porque o som desta película parece habitar um lugar ambíguo, que não se classifica nem como unicamente objetivo, nem como subjetivo. Pontuo que, antes de tudo, usar ruídos banais para representar um pensamento ou um estado de espírito de um personagem é diferente do que usar uma voz, mais ainda, do que usar um diálogo para explicar as causas dos acontecimentos. Desde o primeiro som destas películas, os escutamos descolados da imagem referida. Tenho a impressão de que a edição e a mixagem desses sons acentuam uma diferença na ambiência a cada corte na imagem - que mostra o primeiro plano da orelha de Amália e Dr. Jano. O som exerce uma dupla função, assim como a palavra, confere ritmos e ambientes sonoros as imagens, mas também "significa algo" porque se refere ao cotidiano desses personagens, têm um sentido ambíguo na narrativa. Nesta cena, Amália olha Jano, Jano olha Helena e depois Amália vê Dr. Jano olhar Helena. Estes três pontos são marcados pela variação dos sons ambientes e por esses cortes que mostram em primeiro plano a orelha. Sendo que, no plano que mostra Helena andando dentro da piscina, vemos à distância ela segurar a própria orelha. Um acúfeno inaudível a molesta? Ouvimos esse som inaudível que emerge do silêncio? É sobre esse uso figurativo do som que quero perguntar. Somente, Jano e Amália desejam pelo olhar e mostram o espaço pelo seu ponto de vista. Nos três momentos de variação de intesidade e de ritmo dos sons ambientes que temos nesta cena, ouve-se um ruído de som sugado, de força centrípeta. Enfim, temos todo um ambiente sonoro dado pelo movimento e textura desses sons, uma atmosfera que nos filmes se torna mais ambígua pelo uso desse tema auditivo, pelo destaque das orelhas, por pequenos eventos sonoros.

G. B. - Esse ruído entra com a frase "34 graus", isso também está vindo de qualquer lado, “quien hablo?”,61 , já que não vemos a imagem dessa voz masculina que diz a temperatura da água (neste plano, vê-se Amália deitada em primeiro plano e ao fundo uma piscina aonde está

61 É também a fala dita por Mercedes Morán, que está fora-de-quadro neste primeiro plano da cena. 
nadando Dr. Jano). Também aqui tivemos um problema nas filmagens. Esta cena foi gravada perto de uma mata e gravamos à noite, na verdade, na última hora da tarde. Estava cheio de insetos do ambiente que apareceram na gravação do som direto. Então, fizemos de um problema técnico uma escolha estética e cobrimos com mais ruídos de insetos alguns trechos do filme. Nos momentos em que Amália sussura, ouve-se menos esses ruídos porque dividimos o espaço dado ao ruído com a voz, divimos nossa atenção auditiva entre esses dois elementos. Quando nesta cena, troca-se o ponto de vista sonoro de Amália para Jano existe um enrarecimiento, uma diminuição da densidade dos sons ambientes para através do uso do silêncio conferir mais tensão à cena. Aqui, temos que levar em consideração essa questão dos insetos que foi assumido como uma marca do filme, assim como em $O$ Pântano.

\section{C. - É engraçado, porque ao mesmo tempo em que essa marcação tenha sido realizada para cobrir um "defeito" técnico, eu tenho a impressão que o montador se aproveitou disso para marcar a experiência auditiva da personagem Amália.}

G. B - Sim, sim, e acho que marca também essa experiência auditiva com o silêncio, porque muda a qualidade sonora quando deixa isolado o personagem Jano, confere mais silêncio neste momento, a mim me soa um pouco artificial, mas depois retira o silêncio. No sentido, de que quando o olhar de Jano encontra Helena estão isolados, concentra-se uma atenção aí.

\section{D.C. - Guido, no momento da captação dos sons, ou antes, mesmo, ou se foi no momento da pós-produção, enfim, gostaria de saber se você e Lucrecia discutem muito sobre o uso do som nas películas ou se as coisas surgem intuitivamente?}

G.B - Sim, de algumas cenas falamos especificamente sobre o uso do som, em outras vamos recorrendo aos caminhos que surgem na criação do filme. Vamos ajustando as coisas. Um exemplo mais concreto posso te dar com uma cena de A Mulher Sem Cabeça, quando Verônica vai ao campo de futebol. Essa cena começa com um plano geral muito grande e com muitas informações: tem crianças jogando futebol, um esguicho espirrando um jorro d'água e muitas mulheres caminhando ao redor do campo de futebol, numa pista de atletismo. A água esguicha e vai criando uma névoa esbranquiçada ao redor da pista, quando a Verônica e as outras mulheres passam ao lado de um alambrado, que divide o campo de futebol das crianças pobres (fora-de-quadro) e a pista de atletismo dos sócios do clube ouvimos um estrondo da 
bola batendo no alambrado que chama a nossa atenção para essa divisão. Isso foi um delírio meu, porque não tinha uma justificativa narrativa para esse evento sonoro acontecer, mas tinha uma vontade minha de organizar e amarrar tudo nesse plano a partir de uma cadência, pelo movimento dos sons. Isso porque tínhamos um som insuportável neste plano, o esguicho de água - um som muito irritante, áspero, mas também muito rico porque fica muito tempo soando, um ruído contínuo. Então, não podíamos retirá-lo e, ao mesmo tempo tínhamos que apresentar os garotos jogando, chamar a atenção do espectador para este outro foco. Junto com os garotos tinha um treinador, com um jeito pseudo-militar - dando ordens aos garotos mas não estava muito claro essa fala, já que não queríamos colocá-la em primeiro plano sonoro. Então para mim, tinha que acontecer algo que fosse muito violento, um chacoalhão, como o que aconteceu no momento do acidente. Não vimos o acidente, mas pressentimo-lo por causa desse estrondo, que é uma situação violenta e que não foi contada de uma maneira clássica, porque vemos de um ponto de vista que não nos mostra o espaço, não é o do protagonista e nem da vítima. Esse ponto de vista se encontra ao lado da protagonista, mas não nos informa muito que se passou. E o que eu procurava para esta cena do campo de futebol era reviver um pouco essa sensação desmedida, portanto procurei um estremecimento que remetesse à violência que existiu na cena do acidente, como se fosse um estremecimento que marcasse a culpa da protagonista. Bom, depois de alguns planos, essa mesma protagonista assume de uma maneira muito banal, dentro de um supermercado na fila do caixa que matou alguém. E pensamos, como? Nesta situação também, usamos todos os tipos de ruídos do supermercado, pessoas passando ao seu redor, existe muita movimentação nesta cena e a personagem resta apática, imóvel, sua presente é notada apenas por esta frase. Então temos uma cena que é banal, cotidiana e tem uma resolução estranhíssima.

Bom, de todas as maneiras, temos dada essa situação onde a câmera não revela de onde veio esse ruído fora-de-campo, acusmático. Prosseguindo com o exemplo da cena do campo de futebol... No plano seguinte, vemos um menino caído no chão. Temos outro plano, da protagonista entrando no banheiro. Neste banheiro se escuta os gritos das crianças jogando basquete e que chegam de todas as direções. Depois ouvimos um ruído estranho que assusta Verô (Maria Onetto). Um homem com uma solda saí detrás da porta do banheiro. Seguimos escutando o som fora-de-campo das crianças enquanto Verô abraça aos prantos o soldador, que sai do quadro. Escutamos então todo um barulho de moeda, depois sons de moedas e um objeto mais pesado caindo numa máquina. Enfim, no próximo plano o soldador retorna segurando uma água e a joga no pescoço de Verô. Toda a ação do personagem foi dada pelo 
som fora-de-campo e outras muitíssimas coisas acontecem fora-do-campo, mais ou menos resolvidas. Neste contexto, os sons das crianças tornam-se super agressivos, em outra ocasião talvez não.

Beatriz Cruz $^{62}$ - No roteiro Guido, estava previsto o que vai estar no campo de visão do espectador e que estará fora-do-campo?

G.B - Não. Isso decidimos no momento da filmagem, exceto algumas coisas que vieram marcadas como, por exemplo - se segue escutando tal coisa....Ela [Martel] decide isso no set de filmagem.

B. C - Por exemplo, nesta cena que você descreveu, onde muitas coisas acontecem forade-campo, quantos microfones usaram?

G. B - Não me recordo muito bem, mas geralmente uso apenas um microfone (em momento posterior, na entrevista em Buenos Aires, Berenblum completa a informação falando que usaram 3 microfones - um boom e dois lapelas, mas só foram úteis no momento do abraço). Bom, eu prefiri usar também um microfone aéreo porque havia contato físico - os abraços - e os lapelas soam muito ruins para esse tipo de gravação. Usei as lapelas, mas também era uma situação que podia ser resolvida com um boom porque não havia quase texto, o soldador pergunta - "se siente bien" e Verô (Maria Onetto) responde - "Gracias". Nesta cena, a atriz Maria Onetto chorou de verdade, de uma maneira muito intensa, mas em silêncio e estava de costas, também não vemos. Então fiquei em dúvida, se colocava ou não uma dublagem aí de soluços. Mas esses sons orgânicos são difíceis de dublar, é difícil para o ator recriar isso com credibilidade. Mas não, enfim, a gravação de som desta cena foi muito simples. Gravamos separados os ruídos da máquina, em outro local. Depois gravamos também em separado os ruídos elétricos do soldador, no local mesmo, e foi isso. Bom, e num momento posterior, com certeza, isso tudo foi um pouco mais trabalhado em pós-produção. De todos esses filmes com a Lucrecia, talvez o mais difícil de captação de som direto foi o primeiro - O Pântano. Porque tinha outra dinâmica, haviam situações muito mais complicadas, com muitas pessoas. Há também situações dessas em A Menina Santa, com pessoas falando, entrando e saindo do

62 Beatriz Cruz é atriz da encenação em processo de montagem "Salta! Uma reação à Lucrecia Martel”, uma pesquisa de criação e encenação teatral do Coletivo Teatro Dodecafônico em reação as obras de Lucrecia Martel. 
quadro. E isso, que parece ser super complicado do ponto de vista do registro do som direto pode ser resolvido com um único microfone. Se tenho um microfone escondido aonde o personagem vai passar [fora-do-quadro] ou mesmo um lapela, (mas não seria muito eficiente usar uma lapela, já que desejo dar uma sensação que o som está se afastando, porque o lapela me proporciona esteticamente um plano sonoro muito próximo, escutando acerca da orelha)... Portanto, filma-se, os atores dizem os textos e nós captamos o som de um único ponto se estão fora-de-quadro. Eu estava dizendo outro dia, que existem momentos em que usamos o som desta maneira e outros momentos resolvemos de outra maneira o registro desse som. É também uma maneira de resolver em relação ao orçamento muitos problemas na rodagem. Com o registro do diálogo fora-do-quadro, a questão toda é saber como gravar isso. Se peço para um ator falar há 4 ou 5 distâncias diferentes do microfone, vou ter também muitas possibilidades de escolha e alguma terá que servir. Essa é uma maneira de gravar o som direto que aprendi com a experiência, no dia-a-dia, mas talvez para outros técnicos de som esse registro poderia ser resolvido de outra maneira, cada um tem o seu estilo. E essa minha maneira, talvez se aplique no meu trabalho com Lucrecia Martel, mas nem sempre com outros cineastas. Por exemplo, sobre essa película que falei, de um amigo meu (JUNTOS PARA SIEMPRE, de PABLO SOLARZ), os textos tinham que ser ditos da mesma maneira em que estavam escritos, essa maneira de gravar o som não funcionava. Primeiro, porque nunca se recordava os textos e depois porque eram textos extensos, então como colocar esse texto em sincronismo com a imagem depois?... Não havia onde cortar, então não funcionava.... Estou tentando lembrar de um exemplo deste filme, enfim, acho que tínhamos uma sala muito grande e chovia muito. $\mathrm{O}$ ator tinha que falar ora muito longe ora muito perto da mãe que estava sentada em um ponto da sala, mas estava impossível porque havia muita interferência, muita chuva, o lugar era muito grande, mais difícil de controlar a acústica. Não se podia dublar, porque não ia ter dublagem, então tínhamos que gravar e depois tentar tratar esse som, com muitos planos distintos e diferenças de qualidades sonoras, diferenças de qualidade de atuação e nada funcionava, os sons não se igualavam em termos de acústica... Então, nesta situação é muito mais difícil captar o som de um único ponto, porque esse ator se movimenta dentro do quadro e está ora mais próximo e ora mais distante. Igualmente, tem uma parte disso tudo que pode ser resolvido com efeitos de reverberação, em pós-produção, mas na verdade é que se tenho a acústica do lugar é muito mais fácil se aproveitar disso.

D.C- Em relação ao volume de som usado nos filmes da Lucrecia, tenho uma sensação 
auditiva de que foram usados sons muito mais intensos e densos para compor os ambientes sonoros no Pântano do que em A Mulher Sem Cabeça, onde os ruídos aparecem mais sutis, em volume mínimo. Não sei, a seqüência de abertura dos dois filmes me passa essa impressão. O Eduardo Santos Mendes gosta de falar em sala de aula que nos filmes da Martel, já na primeira cena, temos um resumo, uma sonoridade anunciada que nos fornece uma impressão geral do filme, uma percepção auditiva do que aparecerá nos próximos planos. Já nos primeiros minutos, ao assistir estes filmes o espectador terá que lidar com um "ouve-se de tudo e vê-se de menos" ou como você mesmo disse, vê-se pelas frestas. Mas, deste ouve-se, temos diferentes tipos de experiência auditiva ao assistir os dois filmes. Podemos com certeza, ampliar essa experiência sonora para um modo de percepção global, que compreende uma experiência mais ampla, a audiovisual. A temporalidade e a movimentação dos sons destes dois filmes parecem ser muito diferentes, e não só pela opção de fixar a câmera e diminuir os acontecimentos da narrativa. Na terceira película nos concentramos praticamente, em um único evento e uma única personagem, mas também temos menos eventos sonoros e ruídos menos estridentes. No primeiro filme, vocês elegeram o ruído das taças, trovões, uma chuva mais tórrida, tudo externo a casa parecia ser violento, mais estridente, mais intenso. E não sei, mas em A Mulher Sem Cabeça, tenho a impressão que tudo está mais contido, que os sons dos objetos são mais silenciosos, como se experimentassem representar um escuta mais íntima do personagem. Escuto algo como sininhos metálicos que desaparecem, sutilmente, ao passar um carro, depois escuto um pingo da chuva mais grosso até se transformar em gotículas de chuva... Enfim, acha que vocês foram mais contidos no uso dos sons neste filme? Não quero contestar o seu exemplo sobre a busca de um estrondo na cena do campo de futebol, mas me parece que neste filme vocês foram muito mais contidos em relação a densidade do espaço sonoro?

G.B - Não consigo perceber isso em relação ao som. Na verdade, neste filme tínhamos menos diálogos, então, talvez por isso, você teve essa sensação auditiva. Neste filme, o que se fez foi modificar a velocidade da câmera (creio que filmamos em $30 \mathrm{fps}$ ), porque quase não vemos as bocas e tem-se muito pouco texto em quase todos os planos, então o som fora de sincronia percebe-se menos, está muito sutil. O som é o da tomada em tempo real, mas a imagem não, porque queríamos ressaltar uma sensação de que o tempo está passando mais devagar, um leve descompasso nas ações do filme. 
D.C- Guido, li uma entrevista sua e da Lucrecia para a SonidoAnda (palestra na FADU em 2008), onde vocês comentam sobre o uso dos sons dos objetos em cena. Nos filmes da Lucrecia isso teria produzido o que você denominou como um "modo de acercarse". Nessa mesma entrevista, a Lucrecia fala sobre os seus primeiros contatos com um espaço sonoro e narrativo através de diferentes ambientes sonoros e diferentes sentidos experimentados na escuta dos contos narrados pela sua avó, quando ela era criança. Também me lembro de ler outra entrevista dela para o crítico Jean Michel Frodon, em 2004, no lançamento da Menina Santa em Cannes (Cahiers du Cinema, n. 593), onde ela comentou que os sons conferiam uma tonalidade sonora (tonalité sonore), como se fossem um guia para definir as regras da mise-en-scène dos filmes. Enfim, na busca da concretude, vou lembrar um exemplo disso para mim nos filmes. Em todas as três películas, pode-se apontar momentos em que alguém conta algo ou rememora um evento e ocorre variações do ambiente sonoro, conferindo um clima de suspense. Em $O$ Pântano, temos a fábula da rata-africana que é contada por uma das adolescentes (Vero, Leonora Balcarce); em A Menina Santa, a amiga da Amália (Maria Alché) e Josefina (Julieta Zylberberg) também conta uma história de terror popular, sobre uma mulher que pede ajuda na beira da estrada para salvar um bebê, mas na realidade está morta. No terceiro filme, posso lembrar a cena da avó vendo o vídeo e escutando uma voz estranha, de uma pessoa morta. Enfim, talvez nos dias atuais, com a violência muito real e audiovisual, a eminência da morte saída da boca de crianças ou lembrada por uma idosa de cama já não seja assim tão impressionante e assustador. Porém, acho que, de alguma maneira, o espaço sonoro da experiência auditiva infantil da Lucrecia permeia esses filmes, como se fosse mesmo uma "puesta en escena sonora" única ou como você mesmo nomeou, como um "manera de acercarse" através das impressões auditivas. Quero que você fale um pouco sobre esse "modo de acercarse". O que da sua maneira de gravar os sons contribuiu para concretização desse "modo de acercarse". Você consegue lembrar se, nestes três momentos, vocês captaram os sons e as vozes com diferentes distâncias e enquadramentos (posições) de microfones? As variações das qualidades acústicas do som ambiente como sua textura, intensidade e o ritmo, captadas pelo som direto foram decisivas para criar esse clima de suspense?

G.B. - Na realidade, se trata antes de tudo de uma resolução em função do que acontece no ambiente de filmagem, plano a plano, pensando sempre em como se dará o processo de montagem. Reunimos-nos para pensar sobre a nossa intenção do uso do som, mas nunca 
sabemos como vamos resolver um cena, antes de chegar no set de filmagem. Portanto, não há uma discussão prévia as filmagens sobre as distâncias do microfone ou sobre a acústica do lugar. Contudo, sempre a produção dos filmes e a própria Lucrecia se encarregam de reservar um tempo na diária de filmagem para poder gravar os sons que não foram captados nas tomadas de som direto - vozes, diálogos fora-de-campo ou qualquer outro som que necessite desse cuidado. Então, terminamos as rodagens uns 40 minutos antes e se gravam estes sons.

\section{C - Sobre A Menina Santa, você comentou que gravaram muitos offs de sons do hotel,} coberturas de vozes que não se encontravam na cena e que nem tudo foi usado na mixagem. Vocês colocaram um pouco dessas vozes no surround para criar um desenho no ambiente sonoro? Esta escolha não é uma decisão muito comercial para distribuição de filmes em países de línguas diferentes, já que fica inviável fazer legendas para essas vozes. Em relação ao desenho dessa faixa sonora, a quantidade de sons gravados no ambiente pode tanto contribuir, fornecendo mais informações acústicas do espaço, mas também pode atrapalhar pelo volume e excesso de sons para organizar no processo de montagem e mixagem. Quais as dificuldades no mercado internacional por manterem essa escolha na mixagem?

G. B. - Essa mesma situação está presente em A Mulher Sem Cabeça, em relação a sua distribuidora internacional - a Focus Internacional. A banda sonora internacional (M\&E) foi rejeita pela distribuidora porque se ouviam vozes em espanhol nos ambientes. Como exemplo, posso destacar uma cena na abertura do filme, em um plano onde se escuta as vozes de crianças brincando (fora-de-campo), enquanto algumas mulheres passam perfumes e carregam bandejas de alumínio (formas de forno). Em geral, os dois filmes foram mixados cheios de vozes no som ambiente, porque são parte fundamental da trama, da sonoridade desses ambientes. Nunca poderíamos ouvir estes ambientes sem vozes, como se fosse um ambiente "neutro", e muito menos com vozes dubladas. Além disso, estas vozes foram gravadas em Salta devido a sonoridade do sotaque local, nunca teriam a mesma importância na trama se fossem gravadas em Buenos Aires. Então, foi uma decisão da Lucrecia Martel manter essas vozes na banda sonora e não modificá-las. Para manter essas vozes na banda internacional, foi necessário que a diretora enviasse uma carta para a Focus, aonde afirmava que de nenhuma maneira se aceitaria que fossem retiradas estas vozes dos ambientes e que não deviam dublá-las, já que se tratava de uma decisão estética dela, essencial para definição 
da mise-en-scène dos seus filmes.

\section{b. Decupagens dodecafônicas}

Ao longo desta jornada, encontrei pelo caminho outras pessoas que se interessavam pelos filmes de Lucrecia Martel. Todas elas vislumbravam um encontro com a obra da cineasta que pudesse proporcionar material de pesquisa acerca de um tipo de encenação contemporânea, às voltas de uma intimidade cotidiana. Nesta busca, todos juntos, descobrimos que aquilo que era comum, familiar, também poderia transformar-se em algo familiarmente estranho, selvagem. Na busca de uma encenação mínima, pesquisamos os procedimentos de escuta e de visão da cineasta e nos detivemos, ao longo de meses, numa minuciosa decupagem dos filmes da cineasta. Esta escrita pontual, feita por diversas mãos e pensamentos, destaca gestos, sons e enquadramentos que se repetem insistentemente nos três filmes da cineasta. Abaixo, destaco a decupagem dos três filmes usadas no processo de pesquisa da encenação teatral ;Salta!, uma produção do Coletivo Teatro Dodecafônico. 


\section{Decupagem "La Ciénaga", 2001.}

Alguns cortes se referem a uma seqüência de imagens/sons, outros são propostas para a observação de enquadramentos, como fotografias estáticas, que podem nos interessar.

\section{0:00 até 02:24 - Abertura do filme}

- Plano dos pimentões secando ao sol, com a iminência da tempestade ao fundo;

- Plano das cadeiras sendo arrastadas - recorte fragmentado de pedaços de corpos

- Plano em que Momi sussura deitada na cama - "Graçias por dar-me Isabel!"

Pontos a serem considerados neste trecho:

Nesta primeira sequiência do filme, temos uma montagem paralela que alterna 3 espaços diferentes até o momento em que as taças quebram.

Temos a apresentação do espaço externo, do mais distante ao mais próximo, ou seja, da floresta e da pileta suja até o espaço interno da casa. Sendo que no espaço externo a câmera é instável, parece se contaminar pelos corpos dos personagens.

Já no espaço interno da casa, a câmera mostra planos mais fixos (sendo, que nesse espaço, a câmera, gradativamente, vai se tornando instável, até um certa "sobriedade" no final do filme). Nesta primeira cena, no espaço interno são apresentadas as figuras de Momi, Isabel e Véro, deitadas na cama.

Nessa seqüência, a perseguição na mata tem a imagem suprimida, porém continuamos ouvindo o som dos tiros. Esse efeito serve para ligar temporalmente os espaços ao próximo plano, de Mecha deitada na esteira. A ligação entre os planos é tão evidente, que Mecha olha para a esquerda, como se ouvisse o tiro.

\section{5:42 - Plano das cadeiras - ENQUADRAMENTO (plongée)}

Imagem estática das pessoas largadas nas cadeiras.

\section{$08: 30-09: 20$}

Neste trecho podemos notar que os objetos sonoros ganham "vida própria" e são utilizados para reforçar os momentos de quebra no texto ou nas ações empregadas nessa narrativa: o rádio que liga sozinho no carro, o secador de cabelo de Gregório que dificulta a conversa com Momi, a presença da chuva que expulsa (dá mobilidade) aos sedentários amigos de Mecha da pileta.

Esses objetos, muitas vezes, sintetizam as relações dos personagens, como por exemplo, a taça de Mecha ou a panela de pressão da Tali.

Se por um lado, constatamos a presença de uma ligação espaço-temporal entre os planos dado pelo som; podemos constatar também a presença de cortes secos da imagem, que agem como um choque, interrompem a ação e ressaltam uma tensão narrativa. 


\section{9:40 - 13:00 - Apresentação da casa de Tali}

Sobre a impressão de camadas sonoras (impressão de profundidade), panela de pressão e corpo multifocado. Tali faz (e escuta) muitas coisas ao mesmo tempo: conversa ao telefone, cuida dos filhos, faz almoço, procura as chaves. Existe ainda nesse trecho, uma inversão de lógica da montagem sonora: se na primeira seqüência tínhamos uma imagem que era cortada no meio da ação, restando somente o som; nessa cena, ouvimos primeiro os sons para depois vermos ou não as imagens. Por exemplo: escutamos o som do latido do cachorro, mas não o vemos (ouve-se um ruído de onde não se pode ver a fonte - que persiste até o final do filme, assim como algumas vozes de personagens que são ouvidos antes de serem vistos na cena).

\section{5:50 - 16:47 - Imagem da Santa - entrecruzamento de narrativas}

Esta cena inicia-se com um corte seco, no qual vemos uma imagem de TV que preenche toda a imagem da tela de cinema. A história da santa é apresentada como um espetáculo pelo telejornal. Esse plano é interrompido pelo toque do telefone e vemos que Momi e Isabel estão no quarto, deitadas na cama e assistindo TV.

Nessa cena também temos, além da apresentação da história da Santa, outro personagem em cena: José conversa com Momi, a denominando de súcia, apelido que revela a relação afetuosa que persiste até o final do filme.

É possível notar um entrecruzamento de narrativas: a santa, o marasmo na frente da TV, o irmão em Buenos Aires.

\section{0:24 - 22:28 - Bexigas no vidro}

Nesta cena percebemos uma relação de cumplicidade entre as irmãs e primas, que rodeiam o corpo nu de "Perro" (índio, namorado de Isabel) para escolher uma camisa de presente para José. Há aqui certa leveza cotidiana no espaço, sem o clima de tensão que se apresentou antes no filme. Ao fundo, ouvimos uma música latina alegre, que delimita esse novo clima.

\section{5:12 - Plano Cama ENQUADRAMENTO}

Plano de Momi deitada na siesta com Isabel e a outra empregada.

27:30 - 28:40 - Apresentação da Momi Súcia (do momento que José a chama de súcia até sua entrada na pileta).

Esta cena inicia-se no interior da casa. Vemos Momi passando protetor solar no espelho, em grossas camadas, deixando-a com manchas brancas na pele. Sua imagem está bipartida pelos dois espelhos da penteadeira. Pelo reflexo do espelho, podemos ver também duas figuras deitadas na cama: Mecha e José em posições opostas. José chama Momi de súcia. Ela rouba seu tênis que estava em cima da cama e é perseguida por ele até pular na piscina suja.

Podemos constatar ainda o uso de cortes para promover uma interrupção da ação, quando Momi pula na água, e tanto os personagens da cena quanto os espectadores esperam ansiosos o seu retorno do fundo da piscina, mas ele não acontece. O som estrondoso da sua entrada brusca na água vai 
sumindo e restam somente alguns ruídos das borbulhas na água.

\section{8:40 - 29:45 - Fábula da rata-africana}

Nesta cena o elemento mais destacado é o texto, como vimos a própria cineasta falar na entrevista com o seu diretor de som. Sendo assim, Lucrecia preferiu dublar essa seqüência, escondendo a boca da personagem que fala para dar mais verossimilhança à cena.

Outro elemento interessante é a intimidade dos corpos das crianças, que estão deitadas ou jogadas muito próximas umas das outras.

$\mathrm{Na}$ ocasião da apresentação dessa decupagem, fizemos o seguinte exercício: assistimos duas vezes à cena. Na primeira nos atentamos às imagens, na segunda, ao texto. Desse modo, parece mais possível conseguir apreender a história do rato do banhado, tão importante para o desenrolar da narrativa.

\section{2:10 - 32:36 - Dois espaços delimitados pela luz e sombra}

Aqui o enfoque está na estética do plano, sobretudo no que se refere à iluminação e à profundidade do plano. Assim como nas relações entre os personagens, os espaços são recortados pela luz e sombra, fixidez e tremulação, interno e externo. Nesse exemplo, temos Mecha ao fundo, iluminada no banheiro, enquanto vemos Momi no primeiro plano, camuflada pela penumbra. Embora Momi esteja no primeiro plano, mais próxima do olhar do espectador, quem está no foco da cena é mecha. A disposição dos espaços aponta para uma metáfora da relação conflituosa e de espelhamento entre mãe e filha. Momi está no espaço "entre" a infância e a idade adulta, na transitoriedade das experiências, no estado da mudança constante. Representa a vontade de escapar, ir para fora, ainda quando está dentro. No final do filme, mesmo permanecendo em La Mandrágora, deitada nas cadeiras ao lado da piscina, junto com Véro e reproduzindo o comportamento dos adultos no início do filme, é Momi quem vai buscar um milagre fora, onde apareceu a Santa, mas não vê nada e volta aos domínios da sua casa.

\section{2:40 - 33:57 - Cena da Vaca no pântano}

Aqui, Luchi enfrenta a morte pela primeira vez. Depois se seguirão mais duas outras mortes - a da brincadeira das crianças e a do final do filme.

Podemos notar o uso de dois procedimentos cinematográficos comuns para ressaltar a tensão: o campo/contracampo que é finalizado com o som de um tiro, cuja imagem não será vista pelo espectador. A interrupção da ação nos remete novamente ao blind spot.

Nesse ponto do filme, notamos mais uma vez a apresentação do ciclo dos três espaços circunscritos no filme: a floresta, a pileta e o interior da casa (do mais distante para o mais próximo).

\section{6:55 - 39:30 - Momento de sublimação - Dança no quarto de Mecha}

Nesta cena, que inicia-se com uma conversa entre Tali e Mecha, temos Mariana (a filha mais nova de Tali) observando todo o diálogo. Aos poucos, no decorrer da conversa, temos 3 espaços que são subentendidos: os meninos brincam no pântano, as meninas chegam da pileta e todos se reúnem no quarto de Mecha (com exceção dos garotos).

A cama de Mecha se torna o ponto de encontro na casa, e ao fundo vemos José no banheiro secando os cabelos, reproduzindo uma ação apresentada por seu pai. Na conversa, temos duas narrativas que 
já nos foram apresentadas: a conversa sobre a viagem à Bolívia (apresentada na primeira cena de Tali ao telefone) e a ida à caixa d'água para ver a Virgem Santa.

A mudança de tom é marcada pela interferência dos objetos na cena: a conversa intimista entre Mecha e Tali, no ambiente escuro e silencioso, somada à presença dos trovões e dos sons da taça de vinho, é interrompida pelo abajur de Mecha, que é ligado por Mariana e o toca-fitas de Véro, dando prosseguimento à brincadeira de José com o secador. Passamos então para outro estado, mais iluminado, vivaz e agitado, um momento de sublimação. O secador marca a presença masculina, e é essa presença que puxa as garotas para dançar. Esse é um raro momento feliz e leve do filme.

Nessa cena, podemos notar que Mecha e Momi são as únicas que não participam da dança. Momi revela o medo que assombra Mecha: acabar presa na cama, assim como a sua mãe, a avó de Momi. Para revidar, Mecha a chama de imunda e ordena que vá tomar banho.

\section{0:18 - 42:14 - Interna - Casa da Tali (Conversas entrecruzadas)}

Nesta cena, a câmera está fixa e ouvimos um ruído que perturba o diálogo principal do casal (Tali e Rafael). Além dessa presença ruidosa do som - uma dança africana na TV - também ouvimos uma conversa entrecruzada entre o Rafael e Luchi, que pergunta ao pai se existem ratas-africanas. No final dessa cena, temos um momento de retirada de Tali, que se ausenta da sala em direção ao fundo da casa, no quintal, para fumar escondida dos filhos e do marido. A cena é interrompida pelo latido do cachorro.

Nessa cena, Tali repete uma frase que retomará algumas vezes ao longo do filme: "es siempre lo mismo", quando este fala que ela não deveria viajar sozinha com Mecha.

\section{5:49 - Corpos na cama - ENQUADRAMENTO}

Momento de silêncio, com uma "quase" retirada total de som ambiente.

\section{7:10 - 47:58 - Interna quarto José - La Mandrágora}

Véro e Agustina (filha mais velha de Rafael e Tali) tiram a roupa de José. Os três estão na cama, há um ar de sensualidade e intimidade. Véro observa Agustina despindo o irmão.

\section{8:00 - 49:00 - Interna trabalho Rafael}

As cenas com as questões de Luchi começam a ficar ruidosas. Nessa cena, Tali vai ao trabalho de Rafael mostrar as radiografias de Luchi, com a boca cheia de dente. Durante todo o diálogo temos interrupções ruidosas e luminosas no diálogo, ao que parece, trata-se de uma solda. Luchi tenta perguntar novamente sobre a rata-africana, mas ninguém o ouve.

Aqui, podemos ver uma referência às arcadas dos gatos dentro da rata-africana.

\section{9:41 - 51:30 - Interna corredor de La Mandrágora}

Câmera na mão. Mecha falando ao telefone, com óculos escuros dentro da casa. Nessa cena, Mecha olha de longe para Gregório estirado na cama e murmura "es siempre lo mismo".

\section{2:00 - 53:18 - Externa Barragem - Potência da água}


Meninas na água em bóias frágeis e os meninos pescam batendo facões na água. A sequiência termina com a irrupção de toda a potência da água da barragem.

\section{6:18 - 56:10 - Externa - Quintal Tali}

A cena começa com Luchi contando e olhando para a parede, como se brincasse de escondeesconde. A cena apresenta o ponto de vista dele, o modo como olha as coisas e percebe alguns ruídos ampliados pelo seu temor do rato do banhado. O olhar de Luchi é acompanhado de um ambiente silencioso e introspectivo até a entrada de uma grande algazarra provocada por duas meninas, uma dupla do barulho. Elas brincam com a frase: "Luciano morto", justamente no local onde no final do filme ocorrerá a morte do menino. Há um contraponto entre as tomadas de Luchi, que mesmo ao brincar aceita a morte, prende a respiração e se coloca como menino-anjo e a dupla barulhenta de meninas eternamente enfeitadas para o carnaval.

\section{6:58 - 57:42 - quarto de Mecha}

Esta é cena em que Mecha encontra-se de costas, sentada em sua cama, na penumbra, assistindo ao comercial de TV da minigeladeira. A cena merece ser destacada pois o eletrodoméstico resolve o drama de Mecha e é uma metáfora importante para o desfecho dessa personagem.

\section{1:01:10 - 1:02:05}

Mais uma cena na cama, desta vez estão Véro e José sobre um colchão mole. Típica cena desses dois irmãos, cheios de afetos e proximidade física.

\section{1:03:35 - 1:04:20 - crianças dentro do carro (campo)}

Crianças são vistas dentro do porta-malas do carro. Luchi tem medo do rato do banhado e as meninas, do marido de Mecha, por pintar os cabelos. Mais uma vez, Luchi pode ser associado à fragilidade do vidro, que ao mesmo tempo em que o revela, o esconde, quando embaçado.

\section{1:06:27 - 1:07:00 - câmera dentro do carro (contracampo)}

Esta cena inverte o ponto de vista da cena da cena anterior, agora Véro e José são vistos pelas crianças de dentro do carro. Nesse plano, a câmera utiliza o vidro do carro em um superenquadramento da imagem dos dois irmãos brincando de guerrinha. Podemos considerar este, um outro jogo de dentro e fora, jogo repetido pela cineasta anteriormente (na primeira metade do filme) ao apresentar os três espaços citados.

\section{1:10:24 - 1:12:03 - banho de Véro e José}

Outra cena de cumplicidade e intimidade entre irmãos. A cineasta joga com a sensualidade da cena, mais presente nos olhos de quem observa do que na situação em si.

\section{1:15:50 - 1:17:22 - Virgem na TV}

A cena se inicia com a imagem da TV falando mais uma vez na história da Virgem. Não sabemos, ao vermos a TV, onde estamos, é o toque do telefone que precipita a casa de Mecha, pois assim que o ouvimos, sabemos que se trata de sua casa e não da casa de Tali. 


\section{1:19:30 - Isabel e Momi na cama - ENQUADRAMENTO}

Reparem na luminosidade do quarto alterado pelo movimento do espelho do guarda-roupa, ele parece propositadamente movimentado por Momi para produzir esse efeito.

\section{Seqüência final do filme: Retomada da frase "es siempre lo mismo"}

\section{1:20:46 - casa de Tali alagando com a chuva}

Exemplo de ação que acontece no espaço, a casa de Tali é alagada pela chuva. O espaço é aquele das ações lentas, a morada da tartaruga, onde mais tarde acontecerá o acidente de Luchi.

Desse ponto em diante, de acordo com Aguillar, há um "amaneiramento", uma redução de um estilo mais estridente e conflituoso no filme. Assim, a partir desse pressuposto final, podemos analisar essa cena como um esgotamento, representado pela invasão da água, do jorro, das forças incontroláveis da natureza que, até o momento, habitavam somente o espaço ao redor de $L a$ Mandrágora, e que, agora, chegam à casa de Tali.

O jogo de reflexos na imagem, produzido pela brincadeira da criança Luchi, distorce a realidade daquele espaço e inverte a lógica espacial. O quadro é recortado transversalmente ao meio e, vemos somente a parte de baixo do tronco de Tali, que esfrega (tenta secar?) os pés no pano molhado. Sobre esse plano, ouvimos as vozes das crianças.

A partir desse plano, temos uma série de primeiros planos fixos, planos e contraplanos de Luchi e da dupla Mariana e Agustina, paralelos a alguns planos de Tali, fumando escondida na penumbra. Em seguida, Luchi brinca de suspender a respiração, como se estivesse imitando a tragada produzida pela mãe no plano anterior. Mais um presságio de sua morte.

Ainda podemos notar a presença da fragmentação dos planos e de trechos recortados dos corpos (o tronco ou a mão de Tali), apresentados de forma estática e dotados de certa imobilidade. O tom é bem diferente do modo pelo qual a casa foi apresentada inicialmente no filme, sempre cheia, carregada de intensos ruídos e vozes ambientes. A casa de Tali agora parece silenciosa, imóvel, como se estivesse sendo invadida pela força externa da natureza e não pudesse mais reagir.

$\mathrm{Na}$ faixa sonora, escutamos o ruído da chuva e as vozes das crianças numa intensidade menor. O destaque está na voz de Tali (que aparece aqui gravada com o microfone mais próximo da boca) justamente para enfatizar seu diálogo com os filhos sobre a Bolívia. Esse efeito confere um clima mais intimista para a cena. Quando Tali resolve ligar para Mecha, há um corte brusco na imagem e na banda sonora.

A partir daqui, todos os conflitos apresentados ao longo do filme, começam a ser resolvidos, como por exemplo, a compra dos materiais escolares por Rafael, endossando sua reprovação à ida de Tali e Mecha à Bolívia.

\section{1:24:28 - Resolução do conflito de Isabel}

Esta cena começa (1:22:59) com a imagem de um nadador na TV, depois passa para um plano 
fechado de Mecha na cama conversando com Tali ao telefone.

A câmera permanece fixa, só se movimenta para seguir Mecha quando esta se levanta da cama, ainda no habitual registro instável (de câmera na mão) reproduzindo um leve movimento de vertigem, como se acompanhasse a bebedeira de Mecha.

No meio da cena, Isabel entra no quarto e fica na porta do banheiro, à distância de Mecha, para pedir demissão. Durante toda a cena, a faixa sonora é pontual e quase não ouvimos o som ambiente, a não ser o som das gotas da torneira e do nadador na TV.

Diferente da casa de Tali, onde a presença da água deu-se de uma vez e torrencialmente (com o alagamento do quintal), na casa de Mecha a água jorra dos ralos, da TV, da piscina e da chuva, numa constância desde o início do filme.

\section{1:26:31 - Última cena de Mecha - Resolução de seu conflito Mecha: cama-frigobar}

Aqui, vemos ao fundo do quadro, Mecha e José instalando o frigobar ao lado da cama de Mecha. O clima novamente é bem intimista, é não temos diálogo, somente uma ambiência discreta, com menos intensidade, por exemplo, no volume conferido aos sons das cigarras. Simbolicamente, essa resolução, aponta para a manutenção do conflito, ou da profecia dita por Momi (subentendida na frase "Es siempre lo mismo"), já que temos a insinuação de que Mecha restará confortavelmente, com o seu frigobar, na cama, seguindo os mesmo passos de sua mãe, que morreu depois de encarcerar-se no quarto.

\section{1:28:00 - Última cena de Tali e família - Morte de Luchi}

A redução quase total da ambiência é percebida nitidamente nesta cena, como um efeito de suspensão que foi criado ao longo da última seqüência do filme. Gradativamente, Martel reduz o espaço à esfera micro da intimidade do cotidiano, ouvimos só o movimento dos corpos.

A música ouvida na casa de Mecha pode ser ouvida do apartamento superior, como um rastro de sonoridade da casa do vizinho. A leveza da música distrai os personagens, que chamam nossa atenção, apontando para o alto, para a verticalidade da cena.

Os planos vazios que se seguem com a criança na penumbra da cozinha, iluminada apenas por alguns poucos reflexos de luz que atravessam os vidros da porta e da bancada, mantém essa sensação de suspensão. A música cessa e ouvimos somente o barulho dos movimentos de Luchi, primeiro na bicicleta e depois andando em direção à escada, de onde vêm os latidos graves e pontuais do cachorro.

Assim, a fórmula sedução (curiosidade) e perigo andam juntos será levada ao limite com a confirmação de uma tragédia já anunciada muitas vezes ao espectador.

Nos planos da morte, vemos o garoto subir a escada até quase sumir do quadro. O plano vertical novamente é apontado como limiar do perigo. Não vemos o garoto cair diretamente no chão, só conseguimos observar que escapa uma madeira da escada e o menino escorrega. Seguem-se quatro planos fixos da casa vazia: a copa, a cozinha, o corredor do banheiro e o quintal, de um ponto de vista de onde conseguimos ver Luchi estirado no chão.

\section{1:29:55 - Cenas de Vazio - Desencontros após a morte}

Neste trecho, temos quatro primeiros planos fixos das cabeças dos personagens de Véro e José segurando o telefone, mas sem falar e de Mercedes estática. No último plano, vemos Mercedes e José conversando sobre o que dizer à Tali. 
Repetição de ciclos, de motivos e de enquadramentos: a frase "es siempre lo mismo aqui" retorna como parábola do filme.

Esta cena representa o ciclo do eterno retorno, há um reforço da atmosfera de enclausuramento dos personagens e também de contaminação (dos adultos para os jovens), uma vez que Momi e Véro repetem os gestos dos amigos bêbados de Mecha e Gregório no início do filme.

Arrastando a cadeira, Momi chega ao redor da piscina onde se encontra Véro. Assim como no início do filme, a garota chora para depois contar à irmã que foi aonde a virgem aparecia, mas não viu nada.

O último plano do filme é o mesmo do começo: um plano geral da paisagem dos morros envoltos por nuvens de uma tempestade. Ouve-se um trovão grave, e ficamos com a sensação de que ali, naquele lugar, a tempestade jamais cessará. 


\section{Decupagem "La Niña Santa"}

Sequência de abertura:

Prólogo - primeiro som até a primeira imagem 0:39 até 01:53

Sobre os créditos - letrinhas coloridas que escapam de seus nomes para completar outros nomes, ouvimos uma porta rangendo e, seguida de passos apressados. Logo, ouve-se uma voz feminina cantando - "Vuestra Soy", um grupo de orações para Santa Teresa de Ávila.

A primeira imagem surge, concomitantemente, à palavra cantada, porém não sincronizada: !Mirá! La suma vileza, que ahora canta. Que quieres el señor de mí? (Veja! A extrema vileza, que hoje canta assim Que queres o senhor de mim?).

Enquanto ouvimos um "olhe!", vemos um plano médio (cintura-cabeça) de várias garotas olhando, muito sérias, para o lado esquerdo da câmera. Uma garota mais alta, se destaca no centro do plano. O próximo corte nos dá um contra-plano da cabeça da cantora, que aparece para revelar a voz que ouvimos há quase dois minutos.

\section{USO DE SONS ACUSMÁTICOS:}

Esse comando apresentado sob a primeira imagem é a anunciação de uma estrutura: neste filme é preciso olhar para descobrir como as coisas acontecem e são os sons que tem a função de indicar este caminho. Ao longo do filme, os personagens vão se guiar dentro do espaço pelos traços de sonoridade que antecipam e retomam as relações dentro da estrutura narrativa.

\section{USO DA MÚSICA:}

As músicas diegéticas cumprem a função clássica de encontrar um clima para a cena, neste caso, são usadas para afirmar as imagens (canto clássico para a música da igreja, música dançante para a cena provocativa de Helena no espelho) ou homogeneizar os espaços (ligando os espaços do bar e do salão da conferência), no caso dos overllaps musicais.

Neste sentido, em La Ciénaga, o uso da música exercia funções diversas, sendo usada tanto para afirmar um clima (momento da dança no quarto de Mecha, com a música de Jorge Cafrune "El niño y el canário"), quanto como contraponto, exercendo assim uma função de comentário irônico em relação a imagem (música alegre "Mala Mujer" - no rádio do carro depois do acidente; a repetição dessa mesma música (Mala Mujer) no momento da briga de José e Perro por causa de Isabel; e a repetição da música "El niño y el canário" nos momentos que antecedem a morte de Luchi).

Em A Menia Santa, a função de retomada de um motivo é exercida pela música de Bach tocada no Thereminvox, ou mesmo pelo som de um spray desinfetante, que insiste em se manter presente em diversas cenas dentro do Hotel. Além disso, temos a presença de outros motivos sonoros que são reiterados ao longo do filme e marcam a sonoridade de um espaço determinado, como a ambiências das vozes de crianças nos corredores - que parecem encurralar ou delimitar um espaço dentro dos corredores do hotel ou da escola; a microfonia e as taças com gelo - que demarcam o território do restaurante; o som de "sugar" que parece ser a indicação de um ponto de escuta subjetivo de Amália - em simultaneidade com o primeiro plano de orelhas; além da ambiência global da piscina, que deixo para comentar melhor depois. 


\section{Repetições de enquadramentos, gestos e temas de "La Ciénaga"}

É também, a continuação de onde buscou-se uma imagem, mas não viu-se nada! A retomada do fim de "La Ciénaga" aparece logo no início do segundo filme de Lucrecia Martel. Em "La Ciénaga", os personagens recebem avisos sonoros como os latidos do cachorro e os outros sons da tormenta: trovões, tiros, taças, mas buscam tanto ver a imagem de um milagre (mancha na caixa d'agua) que acabam não percebendo o significado desses sons.

Podemos considerar que "La Niña Santa" é um filme que começa com uma imagem, ou melhor uma missão, anunciada por sinais sonoros (ruídos misteriosos do Thereminvox ou da queda do homem nu). Amália crê naquilo que escuta, e portanto, consegue enxergar além e encontrar o seu destino, a sua missão. Tanto, que o final do filme, não é o fechamento de uma história, mas a confirmação de uma cumplicidade e confiança, já manifestada em diversos momentos do filme, entre as duas primas.

Sobre a imagem, já podemos notar a insistência do uso do primeiro plano dos rostos das personagens. O foco, em "La Niña Santa", sempre habitará esse primeiro espaço, a frente, assim o fundo sempre aparecerá desfocado, sem nenhuma profundidade de campo. Mesmo em planos gerais, Martel mantém essa regra.

A luz também exerce a função de delimitação espacial, criando zonas de claros e escuros, que revelam partes do cenário e dos corpos, mantendo o espaço geral do Hotel mais escuro, com exceção da piscina.

\section{Primeiro OLHAR de Jano para Helena}

04:12 - 06: 23 - Interna Corredor do Hotel - Enquadramento/ aparição de motivos de som ambiente: vozes de crianças ao fundo

Jano (Carlos Belloso) vê Helena (Mercedes Morán). O decote das suas costas é recortado dentro da moldura da janela. Ouve-se um vozerio de crianças no corredor, ele logo as vemos atravessando o caminho desses homens.

No plano anterior, essas mesmas vozes exercem uma função na quebra de um momento de suspensão instaurado pela música na sala de aula - são vozes das crianças na educação física que atrapalham a canção da professora, mas somem quando esta volta a cantar.

\section{4:28 - 06:22 - Interna Quarto Helena - Enquadramento/ aparição do primeiro olhar através do espelho (REFLEXO)}

Helena conversa com empregados enquanto sobe, de costas para a câmera, numa balança. A próxima imagem revela Dr. Jano olhando a imagem de Helena sobre a balança, sem revelar a sua cabeça. Logo em seguida, um empregado abre mais a porta e percebemos que Jano vê a imagem de Helena através do espelho. Podemos notar a presença de Mirta no quarto.

06:23 - 06:56 - Interna liturgia na escola - Localização espacial pelos sons/ apresentação do motivo sonoro do Theremin - tema da "VOCAÇÃO"

Cena começa com um primeiro plano dos rostos de Amália (Maria Alché) e Josefina (Juliete Zylberberg). A professora prega que a vocação é o sentido único da existência humana.

06:56 -Som do Thereminvox - sinal sonoro da vocação de Amália. (SOM que afirma a 


\section{vontade de Deus)}

No momento em que ouvimos o ruído, e todas as alunas olham em busca de sua fonte, a professora falava sobre os sinais divinos, que podem aparecer de diversas maneiras. A localização espacial dos sons é um artifício usado por Lucrecia, para chamar mais atenção para a sua narrativa sonora. Nestes planos da escola, as crianças aparecem sempre juntas, apertadas.

\section{8:21 - 10:00 - Interna Restaurante do Hotel - Mirta/Helena - Localização Espacial do Sons/ Aparição do motivo sonoro da microfonia}

Neste ambiente temos a presença de 3 sons que marcam as ações em cena. O primeiro é o ruído do salto de Helena, em destaque pelo chão de madeira e pelo tempo de duração, já que a personagem atravessa o salão calmamente.

Helena senta-se e conversa com Mirta, que conta sobre os gêmeos do seu ex-marido. Então, Helena escuta ruídos agudos, que persistem por mais 2 ou 3 vezes, até os identificarmos como gerados por uma microfonia, já que ouvimos um teste de som distante. Em seguida, ouvimos o vozerio das crianças nos corredores, que entram em movimento ascendente, se intensificam e depois perdem intensidade e volume.

10:00 - 11:48 - Externa calçada - Cena da Molestia de Jano à Amália - Revelação da fonte causal do Theremin e confirmação da vocação de Amália

\section{1:48 - 13:01 - Interna Quarto Helena - "Mergulhos na cama" - horizontalidade do espaço/altura do enquadramento - ângulo reto ou plongée - Helena/Amália}

Há ainda outra relação entre as duas: vemos Helena sempre posicionada sob a penumbra e Amália sob a claridade da janela. Jogadas na cama, as duas mantém fixas suas posições, uma regularidade na voz e no movimento, para depois, quando Amália reconhece no jornal a foto de Dr. Jano, emudece, vira de lado e sai do espectro de luz da janela, que marcava uma triângulo no sobre o seu olho. Amália assim como a mãe, cai sob a escuridão, sob a mira do desejo do outro, sob a lógica visual de dominação masculina. O último plano é um close do rosto de Amália ao som de passarinhos.

13:01 - 16:00 - Interna Pileta - Encontro entre os 3 olhares - Ponto de escuta subjetivo/Close de orelhas

Ordem Visual - Sons acusmáticos que incitam o olhar e a variação de ponto de vistas.

Amália que vê Jano e Helena.

Jano que vê Helena.

Helena que vê Amália e não sabemos se vê Jano.

Ordem Auricular - a interiorização da ordem visual que é externa (o close é da orelha, e não temos uma imagem como subjetiva de um personagem, a não ser do ponto de vista de Amália

Ponto de escuta subjetivo de Amália - Som ascendente de ruídos de insetos de uma floresta. Amália percebe o olhar de Jano para sua mãe?

Um homem fala 34 graus. Ouvimos a voz de Helena, que pergunta: O quê?

Neste momento, dr. Jano vira e olha em direção aonde está Amália, que percebe e imediatamente resolve ficar de lado e esconder o rosto. Concomitantemente, percebe-se a entrada gradativa de um som de ar sendo sugado, como o reverso de um som. Começamos a ouvir os sons de alguns insetos 
que crescem de intensidade, como as vozes proferidas por Amália na sua oração a Virgem. Os sussuros liturgicos de Amália só cessam quando passamos a acompanhar o ponto de vista do olhar de Jano para Helena, que entra na piscina.

A mudança de som subjetivo para objetivo é dermarcada pelo primeiro plano da orelha de Dr. Jano. A partir daí, acompanhamos o contra-planos de alguns detalhes do corpo de Helena, como um close da sua mão apoiada na orelha, um plano um pouco mais aberto que mostra o seu colo, depois uma parte da piscina. Do ponto de vista de Jano não vemos Amália, mesmo conseguindo enxergar um pedaço do deck aonde está deitada.

15:22 - Depois de já dois planos, onde o ponto de vista da câmera já tinha sido devolvido ao olhar de Amália, ouve-se um som sugado, o mesmo que aparece nesta cena, sempre que temos um primeiro plano de rosto (ou orelha).

Esses dois planos anteriores, dão tempo para a nossa audição perceber que o momento em que o ponto de escuta volta a retratar a audição de Amália ocorre um momento de pausa no monólogo da mãe e na histeria litúrgica da adolescente, para que possamos escutar e deduzir a partir dos sons ambientes que um homem que entra no espaço e cumprimenta Dr. Jano, confirmando assim a identidade dele para Amália.

Final da cena é com um primeiro plano da orelha de Amália, quando paramos de ouvir o seu ponto de escuta subjetivo.

A imagem da morta: Helena no final do diálogo da pileta, pergunta para a filha se ela não está cansada - “Que horas es está? Não estás morta?” não completa a frase.

\section{6:01-17:50 - Repetição "La Ciénaga" motivo: objetos - CAMA/ TV}

Intertextualidade entre a TV e a história - O som da tv é um comentário para a cena. Em volume alto, ouve-se uma garota gemendo e chamando - "Mamãe, mamãe?".

Helena levanta da cama assustada. Freddy (irmão de Helena) entra bêbado fazendo barulho e dorme na cama com Helena e Amália.

Antes de deitarem, Helena e o irmão conversam sussurando, mas ao mesmo tempo fazem muito barulho em cena - O SOM DESEQUILIBRA O GESTO, não o afirma.

\section{1:26 - Repetição gestos da Momi/Amália - Banheiro Quarto Dr. Jano/Creme de barbear}

\section{2: 25 - 23:00 - Interna Casa Avó - Entrada no espaço / Enquadramento estático/Repetição de objetos}

\section{Enquadramento:}

Câmera posicionada na altura que corta a cabeça dos personagens quando se encontram no meio do plano, quando entram para o fundo do quadro, consegue-se ver o corpo todo. A utilização de janela, portas e espelhos para produzir quadros dentro de quadro, ou criar molduras para a cena.

\section{Objetos:}

Podemos notar uma repetição no ângulo e altura do enquadramento, que assim como em "La Ciénaga" e "La Mujer Sin Cabeza", decepa a cabeça dos personagens. Também temos a presença de objetos que também são utilizados nos outros filmes como: rádios, tv, ar condicionados (quebrados no Hotel) ou ventiladores, imagens de santos (quadros e estátuas), a cama, os espelhos (em "La Niña Santa" presente em quase todas as cenas internas), além da presença de vidros embaçados - que deixam a luz entrar, mas desfocam e conferem ambiguidade à imagem. 


\section{5:38 - Interna Salão de Conferência/ Bar Restaurante - Encontro Helena e Jano - Overlap com música}

A música diegética exerce a função de ligar dois espaços: o salão e o bar do restaurante. Surge com um volume mais baixo no final do plano geral do salão, para continuar no bar, onde ainda se ouve a mesma música, só que com volume mais alto.

Enquadramento:

27:04 - Dr. Jano atravessa na frente de Helena, já que estava posicionado atrás das suas costas quando começou o diálogo. Temos um reenquadramento do plano médio de Helena, mas agora Jano fica mais afastado ainda, quase totalmente fora-do-campo de visão. Só conseguimos ver uma faixa cinza do seu paletó que invade a borda esquerda da tela.

O enquadramento não mostra Jano, não mostra o abajour (só um pequeno recorte da sua base), não mostra o bar, já que não temos profundidade de campo, mas revela Helena centralizada no plano, na mira do nosso olhar e de Jano, que está posicionado ao lado direito da câmera, vendo a parede do bar.

O contra-plano disso, mostra o campo de visão do olhar de Helena para Jano, mas ao contrário do que vimos antes, o seu rosto invade um terço da tela. Mesmo estando desfocado, temos a imagem do seu rosto e dos cabelos em destaque.

No final deste plano, ouvimos um ruído agudo contínuo no final da música, os personagens olham para o canto externo, como se olhassem em direção ao palco.

\section{7:25 - 29:32 - Fábula da Mulher Morta - Repetição da estrutura da fábula que contamina a narrativa}

As 3 garotas (Amália, Jose e outra colega da escola) estão sentadas dentro de um ônibus e vestidas de uniformes.

1 close do rosto no escuro da colega desconhecida, que conta a história.

2 contra-plano - plano médio, do rosto de Amália encostada na janela e iluminada pelo sol. (a menina está falando : "a mulher se aproximou da janela e disse um automóvel caiu...". Amália virase e esconde o rosto do sol.

3 close do rosto de Jose olhando para trás, com apenas um lado da face iluminado pelo sol.

4 volta ao plano médio do rosto de Amália, que já olha novamente em direção ao canto direito da câmera.

A menina fala "Olhem! É por aqui a ponte!". Segue-se dois cortes rápidos, na mesma posição dos planos anteriores, onde Amália e Jose viram-se e olham para a ponte da estrada. O ruído grave do asfalto muda, é mais denso, tem mais concreto e muda o som do atrito do pneu com o asfalto. $\mathrm{O}$ clima muda, a fábula invade a narrativa.

7 plano fechado do quadril de Jose, vemos as suas mãos iluminadas no reflexo do vidro da janela. 8 plano afastado que mostra elas saindo do ônibus.

\section{8:15 - 29:32 - Repetição da cena de perseguição e caça no Pântano - Ameaça/Expectativa -}

Desdobramento da fábula de uma mulher morta, de uma aparição: a história nos fala da alma de uma mulher que salva o seu bebê pedindo a ajuda a um caminhoneiro, à beira de uma ponte. A mulher parecia humana, mas desaparece misteriosamente depois de pedir ajuda para um bebê. $\mathrm{O}$ caminhoneiro depois, a reconhece morta dentro de um carro capotado na encosta da estrada, segurando um bebê vivo.

$\mathrm{O}$ susto que as meninas levam ao acreditarem na mentira de Jose se desdobra numa correria que as colocam, verdadeiramente, em frente à ameaça real: primeiro, com a eminência de um 
atropelamento, quando as garotas atravessam na frente do trator; para depois serem ameaçadas pelos tiros dos caçadores dentro da mata.

Esta sequência de perseguição dentro da mata, mantém o clima de suspense da história contada na cena anterior do ônibus. Os elementos trabalhados são os mesmo do filme anterior, a câmera na mão nesta cena reforça o clima de instabilidade e de suspense dado pela narrativa. As vozes se distanciam, ficam marcadas com uma reverberação do ambiente e ouvimos destacados os ruídos dos tiros, dos latidos e dos insetos.

\section{9:33 - 30:54 - Interna Cozinha Hotel - Decepando frangos e matando a mãe! Diálogo/Ambiência sonora da cena}

Som: Temos silêncio, só quem fala é Mirta, Helena e a sua filha. Ouve-se durante o diálogo, um bafo de conversa ao fundo, que eleva-se quando a porta é aberta. No interior da cozinha ouve-se o som das facas decepando os frangos.

Imagem: O plano aberto mostra o diálogo entre Helena e Mirta sobre os gêmeos depois da ligação da esposa do ex-marido de Helena, que ela não atende. Helena comenta sobre Dr. Jano, mas Mirta lembra-a que ele é casado.

Helena sai e a filha de Mirta que decepava os frangos caladas fala para a mãe: "mamãe, um dia ainda te mato envenenada".

Mirta responde: "nunca mais vai conseguir emprego como chef",

Filha responde: "eu não sou cozinheira mamãe, sou fisioterapeuta",

Mirta: "enxugue os seus olhos", mas a filha não chora.

\section{3:49 - 36:20 - Interna Quarto Helena - Cama/Enquadramento}

No quarto escuro de Helena, Fredito está deitado de bruços com a cabeça enfiada entre as pernas estiradas de Helena.

Close do rosto de Helena e de suas pernas.

34:45 - Repetição de gesto e som: empregada entra no quarto com spray - ouvimos o som antes e depois vemos a imagem

\section{6:48- Externa Calçada: Repetição tema Thereminvox - Amália olha à distância Dr. Jano}

\section{7:45 - 39:50 - Interna Casa de Josefina - Homem Morto - Ameaça/Suspense}

Plano médio das 3 meninas estudando sob a mesa. Ouvimos um estrondo, como a queda de algo pesado, seguido por latidos de um cão, todos olham com espanto em direção à janela. No momento do estrondo, Amália contava a Josefina que recebeu uma missão divina. Jose pergunta se Amália recebeu um sinal e ouvimos o estrondo.

O próximo plano mostra as costas das crianças em primeiro plano e, um vulto se mexe por detrás das cortinas brancas, como se fosse um fantasma. Aparece um homem nú, atônito.

Jose olha e fala: "Está morto! [Estes] são só movimentos reflexos!"

Esta cena sustenta um clima de suspense, em relação a fonte sonora estrondosa - novamente, a pergunta "o que é?" aparece como elemento de tensão da narrativa. O som acusmático aqui impõe uma pergunta que necessita de resposta - temos um acidente ou um sinal de Deus? 
A presença do morto também remete a imagem do fantasma da mulher morta, fábula apresentada dez minutos antes, ou pode ser percebida como desdobramento dessa imagem. Aquele que já está morto, mas só mantém os reflexos seria a grande metáfora deste filme?

A palavra morta ou a imagem de uma morta paralisada também foi tema de "La Ciénaga" com as três mortes do personagem Luchi. A presença do morto também servirá de elemento de tensão em "La Mujer Sin Cabeza", que no seu gestual, parece ser a encarnação, se é que podemos falar sobre isso de fantasmas, dos reflexos de uma mulher morta.

Aqui, em “La Niña Santa”, essa palavra ou presença-ausência é demonstrada em três cenas:

no final da primeira cena da piscina $(15 \mathrm{~m} 24 \mathrm{~s})$, onde Helena pergunta a Amália se "não estás morta?" - metonímia de cansaço;

na cena do ônibus $(27 \mathrm{~m} 25 \mathrm{~s})$, onde é contada a história, seguido da cena de perseguição da mata com a presença de duas ameaças à vida: com o quase-atropelamento e os tiros dos caçadores; na própria cena do homem nú;

na imagem de Helena paralisada $(39 \mathrm{~m} 38 \mathrm{~s})$ sobre a cama com Amália a observando, como se estivesse morta - o diálogo dessa cena explica a cena do homem nú, que segundo Amália foi salvo da morte por um milagre.

\section{6:46 - 47:00 - Interna Banheiro - Repetição crianças brincando com jato d'água}

\section{7:06 - 48:00 - Interna Quarto - Helena dança na frente do espelho}

\section{8:12 - 49:09 - Segunda cena da pileta - Jano olha para Helena}

Ambiência Sonora: sons reverberados, água em primeiro plano, gelo nas taças, gotas d'água. Helena nada na piscina e Jano observa.

Enquadramento cadeira lateral: Helena deitada na cadeira com toalhas na cabeça.

\section{4:02 - Externa calçada - tema do Thereminvox/Repetição da "molestia"}

Jano espiã a multidão na frente da calçada onde o música toca o Thereminvox e entra na multidão. De costas Amália pega na mão de Jano (close da mão), e ele foge.

\section{9:05 - Interna Quarto Jano - Enquadramento Cama}

Jano está largado na cama e vemos o seu reflexo no espelho.

\section{1:01:32 - 01:02:46 - Terceira cena da Piscina - Ponto de escuta subjetivo de Amália}

Amália espia Jano por entre as frestas da estrutura de um deck sob a piscina. A atmosfera sonora é estranha, temos o som ambiente da piscina com muita reverberação nas vozes, percebemos um tom mais grave, pontuados pelos ruídos de moscas, de um galo cantando ou de gotas d'água. Além disso, a presença do som da água da piscina se movimentando está em evidência, destacado em primeiro plano sonoro (muito mais próximo e bem mais alto do que as vozes), mantendo uma presença contínua ao longo da cena.

01:02:28 - Ponto de Escuta subjetivo/Encontro de olhares entre Jano e Amália/ Localização Espacial pelo som acusmático - 
Jano encontra o olhar de Amália guiado pelo som que a personagem emite ao bater a ponta dos dedos numa estrutura de metal. Vemos Amália através da fresta de um tecido de pano branco que cobre a estrutura metálica do parapeito do deck.

Entra um ruído de "sugar" (som reverso) quando Jano percebe que está sendo observado por Amália. O mesmo ruído que marcava a mudança de ponto de escuta na primeira cena na pileta. Aqui, esse ruído marca o encontro dos olhares, ou mesmo a saída de Amália, que assim que percebe ter sido vista por Jano, sai para o fundo do quadro.

01:08:00 - Interna Cama Helena - Sentada na cama, Helena pede opinião a Jano sobre qual vestido usar na representação. Depois de insistir para que Jano fique, Helena desiste de vestir o vestido, diz que não lhe caiu bem e abre a porta o encaminhando para fora do quarto.

01:09:00 - Interna Hotel - Reiteração do ruído do spray - não vemos a empregada.

\section{1:09:30 - Interna casa Josefina - Diálogo Entrecruzado/Reaparece Luchi e a frase de evitar uma desgraça}

Aqui, assim como Tali fazia, a mãe de Josefina conversa enquanto ouvimos as outras conversas das crianças.

A mãe de Jose ao reclamar sobre o comportamento das crianças conta a história dos irmãos Corrêa, que abandonaram a mãe . No momento em que a criança, que também interpretou Luchi no outro filme, entra em quadro ouvimos ao fundo a voz da mãe resmungando que os filhos só dão valor a mãe quando passam por uma desgraça.

\section{1:10:30 - Interna Corredor/Banheiro do Hotel - Segundo encontro entre Helena, Jano e Amália - Todos se conhecem/Repetição tema Theremin}

Nesta cena, onde há o encontro entre os três, é revelado a Jano a relação de mãe e filha, entre Helena, a mulher que corteja e Amália, a menina que molesta.

A cena começa com um plano escuro do corredor, com a câmera seguindo os médicos. Em silêncio, ouvem-se portas batendo e outros ruídos estranhos, até conseguirmos notar uma melodia do tema musical do Theremin. Todos param ao pé da escada no final do corredor. Olham para cima, de onde provavelmente surge o som do Theremin, agora o ouvimos com mais intensidade. É o tema do Theremin que anuncia o encontro entre Jano e Amália, com exceção dos momentos na piscina (marcados pelos sons subjetivos de Amália e pelo ambiente deliquescente).

Momento esperado, clímax do conflito: o encontro de apresentação entre os personagens, ou seja, o momento de revelação deste triângulo para Jano. Temos aqui um retorno implícito ao momento do primeiro encontro na piscina, aonde só Amália sabia para onde se direcionava o desejo e o olhar de Jano.

A partir daqui, Amália perde o controle desses olhares?

Amália deixa de ser desejável a Jano, já que ele percebe que quem controlava o espaço era ela, portanto perde o interesse pela dominação.

Mas, a perda desse desejo fica clara, em outros três momentos:

1 - quando Jano percebe que Amália espia no deck da pileta e demonstra o seu incômodo;

2 - quando Amália tenta pegar na sua mão na segunda cena da molestia e;

3 - na cena em que Amália entra no seu quarto e ele lhe dá dinheiro e a expulsa do quarto. 
Mas, que dominação é essa: em relação a Helena é visual, mas em relação a Amália era táctil, foi o toque da pele, mesmo que encoberta pelo tecido que alimentou o desejo. Na cena da molestia não temos um ponto de vista do olhar de Jano para Amália, muito ao contrário, mesmo a "encochando", Jano mantém o olhar fixo em direção ao músico.

\section{1:18:25 - 1:20:13 - Interna Lavanderia - Enquadramento / Beijo Amália e Jose - Início do desfecho}

\section{meninas cantam "Para que te quedes comigo"}

A cena começa com um enquadramento dos braços levantados de Jose, que está deitada. Vemos ao fundo toalhas dobradas e desfocadas e as pernas de Amália, tb desfocadas. Jose canta uma música (ainda guardo carícias que tú desconheces, canta a garota) e insiste para que Amália abra os olhos, mas Amália permanece imóvel e continua a letra da música cantando de olhos fechados, até que Jose lhe dá um beijo de língua.

Plongée - quase no plano horizontal do beijo das meninas.

\section{1:21:35 - Repetição do som do spray - empregada aparece ao fundo}

\section{1:26:33 - 4 Cena da Piscina - Jano e Família}

Amália vê Dr. Jano com a esposa e o filho na piscina. Jano percebe que Amália olha-o à distância.

\section{1:31:26 - Interna Quarto de Jano - Beijo de Amália e Jano}

Jano reage com repulsa ao beijo de Amália. No plano do beijo o foco está nele, e sua mão que resta sobre o rosto de Amália fica desfocada.

\section{1:32:14 - Interna Quarto Helena - Beijo Helena e Jano}

Jano reage com desejo ao beijo de Helena. Close nas faces de Jano e Helena, com os cabelos e entorno desfocado, sendo que no momento do beijo Helena está de costas.

\section{1:35:00 - Interna Salão de Conferência/Sala de Espera - Representação}

Localização espacial / overlap / montagem paralela (simultaneidade de ações usada para intensificar o clima de espera) - Microfonia na sala de conferência é adiantada no plano anterior (overlap sonoro liga o espaço da sala de conferência com a sala de espera, onde a mãe de Jose procura o ruído).

\section{1:36:00 - Ultimo olhar de Jano para Helena}

Jano olha para Helena por entre as cortinas da coxia - quadro dentro do quadro, já que a coxia impõe uma moldura para o olhar. As cores da cortina da coxia são as mesmas do vestido de Helena, que por sinal é vista de costas, remetendo ao enquadramento do primeiro olhar de Jano para Helena (enquadrado do vestido com a moldura da janela).

1:37:03 - Palmas overlap (mãe de Jose olha para cima na sala de espera)/ repetição som spray (mãe e pai de Jose olham para a esquerda, de onde vem surgir uma empregada).

1:37:28 - Final - Última cena piscina -

Silêncio/Água/Mosca 
Som forte da piscina enchendo de água.

Cheiro?

Flor de Laranjeira.

Jose fala que irá cuidar sempre de Amália como uma irmã. Nadam juntas e cantarolam uma mesma música - Plano longo em plongée - percorrem os 4 cantos da piscina até sair de quadro

$(1 \mathrm{~h} 40 \mathrm{~m})$ - Quando acaba o plano e entra a tela azul, o som de sugado aparece, mas continuamos a ouvir a ambiência geral da cena: ainda ouvimos as respirações, vozes ao fundo, os risos e o som provocado pelo movimento das meninas na água. A música do Theremin acaba com o plano sonoro assim que aparece nos créditos o nome de Lucrecia Martel. 


\section{Decupagem "La Mujer sin cabeza"}

\section{Prólogo}

O primeiro plano do filme é um travelling de três garotos correndo na beira de uma estrada. Vemos um cachorro latindo que passa pelos garotos. Quando eles diminuem o ritmo para atravessar a estrada temos um corte para um plano mais aberto, que mostra as três figuras paradas sobre a seca paisagem. Um grande pasto rasteiro e árvores secas, típicas do inverno seco na região do norte da Argentina, perto dos Andes.

Sobre este plano geral, onde a câmera está posicionada do outro lado da estrada e os garotos correm para atravessar, ouvimos 3 silvos metálicos, agudos, suaves e ritmado. As crianças se aproximam da câmera e ouvimos latidos do cachorro.

Dois pequenos planos médios se seguem para mostrar uma criança chamada Changuila resmungar para Aldo, o garoto que sobe no outdoor, pegar a sua bicicleta. Sobre o primeiro plano do garoto quando ele cessa o diálogo, ouvimos dois sopros fortes $(1 \mathrm{~m} 33 / 34 \mathrm{~s})$. O próximo plano mostra um terceiro garoto escondido entre os arbustos, com os olhos pintados como o de um índio, soprando e encarando a câmera.

Temos um primeiro procedimento de montagem de som anunciado que persistirá até o final do filme: ouvimos sons adiantados do próximo plano, sutis ou longos overlaps de diálogos ou sons.

Tempo de antecipação do fora de campo : 1 segundo

Tipo de som: sopro - fora-de-campo (evidencia um detalhe no espaço)- uma voz suave feminina. O estranhamento é do espectador, não do personagem - mostra a imagem de quem sopra, mas no plano anterior o personagem não reage ao estímulo sonoro (muito baixo).

A montagem antecipa o enunciado do próximo plano, o próximo olhar, o próximo motivo, não antes sem criar dúvida e expectativa.

Como acontece também nos outros filmes, temos uma relação de ambiguidade que pode ser evidenciada na enunciação, em menor ou maior grau de intensidade, dependendo do tempo de sustentação dessa invasão sonora do som fora-de-campo.

Ao redor do primeiro plano da face do garoto tudo está borrado, turvo, sem nitidez. A profundidade de campo que apareceu nos primeiros planos do filme, já começa a revelar o jogo entre claro e escuro, entre corpos próximos e distantes que apreciamos no plano imagético. A banda sonora, por sua vez, também se utiliza de contraposições, os sons internos do mundo, a intimidade da casa, os sussurros. Os sons dessa paisagem também são já nossos conhecidos antigos de outras películas de Lucrecia Martel, zumbidos de moscas e insetos estão presentes, assim como o silvo metálico ritmado que persiste ao longo de toda essa sequência.

No final, percebemos que Changuila não consegue sair de dentro do canal.

\section{2:23 - Externa Frente da Escola - Enquadramento no vidro do carro / repetição de enquadramento do Pântano}

No enquadramento que mostra um mulher ensinando a outra a fixar os cílios postiços, vemos pelo reflexo do vidro da janela do carro que mostra as mulheres em diagonal, e em sobreposição aos bancos do carro.

Com o plano da criança presa dentro do carro temos uma reiteração do plano em que Luchi fica preso dentro do carro com as "chicas carnavalescas". 


\section{2:47 - Enquadramento close do rosto da criança através do vidro}

Esta sequencia das mulheres na frente da escola é marcada pela falta de profundidade de campo.

Ouvimos vários trechos de conversas paralelas entre as mulheres, algumas vozes mais destacadas em relação a outras, alguém parece carregar vidros que se batem, além do vozerio de crianças brincando que atravessam o plano. O som de uma revoada de pássaros e o ruído do motor de um carro ligado.

04:24 - 04:39 Plano anterior ao atropelamento - A câmera está dentro do carro, no banco central do passageiro. Ouvimos uma música alegre no rádio "Soleil, Soleil". O telefone toca e temos um corte.

04:39 - 05:54 - Plano longo do atropelamento - Plano médio de Verônica dirigindo, a vemos do ombro para cima com a câmera posicionada agora no banco ao seu lado. O telefone persiste tocando e Verô abaixa para pegá-lo, quando ouvimos um estrondo. A imagem trepida com se tivesse sofrido um solavanco rápido, Verô levanta a cabeça desesperada e pára o carro. A música continua a tocar, e o telefone pára antes do final do plano.

05:55 - 06:07 - Plano aberto do vidro traseiro do carro mostra um cachorro morto na beira da estrada

05:59 - Cessa a música, ouvimos um click de um botão. Ficamos com os sons do motor e das molas do carro.

06:08 - 07: 45 - Volta para plano médio de Verônica dirigindo, como no momento do atropelamento.

06:50 - Verônica pára o carro e sai. Temos um leve giro da câmera para a direita, aonde vemos Verô andando na frente do carro. O enquadramento axial corta-lhe a cabeça e os pés. Ouve-se dois silvos curtos metálicos, semelhantes aos escutados nos planos de abertura, além de trovões, pássaros em revoada, cigarras, alguns carros passam ao lado.

07:19 - Chuva começa com silvos (agora mais seguidos) ao fundo.

07:45 - Tela preta com nome do filme, continua o som direto, com exceção da chuva que foi retirada no momento do corte.

\section{FINAL DO PRÓLOGO}

07:52 - 08:23 - Enquadramento/ plano médio dentro do carro. Agora Verônica está encostada no banco do passageiro, com a cabeça virada para a janela e de lateral para a câmera (mas não vemos o seu rosto, escondido pelo cabelo e pela escuridão do carro, que também revela a silueta do rosto do motorista do carro).

Do lado de fora da janela, vemos uma garota andando de moto na chuva (fundo borrado pela água no vidro). Ouvimos somente o som da moto e da chuva até (08m19s) quando entra uma voz feminina dizendo que "essa água vai ser boa para o seu cabelo".

Tempo de antecipação do fora de campo : 5 segundos

Tipo de som: Diálogo - overlap (mudança de espaço-tempo) - uma voz suave feminina

\section{8:24 - Interna corredor Hospital: Enquadramento lateral de Verô}

Podemos perceber que neste início de filme, os enquadramentos de Verô são, em sua maioria planos médios (da metade do tronco até a cabeça ou só do quadril/tronco sem a cabeça). Outra insistência é a lateralidade da sua face, como se pudessemos olhar um lado de cada vez, sem poder desvendar 
muito bem as expressões faciais da personagem.

Neste plano, vemos uma mulher (a mesma da voz que ouvimos no plano anterior) conversando com Verônica e passando a mão nos seus cabelos.

\section{9:36 - 10:08 Interna Sala de Raio X/ Corredor Hospital- Repetição enquadramento sem cabeça / Overlap sonoro -}

Plano geral da sala com o rosta da mulher sem cabeza encoberto pelo aparelho de raio x. Cenário em cor branca com a luz esverdeada. Tudo é sóbrio e frio. As roupas de Verô são os únicos elementos coloridos, uma saia em tom terra e uma blusa vinho.

Sobre a imagem entra uma voz feminina que fala: "Está dormindo esta senhora". Justificativa no próximo plano mostrando uma senhora sentada num banco ao lado de Verônica, que está dormindo

Tempo de antecipação do fora de campo : 09m36s a 09m39s -3 segundos +10 segundos $(09 \mathrm{~m} 49 \mathrm{~s}$ - ponto em que a mulher vira-se de costas para a câmera, não vemos a sua boca mexer ao ouvir essa voz, só deduzimos que a voz pertence a senhora), sendo que o outro plano começa com as pessoas imóveis e em silêncio, até que a mulher ao lado de Verônica vira-se e repete a mesma frase dita sobre o plano anterior. Em seguida, a senhora vira-se de frente para a câmera, olha para Verônica e a acorda, para evitar que o sangue não estanque.

Tipo de som: Diálogo - overlap (mudança de espaço-tempo) - uma voz suave feminina Ambiente: sala raio- $x$ - corredor

\section{3:20 - Interna Quarto Hotel - Enquadramento CAMA}

Plano aberto com a câmera na altura do ombro mostra a alguém estirado na cama, embaixo de um lençol. O quarto está na penumbra, iluminado só pela luz da janela. 
Programa da encenação teatral $¡$ Salta!. 